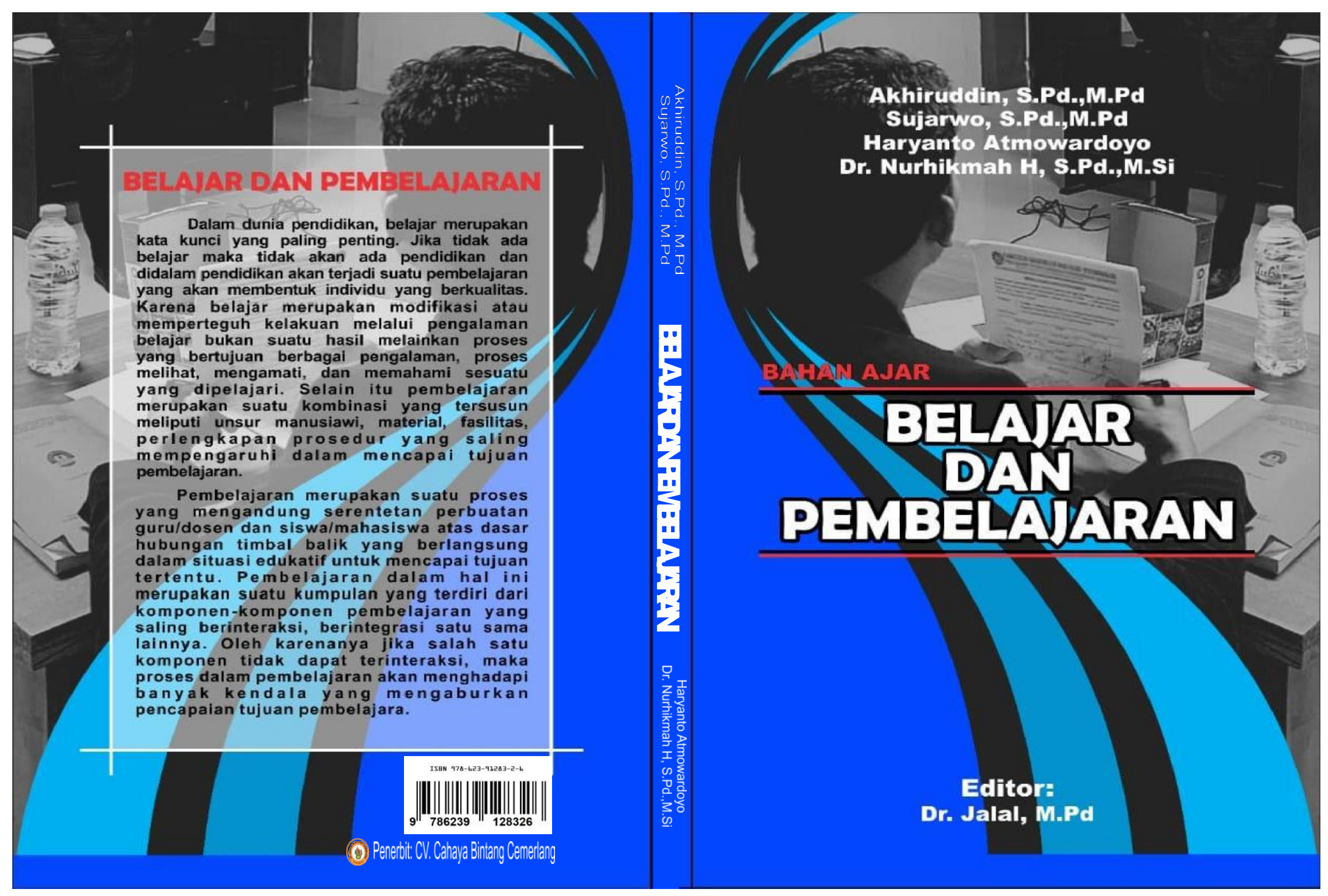




\title{
BELAJAR DAN PEMBELAJARAN
}

\section{Penulis}

\author{
Akhiruddin, S.Pd., M.Pd \\ Sujarwo, S.Pd., M.Pd \\ Haryanto Atmowardoyo \\ Dr. Nurhikmah H, S.Pd., M.Si
}

PENERBIT: CV. CAHAYA BINTANG CEMERLANG 


\section{BELAJAR DAN PEMBELAJARAN}

\section{Penulis:}

Akhiruddin, S.Pd., M.Pd

Sujarwo, S.Pd., M.Pd

Haryanto Atmowardoyo

Dr. Nurhikmah H, S.Pd., M.Si

ISBN : 978-623-91283-2-6

Editor :

Dr. Jalal, M.Pd

Penyunting:

Muh. Nur Fajrin

Putri Irmawati

Desain Sampul dan Tata Letak

Muh. Yunus Nabbi

Penerbit:

CV. CAHAYA BINTANG CEMERLANG

Redaksi :

J1. Dr.Wahidin Sudirohusodo BTN Indira Residence Blok E No. 10

Sungguminasa Kab. Gowa

No. HP: 085256649684

Email : $\underline{\text { irmamandiri7@gmail.com }}$

Distributor Tunggal

Percetakan CV. CAHAYA BINTANG CEMERLANG

Jl. Dr. Wahidin Sudirohusodo BTN Indira Residence Blok E No. 10

Sungguminasa Kab. Gowa

No. HP: 085256649684

Email : $\underline{\text { irmamandiri7@gmail.com }}$

Cetakan Pertama, Agustus 2019

Hak cipta dilindungi Undang-undang

Dilarang memperbanyak karya tulis ini dalam bentuk dan dengan cara

Apapun tanpa ijin tertulis dari Penerbit. 


\section{KATA PENGANTAR}

Puji syukur penulis panjatkan kepada Tuhan Yang Maha Esa yang telah memberikan rahmat dan karunianya, sehingga penulis dapat menyelesaikan bahan ajar ini dengan judul: "BELAJAR DAN PEMBELAJARAN". Sholawat serta salam senantiasa tercurahkan kepada junjungan alam Nabi Besar Muhammad SAW, yang atas perjuangan dan pengorbanan beliau dalam memperjuangkan islam sehingga kita bisa merasakan indahnya islam dalam kehidupan kita. Islam telah membawa kita pada suatu kebenaran yang hakiki.

Dalam penyusunan bahan ajar ini, tidak sedikit hambatan yang tim penyusun hadapi. Namun penulis menyedari bahwa kelancaran dalam penyusunan bahan ajar ini tidak lain berkat bantuan, dorongan dan bimbingan orangtua, sehingga kendala-kendala yang penulis hadapi teratasi. Semoga bahan ajar ini dapat memberikan wawasan yang lebih luas dan menjadi sumbangan pemikiran kepada pembaca, khususnya para mahasiswa Universitas Megarezky.

Akhirnya penulis menyadari bahwa banyak terdapat kekurangan-kekurangan dalam penulisan bahan ajar ini dengan judul "Belajar \& Pembelajaran", maka dari itu penulis mengharapkan kritik dan saran yang konstruktif dari para pembaca demi kesempurnaan buku ini. Akhir kata penulis berharap agar bahan ajar ini bermanfaat bagi semua pembaca khususnya para mahasiswa sebagai bahan kuliah. Dan penulis juga berharap semoga apa kita semua lakukan bisa bernilai ibadah disisi Allah SWT. Amin.

Makassar, 27 Agustus 2019

Penulis 


\section{DAFTAR ISI}

HALAMAN SAMPUL

KATA PENGANTAR

DAFTAR ISI ii iV

BAB 1 PENDAHULUAN.

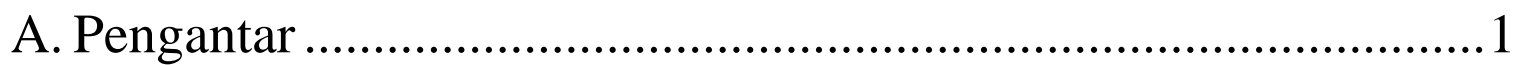

B. Penyajian Materi......................................................................2

C. Deskripsi Singkat Materi ....................................................... 7

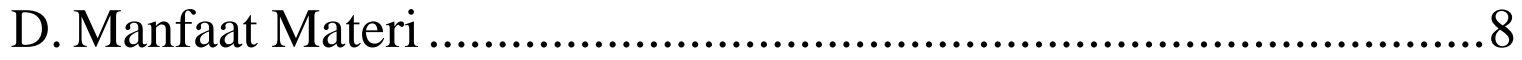

E. Peta Konsep Perkuliahan........................................................ 8

BAB II HAKIKAT BELAJAR DAN PEMBELAJARAN .............9

A. Hakikat Belajar ..................................................................... 10

B. Hakikat Pembelajaran........................................................... 13

C. Tujuan Belajar dan Pembelajaran ............................................ 14

D. Ciri-ciri Belajar dan Pembelajaran ........................................... 17

E. Perbedaan Pembelajaran, Pengajaran, Pemelajar, dan

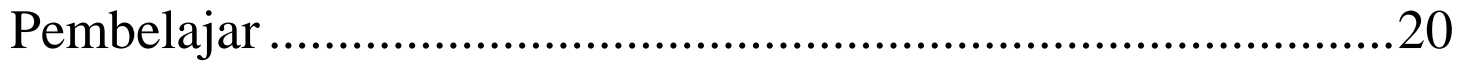

\section{BAB III PRINSIP-PRINSIP BELAJAR DAN}

PEMBELAJARAN................................................................ 21

A. Prinsip-Prinsip Belajar .........................................................21

B. Prinsip-prinsip Pembelajaran ...............................................23

C. Implikasi Prinsip Belajar dan Pembelajaran Bagi Mahasiswa/Peserta Didik .....................................................28

D. Implikasi Prinsip-prinsip Belajar dan Pembelajaran Bagi Dosen/Guru ........................................................................... 32

\section{BAB IV KOMPONEN-KOMPONEN PEMBELAJARAN ..........38}
A. Tujuan Pembelajaran .38
B. Materi Pembelajaran 40
C. Metode 46
D. Alat .51
E. Sumber Belajar .54
F. Evaluasi .55 
BAB V TEORI-TEORI BELAJAR DAN PEMBELAJARAN ...57
A. Teori Deskriptif dan Prespektif. .57
B. Teori Belajar dan Behavioristik 61
C. Teori Belajar Kognitivistik .68
D. Teori Belajar Humanistic 73
E. Teori Belajar Konstrukvistik. .74

BAB VI INTERAKSI SOSIAL DAN MOTIVASI BELAJAR ...77
A. Interaksi Sosial .77
B. Interaksi Guru dan Siswa .79
C. Pengertian Motivasi 81
D. Jenis dan Sumber Motivasi .....................................................82
E. Peran Motivasi dalam Belajar dan Pembelajaran .....................85
F. Unsur-unsur yang Mempengaruhi Motivasi Belajar.................86
G. Upaya-Upaya Memotivasi dalam Belajar ...............................8 88

BAB VII PENDEKATAN PEMBELAJARAN ................................91

A. Pendekatan, Strategi dan Metode ...........................................991

B. Jenis-jenis Metode Pembelajaran dan Penerapannya ................93

C. Pengorganisasian Peserta Didik/Mahasiswa ............................. 100

D. Pendekatan Quantum Teaching............................................101

E. Pendekatan Multiple Integences ..........................................105

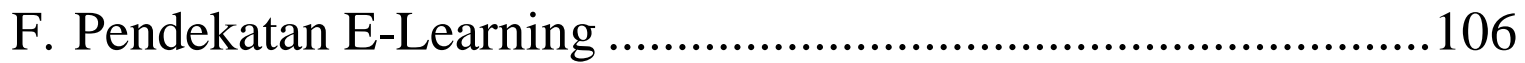

G. Pendekatan Belajar Aktif (Active Learning) .........................107

H. Pendekatan Konstektual ......................................................... 109

I. Pendekatan Belajar Berbasis Sekolah .....................................111

J. Pendekatan Belajar Kooperatif ............................................112

BAB VIII MODEL DAN METODE PEMBELAJARAN............115

A. Pengertian Model ..............................................................115

B. Model Pembelajaran..............................................................116

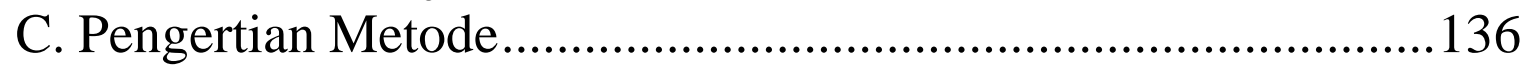

D. Metode Pembelajaran ........................................................ 137

BAB IX SUMBER BELAJAR DAN MEDIA PEMBELAJARAN

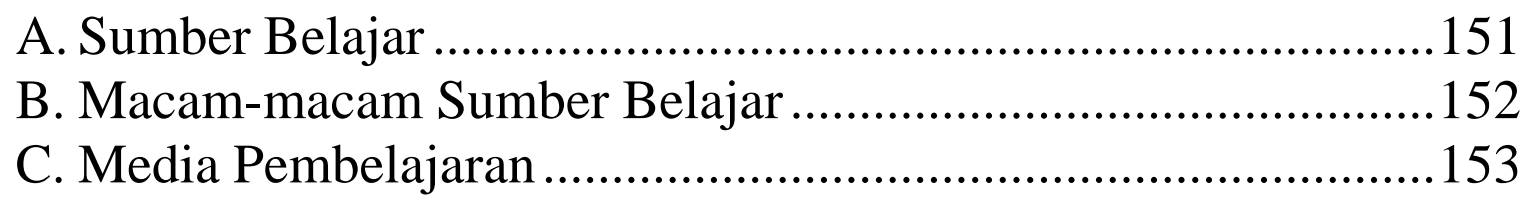



D. Macam-macam Media Pembelajaran 154
E. Pemetaan Antara Sumber Belajar, Media dan Alat Peraga .....158
F. Pemilihan dan Pemberdayaan Sumber Belajar, Media dan Alat Peraga .....

BAB X KURIKULUM PENDIDIKAN ..........................................165
A. Pengertain Kurikulum 165
B. Komponen Kurikulum. 167
C. Prinsip Kurikulum 170
D. Fungsi Kurikulum. 174
E. Peranan Kurikulum 175
F. Macam-macam Kurikulum 176
G. Tujuan Kurikulum 179
H. Manfaat Kurikulum 182

\section{BAB XI KONDISI MASALAH BELAJAR DAN}

PEMBELAJARAN .........................................................................183

A. Pengertian Masalah ..........................................................183

B. Jenis-jenis Masalah Belajar .................................................183

C. Faktor-faktor Penyebab Timbulnya Masalah Belajar ..............185

D. Faktor-faktor Penyebab Munculnya Masalah-masalah dalam Pembelajaran ....................................................................... 187

E. Masalah-masalah dalam Pembelajaran ................................189

F. Upaya Pengentasan Masalah Belajar ....................................192

G. Upaya Mengatasi Masalah-masalah dalam Pembelajaran .......194

\section{BAB XII KONSEP DASAR EVALUASI BELAJAR DAN} PEMBELAJARAN ...........................................................................197

A. Pengertian, Kedudukan \& Syarat-syarat Umum Evaluasi .......198

B. Fungsi, Tujuan dan Sasaran Evaluasi Hasil Belajar ................204

C. Prosedur Evaluasi Hasil Belajar .............................................209

D. Fungsi, Tujuan dan Sasaran Evaluasi Pembelajaran...............215

E. Prosedur Evaluasi Pembelajaran .........................................218

DAFTAR PUSTAKA ….............................................................................222 BIODATA PENULIS 


\section{BAB I \\ PENDAHULUAN}

\section{A. PENGANTAR}

Di era digital yang serba modern menuntut setiap negara untuk menghasilkan sumber daya manusia dengan kesiapan yang lebih matang dalam segala hal. Bidang pendidikan merupakan salah satu bidang yang sangat berpengaruh untuk mempersiapkan sumber daya manusia yang dibutuhkan untuk menghadapi tuntutan zaman. Namun, mendidik anak sejak dini hingga menjadi individu yang berkualitas, dan mempertahankan kualitas tersebut bukan hal yang mudah. Perlu proses yang panjang untuk membentuk individu yang mampu mengikuti alur era digital. Untuk mewujudkan hal tersebut, tentu individu harus melakukan suatu proses yang disebut belajar.

Dalam dunia pendidikan, belajar merupakan kata kunci yang paling penting. Jika tidak ada belajar maka tidak akan ada pendidikan dan didalam pendidikan akan terjadi suatu pembelajaran yang akan membentuk individu yang berkualitas. Karena belajar merupakan modifikasi atau memperteguh kelakuan melalui pengalaman belajar bukan suatu hasil melainkan proses yang bertujuan berbagai pengalaman, proses melihat, mengamati, dan memahami sesuatu yang dipelajari. Selain itu pembelajaran merupakan suatu kombinasi yang tersusun meliputi unsur manusiawi, material, fasilitas, perlengkapan prosedur yang saling mempengaruhi dalam mencapai tujuan pembelajaran

Pembelajaran merupakan suatu proses yang mengandung serentetan perbuatan guru/dosen dan siswa/mahasiswa atas dasar hubungan timbal balik yang berlangsung dalam situasi edukatif untuk mencapai tujuan tertentu. Pembelajaran dalam hal ini merupakan suatu kumpulan yang terdiri dari komponen-komponen pembelajaran yang saling berinteraksi, berintegrasi satu sama lainnya. Oleh karenanya jika salah satu komponen tidak dapat terinteraksi, maka 
proses dalam pembelajaran akan menghadapi banyak kendala yang mengaburkan pencapaian tujuan pembelajaran.

\section{B. PENYAJIAN MATERI}

\section{Konsep Belajar}

Pada dasarnya belajar merupakan tahapan perubahan prilaku siswa yang relatif positif dan mantap sebagai hasil interaksi dengan lingkungan yang melibatkan proses kognitif (syah, 2003), dengan kata lain belajar merupakan kegiatan berproses yang terdiri dari beberapa tahap. Tahapan dalam belajar tergantung pada fase-fase belajar, dan salah satu tahapannya adalah yang dikemukakan oleh witting yaitu :

a. Tahap acquisition, yaitu tahapan perolehan informasi;

b. Tahap storage, yaitu tahapan penyimpanan informasi;

c. Tahap retrieval, yaitu tahapan pendekatan kembali informasi (Syah, 2003).

Definisi yang lain menyebutkan bahwa belajar adalah sebuah proses yang dilakukan oleh individu untuk memperoleh sebuah perubahan tingkah laku yang menetap, baik yang dapat diamati maupun yang tidak dapat diamati secara langsung, yang terjadi sebagai suatu hasil latihan atau pengalaman dalam interaksinya dengan lingkungan (Roziqin, 2007: 62).

Dari berbagai definisi para ahli di atas, dapat disimpulkan adanya beberapa ciri belajar, yaitu:

a) Belajar ditandai dengan perubahan tingkah laku (change behavior).

b) Perubahan perilaku relative permanent. Ini berarti, bahwa perubahan tingkah laku yang terjadi karena belajar untuk waktu tertentu akan tetap atau tidak berubah-ubah.

c) Perubahan tingkah laku tidak harus segera dapat diamati pada saat proses belajar sedang berlangsung, perubahan perilaku tersebut bersifat potensial

d) Perubahan tingkah laku merupakan hasillatihan atau pengalaman

e) Pengalaman atau latihan itu dapat memberi penguatan. 
Di dalam tugas melaksanakan proses belajar mengajar, seorang guru perlu memperhatikan beberapa prinsip belajar berikut:

a) Apa pun yang dipelajari siswa, dialah yang harus belajar bukan orang lain.

b) Setiap siswa belajar sesuai dengan tingkat kemampuannya

c) Siswa akan dapat belajar dengan baik bila mendapat penguatan langsung pada setiap langkah yang dilakukan selama proses belajar.

d) Penguasaan yang sempurna dari setiap langkah yang dilakukan siswa akan membuat proses belajar lebih berarti.

e) Motivasi belajar siswa akan lebih meningkat apabila ia diberikan tanggung jawab dan kepercayaan penuh atas belajarnya.

Dari beberapa pengertian belajar tersebut diatas, kata kunci dari belajar adalah perubahan perilaku. Dalam hal ini, Benyamin S. Bloom (1956) mengemukakan perubahan perilaku yang terjadi sebagai hasil belajar meliputi perubahan dalam kawasan (domain) kognitif, afektif dan psikomotor, beserta tingkatan aspek-aspeknya.

a) Cognitive Domain (Kawasan Kognitif). Adalah kawasan yang berkaitan dengan aspek-aspek intelektual atau secara logis yang bias diukur dengan pikiran atau nalar. Kawasan ini tediri dari: (1)
Pengetahuan
(Knowledge),
(2) Pemahaman

(Comprehension), (3) Penerapan (Aplication), (4) Penguraian (Analysis), (5) Memadukan (Synthesis) dan (6) Penilaian (Evaluation).

b) Affective Domain (Kawasan afektif). Adalah kawasan yang berkaitan dengan aspek-aspek emosional, seperti perasaan, minat, sikap, kepatuhan terhadap moral dan sebagainya. Kawasan ini terdiri dari: (1) Penerimaan (receiving/attending),

(2) Sambutan (responding), (3) Penilaian (valuing), (4) Pengorganisasian (organization), dan (5) Karakterisasi (characterization) 
c) Psychomotor Domain (Kawasan psikomotorik). Adalah kawasan yang berkaitan dengan aspek-aspek keterampilan yang melibatkan fungsi sistem syaraf dan otot (neuronmuscular system) dan fungsi psikis. Kawasan ini terdiri dari: (1) Kesiapan (set), (2) Meniru (imitation), (3) Membiasakan (habitual) dan (4) Adaptasi (adaption)

Selanjutntya, Moh. Surya (1997) mengemukakan bahwa hasil belajar akan tampak dalam :

a) Kebiasaan; seperti : peserta didik belajar bahasa berkali-kali menghindari kecenderungan penggunaan kata atau struktur yang keliru, sehingga akhirnya ia terbiasa dengan penggunaan bahasa secara baik dan benar.

b) Keterampilan; seperti : menulis dan berolah raga yang meskipun sifatnya motorik, keterampilan-keterampilan itu memerlukan koordinasi gerak yang teliti dan kesadaran yang tinggi.

c) Pengamatan; yakni proses menerima, menafsirkan, dan memberi arti rangsangan yang masuk melalui indera-indera secara obyektif sehingga peserta didik mampu mencapai pengertian yang benar.

d) Berfikir asosiatif; yakni berfikir dengan cara mengasosiasikan sesuatu dengan lainnya dengan menggunakan daya ingat.

e) Berfikir rasional dan kritis yakni menggunakan prinsip-prinsip dan dasardasar pengertian dalam menjawab pertanyaan kritis seperti "bagaimana" (how) dan "mengapa" (why).

f) Sikap yakni kecenderungan yang relatif menetap untuk bereaksi dengan cara baik atau buruk terhadap orang atau barang tertentu sesuai dengan pengetahuan dan keyakinan.

g) Inhibisi (menghindari hal yang mubazir).

h) Apresiasi (menghargai karya-karya bermutu.

i) Perilaku afektif yakni perilaku yang bersangkutan dengan perasaan takut, marah, sedih, gembira, kecewa, senang, benci, was-was dan sebagainya. 


\section{Konsep Pembelajaran}

Pembelajaran adalah suatu proses yang mengandung serentetan perbuatan guru dan siswa atas dasar hubungan timbal balik yang berlangsung dalam situasi edukatif untuk mencapai tujuan tertentu. Dalam pembelajaran terdapat sejumlah tujuan yang hendak dicapai. Pembelajaran dalam hal ini merupakan suatu kumpulan yang terdiri dari komponen-komponen pembelajaran yang saling berinteraksi, berintegrasi satu sama lainnya. Oleh karenanya jika salah satu komponen tidak dapat terinteraksi, maka proses dalam pembelajaran akan menghadapi banyak kendala yang mengaburkan pencapaian tujuan pembelajaran.

Istilah "pembelajaran" sama dengan "instruction atau "pengajaran". Pengajaran mempunyai arti cara mengajar atau mengajarkan. (Purwadinata, 1967, hal 22). Dengan demikian pengajaran diartikan sama dengan perbuatan belajar (oleh siswa) dan Mengajar (oleh guru). Kegiatan belajar mengajar adalah satu kesatuan dari dua kegiatan yang searah. Kegiatan belajar adalah kegiatan primer, sedangkan mengajar adalah kegiatan sekunder yang dimaksudkan agar terjadi kegiatan secara optimal.

Berangkat dari pengertian tersebut, maka dapat dipahami bahwa pembelajaran membutuhkan hubungan dialogis yang sungguhsungguh antara guru dan peserta didik, dimana penekanannya adalah pada proses pembelajaran oleh peserta didik (student of learning), dan bukan pengajaran oleh guru (teacher of teaching) (Suryosubroto, 1997: 34). Konsep seperti ini membawa konsekuensi kepada fokus pembelajaran yang lebih ditekankan pada keaktifan peserta didik sehingga proses yang terjadi dapat menjelaskan sejauh mana tujuantujuan pembelajaran yang telah ditetapkan dapat dicapai oleh peserta didik. Keaktifan peserta didik ini tidak hanya dituntut secara fisik saja, tetapi juga dari segi kejiwaan. Apabila hanya fisik peserta didik saja yang aktif, tetapi pikiran dan mentalnya kurang aktif, maka kemungkinan besar tujuan pembelajaran tidak tercapai. Ini sama halnya dengan peserta didik tidak belajar, karena peserta didik tidak 
merasakan perubahan di dalam dirinya (Fathurrohman \& Sutikno, 2007: 9).

Pembelajaran pada hakekatnya adalah proses interaksi antara peserta didik dengan lingkungan, sehingga terjadi perubahan perilaku kearah yang lebih baik. Dan tugas guru adalah mengkoordinasikan lingkungan agar menunjang terjadinya perubahan perilaku bagi peserta didik. Pembelajaran juga dapat diartikan sebagai usaha sadar pendidik untuk membantu peserta didik agar mereka dapat belajar sesuai dengan kebutuhan dan minatnya. Disini pendidik berperan sebagai fasilitator yang menyediakan fasilitas dan menciptakan situasi yang mendukung peningkatan kemampuan belajar peserta didik. Fungsi-fungsi pembelajaran yaitu sebagai berikut:

a) Pembelajaran sebagai sistem

Pembelajaran sebagai sistem terdiri dari sejumlah komponen yang terorganisir antara lain tujuan pembelajaran, materi pembelajaran, strategi dan metode pembelajaran, media pembelajaran/alat peraga , pengorganisasian kelas, evaluasi pembelajaran, dan tindak lanjut pembelajaran (remedial dan pengayaan).

b) Pembelajaran sebagai proses

Pembelajaran sebagai proses merupakan rangkaian upaya atau kegiatan guru dalam rangka membuat siswa belajar

c) Persiapan,

Merencanakan program pengajaran tahunan, semester, dan penyusunan persiapan mengajar (lesson plan) dan penyiapan perangkat kelengkapannya antara lain alat peraga, dan alat evaluasi, buku atau media cetak lainnya.

d) Melaksanakan kegiatan pembelajaran

Mengacu pada persiapan pembelajaran yang telah dibuatnya. Banyak dipengaruhi oleh pendekatan atau strategi dan metodemetode pembelajaran yang telah dipilih dan dirancang penerapannya, serta filosofi kerja dan komitmen guru , persepsi, dan sikapnya terhadap siswa; 
e) Menindaklanjuti pembelajaran yang telah dikelolanya.

Kegiatan pasca pembelajaran ini dapat berbentuk enrichment (pengayaan), dapat pula berupa pemberian layanan remedial teaching bagi siswa yang berkesulitan belajar.

\section{DISKRIPSI SINGKAT MATERI}

Pada Mata Kuliah BELAJAR DAN PEMBELAJARAN Ini terdiri dari beberapa pokok bahasan Yaitu; Hakikat Belajar dan Pembelajaran, Prinsip Belajar dan Pembelajaran, KomponenKomponen Pembelajaran, Teori-Teori Belajar dan Pembelajaran, Interaksi Sosial dan Motivasi Belajar, Pendekatan Pembelajaran, Model dan Metode Pembelajaran, Sumber Belajar dan Media Pembelajaran, Kurikulum Pendidikan, Kondisi Masalah-Masalah Belajar dan Pembelajaran Serta Konsep Dasar Evaluasi Belajar dan Pembelajaran.

\section{MANFAAT MATERI}

Materi ditujukan untuk membantu para mahasiswa mengetahui proses belajar mengajar pada mata kuliah Belajar dan Pembelajaran dalam kehidupan sehari-hari dan untuk lebih memahami dan mampu menjelaskan dalam dunia pendidikan khususnya mahasiswa Fakultas Keguruan dan Ilmu Pendidikan Universitas Megarezky.

\section{E. PETA KONSEP PERKULIAHAN}

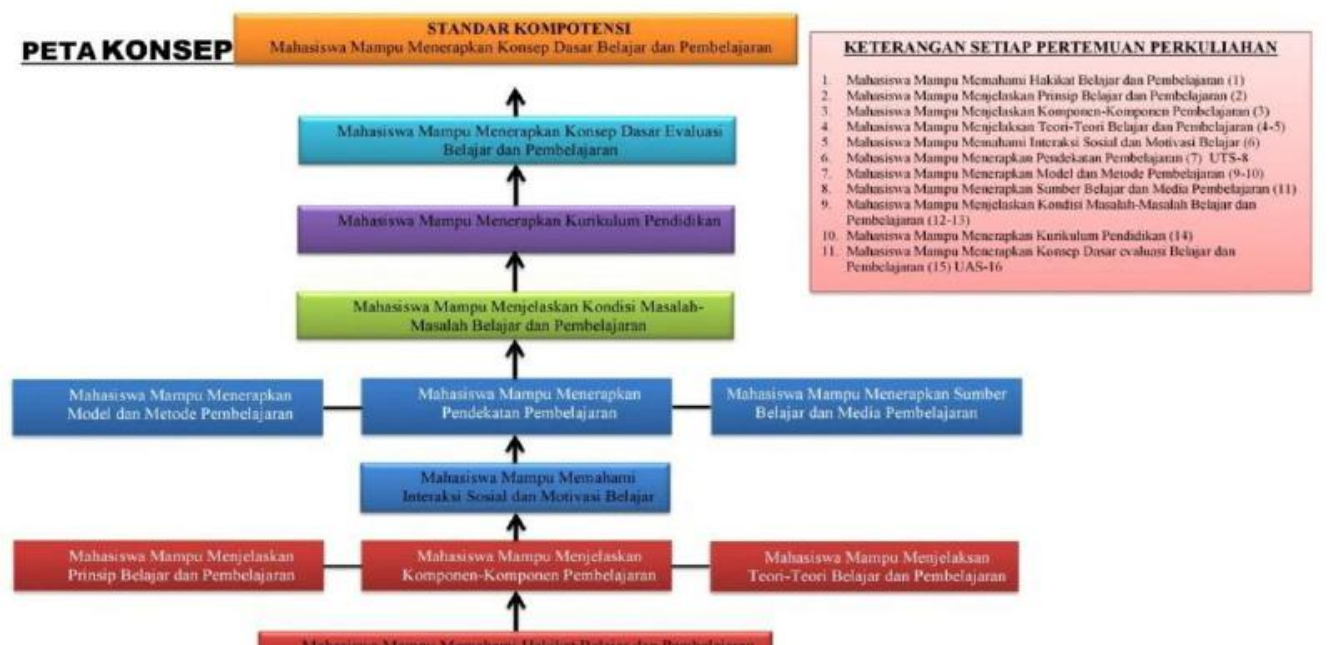




\section{BAB II}

\section{HAKIKAT BELAJAR DAN PEMBELAJARAN}

Setiap orang, baik disadari maupun tidak, selalu melaksanakan kegiatan belajar. Kegiatan harian yang dimulai dari bangun tidur sampai dengan tidur kembali akan selalu diwarnai oleh kegiatan belajar. Seseorang yang tiba-tiba melihat petani sedang mencangkul di sawah, misalnya, kemudian di dalam otaknya terlintas pikiran betapa beratnya kehidupan petani dalam menghasilkan bahan makanan, sehingga muncul perasaan menghargai hasil jerih payah petani. ilustrasi ini telah menunjukkan adanya pengalaman belajar dan telah menghasilkan perubahan perilaku berupa tindakan menghargai karya petani pada diri orang tersebut.

Efektivitas belajar yang dilakukan oleh mahasiswa di Perguruan Tinggi tidak semata-mata ditentukan oleh derajat pemilikan potensi peserta didik yang bersangkutan, melainkan juga lingkungan, terutama pendidik yang profesional. Ada kecenderungan bahwa sikap menyenangkan, kehangatan, persaudaraan, tidak menakutkan, dan sejenisnya dipandang sebagian orang sebagai pendidik yang baik. Pendidik yang profesional dituntut memiliki karakteristik yang lebih dari aspek-aspek tersebut, seperti kemampuan untuk menguasai bahan belajar, keterampilan peserta didik, dan evaluasi peserta didik.

Dengan demikian profesionalitas pendidik merupakan totalitas perwujudan kepribadian yang ditampilkan sehingga mampu mendorong peserta didik untuk belajar efektif. belajar merupakan proses penting bagi perubahan perilaku setiap orang, dan belajar itu mencakup segala sesuatu yang dipikirkan dan dikerjakan oleh seseorang. Belajar memegang peranan penting di dalam perkembangan, kebiasaan, sikap, keyakinan, tujuan, kepribadian, dan bahkan persepsi seseorang. Oleh karena itu, dengan menguasai konsep dasar tentang belajar, seseorang mampu memahami bahwa 
aktivitas belajar itu memegang peranan penting dalam proses psikologis untuk menghasilkan perubahan perilaku individu dalam kehidupan sehari-hari.

\section{A. HAKIKAT BELAJAR}

Secara harfiah, Belajar adalah yang tidak tahu menjadi tahu. Secara keilmuan, belajar merupakan perilaku kognitif yang memerlukan tingkat keterbukaan kondisi tertentu yang akan menghasilkan perubahan perilaku atau disposisi untuk bertindak (ditindak lanjuti). Menurut kamus bahasa Indonesia, belajar adalah berusaha memperoleh kepandaian atau ilmu, berlatih, berubah tingkah laku atau tanggapan yang disebabkan oleh pengalaman. Belajar adalah suatu proses yang berlangsung di dalam diri seseorang yang mengubah tingkah lakunya, baik tingkah laku dalam berpikir, bersikap, dan berbuat (W. Gulo, 2002: 23).

Menurut Nana Sudjana (2002), pada hakikatnya proses belajar mengajar adalah proses komunikasi. Kegiatan belajar mengajar di kelas merupakan suatu dunia komunikasi tersendiri dimana guru dan siswa bertukar pikiran untuk mengembangkan ide dan pengertian. belajar ada kaitannya dengan usaha atau rekayasa pembelajar. Dari segi siswa, belajar yang dialaminya sesuai dengan pertumbuhan jasmani dan perkembangan mental, akan menghasilkan hasil belajar sebagai hasil belajar sebagai perwujudan emansipasi siswa menuju kemandirian. Dari segi guru, kegiatan belajar siswa merupakan akibat dari tindakan pendidikan atau pembelajaran. Proses belajar siswa tersebut menghasilkan perilaku yang dikehendaki, suatu hasil belajar sebagai dampak pengajaran.

Belajar adalah suatu proses untuk memperoleh motivasi dalam pengetahuan, ketrampilan, kebiasaan dan tingkah laku. Pada dasarnya belajar merupakan tahapan perubahan prilaku siswa yang relatif positif dan mantap sebagai hasil interaksi dengan lingkungan yang melibatkan proses kognitif (Syah, 2003), dengan kata lain belajar merupakan kegiatan berproses yang terdiri dari beberapa tahap. 
Tahapan dalam belajar tergantung pada fase-fase belajar, dan salah satu tahapannya adalah yang dikemukakan oleh witting yaitu :

1. Tahap acquisition, yaitu tahapan perolehan informasi

2. Tahap storage, yaitu tahapan penyimpanan informasi

3. Tahap retrieval, yaitu tahapan pendekatan kembali informasi

Definisi yang lain menyebutkan bahwa belajar adalah sebuah proses yang dilakukan oleh individu untuk memperoleh sebuah perubahan tingkah laku yang menetap, baik yang dapat diamati maupun yang tidak dapat diamati secara langsung, yang terjadi sebagai suatu hasil latihan atau pengalaman dalam interaksinya dengan lingkungan (Roziqin, 2007: 62).

Dari berbagai definisi para ahli di atas, dapat disimpulkan adanya beberapa ciri belajar, yaitu:

1. Belajar ditandai dengan perubahan tingkah laku (change behavior).

2. Perubahan perilaku relative permanent. Ini berarti, bahwa perubahan tingkah laku yang terjadi karena belajar untuk waktu tertentu akan tetap atau tidak berubah-ubah.

3. Perubahan tingkah laku tidak harus segera dapat diamati pada saat proses belajar sedang berlangsung, perubahan perilaku tersebut bersifat potensial

4. Perubahan tingkah laku merupakan hasillatihan atau pengalaman

5. Pengalaman atau latihan itu dapat memberi penguatan.

Dari beberapa pengertian belajar tersebut diatas, kata kunci dari belajar adalah perubahan perilaku. Dalam hal ini, Benyamin S. Bloom (1956) mengemukakan perubahan perilaku yang terjadi sebagai hasil belajar meliputi perubahan dalam kawasan (domain) kognitif, afektif dan psikomotor, beserta tingkatan aspek-aspeknya.

1. Cognitive Domain (Kawasan Kognitif). Adalah kawasan yang berkaitan dengan aspek-aspek intelektual atau secara logis yang bias diukur dengan pikiran atau nalar. Kawasan ini tediri dari:

- Pengetahuan (Knowledge). 
- Pemahaman (Comprehension).

- Penerapan (Aplication)

- Penguraian (Analysis).

- Memadukan (Synthesis).

- Penilaian (Evaluation).

2. Affective Domain (Kawasan afektif). Adalah kawasan yang berkaitan dengan aspek-aspek emosional, seperti perasaan, minat, sikap, kepatuhan terhadap moral dan sebagainya. Kawasan ini terdiri dari:

- Penerimaan (receiving/attending).

- Sambutan (responding)

- Penilaian (valuing).

- Pengorganisasian (organization).

- Karakterisasi (characterization)

3. Psychomotor Domain (Kawasan psikomotorik). Adalah kawasan yang berkaitan dengan aspek-aspek keterampilan yang melibatkan fungsi sistem syaraf dan otot (neuronmuscular system) dan fungsi psikis. Kawasan ini terdiri dari:

- Kesiapan (set)

- Meniru (imitation)

- Membiasakan (habitual)

- Adaptasi (adaption)

\section{B. HAKEKAT PEMBELAJARAN}

Secara umum istilah belajar dimaknai sebagai suatu kegiatan yang mengakibatkan terjadinya perubahan tingkah laku. Dengan pengertian demikian, maka pembelajaran dapat dimaknai sebagai suatu kegiatan yang dilakukan oleh guru sedemikian rupa, sehingga tingkah laku peserta didik berubah ke arah yang lebih baik (Darsono, 2000: 24). Adapun yang dimaksud dengan proses pembelajaran adalah sarana dan cara bagaimana suatu generasi belajar, atau dengan kata lain bagaimana sarana belajar itu secara efektif digunakan. Hal ini tentu berbeda dengan proses belajar yang diartikan sebagai cara 
bagaimana para pembelajar itu memiliki dan mengakses isi pelajaran itu sendiri (Tilaar, 2002: 128).

Sedangkan menurut Duffy dan Roehler (1989). Pembelajaran adalah suatu usaha yang sengaja melibatkan dan menggunakan pengetahuan profesional yang dimiliki guru untuk mencapai tujuan kurikulum. Gagne dan Briggs (1979:3). mengartikan instruction atau pembelajaran ini adalah suatu sistem yang bertujuan untuk membantu proses belajar siswa, yang berisi serangkaian peristiwa yang dirancang, disusun sedemikian rupa untuk mempengaruhi dan mendukung terjadinya proses belajar siswa yang bersifat internal. Sedanghkan dalam Undang-Undang No. 23 Tahun 2003 Tentang SISDIKNAS Pembelajaran adalah proses interaksi peserta didik dengan pendidik dan sumber belajar pada suatu lingkungan belajar.

Berangkat dari pengertian tersebut, maka dapat dipahami bahwa pembelajaran membutuhkan hubungan dialogis yang sungguhsungguh antara guru dan peserta didik, dimana penekanannya adalah pada proses pembelajaran oleh peserta didik (student of learning), dan bukan pengajaran oleh guru (teacher of teaching) (Suryosubroto, 1997: 34). Konsep seperti ini membawa konsekuensi kepada fokus pembelajaran yang lebih ditekankan pada keaktifan peserta didik sehingga proses yang terjadi dapat menjelaskan sejauh mana tujuantujuan pembelajaran yang telah ditetapkan dapat dicapai oleh peserta didik.

Keaktifan peserta didik ini tidak hanya dituntut secara fisik saja, tetapi juga dari segi kejiwaan. Apabila hanya fisik peserta didik saja yang aktif, tetapi pikiran dan mentalnya kurang aktif, maka kemungkinan besar tujuan pembelajaran tidak tercapai. Ini sama halnya dengan peserta didik tidak belajar, karena peserta didik tidak merasakan perubahan di dalam dirinya (Fathurrohman \& Sutikno, 2007: 9).

Pembelajaran pada hakekatnya adalah proses interaksi antara peserta didik dengan lingkungan, sehingga terjadi perubahan perilaku kearah yang lebih baik. Dan tugas guru adalah mengkoordinasikan 
lingkungan agar menunjang terjadinya perubahan perilaku bagi peserta didik. Pembelajaran juga dapat diartikan sebagai usaha sadar pendidik untuk membantu peserta didik agar mereka dapat belajar sesuai dengan kebutuhan dan minatnya. Disini pendidik berperan sebagai fasilitator yang menyediakan fasilitas dan menciptakan situasi yang mendukung peningkatan kemampuan belajar peserta didik.

\section{TUJUAN BELAJAR DAN PEMBELAJARAN \\ 1. Tujuan Intruksional, Tujuan Pembelajaran, dan Tujuan Belajar}

Pendidik merumuskan tujuan instruksional umum dan tujuan instruksional khusus. Tujuan instruksional khusus (TIK) atau tujuan pembelajaran khusus (TPK) juga disebut sebagai sasaran belajar mahasiswa. Tujuan instruksional (pembelajaran) khusus (TIK/TPK) mempertimbangkan pengetahuan awal dan kebutuhan belajar mahasiswa.

Dari segi dosen tujuan instruksional dan tujuan pembelajaran merupakan pedoman tindak mengajar dengan acuan berbeda. Tujuan instruksional (umum dan khusus) dijabarkan dari kurikulum yang berlaku secara legal di Perguruan Tinggi.

Dari segi mahasiswa, sasaran belajar tersebut murupakan panduan belajar. Panduan belajar tersebut harus diikuti, sebab mengisyaratkan kriteria keberhasilan belajar. Keberhasilan belajar mahasiswa merupakan prasyarat belajar selanjutnya. Keberhasilan belajar mahasiswa berarti tercapainya tujuan belajar mahasiswa dengan demikian merupakan tercapainya tujuan instruksional dan sekaligus tujuan belajar bagi mahasiswa.

\section{Mahasiswa dan Tujuan Belajar}

Mahasiswa adalah subjek yang terlibat dalam kegiatan belajar mengajar di kampus. Dalam kegiatan tersebut mahasiswa mengalami tindak mengajar, dan merespon dengan tindak belajar. Pada umumnya semula mahasiswa belum menyadari pentingnya belajar. Berkat informasi dosen tentang sasaran belajar, maka mahasiswa mengetahui apa dan arti bahan belajar baginya. 
Mahasiswa mengalami suatu peroses belajar. Dalam proses belajar tersebut mahasiswa menggunakan kemampuan mentalnya untuk mempelajari bahan belajar. Kemampuan-kemampuan kognitif, afektif, psikomotor yang dibelajarkan dengan bahan belajar menjadi semakin rinci dan menguat. Adanya informasi tentang sasaran belajar, adanya penguatan-penguatan, adanya evaluasi dan keberhasikan belajar, menyebabkan mahasiswa semakin sadarakan kemampuan dirinya.

Maka dapat disimpulkan bahwa Tujuan Belajar adalah merubah tingkah laku dan perbuatan yang ditandai dengan kecakapan, keterampilan, kemampuan dan sikap sehingga tercapainya hasil belajar yang diharapkan.

\section{Tujuan Pembelajaran}

Tujuan pembelajaran merupakan salah satu aspek yang perlu dipertimbangkan dalam merencanakan pembelajaran. Segala kegiatan pembelajaran muaranya pada tercapainya tujuan tersebut.

Dilihat dari sejarahnya, tujuan pembelajaran pertama kali diperkenalkan oleh B. F Skinner pada tahun 1950 yang diterapkannya dalam ilmu perilaku (Behavioural science) dengan maksud untuk meningkatkan mutu pembelajaran. Kemudian diikuti oleh Robert Mager yang menulis buku yang berjudul: "Preparing Instructional Objective" pada tahun 1970 diseluruh lembaga pendidikan termasuk di Indonesia. Penuangan tujuan pembelajaran ini bukan saja memperjelas arah yang ingin dicapai dalam suatu kegiatan belajar, tetapi dari segi efisiensi diperoleh hasil belajar yang maksimal.

Banyak pengertian yang diberikan para ahli pembelajaran tentang tujuan pembelajaran, yang satu sama lain memiliki kesamaan disamping ada perbedaan sesuai dengan sudut pandangnya. Robert F. Mager (1962) misalnya memberikan pengertian tujuan pembelajaran sebagai tujuan perilaku yang hendak dicapai atau yang dapat dikerjakan oleh siswa pada kondisi dan tingkat kompetensi tertentu. Pengertian kedua dikemukakan 
oleh Edwar L. Dejnozka dan David E. Kapel (1981), juga Kemp (1977) yang memandang bahwa tujuan pembelajaran adalah suatu pernyataan yang spesifik yang dinyatakan dalam perilaku atau penampilan yang diwujudkan dalam bentuk tulisan untuk menggambarkan hasil belajar yang diharapakan. Perilaku ini dapat berupa fakta yang sama. Definisi ke tiga dikemukakan oleh Fred Percival dan Henry Ellington (1984) yakni tujuan pembelajaran adalah suatu pernyataan yang jelas dan menunjukan penampilan atau keterampilan siswa tertentu yang diharapkan dapat dicapai sebagai hasil belajar.

Dapat disimpulkan bahwa Belajar dan pembelajaran adalah dua kata yang sangat erat kaitannya dalam mendidik peserta didik agar nantinya dapat mencapai tujuan yang diharapkan.

\section{CIRI-CIRI BELAJAR DAN PEMBELAJARAN}

\section{Ciri Belajar}

Djamarah (2011: 15-17) menyatakan, jika hakekat belajar adalah peru-bahan tingkah laku, maka ada beberapa perubahan tertentu yang dimasukkan ke dalam ciri-ciri belajar.

a) Perubahan yang Terjadi Secara Sadar

Ini berarti individu yang belajar akan menyadari terjadinya perubahan ini atau sekurang-kurangnya individu merasakan telah terjadi adanya suatu perubahan dalam dirinya. Misalnya ia menyadari bahwa pengetahuannya bertambah, kecakapannya bertambah, kebiasaannya bertambah. Jadi, perubahan tingkah laku individu yang terjadi karena mabuk atau dalam keadaan tidak sadar, tidak termasuk kategori perubahan dalam pengertian belajar. Karena individu yang bersangkutan tidak menyadari akan perubahan itu.

b) Perubahan dalam Belajar Bersifat Fungsional

Sebagai hasil belajar, perubahan yang terjadi dalam individu berlangsung terus menerus dan tidak statis. Suatu perubahan yang terjadi akan menyebabkan perubahan berikutnya dan akan berguna bagi kehidupan ataupun proses belajar berikutnya. 
Misalnya, jika seorang anak belajar menulis, maka ia akan mengalami perubahan dari tidak bisa menulis menjadi dapat menulis. Perubahan itu berlangsung terus menerus hingga kecakapan menulisnya menjadi lebih baik dan sempurna. Ia dapat menulis dengan kapur, dan sebagainya. Disamping itu, dengan kecakapan menulis yang telah dimilikinya ia dapat memperoleh kecakapan-kecakapan lain. Misalnya, dapat menulis surat, menyalin catatan-catatan, mengerjakan soal-soal, dan sebagainya.

\section{c) Perubahan dalam Belajar Bersifat Positif dan Aktif}

Dalam perbuatan belajar, perubahan-perubahan itu selalu bertambah dan tertuju untuk memperoleh suatu yang lebih baik dari sebelumnya. Dengan demikian, makin banyak usaha belajar itu dilakukan, makin banyak dan makin baik perubahan yang diperoleh. Perubahan yang bersifat aktif artinya bahwa perubahan itu tidak terjadi dengan sendirinya, melainkan karena usaha individu sendiri. Misalnya, perubahan tingkah laku karena proses kematangan yang terjadi dengan sendirinya karena dorongan dari dalam, tidak termasuk perubahan dalam pengertian belajar.

\section{d) Perubahan dalam Belajar Bukan Bersifat Sementara}

Perubahan yang bersifat sementara (Temporer) yang terjadi hanya untuk beberapa saat saja, seperti keringat, keluar air mata, menangis, dan sebagainya tidak dapat digolongkan sebagai perubahan dalam pengertian belajar. Perubahan yang terjadi karena proses belajar bersifat menetap atau permanen. Ini berarti bahwa tingkah laku yang terjadi setelah belajar akan bersifat menetap. Misalnya kecakapan seorang anak dalam memainkan piano setelah belajar, tidak akan hilang, melainkan akan terus dimiliki dan bahkan makin berkembang bila terus dipergunakan atau dilatih.

e) Perubahan dalam Belajar Bertujuan dan Terarah 
Ini berarti bahwa perubahan tingkah laku itu terjadi karena ada tujuan yang akan dicapai. Perubahan terarah pada perubahan tingkah laku yang benar-benar disadari. Misalnya seseorang yang belajar mengetik, sebelumnya sudah menetapkan apa yang mungkin dapat dicapai dengan belajar mengetik, atau tingkat kecakapan mana yang dicapainya. Dengan demikian, perbuatan belajar yang dilakukan senantiasa terarah pada tingkah laku yang telah ditetapkannya.

\section{f) Perubahan Mencakup Seluruh Aspek Tingkah Laku}

Perubahan yang diperoleh individu setelah melalui suatu proses belajar meliputi perubahan keseluruhan tingkah laku. Jika seseorang belajar sesuatu, sebagai hasilnya ia akan mengalami perubahan tingkah laku secara menyeluruh dalam sikap kebiasaan, keterampilan, pengetahuan, dan sebagainya. Misalnya, jika seseorang anak telah belajar naik sepeda, maka perubahan yang paling tampak adalah dalam keterampilan naik sepeda itu. Akan tetapi, ia telah mengalami perubahanperubahan lainnya seperti pemahaman tentang cara kerja sepeda, pengetahuan tentang jenis-jenis sepeda, pengetahuan tentang alat-alat sepeda, cita-cita untuk memiliki sepeda yang lebih bagus, kebiasaan membersihkan sepeda, dan sebagainya. Jadi, aspek perubahan yang satu berhubungan erat dengan aspek lainnya.

\section{Ciri Pembelajaran}

1) Memiliki tujuan yaitu untuk membentuk peserta didik dalam suatu perkembangan tertentu.

2) Terdapat mekanisme, prosedur, langkah-langkah, metode dan teknik yang direncanakan dan didesain untuk mencapai tujuan yang telah ditetapkan.

3) Fokus materi ajar, terarah dan terencana dengan baik.

4) Adanya aktivitas peserta didik merupakan syarat mutlak bagi berlangsungnya kegiatan pembelajaran

5) Aktor pendidik yang cermat dan tepat 
6) Terdapat pola aturan yang ditaati pendidik dan peserta didik dalam proporsi masing-masing

7) Limit waktu untuk mencapai tujuan pembelajaran

8) Evaluasi, baik evaluasi proses maupun evaluasi hasil

\section{E. PERBEDAAN PEMBELAJARAN, PENGAJARAN, PEMELAJAR, DAN PEMBELAJAR}

Pembelajaran adalah separangkat tindakan yang dirancang untuk mendukung proses belajar siswa, dengan memperhitungkan kejadia-kejadian ekstrim yang berperan terhadap rangkaian kejadiankejadian intern yang berlangsung dialami siswa.

Pengajaran adalah proses, perbuatan, cara mengajar atau mengajarkan perihal mengajar, segala sesuatu mengenai mengajar, peringatan (tentang pengalaman, peristiwa yang dialami atau dilihatnya). Pengajaran adalah kegiatan yang dilakukan guru dalam menyampaikan pengetahuan kepada siswa. Pengajaran juga diartikan sebagi interaksi belajar dan mengajar. Pengajaran berlangsung sebagai suatu roses yang saling mempengaruhi antara guru dan siswa.

Pemelajar adalah orang yang melakukan pengajaran, dan sedangkan

Pembelajar adalah orang yang melakukan pembelajaran. 


\section{BAB III \\ PRINSIP BELAJAR DAN PEMBELAJARAN}

\section{A. PRINSIP-PRINSIP BELAJAR}

Menurut Hamalik (2004) William Burton seorang pakar pembelajaran di Amerika Serikat menyimpulkan uraiannya yang cukup panjang tentang prinsip-prinsip belajar, yaitu:

1. Proses belajar ialah pengalaman, berbuat, mereaksi, dan melampaui (under going).

2. Proses itu melalui bermacam-macam ragam pengalaman dan mata pelajaran-mata pelajaran (mata kuliah) yang terpusat pada suatu tujuan tertentu.

3. Pengalaman belajar secara maksimum bermakna bagi kehidupan siswa.

4. Pengalaman belajar bersumber dari kebutuhan dan tujuan siswa sendiri yang mendorong motivasi yang kontinyu.

5. Proses belajar dan hasil belajar disyarati oleh hereditas (keturunan) dan lingkungan.

6. Proses belajar dan hasil usaha belajar secara materiil dipengaruhi oleh perbedaan-perbedaan individual di kalangan siswa-siswa.

7. Proses belajar berlangsung secara efektif apabila pengalaman dan hasil-hasil yang diinginkan disesuaikan dengan kematangan siswa.

8. Proses belajar yang terbaik apabila siswa mengetahui status dan kemajuan.

9. Proses belajar merupakan kesatuan fungsional dari berbagai prosedur.

10. Hasil-hasil belajar secara fungsional bertalian satu sama lain, tetapi dapat didiskusikan secara terpisah. k. Proses belajar berlangsung secara efektif di bawah bimbingan yang merangsang dan membimbing tanpa tekanan dan paksaan. 
11. Hasil-hasil belajar adalah pola-pola perbuatan, nilai-nilai, pengertianpengertian, sikap-sikap, apresiasi, abilitas, dan keterampilan.

12. Hasil-hasil belajar diterima oleh siswa apabila memberi kepuasan pada kebutuhannya dan berguna serta bermakna baginya.

13. Hasil-hasil belajar dilengkapi dengan jalan serangkaian pengalamanpengalaman yang dapat dipersamakan dan dengan pertimbangan yang baik.

14. Hasil-hasil belajar itu lambat laun dipersatukan menjadi kepribadian dengan kecepatan yang berbeda-beda.

15. Hasil-hasil belajar yang telah dicapai adalah bersifat kompleks dan dapat berubah-ubah (adaptable), jadi tidak sederhana dan statis.

Berkaitan dengan proses pembelajaran, menurut Dimyati \& Mudjiono (2002) dan Aunurrahman (2012) guru dituntut untuk mampu mengembangkan potensi yang ada pada pada siswa secara optimal. Upaya dalam mendorong terwujudnya perkembangan siswa tidak dapat diukur dalam periode tertentu. Agar aktivitas yang dilakukan guru dalam proses pembelajaran terarah pada upaya peningkatan potensi siswa secara komprehensip, maka pembelajaran harus dikembangkan sesuai dengan prinsip-prinsip yang benar, yang bertolak dari kebutuhan internal siswa untuk belajar. Prinsip belajar menunjuk kepada hal-hal penting yang harus dilakukan guru agar terjadi proses belajar siswa sehingga proses belajar siswa sehingga proses pembelajaran yang dilakukan dapat mencapai hasil yang diharapkan. Prinsip-prinsip belajar memberikan arah tentang apa saja yang sebaiknya dilakukan oleh guru agar para siswa dapat berperan aktif di dalam proses pembelajaran.

\section{B. PRINSIP-PRINSIP PEMBELAJARAN}

Kata prinsip berasal dari bahasa latin "Asas (Kebenaran yang menjadi pokok dasar berpikir, bertindak, dan sebagainya) Dasar". Dalam bahasa Inggris, Prinsip disebut Principle yang berarti a truth 
or believe that is accepted as a base for reasoning or action. Prinsip merupakan sebuah kebenaran atau kepercayaan yang diterima sebagai dasar dalam berfikir atau bertindak.

Menurut Skinner dalam Dimyati dan Mudjiono (2009:9), belajar merupakan suatu perilaku. Pada saat orang belajar, maka responnya menjadi lebih baik. Sebaliknya, bila ia tidak belajar maka responnya menurun. Menurut Gagne dalam Dimyati dan Mudjiono (2009:10), belajar merupakan kegiatan yang kompleks. Hasil belajar berupa kapabilitas. Setelah belajar orang memiliki keterampilan, pengetahuan, sikap, dan nilai. Menurut Wingkel (1987), belajar adalah suatu aktifitas mental dan psikis dalam berinteraksi dengan lingkungan yang menghasilkan perubahan perilaku pada diri sendiri.

Pembelajaran adalah suatu aktivitas atau proses mengajar dan belajar. Aktivitas ini merupakan proses dua arah, antara pihak guru dan peserta didik. Dalam UU No.20 Tahun 2003 tentang Sistem Pendidikan Nasional menyatakan "Pembelajaran adalah proses interaksi peserta didik dengan pendidik dan sumber belajar pada suatu lingkungan belajar".

Jadi prinsip pembelajaran adalah landasan berpikir, landasan berpijak dengan harapan tujuan pembelajaran tercapai dan tumbuhnya proses pembelajaran yang dinamis dan terarah.

Dari berbagai prinsip belajar tersebut terdapat beberapa prinsip yang relatif berlaku umum. Dalam Damyati dan Mudjiono (2012:42), Prinsip-prinsip itu berkaitan dengan perhatian dan motivasi, keaktifan, keterlibatan langsung/pengalaman, pengulangan tantangan, balikan dan penguatan, serta perbedaan individu.

Adapun penjelasan tentang prinsip-prinsip pembelajaran diuraikan sebagai berikut:

\section{Perhatian dan Motivasi}

Perhatian mempunyai peranan penting dalam kegiatan belajar. Menurut Gage dan Berliner dalam Dimyati dan Mudjiono (2009:42), dari kajian teori belajar pengolahan informasi terungkap bahwa tanpa adanya perhatian tak mungkin terjadi 
belajar. Perhatian terhadap pelajaran akan timbul pada siswa apabila bahan pelajaran sesuai dengan kebutuhannya.

Disamping perhatian, motivasi mempunyai peranan penting dalam kegiatan belajar. Motivasi adalah tenaga yang menggerakkan dan mengarahkan aktivitas seseorang. Motivasi dapat dibandingkan dengan mesin dan kemudi pada mobil menurut Gage dan Berliner dalam Dimyati dan Mudjiono (2009:42). Menurut Herbert.L. Petri dalam Dimyati dan Mudjiono (2009:43), "Motivation is the concept we use when we describe the force action on or within an organism to initiate and direct behavior". Motivasi dapat merupakan tujuan dan alat dalam pembelajaran. Contoh, siswa belajar bersungguh-sungguh bukan disebabkan ingin memiliki pengetahuan yang dipelajarinya melainkan didorong oleh keinginan naik kelas atau mendapat ijazah.

\section{Keaktifan}

Belajar tidak bisa dipaksakan orang lain dan juga tidak bisa dilimpahkan kepada orang lain. Belajar hanya mungkin tejadi apabila anak aktif mengalaminya sendiri. Menurut Thorndike dalam Dimyati dan Mudjiono (2009:45) mengemukakan keaktifan siswa dalam belajar dengan hukum "Law of Exercise"nya yang menyatakan bahwa belajar memerlukan adanya latihanlatihan. Mc Keachie berkenan dengan prinsip keaktifan mengemukakan bahwa individu merupakan "Manusia belajar yang aktif selalu ingin tahu, sosial”. (Mc Keachie, 1976:230 dari Gredler MEB terjemahan Munandir, 1991:105).

Prinsip aktivitas di atas menurut pandangan psikologis bahwa segala pengetahuan harus diperoleh melalui pengamatan dan pengalaman sendiri. Jiwa memiliki energi sendiri dan dapat menjadi aktif karena didorong oleh kebutuhan-kebutuhan. Jadi, dalam pembelajaran yang mengolah dan mencerna adalah peserta didik sesuai dengan kemauan, kemampuan, bakat dan latar 
belakang masing-masing, guru hanya merangsang keaktifan peserta didik dengan menyajikan bahan pelajaran.

\section{Keterlibatan Langsung/Pengalaman}

Prinsip keterlibatan langsung merupakan hal yang penting dalam pembelajaran. Pembelajaran sebagai aktivitas mengajar dan belajar, maka guru harus terlibat langsung begitu juga peserta didik. Prinsip keterlibatan langsung ini mencakup keterlibatan langsung secara fisik maupun non fisik. Prinsip ini diarahkan agar peserta didik merasa dirinya penting dan berharga dalam kelas sehingga dia bisa menikmati jalannya pembelajaran.

Menurut Edgar Dale dalam Dimyati (2009:45), "Belajar yang baik adalah belajar dari pengalaman langsung”. Dalam belajar melalui pengalaman langsung siswa tidak sekedar mengamati secara langsung tetapi ia harus menghayati, terlibat langsung dalam perbuatan, dan bertanggung jawab terhadap hasilnya.

\section{Pengulangan}

Prinsip pembelajaran yang menekankan pentingnya pengulangan yang barangkali paling tua seperti yang dikemukakan oleh teori psikologi daya. Menurut teori ini bahwa belajar adalah melatih daya-daya yang ada pada manusia yang terdiri dari daya mengamat, menangkap, mengingat, menghayal, merasakan, berpikir dan sebagainya. Dengan mengadakan pengulangan maka daya-daya tersebut akan berkembang.

Hubungan stimulus dan respons akan bertambah erat kalau sering dipakai dan akan berkurang bahkan hilang sama sekali jika jarang atau tidak pernah digunakan. Oleh karena itu, perlu banyak latihan, pengulangan, dan pembiasaan.

\section{Tantangan}

Kuantzu dalam Azhar Arsyad mengatakan: "if you give a man fish, he will have a single meal. If you teach him how to fish he will eat all his life". Pernyataan Kuantzu ini senada dengan prinsip pembelajaran yang berupa tantangan, karena peserta didik 
tidak merasa tertantang bila hanya sekedar disuapi sehingga dirinya tinggal menelan apa yang diberikan oleh guru. Sebab, tanpa tantangan peserta didik merasa masa bodoh dan kurang kreatif sehingga tidak berkesan materi yang diterimanya.

Agar pada diri peserta didik timbul motif yang kuat untuk mengatasi hambatan dengan baik, maka materi pembelajaran juga harus menantang sehingga peserta didik bergairah untuk mengatasinya.

\section{Balikan dan Penguatan}

Prinsip pembelajaran yang berkaitan dengan balikan dan penguatan, ditekankan oleh teori operant conditioning, yaitu law of effect. Bahwa peserta didik akan belajar bersemangat apabila mengetahui dan mendapatkan hasil yang baik. Hasil yang baik akan merupakan balikan yang menyenangkan dan berpengaruh baik bagi hasil usaha belajar selanjutnya. Namun dorongan belajar tidak saja oleh penguatan yang menyenangkan atau penguatan positif, penguatan negatif pun dapat berpengaruh pada hasil belajar selanjutnya.

Apabila peserta didik memperoleh nilai yang baik dalam ulangan tentu dia akan belajar bersungguh-sungguh untuk memperoleh nilai yang lebih baik untuk selanjutnya. Karena nilai yang baik itu merupakan penguatan positif. Sebaliknya, bila peserta didik memperoleh nilai yang kurang baik tentu dia merasa takut tidak naik kelas, karena takut tidak naik kelas, dia terdorong pula untuk belajar lebih giat. Inilah yang disebut penguatan negatif yang berarti bahwa peserta didik mencoba menghindar dari peristiwa yang tidak menyenangkan.

Format sajian berupa tanya jawab, eksprimen, diskusi, metode penemuan dan sebagainya merupakan cara pembelajaran yang memungkinkan terjadinya balikan dan penguatan. Balikan yang diperoleh peserta didik setelah belajar dengan menggunakan metode-metode yang menarik akan membuat peserta didik terdorong untuk belajar lebih bersemangat. 


\section{Perbedaan Individu}

Siswa merupakan individual yang unik artinya orang satu dengan yang lain berbeda. Perbedaan itu terdapat pada karakteristik psikis, kepribadian, dan sifat lainnya. Untuk dapat memberikan bantuan agar peserta didik dapat mengikuti pembelajaran yang disajikan oleh guru, maka guru harus benarbenar dapat memahami ciri-ciri para peserta didik tersebut. Begitu pula guru harus mampu mengatur kegiatan pembelajaran, mulai dari perencanaan, proses pelaksanaan sampai pada tahap terakhir yaitu penilaian atau evaluasi, sehingga peserta didik secara total dapat mengikuti proses pembelajaran dengan baik tanpa perbedaan yang berarti walaupun dari latar belakang dan kemampuan yang berbeda-beda.

\section{IMPLIKASI PRINSIP BELAJAR DAN PEMBELAJARAN BAGI MAHASISWA/PESERTA DIDIK}

Peserta didik sebagai motor utama "primus motor" dalam kegiatan pembelajaran sehingga akan berhasil jika menyadari implikasi prinsip-prinsip pembelajaran terhadap dirinya.

\section{Perhatian dan Motivasi}

Dalam rangka pencapaian tujuan pembelajaran peserta didik dituntut untuk memberikan perhatian terhadap semua rangsangan. Adanya tuntutan tersebut seyogyanya mendorong peserta didik memiliki perhatian terhadap segala pesan yang terimanya. Pesan-pesan yang diterima dalam pembelajaran adalah yang dapat merangsang indranya.

Dengan demikian, peserta didik diharapkan selalu melatih indranya untuk memperhatikan rangsangan yang muncul dalam proses pembelajaran. Karena peningkatan minat merupakan salah satu faktor yang mempengaruhi motivasi. Sebagai contoh dalam proses pembelajaran peserta didik harus betul-betul dapat berkonsentrasi dalam mendengarkan ceramah guru, membandingkan konsep-konsep yang diterimanya, mengamati secara cermat gerakan yang dilakukan oleh guru dan sebagainya. 
Itu semua untuk membangkitkan motivasi belajarnya, karena tanpa perhatian seperti itu peserta didik tidak dapat menerima pelajaran secara maksimal.

Sedangkan implikasi prinsip motivasi bagi peserta didik adalah disadarinya oleh peserta didik bahwa motivasi belajar yang ada pada dirinya harus dibangkitkan dan dikembangkan secara terus-menerus. Hal ini dapat dicapai dengan mengetahui tujuan belajar yang hendak dicapai, termasuk menanggapi secara positif pujian atau dorongan dari orang lain.

\section{Keaktifan}

Peserta didik sebagai sentral dalam pembelajaran, maka sebagai konsekuensinya aktivitas peserta didik merupakan syarat berlangsungnya proses pembelajaran. Aktivitas peserta didik dalam hal ini baik secara fisik maupun intelektual dan emosional harus aktif. Jadi, tidak ada gunanya guru melakukan pembelajaran jika peserta didiknya pasif saja. Sebab para peserta didiklah yang belajar, maka merekalah yang harus melakukannya.

Sebagai implikasi prinsip keaktifan bagi peserta didik terbentuk perilaku-perilaku untuk mencari sumber informasi yang dibutuhkan, menganalisis hasil percobaan, ingin mengetahui segala percobaan yang dilakukan di laboratorium, membuat tugas-tugas yang diberikan oleh guru dan sebagainya. Proses selanjutnya terjalin keterlibatan langsung peserta didik dalam pembelajaran.

\section{Keterlibatan Langsung/pengalaman}

Tempat seorang peserta didik dalam kelas tidak dapat tergantikan oleh orang lain. Oleh karena itu, keterlibatan langsung peserta didik dalam proses pembelajaran mutlak adanya.

Sebagai implikasinya peserta didik dituntut untuk mengerjakan sendiri tugas belajar yang diberikan oleh gurunya. Dengan keterlibatan ini mereka akan mendapat pengalaman. 
Bentuk-bentuk perilaku yang merupakan implikasi prinsip keterlibatan langsung adalah segala kegiatan yang dilakukan di sekolah apakah itu berbentuk intrakurikuler ataukah ekstrakurikuler. Meskipun kegiatan tersebut tidak menjamin terwujudnya prinsip keaktifan pada diri peserta didik, namun dengan keterlibatan ini diharapkan dapat mewujudkan keaktifan peserta didik dalam proses pembelajaran.

\section{Pengulangan}

Menurut Davies dalam Dimyati (2009:52), penguasaan yang penuh dari setiap langkah memungkinkan belajar secara keseluruhan lebih berarti. Implikasi adanya prinsip pengulangan bagi siswa adalah kesadaran siswa untuk bersedia mengerjakan latihan-latihan yang berulang untuk satu macam permasalahan. Dengan kesadaran ini diharapkan siswa tidak merasa bosan dalam melakukan pengulangan. Misalnya menghafal unsur-unsur kimia, mengerjakan soal latihan dan sebagainya.

\section{Tantangan}

Prinsip belajar ini bersesuaian dengan pernyataan bahwa apabila siswa diberikan tanggung jawab untuk mempelajari sendiri, maka ia lebih termotivasi untuk belajar, ia akan belajar dan mengingat secara lebih baik (Davies dalam Dimyati, 2009:53).

Implikasi prinsip tantangan bagi siswa adalah tuntutan dimilikinya kesadaran pada diri siswa akan adanya kebutuhan untuk selalu memperoleh, memproses dan mengolah pesan. Selain itu, siswa juga harus memiliki keingintahuan yang besar terhadap segala permasalahan yang dihadapinya. Misalnya melakukan eksperimen, melaksanakan tugas terbimbing maupun mandiri atau mencari tahu pemecahan suatu masalah.

\section{Balikan dan Penguataan}

Siswa selalu membutuhkan kepastian dari kegiatan yang dilakukan. Dengan demikian siswa selalu memiliki pengetahuan 
tentang hasil (Knowledge of Result), yang sekaligus penguat (Reinforcement) Menurut Davies dalam Dimyati (2009:53).

Hal ini timbul karena kesadaran adanya kebutuhan untuk memperoleh balikan dan sekaligus penguatan bagi setiap kegiatan yang dilakukannya. Misalnya dengan segera mencocokan jawaban dengan kunci jawaban, menerima kenyataan terhadap skor yang dicapai, atau menerima teguran dari guru/orang tua karena hasil beajarnya jelek.

\section{Perbedaan Individu}

Setiap peserta didik mempunyai karakteristik yang berbedabeda. Adanya perbedaan ini seharusnya membuat setiap peserta didik menyadari bahwa dirinya berbeda dengan temannya, hal ini akan membantu diri peserta didik dalam menentukan cara belajarnya sendiri. Sebagai implikasi dari prinsip perbedaan individual bagi peserta didik adalah menentukan tempat duduk di kelas, menyusun jadwal belajar dan sebagainya.

\section{IMPLIKASI PRINSIP-PRINSIP BELAJAR DAN PEMBELAJARAN BAGI DOSEN/GURU}

Dosen/Guru seperti halnya peserta didik tidak terlepas dari implikasi prinsip-prinsip pembelajaran, karena guru yang merencanakan selanjutnya melaksanakan pembelajaran tersebut.

Implikasi prinsip-prinsip pembelajaran bagi dosen/guru terwujud dalam perilaku fisik dan psikis mereka. Jadi dengan adanya kesadaran guru pada prinsip-prinsip tersebut diharapkan adanya peningkatan kualitas pembelajaran yang diselenggarakan.

\section{Perhatian dan Motivasi}

Dalam merencanakan kegiatan pembelajarannya, guru sudah memikirkan perilakunya terhadap peserta didik sehingga dia dapat menarik perhatian dan motivasi peserta didik dan tidak berhenti pada rencana pembelajaranya tetapi sampai selesai menyajikan materinya.

Selain guru itu juga dapat menggunakan metode yang bervariasi, menggunakan media sesuai dengan tujuan belajar dan 
materi, guru dapat menggunakan gaya bahasa yang tidak monoton serta dapat mengemukakan pertanyaan-pertanyaan yang membimbing. Bila diperhatikan secara seksama implikasi prinsip perhatian bagi guru ini, ini sesuai dengan prinsip pembelajaran contextual teaching and learning, seperti inkuiri dan masyarakat belajar.

Adapun implikasi prinsip motivasi bagi guru tampak pada perilaku-perilaku di antaranya:

a) Memilih bahan ajar sesuai dengan minat peserta didik.

b)Menggunakan metode dan teknik mengajar yang disukai peserta didik.

c) Mengoreksi sesegera mungkin pekerjaan peserta didik dan sesegera mungkin memberitahukan hasilnya kepada peserta didik.

d)Memberikan pujian verbal atau non-verbal terhadap peserta didik yang memberi respon terhadap pertanyaan yang diberikan.

e) Memberitahukan nilai guna dari pelajaran yang sedang dipelajari peserta didik.

f) Perilaku yang merupakan implikasi prinsip perhatian dan motivasi bagi guru dapat dilihat lebih dari satu perilaku dari suatu kegiatan pembelajaran.

\section{Keaktifan}

Guru memberikan kesempatan belajar kepada peserta didik, memberikan peluang dilaksanakannya implikasi prinsip keaktifan bagi guru secara optimal. Peran guru mengorganisasikan kesempatan belajar bagi masing-masing peserta didik berarti mengubah peran guru, yaitu menjamin bahwa setiap peserta didik memperoleh pengetahuan dan keterampilan di dalam kondisi yang ada. Hal ini berarti pula bahwa kesempatan yang diberikan oleh guru akan menuntut peserta didik selalu aktif mencari, memperoleh dan mengolah bahan belajarnya. 
Untuk dapat menimbulkan keaktifan belajar pada diri peserta didik maka guru dapat melaksanakan perilaku-perilaku berikut:

a) Menggunakan multimetode dan multimedia.

b)Memberikan tugas secara individual dan kelompok.

c) Memberikan kesempatan kepada peserta didik melaksanakan eksprimen dalam kelompok kecil (beranggota tidak lebih dari 3 orang).

d) Memberikan tugas untuk membaca bahan belajar, mencatat hal-hal yang kurang jelas, serta

e) Mengadakan tanya jawab dan diskusi.

Sebenarnya terdapat berbagai macam metode atau cara yang dapat dipergunakan oleh guru untuk mengaktifkan peserta didik dalam pembelajaran. Terutama dengan memberikan tugas kelompok, diskusi, pemodelan serta demonstrasi.

\section{Keterlibatan Langsung}

Sudah dijelaskan di awal bahwa keterlibatan langsung peserta didik bukan hanya secara fisik karena itu tidak menjamin keaktifan belajar. Guru harus pandai-pandai merancang pembelajaran sedemikian rupa sehingga peserta didik dapat terlibat langsung bukan saja secara fisik tetapi juga mental emosional serta intelektual peserta didik.

Perilaku sebagai implikasi prinsip keterlibatan langsung bagi guru adalah sebagai berikut:

a) Merancang kegiatan pembelajaran yang lebih banyak pada pembelajaran individual dan kelompok kecil.

b)Mementingkan eksprimen langsung oleh peserta didik dibandingkan dengan demonstrasi.

c) Menggunakan media yang langsung digunakan oleh peserta didik.

d)Memberikan tugas kepada peserta didik untuk mempraktikkan gerakan psikomotorik yang dicontohkan.

e) Melibatkan peserta didik mencari informasi/pesan dari sumber informasi di luar kelas atau sekolah. 
f) Melibatkan peserta didik dalam merangkum atau menyimpulkan informasi pesan pembelajaran.

Selain itu, implikasi dari adanya prinsip ini bagi guru adalah kemampuan guru untuk bertindak bukan saja sebagai fasilitator, tetapi juga sebagai manajer/pengelola kegiatan yang mampu mengarahkan, membimbing dan memotivasi peserta didik ke arah tujuan pembelajaran yang telah ditetapkan.

\section{Pengulangan}

Jika guru mampu memilihkan bahan yang membutuhkan pengulangan dan yang tidak membutuhkan pengulangan maka guru telah melakukan implikasi dari prinsip pengulangan. Karena tidak semua bahan pembelajaran itu membutuhkan pengulangan. Pengulangan terutama dibutuhkan oleh bahan-bahan pembelajaran yang harus dihafalkan tanpa ada kesalahan sedikit pun, termasuk bahan yang membutuhkan latihan-latihan.

Perilaku guru yang merupakan implikasi prinsip pengulangan di antaranya adalah:

a) Merancang pelaksanaan pengulangan.

b) Mengembangkan / merumuskan soal-soal latihan.

c) Mengembangkan petunjuk kegiatan psikomotorik yang harus diulang.

d) Mengembangkan alat evaluasi kegiatan pengulangan.

e) Membuat kegiatan pengulangan yang bervariasi.

\section{Tantangan}

Tantangan sebagai salah satu prinsip pembelajaran yang dapat mengantar peserta didik mencapai tujuannya. Sehingga guru harus merancang kegiatan pembelajaran dalam bentuk kegiatan, bahan dan media yang dapat memberi tantangan kepada peserta didik untuk lebih bersemangat dengan tantangan itu.

Perilaku guru yang merupakan implikasi prinsip tantangan di antaranya adalah:

a) Merancang dan mengelola kegiatan eksperimen yang memberikan kesempatan kepada peserta didik untuk 
melakukannya secara individual atau dalam kelompok kecil (34 orang).

b)Memberikan tugas kepada peserta didik memecahkan masalah yang membutuhkan informasi dari orang lain di luar sekolah sebagai sumber informasi.

c) Menugaskan kepada peserta didik untuk menyimpulkan isi pelajaran yang selesai disajikan.

d) Mengembangkan bahan pembelajaran (teks, hand out, modul, dan lain-lain) yang memperhatikan kebutuhan peserta didik untuk mendapatkan tantangan di dalamnya, sehingga tidak harus semua pesan pembelajaran disajikan secara detail tanpa memberikan kesempatan peserta didik mencari dari sumber lain.

e) Membimbing peserta didik untuk menemukan fakta, konsep, prinsip, dan generalisasi sendiri.

f) Guru merancang dan mengelola kegiatan diskusi untuk menyelenggarakan masalah-masalah yang disajikan dalam topik diskusi.

\section{Balikan dan Penguatan}

Pemberian balikan dan penguatan dapat dengan lisan dan tulisan. Guru harus dapat menentukan momen dan cara yang tepat keduanya dapat diberikan dengan tepat sasaran.

Implikasi prinsip balikan dan penguatan bagi guru dapat berwujud perilaku-perilaku di antaranya:

a) Memberitahukan jawaban yang benar setiap kali mengajukan pertanyaan yang telah dijawab peserta didik secara benar ataupun salah.

b) Mengoreksi pembahasan pekerjaan rumah yang diberikan kepada peserta didik pada waktu yang telah ditentukan.

c) Memberikan catatan-catatan pada hasil kerja peserta didik (berupa makalah, laporan, klipping pekerjaan rumah), berdasarkan hasil koreksi guru terhadap hasil kerja pembelajaran. 
d) Memberikan lembar jawaban tes pelajaran yang telah dikoreksi oleh guru, disertai skor dan catatan-catatan bagi peserta didik.

e) Mengumumkan dan mengonfirmasikan peringkat yang diraih setiap peserta didik berdasarkan skor yang dicapai dalam tes.

f) Memberikan anggukan atau acungan jempol atau isyarat lain kepada peserta didik yang menjawab dengan benar pertanyaan yang disajikan oleh guru.

g)Memberikan hadiah/ganjaran kepada peserta didik yang berhasil menyelesaikan tugas.

\section{Perbedaan Individu}

Guru menghadapi peserta didik secara klasikal dalam kelas tentunya harus mempertimbangkan latar belakang atau karakteristik masing-masing peserta didik. Jadi, guru harus dapat melayani peserta didiknya sesuai karakteristik mereka orang per orang.

Adapun implikasi prinsip perbedaan individual bagi guru berwujud perilaku-perilaku sebagai berikut:

a) Menentukan penggunaan berbagai metode yang diharapkan dapat melayani kebutuhan peserta didik sesuai karakteristiknya.

b) Merancang pemanfaatan berbagai media dalam menyajikan pesan pembelajaran.

c) Mengenali karakteristik setiap peserta didik sehingga dapat menentukan perlakuan pembelajaran yang tepat bagi peserta didik yang bersangkutan.

d) Memberikan remediasi ataupun pertanyaan kepada peserta didik yang membutuhkan. 


\section{BAB IV \\ KOMPONEN-KOMPONEN PEMBELAJARAN}

\section{A. TUJUAN PEMBELAJARAN}

Tujuan pembelajaran adalah tercapainya perubahan perilaku atau kompetensi pada siswa setelah mengikuti kegiatan pembelajarantercapainya perubahan perilaku atau kompetensi pada siswa setelah mengikuti kegiatan pembelajaran. Tujuan tersebut dirumuskan dalam bentuk pernyataan atau deskripsi yang spesifik. Yang menarik untuk digarisbawahi yaitu dari pemikiran Kemp dan David E. Kapel bahwa perumusan tujuan pembelajaran harus diwujudkan dalam bentuk tertulis. Hal ini mengandung implikasi bahwa setiap perencanaan pembelajaran seyogyanya dibuat secara tertulis (written plan).

Upaya merumuskan tujuan pembelajaran dapat memberikan manfaat tertentu, baik bagi guru maupun siswa. Nana Syaodih Sukmadinata (2002) mengidentifikasi 4 (empat) manfaat dari tujuan pembelajaran, yaitu:

1) Memudahkan dalam mengkomunikasikan maksud kegiatan belajar mengajar kepada siswa, sehingga siswa dapat melakukan perbuatan belajarnya secara lebih mandiri;

2) Memudahkan guru memilih dan menyusun bahan ajar;

3) Membantu memudahkan guru menentukan kegiatan belajar dan media pembelajaran;

4) Memudahkan guru mengadakan penilaian.

Dalam pendekatan masalah khusus dalam pembelajaran atau sering di kenal dengan istilah SME, mendeskripsikan bahwa pendekatan ini akan menciptakan pembelajaran yang spesifik sesuai dengan bidangnya. Pendekatan ini lebih mempertimbangkan apa yang harus dipelajari tentang materi tersebut. Tidak bisa dipungkiri bahwa identifikasi tujuan pembelajaran melalui pendekatan masalah khusus dalam pembelajaran, mengandung makna sebagai pengetahuan dan pengertian berdasarkan informasi yang diterima. 
Tujuan khusus melalui pendekatan tugas akan valid jika melalui perencanaan yang tepat dan melalui latihan dengan petugas yang ahli dalam pelatihan tersebut atau jika pendesain pembelajaran dapat melatih pemahaman dan kecakapan untuk mengkonfirmasi atau mengubah tujuan pembelajaran setelah menemukan fakta. Pendekatan yang keempat yaitu pendekatan pada teknologi penampilan, dimana dalam tujuan pembelajaran disusun dalam menanggapi masalah atau kesempatan dalam sebuah struktur. Tidak ada pertimbangan atas gagasan sebelumnya dari apa yang harus dipelajari dari apa yang akan termasuk dalam tujuan pembelajaran atau dalam kenyataan adanya kebutuhan untuk semua pembelajaran. Pendesain terlibat dalam analisis pelaksanaan dan proses asesmen kebutuhan untuk mengidentifikasi masalah dengan tepat, dimana hal tersebut bukanlah tugas yang mudah.

Kegiatan menyusun rencana pembelajaran merupakan salah satu tugas penting guru dalam memproses pembelajaran siswa. Dalam perspektif kebijakan pendidikan nasional yang dituangkan dalam Permendiknas RI No. 52 Tahun 2008 tentang Standar Proses disebutkan bahwa salah satu komponen dalam penyusunan Rencana Pelaksanaan Pembelajaran (RPP) yaitu adanya tujuan pembelajaran yang di dalamnya menggambarkan proses dan hasil belajar yang diharapkan dapat dicapai oleh peserta didik sesuai dengan kompetensi dasar.

Agar proses pembelajaran dapat terkonsepsikan dengan baik, maka seorang guru dituntut untuk mampu menyusun dan merumuskan tujuan pembelajaran secara jelas dan tegas. Dengan harapan dapat memberikan pemahaman kepada para guru agar dapat merumuskan tujuan pembelajaran secara tegas dan jelas dari mata pelajaran yang menjadi tanggung jawabnya.

Salah satu sumbangan terbesar dari aliran psikologi behaviorisme terhadap pembelajaran bahwa pembelajaran seyogyanya memiliki tujuan. Gagasan perlunya tujuan dalam pembelajaran pertama kali dikemukakan oleh B.F. Skinner pada tahun 1950. 
Kemudian diikuti oleh Robert Mager pada tahun 1962 kemudian sejak pada tahun 1970 hingga sekarang penerapannya semakin meluas hampir di seluruh lembaga pendidikan di dunia, termasuk di Indonesia.

Merujuk pada tulisan Hamzah B. Uno (2008) berikut ini dikemukakan beberapa pengertian yang dikemukakan oleh para ahli. Robert F. Mager (1962) mengemukakan bahwa tujuan pembelajaran adalah perilaku yang hendak dicapai atau yang dapat dikerjakan oleh siswa pada kondisi dan tingkat kompetensi tertentu. Sementara itu, Oemar Hamalik (2005) menyebutkan bahwa tujuan pembelajaran adalah suatu deskripsi mengenai tingkah laku yang diharapkan tercapai oleh siswa setelah berlangsung pembelajaran .

\section{B. MATERI PEMBELAJARAN}

\section{Pengertian Materi Pembelajaran}

Secara garis besar dapat dikemukakan bahwa materi pembelajaran (instructional material) adalah pengetahuan, keterampilan, dan sikap yang harus dikuasai oleh peserta didik dalam rangka memenuhi standar kompetensi yang ditetapkan. Menurut National Center for Vocational Education Research Ltd ada tiga pengertian materi pembelajaran yaitu: a) merupakan informasi, alat dan teks yang diperlukan guru/ instruktur untuk perencanaan dan penelaah inplementasi pembelajaran; b) segala bentuk bahan yang digunakan untuk membantu guru/ instruktur dalam kegiatan belajar mengajar di kelas; c) seperangkat substansi pembelajaran yang disusun secara sistematis, menampilkan sosok yang utuh dari kompetensi yang akan dikuasai siswa dalam proses pembelajaran.

Materi pembelajaran menempati posisi yang sangat penting dari keseluruhan kurikulum, yang harus dipersiapkan agar pelaksanaan pembelajaran dapat mencapai sasaran yang sesuai dengan Standar Kompetensi dan Kompetensi Dasar. Artinya materi yang ditentukan untuk kegiatan pembelajaran hendaknya materi yang benar-benar menunjang tercapainya standar kompetensi dan kompetensi dasar serta indicator. 


\section{Jenis-Jenis Materi Pembelajaran}

Jenis-jenis materi pembelajaran dapat diklasifikasikan sebagai berikut:

a) Fakta adalah segala hal yang berwujud kenyataan dan kebenaran, meliputi nama-nama objek, peristiwa, lambang, nama tempat, nama orang dan lain sebagainya. Contoh: mulut, paru-paru

b) Konsep adalah segala yang berwujud pengertian-pengertian baru yang bisa timbul sebagai hasil pemikiran, meliputi definisi, pengertian, cirri khusus, hakikat, inti/isi dan sebagainya. Contoh: Hutan hujan tropis di Indonesia sebagai sumber plasma nutfah, Usaha-usaha pelestarian keanekargaman hayati Indonesia secara in-situ dan ex-situ, dsb.

c) Prinsip adalah berupa hal-hal pokok dan memiliki posisi terpenting meliputi dalil, rumus, paradigm, teori serta hubungan antar konsep yang menggambarkan implikasi sebab akibat.

Contoh: hukum Handy-Weinberg

d) Prosedur merupakan langkah-langkah sistematis atau berurutan dalam melakukan suatu aktivitas dan kronologi suatu sistem. Contoh: langkah-langkah dalam menggunakan metode ilmiah yaitu merumuskan masalah, observasi, hipotesis, melakukan eksperimen dan menarik kesimpulan.

e) Sikap atau nilai merupakan hasil belajar aspek sikap. Contoh: Pemanfaatan lingkungan hidup dan pembangunan berkelanjutan, yaitu pengertian lingkungan, komponen ekosistem, lingkungan hidup sebagai sumberdaya, pembangunan berkelanjutan

\section{Prinsip-Prinsip Penentuan Materi Pembelajaran}

Prinsip-prinsip yang dijadikan dasar dalam menentukan materi pembelajaran adalah:

a) Relevansi (kesesuaian)

Materi pembelajaran hendaknya relevan dengan pencapaian standar kompetensi dan kompetensi dasar. Jika kemampuan yang 
diharapkan dikuasai peserta didik berupa menghafal fakta, maka materi pembelajaran yang diajarkan harus berupa fakta, bukan konsep atau prinsip ataupun jenis materi lain. Contoh: kompetensi dasar yang harus dikuasai peserta didik adalah "mendeskripsikan sistim gerak pada manusia dan hubungannya dengan manusia" maka pemilihan materi pembelajaran yang disampaikan seharusnya"

b) Konsistensi (keajegan)

Jika kompetensi dasar yang harus dikuasai peserta didik ada dua macam maka materi yang diajarkan juga harus meliputi dua macam. Contoh: kompetensi dasar yang harus dikuasai peserta didik adalah "pengajaran mengenai sistem panca indera"

c) Adquency (kecukupan)

Materi yang diajarkan hendaknya cukup memadai dalam membantu peserta didik menguasai konpetensi dasar yang diajarkan. Materi tidak boleh terlalu sedikit dan tidak boleh terlalu banyak. Jika terlalu sedikit maka kurang membantu tercapainya standar kompetensi dan kompetensi dasar. Sebaliknya jika terlalu banyak maka akan mengakibatkan keterlambatan dalam pencapaian target kurikulum.

Dalam pengembangan materi belajar guru harus mampu mengidentifikasikan dan mempertimbangkan hal-hal berikut:

a) Potensi peserta didik meliputi potensi intelektual, emosional, spiritual, sosial dan potensi vokasional

b) Relevansi dan karakteristik daerah. Jika peserta didik bersekolah dan berlokasi di daerah pantai, maka pengembangan materi pembelajaran diupayakan agar selaras dengan kondisi masyarakat pantai.

c) Tingkat perkembangan fisik, intelektual, emosional, sosial dan spiritual peserta didik

d) Kebermanfaatan bagi peserta didik. Pengembangan materi pembelajaran diupayakan agar manfaatnya dapat dirasakan 
peserta didik dalam waktu yang relative singkat setelah suatu materi pembelajaran tuntas dilaksanakan.

e) Struktur keilmuan yang sesuai dengan materi pembelajaran suatu ilmu.

f) Aktulaitas, kedalaman dan keluasan materi pembelajaran. Mengembangkan materi pembelajaran hendaknya mempertimbangkan potensi peserta didik, tingkat perkembangan peserta didik, kebermanfaatan bagi peserta didik, alokasi waktu dan perkembangan peradaban dunia

g) Relevansi kebutuhan peserta didik dan tuntunan lingkungan

h) Alokasi waktu

\section{Cakupan Materi Pembelajaran}

Dalam cakupan atau ruang lingkup materi pembelajaran harus memperhatikan beberapa aspek berikut:

a) Aspek kognitif, aspek afektif atau aspek psikomotor, karena ketika sudah diimplementasikan dalam proses pembelajaran maka tiap-tiap jenis uraian materi tersebut memerlukan strategi dan media pembelajaran yang berbeda-beda. Selain memperhatikan jenis materi juga harus memperhatikan prinsipprinsip yang perlu digunakan dalam menentukan cakupan pembelajaran yang menyangkut keluasan dan kedalaman materi

b) Keluasan materi berarti menggambarkan seberapa banyak materi-materi yang dimasukkan ke dalam suatu materi pembelajaran. Kedalaman materi yang menyangkut rincian konsep-konsep yang terkandung di dalamnya yang harus dipelajari oleh peserta didik.

c) Kecakupan atau memadainya cakupan materi juga perlu diperhatikan. Memadainya cakupan aspek materi pembelajaran akan sangat membantu tercapainya penguasaan kompetensi dasar yang telah ditentukan. Cakupan atau ruang lingkup materi perlu ditentukan untuk mengetahui apakah materi yang akan diajarkan terlalu banyak, terlalu sedikit atau telah 
memadai sehingga terjadi kesesuaian dengan kompetensi dasar yang ingin dicapai.

\section{Kegiatan Pembelajaran}

Kegiatan Pembelajaran adalah suatu proses yang mengandung serangkaian kegiatan guru dan siswa atas dasar hubungan timbal balik yang berlangsung dalam situasi edukatif untuk mencapai tujuan tertentu. Menurut Winarno (1983) bahwa: pembelajaran adalah proses berlangsungnya kegiatan belajar dan membelajarkan siswa dikelas. Pelaksanaan pembelajaran adalah interaksi guru dan siswa dalam rangka menyampaikan bahan pelajaran kepada siswa dan untuk mencapai tujuan pembelajaran. Dari definisi tersebut diketahui bahwa dalam proses pembelajaran terdapat beberapa unsur diantaranya adalah pembelajaran sebagai sebuah proses yang bertujuan untuk membelajarkan siswa di dalam kelas. Dalam kegiatan pembelajaran terjadi proses interaksi yang bersifat edukatif antara guru dengan siswa. Kegiatan yang dilaksanakan tersebut bermuara pada satu tujuan yaitu untuk mencapai tujuan pembelajaran yang telah ditetapkan sebelumnya.

Pandangan lain yang sejalan dengan hal tersebut adalah yang dikemukakan oleh Ali (1992) bahwa pelaksanaan pembelajaran adalah pelaksanaan strategi-strategi yang telah dirancang untuk mencapai tujuan pembelajaran. Strategi, pendekatan, prinsip-prinsip dari metode pembelajaran diarahkan guna mencapai tujuan pembelajaran yang efisien dan efektif.

Berdasarkan kedua batasan tersebut diatas, dapat dipahami bahwa proses pembelajaran adalah merupakan suatu bentuk kegiatan yang dilaksanakan oleh guru dengan siswa dengan menjalin komunikasi edukatif dengan menggunakan strategi-strategi, pendekatan, prinsip dan metode tertentu dalam rangka mencapai tujuan pembeljaaran yang efektif dan efisien berdasarkan perencanaan yang telah dibuat sebelumnya. Oleh karena itu, kegiatan pembelajaran harus dilaksanakan dengan baik dan optimal sehingga tujuan-tujuan pembelajaran dapat dicapai dengan baik dan optimal pula. 
Efektivitas pembelajaran dapat tercapai sangat tergantung dari kemampuan guru untuk mencapai keberhasilan proses pembelajaran tersebut. Dalam pembelajaran di sekolah, terdapat proses belajar, yaitu proses terjadinya perubahan pengetahuan, sikap, informasi, kemampuan dan keterampilan yang sifatnya permanent melalui pengalaman.

Jadi, proses pembelajaran adalah merupakan suatu proses yang menjadi inti dari kegiatan transfer of knowledge dan transfer of action dari guru kepada siswa di sekolah. Secara sederhana proses pembelajaran adalah merupakan interaksi antara guru dengan siswa secara langsung dalam kelas, dalam rangka mentransfer ilmu pengetahuan dan tekhnologi dari guru kepada siswa.

Berdasarkan definisi tersebut di atas, maka belajar dapat diartikan sebagai suatu aktivitas individu yang berkelanjutan melalui kegiatan dan pengalaman sebagai hasil interaksi dengan lingkungan yang menyebabkan terjadinya perubahan pada individu, baik sikap maupun prilakunya. Perubahan tersebut dapat berupa perubahan pengetahuan, kemahiran, keterampilan, kepribadian, sikap, kebiasaan yang akhirnya mampu untuk melaksanakan tugas atau kerja tertentu dengan baik.

Menurut Suryosubroto (1988) belajar jika ditinjau dari spek hukum pertautan adalah "hubungan antara perangsang dan reaksi tingkah laku. Dengan demikian maka proses belajar adalah merupakan suatu proses dimana terjadi suatu ransangan dari seseorang yang akan ditanggapi berupa reaksi terhadap ransangan tersebut berupa tingkah laku yang akan berubah sedemikian rupa sesuai dengan perubahan ransangan yang diperolehnya. Jadi, proses belajar adalah merupakan proses asosiasi atau hubungan dan pertautan antara ransangan dan respon dari seseorang kepada orang lain yang menyebabkan terjadinya suatu perubahan. Dengan demikian, maka hasil dari belajar itu adalah perubahan yang terjadi dari seseorang yang tleah mengikuti proses belajar.

\section{METODE}




\section{Pengertian Metode Pembelajaran}

Metode menurut Djamaluddin dan Abdullah Aly dalam Kapita Selekta Pendidikan Islam, (1999:114) berasal dari kata meta berarti melalui, dan hodos jalan. Jadi metode adalah jalan yang harus dilalui untuk mencapai suatu tujuan. Sedangkan menurut Depag RI dalam buku Metodologi Pendidikan Agama Islam (2001:19) Metode berarti cara kerja yang bersistem untuk memudahkan pelaksanaan suatu kegiatan guna mencapai tujuan yang ditentukan. Menurut WJS. Poerwadarminta dalam Kamus Besar Bahasa Indonesia, (1999:767) Metode adalah cara yang telah teratur dan terpikir baikbaik untuk mencapai suatu maksud. Berdasarkan definisi di atas, penulis dapat mengambil kesimpulan bahwa metode merupakan jalan atau cara yang ditempuh seseorang untuk mencapai tujuan yang diharapkan.

Jadi pembelajaran merupakan proses interaksi peserta didik dengan pendidik dan sumber belajar pada suatu lingkungan belajar. Pembelajaran merupakan bantuan yang diberikan pendidik agar dapat terjadi proses pemerolehan ilmu dan pengetahuan. Jadi dapat dikatakan Teori belajar merupakan upaya untuk mendeskripsikan bagaimana manusia belajar, sehingga membantu kita semua memahami proses inhern yang kompleks dari belajar.

Berdasarkan uraian di atas dapat disimpulkan bahwa yang dimaksud metode pembelajaran adalah cara atau jalan yang ditempuh oleh guru untuk menyampaikan materi pembelajaran sehingga tujuan pembelajaran dapat dicapai. Dapat juga disimpulkan bahwa metode pembelajaran adalah strategi pembelajaran yang digunakan oleh guru sebagai media untuk mencapai tujuan pembelajaran yang telah ditetapkan. Hal ini mendorong seorang guru untuk mencari metode yang tepat dalam menyampaian materinya agar dapat diserap dengan baik oleh siswa. Mengajar secara efektif sangat bergantung pada pemilihan dan penggunaan metode mengajar.

\section{Macam-macam Metode Pembelajaran}


Metode pembelajaran banyak macam-macam dan jenisnya, setiap jenis metode pembelajaran mempunyai kelemahan dan kelebihan masing-masing, tidak menggunakan satu macam metode saja, mengkombinasikan penggunaan beberapa metode yang sampai saat ini masih banyak digunakan dalam proses belajar mengajar. Menurut Nana Sudjana(dalam buku Dasar-dasar Proses Belajar Mengajar, 1989:78-86), terdapat bermacam macam metode dalam pembelajaran, yaitu Metode ceramah, Metode Tanya Jawab, Metode Diskusi, Metode Resitasi, Metode Kerja Kelompok, Metode Demonstrasi dan Eksperimen, Metode sosiodrama (role-playing), Metode problem solving, Metode sistem regu (team teaching), Metode latihan (drill), Metode karyawisata (Field-trip), Metode survai masyarakat, dan Metode simulasi.

\section{Faktor-faktor yang Mempengaruhi Metode Pembelajaran}

Dalam melaksanakan suatu pembelajaran harus diawali dengan kegiatan perencanaan pembelajaran. Perencanaan memiliki fungsi penting agar pembelajaran menjadi lebih terarah. Dalam membuat perencanaan pembelajaran, banyak aspek yang harus dipertimbangkan oleh guru. Oleh karenanya agar pelaksanaan pembelajaran dapat berjalan dengan baik dan dapat meraih tujuan yang diharapkan, maka dalam menyusun learning design perlu memperhatikan faktor-faktor yang mempengaruhi pemilihan metode pembelajaran. Berikut ini merupakan faktor-faktor yang mempengaruhi pemilihan metode pembelajaran, antara lain:

\section{a) Siswa Atau Peserta Didik}

Pemilihan suatu metode pembelajaran, harus menyesuaikan tingkatan jenjang pendidikan siswa. Pertimbangan yang menekankan pada perbedaan jenjang pendidikan ini adalah pada kemampuan peserta didik, apakah sudah mampu untuk berpikir abstrak atau belum. Penerapan suatu metode yang sederhana dan yang kompleks tentu sangat berbeda, dan keduanya berkaitan dengan tingkatan kemampuan berpikir dan berperilaku peserta didik pada setiap jenjangnya 
b) Tujuan Pembelajaran Yang Akan Dicapai

Setiap pelaksanaan pembelajaran tentu memiliki tujuan pembelajaran yang hendak dicapai. Penyelenggaraan pembelajaran bertujuan agar pesera didik sebagai warga belajar akan memperoleh pengalaman belajar dan menunjukkan perubahan perilaku, dimana perubahan tersebut bersifat positif dan bertahan lama. Kalimat tersebut dapat dimaknai bahwa pembelajaran yang berhasil adalah pembelajaran yang tidak hanya akan menambah pengetahuan peserta didik tetapi juga berpengaruh terhadap sikap dan cara pandang peserta didik terhadap realitas kehidupan.

c) Faktor Materi Pembelajaran

Materi pelajaran memiliki tingkat kedalaman, keluasan, kerumitan yang berbeda-beda. Materi pembelajaran dengan tingkat kesulitan yang tinggi biasanya menuntut langkahlangkah analisis dalam tataran yang beragam. Analisis bisa hanya pada tataran dangkal, sedang, maupun analisis secara mendalam. Pemilihan metode pembelajaran yang tepat mampu memberikan arahan praktis untuk mengatasi tingkat kesulitan suatu materi pembelajaran.

d) Situasi Pembelajaran

Situasi pembelajaran yang diciptakan guru tidak

selamanya sama.Maka guru harus memilih metode mengajar yang sesuai dengan situasi yang diciptakan. Di waktu lain, sesuai dengan sifat bahan dan kemampuan yang ingin dicapai oleh tujuan maka guru menciptakan lingkungan belajar secara berkelompok. Jadi situasi yang diciptakan mempengaruhi pemilihan dan penentuan metode mengajar.

e) Fasilitas Pembelajaran

Fasilitas pembelajaran berfungsi untuk memudahkan proses pembelajaran dan pemenuhan kebutuhan proses pembelajaran. Bagi sekolah yang telah memiliki fasilitas pembelajaran yang lengkap, ketersediaan fasilitas belajar bukan lagi suatu kendala. 
Namun demikian tidak semua sekolah memiliki fasilitas pembelajaran dengan standar yang diharapkan. Keadaan tersebut hendaknya tidak menjadi suatu hambatan bagi guru dalam merancang pembelajaran yang tetap mampu menjangkau tujuan pembelajaran. Dalam kondisi tertentu, guru-guru yang memiliki semangat dan komitmen yang kuat tetap mampu menyelenggarakan pembelajaran yang menarik, menyenangkan, dan mampu mencapai tujuan pembelajaran yang diharapkan.

\section{f) Faktor alokasi waktu pembelajaran.}

Pemilihan metode pembelajaran yang tepat juga harus memperhitungkan ketersediaan waktu. Rancangan belajar yang baik adalah penggunaan alokasi waktu yang dihitung secara terperinci, agar pembelajaran berjalan dengan dinamis, tidak ada waktu terbuang tanpa arti. Kegiatan pembukaan, inti, dan penutup disusun secara sistematis. Dalam kegiatan inti yang meliputi tahap eksplorasi-elaborasi-konfirmasi, mengambil bagian waktu dengan porsi terbesar dibandingkan dengan kegiatan pembuka dan penutup.

g) Guru.

Latar belakang pendidikan guru diakui mempengaruhi kompotensi. Kurangnya penguasaan terhadap berbagai jenis metode menjadi kendala dalam memilih dan menentukan metode. Apalagi belum memiliki pengalaman mengajar yang memadai. Tetapi ada juga yang tepat memilih namun dalam dalam pelaksanaannya menemui kendala disebabkan labilnya kepribadian dan dangkalnya penguasaan atas metode yang digunakan

\section{Kriteria Pemilihan Metode Pembelajaran}

Kriteria pemilihan metode pembelajaran yaitu :
a) Sifat (karakter) guru.
b) Tingkat perkembangan intelektual dan sosial anak.
c) Fasilitas sekolah yang tersedia.
d) Tingkat Kemampuan Guru. 
e) Sifat dan tujuan materi pelajaran.

f) Waktu pembelajaran.

g) Suasana kelas.

h) Konteks domain tujuan pembelajaran.

Metode pembelajaran yang diterapkan guru hendaknya dapat mewujudkan hasil karya siswa. Siswa dituntun untuk dapat berfikir kritis dan kreatif dengan memberikan kesempatan kepada siswa untuk menyampaikan ide-idenya. Pemilihan metode yang kurang tepat dengan sifat bahan dan tujuan pembelajaran menyebabkan kelas kurang bergairah dan kondisi siswa kurang kreatif. Sehingga dengan penerapan metode yang tepat dengan berbagai macam indikator tersebut dapat meningkatkan minat siswa pada bahan pelajaran yang disampaikan danminat yang besar pada akhirnya akan berpengaruh terhadap prestasi yang akan diraihnya.

\section{ALAT}

\section{Pengertian Alat Pembelajaran}

a) Menurut Wijaya \& Rusyan (1994)yang dimaksud Alat Peraga Pendidikan adalah media pendidikan berperan sebagai perangsang belajar \& dapat menumbuhkan motivasi belajar sehingga siswa tidak menjadi bosan dalam meraih tujuan-tujuan belajar.

b) Menurut Nasution (1985) alat peraga pendidikan adalah alat pembantu dalam mengajar agar efektif.

c) Menurut Sudjana (2009)Pengertian Alat Peraga Pendidikan adalah suatu alat yang dapat diserap oleh mata \& telinga dengan tujuan membantu guru agar proses belajar mengajar siswa lebih efektif \& efisien.

d) Menurut Faizal (2010)Alat Peraga Pendidikan sebagai instrument audio maupun visual yang digunakan untuk membantu proses pembelajaran menjadi lebih menarik \& membangkitkan minat siswa dalam mendalami suatu materi.

\section{Tujuan dari alat peraga}


Berikut ini beberapa tujuan alat peraga disebutkan selain di atas tadi, ialah sebagai berikut:

a) Alat peraga dalam pendidikan memiliki tujuan supaya proses pendidikan lebih efektif dengan jalan meningkatkan semangat belajar para siswa.

b) Alat peraga pendidikan dapat memungkinkan lebih sesuai dengan perorangan, dimana siswa belajar dengan banyak sekali kemungkinan, sehingga belajar dapat berlangsung sangat menyenangkan bagi masing-masing individu.

c) Alat peraga pendidikan mempunyai manfaat supaya belajar lebih cepat segera bersesuaian antara kelas dan diluar kelas, alat peraga dapat memungkinkan mengajar lebih sistematis dan juga teratur.

\section{Manfaat dari alat peraga}

Untuk lebih jelas dan terperinci, berikut ini manfaat dari penggunaan alat peraga pendidikan yaitu antara lain sebagai berikut ini:

a) Menimbulkan minat sasaran pendidikan.

b) Mencapai sasaran yang lebih banyak.

c) Dapat membantu dalam mengatasi berbagai macam hambatan dalam proses pendidikan.

d) Dapat merangsang sasaran dari pendidikan untuk mengimplementasikan ataupun melaksanakan pesan-pesan kesehatan atau pesan pendidikan yang akan disampaikan.

e) Dapat membantu sasaran pendidikan untuk belajar dengan cepat serta belajar lebih banyak materi atau bahan yang disampaikan .

f) Merangsang sasaran pendidikan untuk bisa meneruskan berbagai pesan yang disampaikan yang member materi kepada orang lain.

g) Dapat mempermudah saat penyampaian materi pendidikan atau informasi oleh para pendidik.

h) Dapat Mendorong keinginan orang-orang maupun individu untuk mengetahui, lalu kemudian lebih mendalami, lalu pada 
akhirnya mendapatkan pengertian yang lebih baik. Individu yang melihat sesuatu yang memang ia diperlukan tentu akan menarik perhatiannya. Dan juga apa yang dilihat dengan penuh perhatian akan dapat memberikan pengertian baru untuknya, yang merupakan pendorong untuk melakukan ataupun memakai sesuatu yang baru tersebut.

i) Membantu menegakkan pengertian atau informasi yang diperoleh. Sasaran pendidikan di dalam menerima sesuatu yang baru, manusia memiliki kecenderungan untuk melupakan/lupa. Oleh karena itu, untuk mengatasi hal tersebut, AVA (Audio Visual Aid alat bantu atau peraga audio visual) dapat membantu menegakkan pengetahuan-pengetahuan yang sudah diterima oleh sasaran pendidikan sehingga apa yang diterima akan lebih lama tersimpan di dalam ingatan si penerima.

\section{E. SUMBER BELAJAR}

Sumber belajar (learning resources) adalah semua sumber baik berupa data, orang dan wujud tertentu yang dapat digunakan oleh peserta didik dalam belajar, baik secara terpisah maupun secara terkombinasi sehingga mempermudah peserta didik dalam mencapai tujuan belajar atau mencapai kompetensi tertentu. Adapun para ahli telah mengemukakan pendapat tentang pengertian sumber belajar sebagai berikut:

1) Menurut Yusufhadi Miarso adalah segala sesuatu yang meliputi pesan, orang, bahan, alat, teknik, dan lingkungan, baik secara tersendiri maupun terkombinasikan dapat memungkinkan terjadinya belajar.

2) Edgar Dale mengemukakan sumber belajar adalah segala sesuatu yang dapat dimanfaatkan untuk memfasilitasi belajar seseorang.

3) Menurut Rohani sumber belajar (learning resources) adalah segala macam sumber yang ada di luar diri seseorang (peserta didik) dan yang memungkinkan (memudahkan) terjadinya proses belajar. 
4) Association Educational Communication and Technology (AECT), yang menyatakan bahwa sumber belajar adalah semua sumber baik berupa data, orang dan wujud tertentu yang dapat digunkan siswa dalam belajar, baik secara terpisah maupun terkombinasi sehingga mempermudah siswa dalam mecapai tujuan belajar.

Sumber-sumber belajar dapat berbentuk:

1) Pesan: informasi, bahan ajar; cerita rakyat, dongeng, hikayat, dan sebagainya;

2) Orang: guru, instruktur, siswa, ahli, nara sumber, tokoh masyarakat, pimpinan lembaga, tokoh karier dan sebagainya;

3) Bahan: buku, transparansi, film, slides, gambar, grafik yang dirancang untuk pembelajaran, relief, candi, arca, komik, dan sebagainya;

4) Alat/ perlengkapan: perangkat keras, komputer, radio, televisi, VCD/DVD, kamera, papan tulis, generator, mesin, mobil, motor, alat listrik, obeng dan sebagainya;

5) Pendekatan/ metode/ teknik: disikusi, seminar, pemecahan masalah, simulasi, permainan, sarasehan, percakapan biasa, diskusi, debat, talk shaw dan sejenisnya;

6) Lingkungan: ruang kelas, studio, perpustakaan, aula, teman, kebun, pasar, toko, museum, kantor dan sebagainya.

\section{F. EVALUASI}

Evaluasi adalah kegiatan untuk mengumpulkan informasi tentang bekerjanya sesuatu, yang selanjutnya informasi tersebut digunakan untuk menentukan alternatif yang tepat dalam mengambil keputusan. dan evaluasi juga kegiatan untuk mengetes tingkat kecakapan seseorang satau kelompok orang

Semua kegiatan mengajar belajar perlu dievaluasi. Evaluasi dapat memberi motivasi bagi guru maupun siswa, mereka akan lebih giat belajar, meningkatkan proses berpikirnya. Dengan evaluasi guru dapat mengetahui prestasi dan kemajuan siswa, sehingga dapat bertindak yang tepat bila siswa mengalami kesulitan belajar 
Bagi siswa, evaluasi merupakan umpan balik tentang kelebihan dan kelemahan yang dimiliki, dapat mendorong belajar lebih baik dan meningkatkan motivasi berprestasi. Evaluasi terhadap siswa dilakukan untuk mengetahui sampai sejauh mana kemajuan yang telah mereka capai. Evaluasi tidak hanya dilakukan oleh guru tetapi juga oleh siswa untuk mengevaluasi diri mereka sendiri (self assessment) atau evaluasi diri. Evaluasi diri dilakukan oleh siswa terhadap diri mereka sendiri, maupun terhadap teman mereka. Hal ini akan mendorong siswa untuk berusaha lebih baik lagi dari sebelumnya agar mencapai hasil yang maksimal. Mereka akan merasa malu kalau kelemahan dan kekurangan yang dimiliki diketahui oleh teman mereka sendiri. Evaluasi terhadap diri sendiri merupakan evaluasi yang mendukung proses belajar mengajar serta membantu siswa meningkatkan keberhasilannya. Oleh karena itu, untuk mempengaruhi hasil belajar siswa evaluasi perlu dilaksanakan dalam kegiatan pembelajaran. 


\section{BAB V \\ TEORI-TEORI BELAJAR DAN PEMBELAJARAN}

\section{A. TEORI DESKRIPTIF DAN PRESPEKTIF}

Teori belajar adalah deskriptif karena tujuan utamanya menjelaskan proses belajar, sedangkan teori pembelajaran adalah preskriptif karena tujuan utamanya menetapkan metode pembelajaran yang optimal.

Adapun Teori pembelajaran preskriptif dimaksudkan untuk mencapai tujuan, sedangkan teori pembelajaran deskriptif dimaksudkan untuk memberikan hasil. Itulah sebabnya, variabel yang diamati dalam teori-teori pembelajaran yang preskriptif adalah metode yang optimal untuk mencapai tujuan. Adapun contohnya yaitu agar dapat mengingat isi bahan ajar yang dibaca secara lebih baik, maka bacalah isi bahan ajar ini tersebut berulang-ulang dan buatlah rangkumannya. Ada beberapa pendapat teori belajar deskriptif dan preskriptif menurut :

\section{Menurut Bruner}

Teori pembelajaran adalah preskriptif dan teori belajar adalah deskriptif. Preskriptif karena tujuan utama teori pembelajaran adalah menetapkan metode pembelajaran yang optimal, sedangkan deskriptif karena tujuan utama teori belajar adalah menjelaskan proses belajar.

\section{Menurut Reigeluth}

Teori preskriptif adalah goal oriented, sedangkan teori deskriptif adalah goal free. Maksudnya adalah bahwa teori pembelajaran preskriptif dimaksudkan untuk mencapai tujuan, sedangkan teori pembelajaran deskriptif dimaksudkan untk memberikan hasil.

\section{Bruner (1964)}

diakui oleh kalangan instructional theorist sebagai peletak dasar pengembang teori-teori pembelajaran, di samping Skinner (1954) dan Ausubel (1968). Bruner (1964) membuat pembedaan antara 
teori belajar dan teori pembelajaran. Teori belajar adalah deskriptif, sedangkan teori pembelajaran adalah preskriptif. Teori belajar mendeskripsikan adanya proses belajar, teori pembelajaran mempreskripsikan strategi atau metode pembelajaran yang optimal yang dapat mempermudah proses belajar.

\section{Simon (Degeng, 1989)}

mengemukakan perbedaan serupa dengan memaparkan persamaan karakteristik dari "a prescriptive science" dan membandingkan dengan karakteristik dari "a descriptive science". Dalam kerangka ini nyata sekali bahwa teori pembelajaran termasuk teori preskriptif yang berpasangan dengan teori belajar yang termasuk teori deskriptif.

Dalam ilmu preskriptif terlibat tiga jenis profesi, yaitu: Ilmuwan, Teknolog dan Teknisi. Teori belajar menaruh perhatian pada hubungan diantara variabel-variabel yang menentukan hasil belajar. Teori belajar menaruh perhatian pada "bagaimana seseorang belajar". Sebaliknya teori pembelajaran menaruh pehatian pada bagaimana seseorang mempengaruhi orang lain untuk belajar. Teori pembelajaran berurusan dengan upaya mengontrol variabel-variabel.

Pembedaan teori belajar (deskriptif) dan pembelajaran (preskriptif) dikembangkan oleh Bruner, lebih lanjut oleh Reigeluth (1983), Gropper (1983), dan Landa (1983). Menurut Reigeluth (dalam Degeng 1989) teori-teori dan prinsip pembelajaran yang deskriptif menempatkan variabel kondisi dan metode pembelajaran sebagai givens dan memerikan hasil pembelajaran sebagai variabel yang diamati. Dengan kata lain kondisi dan metode pembelajaran sebagai variabel bebas dan hasil pembelajaran sebagai variabel tergantung.

Sebaliknya dalam teori-teori dan prinsip-prinsip pembelajaran yang preskriptif menempatkan kondisi dan hasil sebagai givens sedangkan metode yang optimal ditetapkan sebagai variabel yang bisa diamati. Jadi metode pembelajaran sebagai variabel tergantung. Teori preskriptif adalah goal oriented, sedangkan teori deskriptif adalah 
goal free (Reigeluth, 1983). Artinya teori pembelajaran preskriptif adalah untuk mencapai tujuan, sedangkan teori pembelajaran deskriptif dimaksudkan untuk memerikan hasil.

Untuk membedakan antara teori belajar dan teori pembelajaran bisa diamati dari posisional teorinya, apakah berada pada tataran teori deskriptif atau perspektif. Bruner (dalam Dageng 1989) mengemukakan bahwa teori pembelajaran adalah perspektif dan teori belajar adalah deskriptif. Perspektif karena tujuan utama teori pembelajaran adalah menetapkan metode pembelajaran yang optimal, sedangkan teori belajar bersifat deskritif karena tujuan utama teori belajar adalah menjelaskan proses belajar.

Teori belajar menaruh perhatian pada hubungan aantara variable-variabel yang menentukan hasil belajar. Sedangkan teori pembelajaran sebaliknya teori ini menaruh perhatian pada bagaimana seseorang mempengaruhi orang lain agar terjadi proses belajar. Dengan kata lain teori pembelajaran berurusan dengan upaya mengontrol variable yang dispesifikasikan dalam teori belajar agar dapat memudahkan belajar. (C.Asri Budiningsih,2004).

Asri Budiningsih (2004) dalam buku Belajar dan Pembelajaran menjelaskan bahwa upaya dari Bruner untuk membedakan antara teori belajar yang deskriptif dan teori pembelajaran yang perspektif dikembangkan lebih lanjut oleh Reigeluth.teori dan prinsip-prinsip pembelajaran yang deskriptif menempatkan variable kondisi dan metode pembelajaran sebagai givens dan menempatkan hasil belajar sebagai varibael yang diamati. Dengan kata lain, kondisi dan metode pembelajaran sebagai variable bebas dan hasil pembelajaran sebagai variable tergantung. Reigeluth (1983 dalam degeng ,1990) mengemukakan bahwa teori perspektif adalah goal oriented sedangkan teori deskriptif adalah goal free.

Maksudnya adalah bahwa teori pembelajaran perspektif dimaksudkan untuk mencapai tujuan, sedangkan teori belajar deskriptif dimaksudkan untuk memberikan hasil. Itulah sebabnya variable yang diamati dalam mengembangkan teori belajar yang 
perspektif adalah metode yang optimal untuk mencapai tujuan, sedangkan dalam pengembangan teori pem,belajaran deskriptif, variable yang diamati adalah hasil belajar sebagai akibat dari interaksi antara metode dan kondisi. Dengan kata lain teori pembelajaran mengungkapkan hubungan antara kegiatan pembelajaran dengan proses psikologis dalam diri siswa, sedangkan teori belajar mengungkapkan hubungan antara kegiatan siswa dengan proses psikologi dalam diri siswa.

Teori pembelajaran harus memasukkan variable metode pembelajaran. Bila tidak, maka teori itu bukanlah teori pembelajaran. Hal ini penting sebab banyak yang terjadi apa yang dianggap sebagai teori pembelajaran yang sebenarnya adalah teori belajar. Teori pembelajaran selalu menyebutkan metode pembelajaran sedangkan teori belajar sama sekali tidak berurusan dengan metode pembelajaran.

\section{B. TEORI BELAJAR BEHAVIORISTIK}

Imron (1996:3-9) mengemukakan bahwa teori behavioristik belajar adalah suatu kontrol instrumental yang berasal dari lingkungan. Pendidik mengkondisikan sedemikian rupa sehingga pembelajar mau belajar. Mengajar dengan demikian dilaksanakan dengan kondisioning, pembiasaan, peniruan, hadiah dan hukuman sering ditawarkan dalam proses pembelajaran. Kedaulatan guru dalam belajar demikian relatif tinggi, sementara kedaulatan siswa sebaliknya relatif rendah. Teori ini juga disebut teori conditioning, karena belajar tidaknya seseorang bergantung kepada faktor-faktor kondisional yang diberikan oleh lingkungan. Selain itu, Behaviorisme, sebagai teori pembelajaran, dapat ditelusuri kembali oleh Aristoteles, yang esainya "Memori" yang berfokus pada asosiasi yang dibuat antara peristiwa seperti kilat dan guntur. Lain filsuf yang mengikuti pemikiran Aristoteles adalah Hobbes (1650), Hume (1740), Brown (1820), Bain (1855) dan Ebbinghause (1885) (Black, 1995). Ivan Pavlov, John B. Watson, Edward Thorndike dan B.F. Skinner kemudian 
mengembangkan teorinya lebih terinci. Watson adalah ahli teori yang dipercayai menciptakan istilah "behaviourisme" (Watson,John Broadus, 1913).

Menurut teori behavioristik, belajar adalah perubahan tingkah laku sebagai akibat dari adanya interaksi antara stimulus dan respon. Seseorang dianggap telah belajar sesuatu jika ia dapat menunjukkan perubahan tingkah lakunya. Menurut teori ini yang terpenting adalah masukan atau input yang berupa stimulus dan keluaran atau output yang berupa respon. Stimulus adalah apa saja yang diberikan pendidik kepada pembelajar, sedangkan respon adalah reaksi atau tanggapan pembelajar terhadap stimulus yang diberikan oleh pendidik tersebut. Contoh: ketika pembelajar diberi tugas pendidik, ketika tugasnya ditambahkan maka ia akan semakin giat belajarnya. Maka penambahan tugas belajarnya tersebut merupakan penguatan positif dalam belajar. Bila tugas-tugas dikurangi dan pengurangan ini justru meningkatkan aktivitas belajarnya, maka pengurangan tugas merupakan suatu bentuk stimulus negatif dalam belajar. Jadi penguatan merupakan suatu bentuk stimulus yang penting diberikan (ditambahkan) atau dihilangkan (dikurangi) untuk memungkinkan terjadinya respon (Budiningsih: 2005:20-21).

Tokoh-tokoh teori belajar behavioristik antara lain adalah Pavlov, Gutrie, Watson, Skinner dan Thorndike.

\section{Teori belajar menurut Pavlov}

Bentuk paling sederhana dalam belajar adalah conditioning. Karena conditioning sangat sederhana bentuknya dan sangat luas sifatnya, para ahli sering mengambilnya sebagai contoh untuk menjelaskan dasar-dasar dari semua proses belajar. Peletak dasar teori conditioning adalah Ivan Petrovich Pavlov. Secara kebetulan conditioning refleks (psychic refleks) ditemukan oleh Pavlov pada waktu ia sedang mempelajari fungsi perut dan mengukur cairan yang dikeluarkan dari perut ketika anjing (sebagai binatang percobaannya) sedang makan. Ketika Pavlov mengukur sekresi perut saat anjing merespon bubuk makanan dia melihat bahwa 
hanya dengan melihat makanan telah menyebabkan anjing mengeluarkan air liur. Selain itu ketika anjing mendengar langkah kaki peneliti juga mengeluarkan air liur. Pada awalnya Pavlov menganggap respons tersebut sebagai reflek "psikis".

Menurut Pavlov (1927), ia melakukan percobaan terhadap anjing. Anjing tersebut diberi makanan dan diberi lampu/bel. Pada saat diberi makanan dan lampu keluarlah respon anjing tersebut berupa keluarnya air liur. Pada saat lampu dinyalakan mendahului makanan, anjing tersebut juga mengeluarkan air liur. Makanan yang diberikan tersebut oleh Pavlov disebut sebagai perangsang tak bersyarat (unconditioned stimulus/UCS), sementara lampu/bel yang menyertai disebut sebagai perangsang bersyarat (conditioned stimulus/CS). Terhadap perangsang tak bersyarat/UCR (makanan) yang disertai dengan perangsang bersyarat/CS (lampu/bel) tersebut, anjing memberikan respon (keluarnya air liur) (unconditioned renponse/UCR).

\section{Teori Belajar Menurut Edwin Guthrie}

Azas belajar Guthrie yang utama adalah hukum kontiguiti. yaitu gabungan stimulus-stimulus yang disertai suatu gerakan, pada waktu timbul kembali cenderung akan diikuti oleh gerakan yang sama (Gredler, 1991). Guthrie juga menggunakan variabel hubungan stimulus dan respon untuk menjelaskan terjadinya proses belajar. Belajar terjadi karena gerakan terakhir yang dilakukan mengubah situasi stimulus sedangkan tidak ada respon lain yang dapat terjadi. Penguatan sekedar hanya melindungi hasil belajar yang baru agar tidak hilang dengan jalan mencegah perolehan respon yang baru. Hubungan antara stimulus dan respon bersifat sementara, oleh karena dalam kegiatan belajar peserta didik perlu sesering mungkin diberi stimulus agar hubungan stimulus dan respon bersifat lebih kuat dan menetap. Guthrie juga percaya bahwa hukuman (punishment) memegang peranan penting dalam proses belajar. Hukuman yang diberikan pada saat yang tepat akan mampu mengubah tingkah laku seseorang. 
Menurut Gutrie (1935-1942), berpendapat bahwa tingkah laku manusia itu dapat diubah, tingkah laku baik dapat diubah menjadi jelek dan sebaliknya, tingkah laku jelek dapat diubah menjadi baik. Teori belajar Gutrie berdasarkan atas model penggantian stimulus satu ke stimulus yang lain. Respon atas suatu situasi cenderung diulang manakala individu menghadapi siatuasi yang sama. Teori Gutrie juga disebut teori asosiasi. Menurut Gutrie, setiap situasi belajar merupakan gabungan berbagai stimulus (dapat internal dan dapat eksternal) dan respons. Dalam situasi tertentu, banyak stimulus yang berasosiasi dengan banyak respons. Asosiasi tersebut, dapat benar dan dapat juga salah.

\section{Teori Belajar Menurut Watson}

Watson mendefinisikan belajar sebagai proses interaksi antara stimulus dan respon, namun stimulus dan respon yang dimaksud harus berbentuk tingkah laku yang dapat diamati (observable) dan dapat diukur. Dengan kata lain, meskipun ia mengakui adanya perubahan-perubahan mental dalam diri seseorang selama proses belajar, namun ia menganggap hal-hal tersebut sebagai faktor yang tak perlu diperhitungkan. Ia tetap mengakui bahwa perubahan-perubahan mental dalam bentuk benak siswa itu penting, namun semua itu tidak dapat menjelaskan apakah seseorang telah belajar atau belum karena tidak dapat diamati.

Teori behavioristik Watson disebut teori belajar S-R (stimulus-respon) yang disebut teori behaviorisme atau teori koneksionisme menurut Thorndike, namun dalam perkembangan besarnya koneksionisme juga dikenal dengan psikologi behavioristik. Stimulus dan respon (S-R) tersebut memang harus dapat diamati, meskipun perubahan yang tidak dapat diamati seperti perubahan mental itu penting, namun menurutnya tidak menjelaskan apakah proses belajar tersebut sudah terjadi apa belum. Dengan asumsi demikian, dapat diramalkan perubahan apa yang akan terjadi pada anak. Teori perubahan perilaku (belajar) 
dalam kelompok behaviorisme ini memandang manusia sebagai produk lingkungan. Segala perilaku manusia sebagian besar akibat pengaruh lingkungan sekitarnya. Lingkunganlah yang membentuk kepribadian manusia. Behaviorisme tidak bermaksud mempermasalahkan norma-norma pada manusia. Apakah seorang manusia tergolong baik, tidak baik, emosional, rasional, ataupun irasional. Di sini hanya dibicarakan bahwa perilaku manusia itu sebagai akibat berinteraksi dengan lingkungan, dan pola interaksi tersebut harus bisa diamati dari luar. Belajar dalam teori behaviorisme ini selanjutnya dikatakan sebagai hubungan langsung antara stimulus yang datang dari luar dengan respons yang ditampilkan oleh individu. Respons tertentu akan muncul dari individu, jika diberi stimulus dari luar. S singkatan dari Stimulus, dan R singkatan dari Respons.

Pada umumnya teori belajar yang termasuk ke dalam keluarga besar behaviorisme memandang manusia sebagai organisme yang netral-pasif-reaktif terhadap stimuli di sekitar lingkungannya. Orang akan bereaksi jika diberi rangsangan oleh lingkungan luarnya. Demikian juga jika stimulus dilakukan secara terus menerus dan dalam waktu yang cukup lama, akan berakibat berubahnya perilaku individu. Misalnya dalam hal kepercayaan sebagian masyarakat tentang obat-obatan yang diiklankan di televisi. Mereka sudah tahu dan terbiasa menggunakan obat-obat tertentu yang secara gencar ditayangkan media televisi. Jika orang sakit maag maka obatnya adalah promag, waisan, mylanta, ataupun obat-obat lain yang sering diiklankan televisi. Jenis obat lain tidak pernah digunakannya untuk penyakit maag tadi, padahal mungkin saja secara higienis obat yang tidak tertampilkan, lebih manjur, misalnya: Syarat terjadinya proses belajar dalam pola hubungan S$\mathrm{R}$ ini adalah adanya unsur: dorongan (drive), rangsangan (stimulus), respons, dan penguatan(reinforcement).

\section{Teori Belajar Menurut Skinner}


Skinner (1969), mengembangkan teori conditioning dengan menggunakan tikus sebagai kelinci percobaan. Dari hasil percobaannya, Skinner membedakan respons menjadi dua, yaitu respon yang timbul dari stimulus tertentu dan operant (instrumental) respon yang timbul dan berkembang karena diikuti oleh perangsang tertentu. Oleh karena itulah teori Skinner ini dikenal dengan teori operant conditioning. Ada 6 konsep teori operant conditioning yaitu :

a. Penguatan positif dan negatif. Penguatan adalah stimuli yang perlu diberikan atau dihilangkan untuk memungkinkan terjadinya respon. Penguatan positif adalah setiap stimulus yang keberadaannya dapat memantapkan respon yang diberikan. Penguatan negatif adalah semua stimulus yang perlu dihilangkan untuk memantapkan respon yang diberikan. Jadi penguatan adalah pemberian stimulus positif atau penghilangan stimulus negatif, sedang hukuman merupakan pemberian stimulus negatif atau penghilangan stimulus positif.

b. Shapping, ialah proses pembentukan tingkah laku yang makin mendekati tingkah laku yang diharapkan bisa juga disebut peniruan.

c. Pendekatan suksesif, ialah proses pembentukan tingkah laku yang menggunakan penguatan pada saat yang tepat sehingga responpun sesuai dengan yang diisyaratkan.

d. Extinction, ialah proses penghentian kegiatan sebagai akibat ditiadakannya penguatan.

e. Chaining of respons, yaitu repon dan stimulus yang berangkaian satu sama lain.

f. Jadwal penguatan, ialah variasi pemberian penguatan, rasio tetap (penguatan tergantung jumlah respon yang diberikan) dan bervariasi, interval tetap (penguatan tergantung waktu) dan bervariasi (Imron, 1996). Asas-asas operant kondisioning adalah kelanjutan dari tradisi yang didirikan oleh John Watson. Artinya, agar psikologi bisa menjadi suatu ilmu, maka studi tingkah laku 
harus dijadikan fokus penelitian psikologi. Tidak seperti halnya teoritikusteoritikus S-R lainnya, Skinner menghindari kontradiksi yang ditampilkan oleh model kondisioning klasik dari Pavlov dan kondisioning instrumental dari Thorndike.

\section{Teori Belajar Menurut Thorndike}

Menurut Thorndike (1949), belajar dapat dilakukan dengan mencoba-coba (trial and error). Mencoba-coba ini dilakukan, manakala seseorang tidak tahu bagaimana harus memberikan respon atas sesuatu. Dalam mencoba-coba ini seseorang mungkin akan menemukan respon yang tepat berkaitan dengan persoalan yang dihadapinya. Karakteristik belajar secara trial and error adalah sebagai berikut: a. Adanya motif pada diri seseorang yang mendorong untuk melakukan sesuatu. b. Seseorang berusaha melakukan berbagai macam respon dalang rangka memenuhi motif-motifnya. c. Respon-respon yang dirasakan tidak bersesuaian dengan motifnya dihilangkan. d. Akhirnya, seseorang mendapatkan jenis respon yang paling tepat.

Menurut Romiszowski (1981:4) dalam Winataputra (1996:2), Tim MKDK IKIP Semarang (1989:109) dan Irawan (2001:3) bahwa pendekatan behaviorist khususnya teori Thorndike disebut juga teori connectionist, karena pendekatan ini melihat proses belajar sebagai proses terjadinya hubungan antara stimulus atau rangsangan (pikiran, perasaan, gerakan) dengan respon atau jawaban (pikiran, perasaan, gerakan) atau antara respon dengan penguatan atau reinforcement.

Menurut Irawan (2001:2), teori belajar behavioristik disebut juga teori belajar tingkah laku. Teori tingkah laku menekankan pada "hasil" dari proses belajar. Menurut teori ini, (1) belajar adalah perubahan tingkah laku. Seseorang dianggap telah belajar sesuatu bila ia mampu menunjukkan perubahan tingkah laku (siswa belum bisa membaca menjadi bisa membaca); (2) yang terpenting adalah masukan/input yang berupa stimulus dan keluaran yang berupa respons. Sedangkan apa yang terjadi di antara stimulus dan 
respon itu dianggap tidak penting diperhatikan sebab tidak bisa diamati, yang bisa diamati, diukur hanyalah stimulus dan respon (tersurat tidak boleh tersirat); (3) faktor lain yang penting adalah penguatan, bila penguatan ditambah maka respon akan semakin kuat, tetapi bila penguatan dikurangi, responpun akan tetap dikuatkan.

\section{TEORI BELAJAR KOGNITIVISTIK}

Menurut penganut paham behaviorisme, belajar merupakan suatu perubahan perilaku yang dapat dilihat oleh mata dan dipengaruhi oleh adanya stimulus dan respons. Teori behavioristik sangat menekankan pada hasil belajar (outcome), yaitu perubahan tingkah laku yang dapat dilihat, dan tidak begitu memperhatikan apa yang terjadi di dalam otak manusia karena hal tersebut tidak dapat dilihat. Seorang dianggap telah belajar sesuatu apa ia mampu menunjukkan perubahan tingkah laku (Winataputra, 2008 hal.2.6). Di lain pihak, ahli teori belajar kognitif memandang bahwa belajar bukan semata-mata proses perubahan tingkah laku yang tampak, melainkan sesuatu yang kompleks yang sangat dipengaruhi oleh kondisi mental siswa yang tidak tampak. Udin S. Winataputra, dkk. (2008 : 3.0).

Sejalan dengan pendapat di atas, menurut Budiningsi (2012, hal. 34) bahwa teori belajar kognitif berbeda dengan teori belajar behavioristik. Teori belajar kognitif lebih mementingkan proses belajar dari pada hasil belajarnya. Para penganut aliran kognitif mengatakan bahwa belajar tidak sekedar melibatkan hubungan antara stimulus dan respon. Tidak seperti model belajar behavioristik yang mempelajari proses belajar hanya sebagai hubungan stimulus-respon, model belajar kognitif merupakan suatu bentuk teori belajar yang sering disebut sebagai model perseptual. Model belajar kognitif mengatakan bahwa tingkah laku seseorang ditentukan persepsi dan pemahamannya tentang situasi yang berhubungan dengan tujuan belajar. Belajar merupakan persepsi dan pemahaman yang tidak selalu dapat terlihat sebagai tingkah laku yang tampak.

\section{a. Prinsip Dasar dan tujuan Teori Belajar Kognitif.}


Teori kognitif ini dikembangkan terutama untuk membantu guru memahami muridnya dan juga dapat membantu guru memahami dirinya sendiri dengan baik. Menurut teori kognitif, belajar diartikan sebagai proses interaksional seseorang memperoleh pemahaman baru atau struktur kognitif dan mengubah hal-hal yang lama. Agar belajar menjadi efektif, guru harus memperhatikan dirinya sendiri dan orang lain. Jadi, psikologis kognitif dikembangkan dengan maksud membantu memahami muridnya dengan baik. Psikologi kognitif mengembangkan sistem psikologis yang bermanfaat untuk berhubungan dengan anak-anak dan pemuda pada saat belajar.

Teori belajar kognitif dibentuk dengan tujuan mengkonstruksi prinsip-prinsip belajar secara ilmiah. Hasilnya berupa prosedur-prosedur yang dapat diterapkan pada situasi kelas untuk mendapatkan hasil yang produktif. Teori belajar kognitif menjelaskan bagaimana seseorang mencapai pemahaman atas dirinya dan lingkungannya lalu menafsirkan bahwa diri dan lingkungan psikologisnya merupakan faktor-faktor yang kaitmengait. Teori ini dikembangkan berdasarkan tujuan yang melatarbelakangi perilaku, cita-cita, cara-cara dan bagaimana seseorang memahami diri dan lingkungannya dalam usaha untuk mencapai tujuan dirinya.

\section{b. Teori belajar kognitif menurut Pakar Kognitif}

1) Teori belajar kognitif menurut Jean Piaget

Teori perkembangan kognitif disebut pula teori perkembangan intelektual atau teori perkembangan mental. Teori berkenaan dengan kesiapan anak untuk belajar yang dikemas dalam tahaptahap perkembangan intelektual sejak lahir sampai dewasa. Menurut Piaget, perkembangan kognitif merupakan suatu proses yang didasarkan atas mekanisme biologis perkembangan sistem syaraf. Dengan makin bertambahnya usia seseorang, maka makin komplekslah susunan sel sarafnya dan makin meningkat pula kemampuannya. Atas dasar pemikiran ini maka Piaget disebut- 
sebut cenderung menganut teori psikogenesis, artinya pengetahuan sebagai hasil belajar berasal dari dalam individu. Menurut Piaget, proses belajar akan terjadi jika mengikuti tahaptahap asimilasi, akomodasi dan ekuilibrasi (penyeimbangan). Proses asimilasi merupakan proses pengintegrasian atau penyatuan informasi baru ke dalam struktur kognitif yang telah dimiliki oleh individu. Proses akomodasi merupakan proses penyesuaian struktur kognitif ke dalam situasi yang baru. Sedangkan proses ekuilibrasi adalah penyesuaian kesinambungan antara asimilasi dan akomodasi.

2) Teori belajar kognitif menurut Jerome S. Bruner

Jerome S. Bruner adalah imigrasi dari Polandia yang dibesarkan di New York. Bukunya tentang pendidikan yang terlihat mendukung prinsip kognitivisme antara lain adalah The Process of Education (1960), dan The Culture of Education (1996). Dasar dari teori Bruner adalah ungkapan Piaget yang menyatakan bahwa anak harus berperan secara aktif saat belajar di kelas. Konsepnya adalah belajar menemukan (discovery learnig), siswa mengorganisir bahan pelajaran yang dipelajarinya dengan suatu bentuk akhir yang sesuai dengan tingkat kemajuan berpikir anak. Pendidikan pada hakikatnya merupakan proses penemuan personal (personal discovery), oleh setiap individu murid. Inilah tema pokok teori Bruner. Belajar penemuan (discovery learning) merupakan salah satu model pembelajaran/belajar kognitif yang dikembangkan oleh Bruner (1966). Menurut Bruner belajar bermakna hanya dapat terjadi melalui belajar penemuan. Agar belajar menjadi bermakna dan memiliki struktur informasi yang kuat, siswa harus aktif mengidentifikasi prinsipprinsip kunci yang ditemukannya sendiri, bukan hanya sekedar menerima penjelasan dari guru saja. Gagne/Berliner, 319-320 dalam Winataputra 2008.

3) Teori belajar kognitif menurut Robert M. Gagne 
Salah satu teori belajar yang berasal dari psikologi kognitif adalah teori pemprosesan informasi (Information Processing Theory) yang dikemukakan Gagne (dalam Eveline Siregar dan Hartati Nara: 2014, hal.32-33). Menurut teori ini, belajar dipandang sebagai proses pengolahan informasi dalam otak manusia. Menurut Gagne dalam Winataputra (2008, hal.3.43) mengatakan bahwa belajar bukan merupakan proses yang tunggal, melainkan proses yang luas yang dibentuk oleh pertumbuhan dan perkembangan tingkah laku, yang merupakan hasil dari efek kumulatif belajar. Ia mendefinisikan belajar sebagai seperangkat proses kognitif yang dapat mengubah sifat stimulus dari lingkungan menjadi beberapa tahap pengolahan informasi untuk memperoleh kapasitas yang baru.

Sedangkan pengolahan otak manusia sendiri dapat dijelaskan sebagai berikut:

a) Receptor (alat-alat indra) menerima rangsangan dari lingkungan dan mengubahnya menjadi rangsangan neural, memberi simbol-simbol informasi yang diterimanya dan kemudian diteruskan.

b)Sensory register (menampung kesan-kesan sensoris) yang terdapat pada syaraf pusat, fungsinya menampung kesankesan sensoris dan mengadakan seleksi, sehingga terbentuk suatu kebukatan perseptual (persepsi selektif). Informasiinformasi yang masuk, sebagian diteruskan ke memori jangka pendek, sebagian hilang dari sistem.

c) Short-term memory (memori jangka pendek) menampung hasil pengolahan perseptual dan menyimpannya. Informasi tertentu disimpan lebih lama dan diolah untuk menentukan maknanya. Memori jangka pendek dikenal dengan memori kerja (working memory), kapasitasnya sangat terbatas, waktu penyimpanannya pendek.

d)Long-term memory (memori jangka panjang), menampung hasil pengolahan yang ada di memori jangka pendek. 
Informasi disimpan dalam jangka panjang dan bertahan lama, siap untuk dipakai bila diperlukan. Saat tranformasi informasi-informasi baru terintegrasi dengan informasiinformasi yang tersimpan. Pengeluaran kembali atas informasi-informasi yang tersimpan dalam memori jangka panjang adalah dengan pemanggilan.

e)Response generator (pencipta respons), menampung informasi dalam memori jangka panjang dan mengubahnya menjadi reaksi jawaban.

4) Teori Belajar Kognitif Ausubel

Teori belajar kognitif Ausubel dikenal juga sebagai teori belajar bermakna. Pembelajaran bermakna yaitu suatu proses mengkaitkan informasi baru konsep-konsep relevan yang terdapat dalam struktur kognitif seseorang. Dengan belajar bermakna, informasi (pengetahuan) yang diperoleh mempunyai daya tahan yang lebih lama. Pembelajaran di sekolah menjadi lebih efektif dan efisien. Banyak pembelajaran di beberapa tempat dengan menekankan pada belajar asosiatif. Pelaku pendidikan, guru maupun siswa, lebih menekankan pada hafalan materi. Untuk beberapa pelajaran, hal ini memang cocok, tetapi ada yang lebih bermakna dari ini. Karena belajar seharusnya merupakan asimilasi bagi siswa. Dalam hal ini siswa melebur dan bersatu dengan lingkungan belajarnya.

\section{TEORI BELAJAR HUMANISTIC}

Proses belajar Humanistik memusatkan perhatian kepada diri peserta didik sehingga menitikberatkan kepada kebebasan individu. Teori Humanistik menekankan kognitif dan afektif memengaruhi proses. Kognitif adalah aspek penguasaan ilmu pengetahuan sedangkan afektif adalah aspek sikap yang keduanya perlu dikembangkan dalam membangun individu. Belajar dianggap berhasil jika si pelajar memahami lingkungannya dan dirinya sendiri. Hal yang penting lagi pada proses pembelajaran Humanisme harus adanya motivasi yang diberikan agar peserta didik dapat terus menjalani 
pembelajaran dengan baik. Motivasi dapat berasal dari dalam yaitu berasal dari diri sendiri, maupun dari guru sebagai fasilitator. Adapun Tokoh-tokoh Humanistic sebagai berikut;

1. Abraham Maslow, didasarkan pada asumsi bahwa di dalam diri individu ada dua hal : (1) suatu usaha yang positif untuk berkembang. (2) kekuatan untuk melawan atau menolak perkembangan itu. Berkaitan dengan pendapat tersebut Maslow mengemukakan adanya 5 tingkatan kunci kebutuhan pokok manusia. Kelima tingkatan kebutuhan pokok inilah yang kemudian dijadikan pengertian kunci dalam mempelajari motivasi manusia. Karena sesungguhnya dalam teori humanistik ini sangat diperlukannya motivasi.

2. Carl Sam Rogers, mengemukakan Kebutuhan individu ada 4 yaitu : (1) pemeliharaan, (2) peningkatan diri, (3) penghargaan positif (positive regard) dan (4) Penghargaan diri yang positif (positive self-regard). Belajar yang paling berguna secara sosial di dalam dunia modern ini adalah belajar mengenai proses belajar, suatu keterbukaan yang terus menerus terhadap pengalaman dan penyatuannya ke dalam diri sendiri mengenai proses perubahan itu.

3. Arthur Combs, mengemukakan bahwa Belajar terjadi bila mempunyai arti bagi individu. Guru tidak bisa memaksakan materi yang tidak disukai atau tidak relevan dengan kehidupan mereka. Untuk mengerti tingkah laku manusia, yang penting adalah mengerti bagaimana dunia ini dilihat dari sudut pandangnya.

\section{E. TEORI BELAJAR KONSTRUKVISTIK}

Konstruktivisme berasal dari kata to construct yang artinya membangun atau menyusun. Menurut Von Glasersfeld, konstruktivisme merupakan salah satu filsafat pengetahuan yang menekankan bahwa pengetahuan kita adalah konstruksi (bentukan) kita sendiri. Pengetahuan dibentuk oleh struktur konsepsi seseorang sewaktu berinteraksi dengan lingkungan. Tujuan dari teori belajar ini adalah untuk menumbuhhkan motivasi peserta didik, mengembangkan motivasi dan kemampuan menjadi pemikir yang 
mandiri atau yang tidak harus distimulus terus. Konstruktivisme merupakan teori belajar yang mencoba menjelaskan bagaimana peserta didik belajar dengan membangun memahami untuk diri mereka sendiri. Bagian ini akan mengeksplorasi teori pembelajaran konstruktivisme dengan mendefinisikan konstruktivisme, memberikan berbagai pandangan konstruktivisme, dan menggambarkan bagaimana konstruktivisme berhubungan dengan pembelajaran mandiri dan pendidikan tinggi. (German: 2013). Adapun Tokoh-tokoh Teori Belajar Konstruktivisme sebagai berikut;

1. Jean Piaget, menyebutkan bahwa penekanan teori kontruktivisme pada proses adalah untuk menemukan teori atau pengetahuan yang dibangun dari realitas di kenyataan. Peran guru dalam pembelajaran menurut teori kontruktivisme adalah sebagai fasilitator atau moderator. Pandangan tentang anak dari kalangan konstruktivistik yang lebih mutakhir yang dikembangkan dari teori belajar kognitif Piaget menyatakan bahwa ilmu pengetahuan dibangun dalam pikiran seorang anak dengan kegiatan asimilasi dan akomodasi sesuai dengan skemata yang dimilikinya. Proses mengkonstruksi, sebagaimana dijelaskan Jean Piaget adalah sebagai berikut:

a)Skemata : Sekumpulan konsep yang digunakan ketika berinteraksi dengan lingkungan, proses membangun pemikiranpemikiran.

b)Asimilasi : Proses kognitif dimana seseorang mengintegrasikan persepsi, konsep ataupun pengalaman baru ke dalam skema atau pola yang sudah ada dalam pikirannya atau dapat dikatakan pula menghubungkan antara pengetahuan lama dengan pengetahuan baru.

c)Akomodasi. Akomodasi tejadi untuk membentuk skema baru yang cocok dengan rangsangan yang baru atau memodifikasi skema yang telah ada sehingga cocok dengan rangsangan itu.

d)Keseimbangan (Ekuilibrasi) adalah keseimbangan antara asimilasi dan akomodasi sedangkan diskuilibrasi adalah 
keadaan dimana tidak seimbangnya antara proses asimilasi dan akomodasi. Ekuilibrasi dapat membuat seseorang menyatukan pengalaman luar dengan struktur dalamnya.

2. Teori Piaget, terdiri dari (a) Pengurutan, (b) Klasifikasi, (c) Decentering (Membuat satu proyek kerja dengan melibatkan berbagai unsur), (d) Reversibility (kemampuan untuk mengeksplorasi dan membangun suatu kesimpulan, mengurai kemudian membangunnya lagi) dan (e)Penghilangan sifat egosentrisme

3. Vygotsky, peserta didik dalam mengkonstruksi suatu konsep perlu memperhatikan suatu lingkungan sosial. 2 konsep penting menurut Vygotsky :

a) Zone of Proximal Development (ZPD) adalah jarak antara level perkembangan aktual yang ditentukan melalui pemecahan masalah secara mandiri dan level potensi perkembangan yang ditentukan melalui pemecahan masalah dengan bantuan orang dewasa atau kerjasama dengan teman sebaya yang lebih mampu.

b) Scaffolding. Individu diberi bantuan secara bertahap dengan pengetahuan awalnya kemudian diberi dorongan, motivasi dan evaluasibserta penguraian masalah agar peserta didik lebih bertanggungjawab lebih besar lagi. 


\section{BAB VI \\ INTERAKSI SOSIAL DAN MOTIVASI BELAJAR}

Interaksi sosial dan motivasi belajar merupakan berbagai hal yang berhubungan dengan dunia perubahan dimana hal ini sangat berkaitan dengan hubungan antar individu, hubungan antara satu kelompok dengan kelompok yang lainnya saling memberi dan memotivasi baik lingkungan masyarakat khsusunya dunia pendidikan. Apabila tidak ada yang namanya interaksi sosial maka tidak akan terjadi proses belajar mengajar, yang bisa di pastikan jika dunia ini tidak akan ada namanya kehidupan bersama. Tak hanya itu saja, proses sosial adalah salah satu interaksi timbal balik atau yang sering disebut dengan hubungan yang saling mempengaruhi antara manusia satu dengan manusia yang lainnya dan saling mendukungan untuk meningkatkan prestasi-prestasi baik dalam lingkungan masyarakat maupun lingkungan sekolah khusunya di dalam kelas. Hubungan yang seperti ini akan berlangsung hingga seumur hidup di lingkungan masyarakat.

\section{A. INTERAKSI SOSIAL}

Interaksi adalah suatu jenis tindakan yang terjadi ketika dua atau lebih objek mempengaruhi atau memiliki efek satu sama lain. Ide efek dua arah ini penting dalam konsep interaksi, sebagai lawan dari hubungan satu arah pada sebab akibat. Kombinasi dari interaksiinteraksi sederhana dapat menuntun pada suatu fenomena baru yang mengejutkan. Dalam berbagai bidang ilmu, interaksi memiliki makna yang berbeda.

Interaksi adalah berbagai hubungan sosial yang berkaitan dengan hubungan antar individu, antar individu dengan kelompok serta kelompok dengan kelompok. Jika tidak ada interaksi sosial, maka di dunia ini tidak ada kehidupan bersama. Selain itu, proses sosial merupakan interaksi timbal balik atau disebut sebagai hubungan yang saling mempengaruhi antara manusia yang satu 
dengan lainnya dan hubungan ini berlangsung seumur hidup di masyarakat.

Interaksi sosial ialah suatu hubungan yang ada di antara dua atau bahkan lebih dari individu manusia. Yang mana perbuataan dari individu ini akan mengubah, mempengaruhi bahkan bisa memperbaiki kelakuan dari individu yang lainnya. interaksi sosial juga tidak sekedar berbicara mengenai tindakan tapi tindakanlah yang bisa mempengaruhi individu yang lainnya.

Interaksi sosial merupakan hubungan social yang dinamis antara individu dengan individu-individu dengan kelompok, dan kelompok dengan kelompok. Sebab interaksi hal saling melakukan aksi, berhubungan, mempengaruhin antarhubungan sosial hubungan sosial yang dinamis antara orang perse-orangan dan orang perseorangan, antara perseorangan dan kelompok, dan antara kelompok dan kelompok

Homans ( Ali, 2004: 87) mendefinisikan interaksi sebagai suatu kejadian ketika suatu aktivitas yang dilakukan oleh seseorang terhadap individu lain diberi ganjaran atau hukuman dengan menggunakan suatu tindakan oleh individu lain yang menjadi pasangannya. Interaksi adalah suatu tindakan yang dilakukan oleh seseorang dalam interaksi merupakan suatu stimulus bagi tindakan individu lain yang menjadi pasangannya.

Oleh karena itu, Interaksi menurut beberapa ahli tersebut dapat disimpulkan bahwa, interaksi adalah hubungan timbal balik anatara dua orang atau lebih, dan masing-masing orang yang terlibat di dalamnya memainkan peran secara aktif. Dalam interaksi juga lebih dari sekedar terjadi hubungan antara pihak- pihak yang terlibat melainkan terjadi saling mempengaruhi.

\section{B. INTERAKSI GURU DAN SISWA}

Proses belajar mengajar yang dilakukan di kelas selama ini seringkali satu arah dimana siswa hanya mendengarkan apa yang disampaikan guru. Oleh karenanya, siswa lebih dilibatkan secara aktif 
untuk berinteraksi dengan guru atau antar siswa. Prosentase kemampuan siswa/mahasiswa dalam memahami dan mengingat materi apa yang telah dipelajari sebelumnya hanya 5\% jika mereka sekadar mendengarkan penjelasan guru/dosen. Oleh karena itu, hubungan seperti ini terkedan terjadi antara guru dan siswa seringkali satu arah dimana siswa hanya sekadar mendengarkan apa yang disampaikan guru. "Jika dilihat dari piramida pembelajaran, siswa akan mudah lupa dengan apa yang dipelajari sebelumnya ketika mereka hanya mendengarkan penjelasan guru/dosen.

Interaksi juga menjadi poin penting dalam kegiatan belajar mengajar karena tak hanya siswa saja yang mendapatkan manfaat, namun juga para guru juga memperoleh umpan balik (feedback) apakah materi yang disampaikan dapat diterima murid dengan baik. "Untuk itu, mendengar pengalaman para siswa dapat diaplikasikan dalam metode pembelajaran sebelum guru masuk ke dalam penjelasan teori dan setelah perkenalan," jelasnya.

Lebih lanjut, Ia menguraikan empat karakteristik siswa yang terdiri dari siswa yang termotivasi oleh profesi, balasan, sosial, dan siswa yang memang memiliki minat besar dalam bidangnya. "Sayangnya, karakteristik siswa terakhir ini bisa dibilang jumlahnya sedikit dan menjadi minoritas diantara karakteristik yang lain. Oleh karenanya, pada awal studi tersebut, para siswa perlu didorong dan diberikan semangat untuk mempelajari materi yang diberikan," urai Harry.

Model interaksi itu sendiri terdiri atas dua kata, Model dan Interaksi, model dalam kamus bahasa indonesia berarti contoh, pola acuan ragam, macam. Model adalah suatu gambaran tentang suatu yang dapat memperjelas berbagai kaitan diantara unsur-unsur yang ada. Sedangkan interaksi adalah interaksi terdiri atas dua kata asal, yaitu aksi dan interaksi adalah kegiatan, sedangkan inter dapat diterjemahkan menjadi antar. Interaksi adalah kegiatan timbal balik, kegiatan yang satu menimbulkan kegiatan yang lain, kegiatan satu partner menyebabkan kegiatan partner yang lainnya. Satu sama lain 
saling merangsang kegiatan yang ditimbulkan oleh kedua pasangan. Kalau yang menjadi masalah adalah interaksi belajar mengajar, maka berarti ada kegiatan murid dan kegiatan guru. Kegiatan keduanya menyebabkan pengaruh satu sama lain, kegiatan yang satu bertumpu dan menjawab kegiatan dari yang lainnya.

Proses belajar mengajar adalah proses penyampaian pelajaran yang dilakukan oleh guru kepada peserta didiknya, atau disebut juga proses transfer, mentransfer pelajaran dari pendidik kepada perta didik. Di dalam al-Qur'an dijelaskan juga tentang mengajar, Guru sebagai pengajar, guru bertugas memberikan pengajaran disekolah. Ia menyampaikan pelajaran agar siswa memahami dengan baik semua pengetahuan yang telah disampaikannya itu. Dalam proses belajar mengajar tidak terlepas dari interaksi, tanpa adanya interaksi di dalamnya proses belajar mengajar tidak akan berjalan dengan baik. Interaksi ini akan terlaksana jika ada hubungan yang baik antara guru dengan siswanya. Semua komponen dalam sistem pembelajaran haruslah saling berhubungan satu sama lain. Untuk menciptakan hubungan yang baik antara guru dengan siswa, maka seorang guru hendaknya dalam berinteraksi menggunakan model interaksi yang bisa membuat siswa lebih aktif, sehingga proses pembelajaran berjalan dengan baik.

Dari uraian pengertian di atas, dapat penulis tarik kesimpulan bahwa model interaksi dalam proses pembelajaran merupakan suatu aksi yang dilakukan oleh seorang guru dalam menyampaikan pelajaran hingga terjalinnya hubungan yang harmonis (timbal balik) antara guru dengan siswa dan siswa antar siswa.

\section{PENGERTIAN MOTIVASI}

Motivasi adalah suatu dorongan atau alasan yang menjadi dasar semangat seseorang untuk melakukan sesuatu untuk mencapai tujuan tertentu. Arti motivasi juga dapat didefinisikan sebagai semua hal yang menimbulkan dorongan atau semangat di dalam diri seseorang untuk mengerjakan sesuatu. 
Secara etimologi kata motivasi berasal dari bahasa Inggris, yaitu "motivation", yang artinya "daya batin" atau "dorongan". Sehingga pengertian motivasi adalah segala sesuatu yang mendorong atau menggerakkan seseorang untuk bertindak melakukan sesuatu dengan tujuan tertentu. Motivasi bisa datang dari dalam diri sendiri ataupun dari orang lain. Dengan adanya motivasi maka seseorang dapat mengerjakan sesuatu dengan antusias.

1. Weiner (dikutip Elliot Et Al.) pengertian motivasi adalah kondisi internal yang membangkitkan seseorang untuk bertindak, mendorong individu mencapai tujuan tertentu, dan membuat individu tetap tertarik dalam kegiatan tertentu.

2. Uno, arti motivasi adalah dorongan internal dan eksternal dalam diri seseorang yang diindikasikan dengan adanya; hasrat dan minat; dorongan dan kebutuhan; harapan dan cita-cita; penghargaan dan penghormatan.

3. Henry Simamora pengertian motivasi adalah sebuah fungsi dari pengharapan individu bahwa upaya tertentu akan menghasilkan tingkat kinerja yang pada gilirannya akan membuahkan imbalan atau hasil yang dikehendaki.

4. A. Anwar Prabu Mangkunegara definisi motivasi adalah suatu kondisi yang berpengaruh membangkitkan, mengarahkan dan memelihara perilaku yang berubungan dengan lingkungan kerja.

5. G. R. Terry pengertian motivasi adalah sebuah keinginan yang ada pada diri seseorang yang merangsangnya untuk melakukan berbagai tindakan.

Motivasi adalah proses yang menjelaskan intensitas, arah, dan ketekunan seorang individu untuk mencapai tujuannya. Tiga elemen utama dalam definisi ini diantaranya adalah intensitas, arah, dan ketekunan.

Dari penjelasan diatas dapat disimpulkan bahwa motivasi merupakan suatu proses yang mendorong atau mempengaruhi seseorang untuk mendapatkan atau mencapai apa yang diinginkannya baik itu secara positif maupun negatif. Motivasi akan memberikan 
perubahan pada seseorang yang muncul akibat dari perasaan, jiwa dan emosi sehingga mendorong untuk melakukan tindakan sesuatu yang disebabkan karena kebutuhan, keinginan dan tujuan tersebut.

\section{JENIS DAN SUMBER MOTIVASI}

Pembagian jenis motivasi dapat dilihat dari perspektif kebutuhan dan perspektif fungsional.

1. Perspektif kebutuhan, pada dasarnya kebutuhan manusia itu bertingkat-tingkat dan individu akan puas bila dapat memenuhi kebutuhan pada taraf tertentu sebelum taraf kebutuhan tersebut di penuhi. Berikut beberapa kebutuhan manusia :

a) Kebutuhan fisiologis : kebutuhan dasar yang harus dipenuhi sebelum kebutuhan lainnya terpenuhi seperti kebutuhan untuk istirahat, makan dan minum.

b) Jenis Kebutuhan keamanan (security) : kebutuhan akan rasa terlindungi serta terbebas dari rasa takut dan kecemasan.

c) Jenis Kebutuhan sosial : kebutuhan kash sayang seperti perasaann untuk dihargai dan dihormati oleh orang lain.

d) Kebutuhan dirinya sendiri : kebutuhan ini terkait dengan pengembangan bakat dan minat yang dimiliki manusia baik di dalam bidang pengetahuan, sosial, dll.

2. Perspektif Fungsional, ini membagi jenis motivasi berdasarkan dari konsep motivasi sebagai penggerak, harapan dan insentif.Jenis motivasi yang didasarkan sebagai penggeraka dalah motivasi yang dapat memberikan tenaga pada kegiatan tertentu. Artinya kegiatan ini hanya dapat terjadi bila terdapat faktor pendororng untuk menggerakkan seluruh energi yang ada. Motivasi yang didasarkan pada harapan adalah jenis motivasi yang memandang bahwa sesuatu pasti akan terjadi sesuai dengan harapan. Oleh sebab itu, jenis motivasi ini dapat timbul karena adanya harapan yang dapat memuaskan kebutuhannya. Bila seseorang tidak memiliki harapan bahwa sesuatu tersebut tidak terjadi sesuai dengan harapan maka motivasi dirinya juga akan menurun bahkan hilang. Sedangan motivasi yang di dasarkan pada insentif adalah motivasi yang 
timbul karena adanya tujuan yang nyata. Tujuan tersebut dapat berupa rasa bahagia atau senang misalkan adanya hadiah ataupun pujian.Oleh sebab itu seseorang dapat di motivasi dengan memberikan insentif kepadanya.

Motivasi dapat terbagi menjadi dua yaitu motivasi intrinsik dan motivasi ekstrinsik. Schunk (2012) menyatakan bahwa motivasi intrinsic mengacu pada motivasi yang melibatkan diri dalam sebuah aktivitas karena nilai/manfaat aktifitas itu sendiri (aktifitas itu sendiri merupakan sebuah tujuan akhir). Individu-individu yang termotivasi secara intrinsic mengerjakan tugas-tugas tersebut menyenangkan. Partisipasi pengerjaan tugas merupakan penghargaan yang didapatkan dari pengerjaan tugas itu sendiri dan tidak bergantung pada penghargaan eksplisit atau pembatas ekternal lain. Motivasi ekstrinsik adalah motivasi melibatkan diri dalam sebuah aktifitas sebagai suatu cara mencapai sebuah tujuan. Individu-individu yang termotivasi secara ekstrinsik mengerjakan tugas-tugas karena mereka meyakini bahwa partisipasi tersebut akan menyebabkan berbagai konsekwensi yang diinginkan, seperti mendapatkan hadiah, menerima pujian dari guru, atau terhindar dari hukuman.

Sumber motivasi dapat dibagi menjadi 2 (dua) golongan yaitu sumber motivasi yang berasal dari dalam diri (intrinsik) dan sumber motivasi yang berasal dari luar diri (ekstrinsik)

1. Motivasi intrinsic, merupakan motif yang menjadi aktif atau berfungsinya tidak membutuhkan pengaruh dari luar karena di dalam diri manusia sudah terdapat dorongan untuk melakukan sesuatu. Oleh sebab itu, motivasi intrinsik sering juga disebut sebagai bentuk motivasi yagn dimulai atas dasar dorongan dari dalam diri.

2. Motivasi Ekstrinsik, merupakan motif yagn aktif dan berfungsi karena adanya pengaruh dari luar diri.Sumber motivasi ekstrinsik ini juga dapat dikatakan motivasi yang timbul karena dorongan dari luar yang tidak terkait dengan dirinya. 
Berangkat dari teori-teori motivasi tersebut di atas, dapat dikatakan bahwa motivasi merupakan suatu dorongan yang timbul oleh adanya rangsangan dari dalam maupun dari luar sehingga seseorang berkeinginan untuk mengadakan perubahan tingkah laku tertentu yang lebih baik dari sebelumnya.

\section{E.PERAN MOTIVASI DALAM BELAJAR DAN PEMBELAJARAN}

Dalam kegiatan belajar, motivasi dapat dikatakan sebagai keseluruhan daya penggerak di dalam diri siswa yang menimbulkan, menjamin kelangsungan dan memberikan arah kegiatan belajar, sehingga diharapkan tujuan dapat tercapai. Dalam kegiatan belajar, motivasi sangat diperlukan, sebab seseorang yang tidak mempunyai motivasi dalam belajar, tidak akan mungkin melakukan aktivitas belajar.

Pentingnya peranan motivasi dalam proses pembelajaran perlu dipahami oleh pendidik agar dapat melakukan berbagai bentuk tindakan atau bantuan kepada siswa. Motivasi dirumuskan sebagai dorongan, baik diakibatkan faktor dari dalam maupun luar siswa, untuk mencapai tujuan tertentu guna memenuhi atau memuaskan suatu kebutuhan. Dalam konteks pembelajaran maka kebutuhan tersebut berhubungan dengan kebutuhan untuk belajar. Teori behaviorisme menjelaskan motivasi sebagai fungsi rangsangan (stimulus) dan respons, sedangkan apabila dikaji menggunakan teori kognitif, motivasi merupakan fungsi dinamika psikologis yang lebih rumit, melibatkan kerangka berpikir siswa terhadap berbagai aspek perilaku

Di dalam kegiatan belajar, peran motivasi sangat diperlukan. Peran dari motivasi belajar tersebut adalah dapat menumbuhkan gairah, dan juga semangat dalam menjalani proses kegiatan belajar. Dengan motivasi ini, peserta didik dapat mengembangkan aktivitas dan inisiatifnya, dan juga dapat mengarahkan serta memelihara ketekunan dalam melakukan kegiatan belajar. Seorang pendidik harus berhati-hati dalam menumbuhkan dan memberi motivasi bagi 
kegiatan belajar peserta didiknya. Karena, cara dan jenis menumbuhkan motivasi itu bermacam-macam. Ada beberapa bentuk dan cara untuk menumbuhkan motivasi dalam kegiatan belajar, diantaranya memberi angka, angka dalam hal ini sebagai simbol dari hasil kegiatan belajar peserta didik.

Mengenai angka ini, terutama angka-angka yang baik akan memacu peserta didik untuk melakukan kegiatan-kegiatan yang positif, terutama dalam proses pembelajaran. Tetapi ada juga, peserta didik dalam kegiatan belajar hanya ingin mengejar naik kelas saja, ini menunjukkan bahwa motivasi yang dimiliki oleh peserta didik tersebut kurang berbobot jika dibandingkan dengan peserta didik yang menginginkan angka yang terbaik. Bentuk dan cara menumbuhkan motivasi yang lainnya adalah pujian. Apabila ada peserta didik yang sukses dalam menyelesaikan tugasnya, perlu pendidik memberikan pujian terhadap peserta didik tersebut. Pujian ini sekaligus merupakan motivasi yang sangat baik, karena pujian ini akan membuat kepercayaan diri peserta didik menjadi lebih baik dari sebelumnya.

Oleh karena itu, agar pujian ini menjadi sebuah motivasi, pemberiannya pun tidak sembarangan, sehingga nantinya pujian ini menjadi sebuah motivasi yang baik bagi peserta didiknya, dan juga dapat memberikan suasana yang menyenangkan, dan yang terpenting membangkitkan gairah belajar peserta didik.

\section{F. UNSUR-UNSUR YANG MEMPENGARUHI MOTIVASI BELAJAR}

Unsur-unsur yang mempengaruhi motivasi belajar adalah:

1. Cita-cita atau aspirasi siswa. Motivasi belajar tampak pada keinginan anak sejak kecil. Keberhasilan mencapai keinginan tersebut menumbuhkan kemauan bergiat, bahkan dikemudian hari cita-cita dalam kehidupan. Dari segi emansipasi kemandirian, keinginan yang terpuaskan dapat memperbesar kemauan dan semangat belajar. Dari segi pembelajaran, penguatan dengan hadiah atau juga hukuman akan dapat 
mengubah keinginan menjadi kemauan, dan kemudian kemauan menjadi cita-cita.

2. Kemampuan siswa. Keinginan seorang anak perlu dibarengi dengan kemampuan atau kecakapan mencapainya. Kemampuan akan memperkuat motivasi anak untuk melaksanakan tugastugas perkembangan.

3. Kondisi siswa. Kondisi siswa yang meliputi kondisi jasmani dan rohani sangat mempengaruhi motivasi belajar.

4. Kondisi lingkungan siswa Lingkungan siswa berupa keadaan alam, lingkungan tempat tinggal, pergaulan sebaya, kehidupan kemasyarakatan. Dengan kondisi lingkungan tersebut yang aman, tentram, tertib dan indah maka semangat dan motivasi belajar mudah diperkuat.

5. Unsur-unsur dinamis dalam belajar dan pembelajaran. Siswa memiliki perasaan, perhatian, kemauan, ingatan, pikiran yang mengalami perubahan berkat pengalaman hidup. Pengalaman dengan teman sebayanya berpengaruh pada motivasi dan perilaku belajar.

Upaya guru dalam membelajarkan siswa. Guru adalah seorang pendidik profesional. Ia bergaul setiap hari dengan puluhan atau ratusan siswa. Sebagai pendidik, guru dapat memilil dan memilah yang baik. Partisipasi dan teladan memilih perilaku yang baik tersebut sudah merupakan upaya membelajarkan dan memotivasi siswa. Dalam hal ini guru harus mampu untuk mengendalikan kelas yang dipegangnya. Adapun yang harus diperhatikan sebagai seorang guru adalah sebagai berikut:

1. Kedisiplinan Guru: Kedisiplinan guru memiliki pengaruh terhadap prilaku belajar siswa. Guru yang berdisiplin dalam mengajar cenderung lebih diperhatikan dan dihormati oleh siswanya. Kedisiplinan seorang guru dapat dilihat dari: (a) Menyelenggarakan tertib belajar di sekolah, (b) Membina disiplin belajar dalan tiap kesempatan, seperti pemnafaatan waktu dan pemeliharaan fasilitas sekolah dan, (c) Mematuhi tata 
tertib sekolah: Masalah disiplin merupakan suatu hal yang penting bagi seorang guru, tanpa ada kedisiplinan yang besar didalam diri guru maka alam kelabu akan selalu menutupi dunia pendidikan dan pengajaran.

2. Kepribadian Guru: Kepribadian seorang guru adalah kemampuan yang melekat dalam diri pedidik secara mantap, stabil, dewasa, arif dan berwibawa, menjadi teladan bagi anak didik dan berakhlak mulia. Jika seorang guru mampu menunjukkan pribadi yang baik, maka akan berpengaruh terhadap kebiasaan dan motivasi belajar siswa. Siswa merasa diperhatikan dan dilibatkan ketika proses belajar mengajar berlangsung.

\section{GU UPAYA-UPAYA MEMOTIVASI DALAM BELAJAR}

Proses pembelajaran akan berhasil manakala siswa mempunyai motivasi dalam belajar. Oleh karena itu, guru perlu menumbuhkan motivasi belajar siswa. Untuk memperoleh hasil belajar yang optimal, guru dituntut kreatif membangkitkan motivasi belajar siswa. Berikut ini dikemukakan beberapa petunjuk untuk meningkatkan motivasi belajar siswa.

1. Memperjelas tujuan yang ingin dicapai.

Tujuan yang jelas dapat membuat siswa paham kearah mana ia ingin dibawa. Pemahaman siswa terhadap tujuan pembelajaran dapat menumbuhkan minat siswa untuk belajar yang pada gilirannya dapat meningkatkan motivasi belajar mereka. Semakin jelas tujuan yang ingin dicapai, maka akan semakin kuat motivasi nbelajar siswa (Sanjaya, 2009:29). Oleh sebab itu, sebelum proses pembelajaran dimulai hendaknya guru menjelaskan terlebih dahulu tujuan yang ingin dicapai.

2. Membangkitkan minat siswa

Siswa akan terdorong untuk belajar manakala mereka memiliki minat untuk belajar. Oleh karena itu, mengembangkan minat belajar siswa merupakan salah satu teknik dalam mengembangkan motivasi belajar (Sanjaya, 2009:29). Salah satu 
cara yang logis untuk momotivasi siswa dalam pembelajaran adalah mengaitkan pengalaman belajar dengan minat siswa (Djiwandono, 2006:365). Pengaitan pembelajaran dengan minat siswa adalah sangat penting, dan karena itu tunjukkanlah bahwa pengetahuan yang dipelajari itu sangat bermanfaat bagi mereka. Demikian pula tujuan pembelajaran yang penting adalah membangkitkan hasrat ingin tahu siswa mengenai pelajaran yang akan datang, dan karena itu pembelajaran akan mampu meningkatkan motivasi instrinsik siswa untuk mempelajari materi pembelajaran yang disajikan oleh guru (Anni, dkk., 2006:186).

3. Ciptakan suasana yang menyenangkan dalam belajar Siswa hanya mungkin dapat belajar baik manakala ada dalam suasana yang menyenangkan, merasa aman, bebas dari takut. Usahakan agar kelas selamanya dalam suasana hidup dan segar, terbebas dari rasa tegang. Untuk itu guru sekali-kali dapat melakukan hal-hal yang lucu.

4. Mengguanakan variasi metode penyajian yang menarik

Guru harus mampu menyajikan informasi dengan menarik, dan asing bagi siswa-siswa. Sesuatu informasi yang disampaikan dengan teknik yang baru, dengan kemasan yang bagus didukung oleh alat-alat berupa sarana atau media yang belum pernah dikenal oleh siswa sebelumnya sehingga menarik perhatian bagi mereka untuk belajar (Yamin, 2009:174). Dengan pembelajaran yang menarik, maka akan membangitkan rasa uingin tahu siswa di dalam kegiatan pembelajaran yang selanjutnya siswa akan termotivasi dalam pembelajaran.

5. Berilah pujian yang wajar setiap keberhasilan siswa

Motivasi akan tumbuh manakala siswa merasa dihargai. Dalam pembelajaran, pujian dapat dimanfaatkan sebagai alat motivasi. Karena anak didik juga manusia, maka dia juga senang dipuji. Karena pujian menimbulkan rasa puas dan senang (Sanjaya, 2009:30 ; Hamalik, 2009:167). 
6. Berikan penilaian

Banyak siswa yang belajar karena ingin memperoleh nilai bagus. Untuk itu mereka belajar dengan giat. Bagi sebagian siswa nilai dapat menjadi motivasi yang kuat untuk belajar. Oleh karena itu, penilaian harus dilakukan dengan segera agar siswa secepat mungkin mengetahui hasil kerjanya. Penilaian harus dilakukan secara objektif sesuai dengan kemampuan siswa masing-masing (Sanjaya, 2009:31).

Disamping beberapa petunjuk cara membangkitkan motivasi belajar diatas, adakalanya motivasi itu juga dapat dibangkitkan dengan cara-cara lain yang sifatnya negatif seperti memberikan hukuman, teguran dan kecaman, memberikan tugas yang sedikit berat dan menantang (Sanjaya, 2009:31). Namun, teknik-teknik semacam itu hanya bisa digunakan dalam kasus tertentu. Beberapa ahli mengatakan dengan mmemmbangkitkan motivasi dengan cara-cara negatif lebih banyak merugikan siswa. Untuk itulah seandainya masih bisa dengan cara-cara yang positif, sebaiknya membangkitkakn motivasi dengan cara negatif dihindari. 


\section{BAB VII \\ PENDEKATAN PEMBELAJARAN}

\section{A. PENDEKATAN, STRATEGI, DAN METODE}

\section{Pendekatan}

Pendekatan dapat diartikan sebagai titik tolak atau sudut pandang kita terhadap proses pembelajaran. Pendekatan yang berpusat pada guru menurunkan strategi pembelajaran langsung (direct instruction), pembelajaran deduktif atau pembelajaran ekspositori. Sedangkan, pendekatan pembelajaran yang berpusat pada siswa menurunkan strategi pembelajaran discovery dan inkuiri serta strategi pembelajaran induktif (Sanjaya, 2008:127).

\section{Strategi}

Strategi pembelajaran dapat diartikan sebagai perencanaan yang berisi tentang rangkaian kegiatan yang didisain untuk mencapai tujuan pendidikan tertentu (J.R. David dalam Sanjaya, 2008:126). Selanjutnya dijelaskan strategi pembelajaran adalah suatu kegiatan pembelajaran yang harus dikerjakan guru dan siswa agar tujuan pembelajaran dapat dicapai secara efektif dan efisien (Kemp dalam Sanjaya, 2008:126). Istilah strategi sering digunakan dalam banyak konteks dengan makna yang selalu sama. Dalam konteks pengajaran strategi bisa diartikan sebagai suatu pola umum tindakan guru-peserta didik dalam manifestasi aktivitas pengajaran (Ahmad Rohani, 2004 : 32). Sementara itu, Joyce dan Weil lebih senang memakai istilah model-model mengajar daripada menggunakan strategi pengajaran (Joyce dan Weil dalam Rohani, 2004:33.

Berdasarkan pendapat di atas, dapat diambil kesimpulan bahwa strategi pembelajaran harus mengandung penjelasan tentang metode/prosedur dan teknik yang digunakan selama proses pembelajaran berlangsung. Dengan kata lain, strategi pembelajaran mempunyai arti yang lebih luas daripada metode dan teknik. 
Artinya, metode/prosedur dan teknik pembelajaran merupakan bagian dari strategi pembelajaran.

\section{Metode}

Metode merupakan jabaran dari pendekatan. Satu pendekatan dapat dijabarkan ke dalam berbagai metode. Metode adalah prosedur pembelajaran yang difokuskan ke pencapaian tujuan. Teknik dan taktik mengajar merupakan penjabaran dari metode pembelajaran.

\section{Pendekatan pembelajaran}

Dapat diartikan sebagai titik tolak atau sudut pandang kita terhadap proses pembelajaran, yang merujuk pada pandangan tentang terjadinya suatu proses yang sifatnya masih sangat umum, di dalamnya mewadahi, menginsiprasi, menguatkan, dan melatari metode pembelajaran dengan cakupan teoretis tertentu. Dilihat dari pendekatannya, pembelajaran terdapat dua jenis pendekatan, yaitu: (1) pendekatan pembelajaran yang berorientasi atau berpusat pada siswa (student centered approach) dan (2) pendekatan pembelajaran yang berorientasi atau berpusat pada guru (teacher centered approach).

Dari pendekatan pembelajaran yang telah ditetapkan selanjutnya diturunkan ke dalam Strategi Pembelajaran. Newman dan Logan (Abin Syamsuddin Makmun, 2003) mengemukakan empat unsur strategi dari setiap usaha, yaitu:

a. Mengidentifikasi dan menetapkan spesifikasi dan kualifikasi hasil (out put) dan sasaran (target) yang harus dicapai, dengan mempertimbangkan aspirasi dan selera masyarakat yang memerlukannya.

b. Mempertimbangkan dan memilih jalan pendekatan utama (basic way) yang paling efektif untuk mencapai sasaran.

c. Mempertimbangkan dan menetapkan langkah-langkah (steps) yang akan dtempuh sejak titik awal sampai dengan sasaran.

d. Mempertimbangkan dan menetapkan tolok ukur (criteria) dan patokan ukuran (standard) untuk mengukur dan menilai taraf keberhasilan (achievement) usaha. 
Jadi, metode pembelajaran di sini dapat diartikan sebagai cara yang digunakan untuk mengimplementasikan rencana yang sudah disusun dalam bentuk kegiatan nyata dan praktis untuk mencapai tujuan pembelajaran. Terdapat beberapa metode pembelajaran yang dapat digunakan untuk mengimplementasikan strategi pembelajaran, diantaranya: (1) ceramah; (2) demonstrasi;
(3) diskusi;
(4) simulasi;
(5) laboratorium;
(6) pengalaman lapangan; (7) brainstorming; (8) debat, (9) simposium, dan sebagainya.

\section{B. JENIS-JENIS METODE PEMBELAJARAN DAN PENERAPANNYA}

1. Pengajaran dengan berbantuan Komputer ( CAI:Computer Assisted Instruction) Setiap siswa menggunakan sebuah komputer untuk mempelajari suatu materi pelajaran. Contoh : Para siswa, diharuskan mengerjakan suatu makalah dengan mengunakan komputer yang ada di sekolah tersebut, dan dengan bimbingan dari gurunya, agar para siswa tidak mengalami kesulitan.

2. Dalam kegiatan pembelajaran menggunakan demonstrasi, guru memperagakan atau menunjukkan cara mengerjakan suatu prosedur, cara bekerjanya suatu prinsip, cara menggunakan suatu peralatan, dsb. Contoh : Guru memperagakan bagaimana Ir. Soekarno dalam membacakan teks proklamasi pada tanggal 17 Agustus 1945.

3. Metode pembelajaran yang hendaknya siswa mengamati secara teliti obyek studi atau materi yang dipelajari dengan tujuan agar siswa mendapatkan gambaran dan pengertian yang jelas. Contoh : Siswa mengamati bagaimana perilaku para penghuni Lembaga Permasyarakatan, dengan bimbingan dari para gurunya.

4. Metode mengajar yang menghendaki sekelompok siswa ( 3 orang atau lebih) membahas suatu masalah ditinjau dari berbagai segi atau sudut pandang. Contoh : Siswa membahas 
tentang masalah Pemilihan Umum yang langsung, umum, bebas, dan Rahasia, serta Jujur dan Adil.

5. Metode pembelajaran dimana siswa baik secara individual atau kelompok dilatih, di satu pihak untuk mengemukkan suatu pendapat terhadap suatu persoalan, sedangkan kelompok lain untuk mengemukakan bantahan, sanggahan, atau pendapat yang berbeda, dengan disertai alasan. Contoh : Sekelompok siswa mempresentasikan suatu masalah didepan kelasnya, lalu kelompok lain memberikan pendapat yang lain, sehingga akan terjadi perdebatan yang sengit.

6. Metode mengajar dimana sekelompok siswa ditugasi memerankan atau membawakan suatu cerita baik cerita fiktif maupun cerita sejarah. Contoh : Siswa disuruh memerankan bagaimana para pendiri bangsa ini dalam mengadakan rapat untuk perencanaan proklamasi kemerdekaan.

7. Kegiatan belajar dengan berlatih secara teratur, berulangkali, dan intensif dengan maksud membantu siswa menguasai keterampilan ( skills ) tertentu. Contoh : Siswa ditugasi belajar bagaimana, cara bergaya bagai seorang guru agar nantinya kelak jika ia akan menjadi guru.

8. Kegiatan belajar yang menghendaki siswa memberikan perlakuan ( treatment ) yang berbeda-beda terhadap suatu obyek atau subyek untuk diamati ada tidaknya pengaruh atau ada tidaknya perbedaan pengaruh perlakuan tadi. Contoh : Para siswa ditugasi mengamati kebijakan-kebijakan para politisi apakah kebijakan tersebut berpengaruh bagi masyarakat Indonesia.

9. Kegiatan belajar secara langsung praktek di lapangan kerja yang sesungguhnya. Contoh : Para siswa disuruh mengamati secara langsung bagaimana proses pembuatan Peraturan Daerah,agar lebih jelas.

10. Kegiatan belajar yang menghendaki siswa berkompetensi atau berlomba baik secara fisik maupun mental sesuai dengan aturan permainan yang telah ditetapkan. Contoh : Guru di dalam kelas 
mengadakan tebak tepat menghafalkan isi dari pasal-pasal yang ada dalam UUD 1945 dan rumusan Pancasila.

11. Metode pembelajaran dimana siswa melakukan kegiatan bukan dalam bentuk pembelajaran di kelas secara klasikal, melainkan dengan jalan melakukan berbagai kegiatan seperti konsultasi dengan guru, instruktur, nara sumber, dalam rangka menyelesaikan tugasnya. Contoh : Siswa dianjurkan untuk berlatih konsultasi mengenai berbagai problem pelajaran yang belum dimengerti siswa dan siswa juga disuruh membuat contoh penerapan dari metode-metode pembelajaran.

12. Kegiatan belajar yang dilaksanakan dalam suatu laboratorium direncanakan untuk suatu kelompok siswa yang mempelajari suatu bidang studi tertentu termasuk memperaktekkan teori teori dengan melalui pengamatan, percobaan, riset, mempelajari bahasa asing, termasuk didilamnya belajar dengan jalan demonstrasi, latihan ( drill ) dan praktikum. Contoh : Siswa ditugasi untuk mengamati berbagai kejadian fenomena tentang pembuatan peraturan perundang-undangan dalam gedung DPR/MPR melalui gambar atau foto yang telah ada dalam Laboratorium PPKn.

13. Suatu metode pembelajaran dimana guru atau instruktur menyajikan materi pelajaran secara lisan mengenai suatu fakta atau dalil dalil atau prinsip. Siswa mengikuti pelajaran dengan mendengarkan dan mencatat Contoh : siswa dianjurkan untuk dilatih berbicara di depan kelas sebagai seorang guru untuk menerangkan suatu topic.

14. Siswa melaksanakan dengan cara mendengarkan. Contoh : siswa dilatih mendengarakan radio dan melihat siaran TV, kemudian siswa disuruh menarik kesimpulan dan analisis dari berita media tersebut.

15. Kegiatan belajar diamana siswa menggunakan gerakan berbagai anggota badan dan syaraf peraba untuk mengembangkan keterampilam membentuk dan melatih kepekaan syaraf 
perabanya Contoh : Dalam hal ini siswa dianjurkan untuk membuat potongan gambar seorang tokoh atau lambang Negara, kemudian disuruh untuk menyusun potongan tersebut menjadi utuh kembali.

16. Kegiatan belajar dimana siswa ditunjukkan suatu model yang baik untuk dijadikan contoh atau teladan untuk ditiru pelakunya Contoh : Siswa disuruh melakukan dan mempraktekkan perilaku yang baik dari salah seorang tokoh yang dipelajari dan dari berbagai sumber.

17. metode pembelajaran dimana materi pelajaran disampaikan oleh beberapa orang yang memiliki keahlian dibidang masing masing dalam suatu forum Contoh : Dalam pembelajaran seorang guru di dalam kelas mengahadirkan seorang pembicara dari DPRD tentang pembuatan dan contoh pembutan Perda untuk menerangkan kepada siswa agar lebih jelas.

18. Kegiatan belajar dimana sisiwa diberi kesempatan untuk mempraktekkan pengetahuan pemahaman dan keterampilan yang diperleh dikelas contoh : Guru menyuruh siswa untuk terjun ke lapangan, setelah terlebih dahulu mendapatkan teori tentang pembuatan dan perpanjagan KTP atau SIM, kemudian siswa tersebut disuruh mempraktekkan sendiri ke lapangan agar lebih jelas dan paham betul.

19. Metode pembelajaran dimana siswa diminta untuk berlatih memecahkan masalah secara sistimatis Contoh : Siswa disuruh mencari suatu masalah dalam pendidikan, lalu dianalisis dan dibahas sehingga siswa dapat meemcahkan masalah itu sendiri dengan bimbingan dari gurunya terlebih dahulu.

20. Metode pembelajaran dimana materi pelajaran disajikan sedikit demi sedikit menurut urutan sistematis Contoh : seorang guru dalam memberikan materi tentang pelajaran Ilmu Sejarah, maka ia harus terlebih dahulu memberikan dasar-dasarnya terlebih dahulu, yakni dasar-dasar ilmu Sejarah. 
21. Teknik mengajar dimana siswa diberikan suatu pelajaran secara individu dalam bentuk bantuan belajar Contoh : Guru menyuruh siswa di dalam kelas untuk membentuk sustu kelompok kecil, kemudian guru memberikan pembimbing pada kelompok tersebut untuk memberikan pengarahan tentang materi agar bisa terjadi interaksi antara pembimbing dan siswa.

22. Teknik mengajar dimana materi pelajaran disajikan dengan menggunakan program siaran TV, siswa menerima pelajaran dengan jalan menonton TV. Contoh : Dalam hal ini guru dalam memberikan pengajaran kepada siswa, siswa dianjurkan melihat suatu masalah atau berita di media TV, kemudian disuruh untuk menyimpulkan isi dari meteri yang dilihat dari TV tersebut.

23. Teknik mengajar dimana materi pelajaran disajikan dengan menggunakan program siaran Radio, siswa menerima dengan jalan mendengarkan Radio. Contoh : Dalam hal ini guru dalam memberikan pengajaran kepada siswa, siswa dianjurkan mendengarkan materi pelajaran dalam kaset atau tape, kemudian disuruh untuk menyimpulkan isi dari meteri yang didengarkan dalam radio tersebut.

24. Teknik mengajar dimana siswa baik secara individual maupun dalam bentuk kelompok menyajikan hasil penelitian atau kajian terhadap suatu masalah. Contoh : Di dalam kelas guru menyuruh siswa baik secara individual maupun kelompok, untuk melakukan penelitian atau pengamatan tentang arus lalulintas di jalan raya, kemudian siswa disuruh melaporkan tetang apa yang diteliti dan diamati dan disajikan di dalam kelas untuk dipertanggungjawabkan kepada siswa/kelompok lain.

25. Kegiatan belajar dimana siswa ditugasi untuk memerankan atau menirukan perilaku tokoh-tokoh dari suatu situasi atau kejadian yang nyata. Contoh : Siswa ditugasi untuk memerankan berbagai akting seseorang tokoh pada waktu orasi atau membaca laporan pertanggungjawaban dari masing-masing tugas tokoh tersebut. 
26. Kegiatan belajar dimana siswa baik secara individual maupun kelompok diberi tugas menyelesaikan kegiatan yang hasilnya dapat diamati. Contoh : siswa dianjurkan untuk membuat sebuah patung Pahlawan Revolusi dari kayu atau tanah liat.

27. Kegiatan pembelajaran berupa menyajikan kepada teman sekelas atau kelompok mengenai keterampilan yang telah dikuasai dari hasil studi individu atau kelompok. Contoh : Siswa ditugasi oleh guru untuk menampilkan berbagai atraksi dan kemampuan yang dimiliki dari setiap masing-masing individu atau kelompok, yang disajikan di depan kelompok atau individu yang lain, misalnya dalam menirukan gaya berperang pahlawan dalam melawan penjajah.

28. Metode mengajar dimana siswa ditugasi mengumpulkan hasil penulisan, hasil pengamatan, hasil kunjungan lapangan, pengumpulan benda-benda yang relevan dengan tujuan pembelajaran dsb. Contoh : Di dalam kelas guru menyuruh siswa untuk menemukan suatu masalah, lalu siswa dibagi beberapa kelompok dan di dalam masing-masing kelompok tersebut mendapat bagian-bagian masalah yang ditemukan tersebut, lalu setiap kelompok membahas bagian masalah, lalu siswa bertukar pendapat antara kelompok yang satu dengan yang lainnya.

29. Metode mengajar dimana siswa terjun langsung ke lapangan kerja, mempraktekkan teori yang diperoleh dibangku sekolah. Contoh : Dengan metode ini siswa nantinya diharapkan akan menjadi pendidik melalui program magang ini, dan siswa disuruh melakukan penelitian dan praktek ke berbagai instansi untuk melatih ketrampilan dan kecakapan dalam pribadi peserta didik

30. Teknik mengajar dimana siswa dan guru saling berinteraksi dan berkomunikasi mengenai berbagai materi yang telah diajarkan. Contoh : di kelas guru menerangkan sebuah materi pelajaran, kemudian siswa tersebut disuruh untuk bertanya tentang materi 
yang belum dimengerti dan selanjutnya guru menjawab sebisa mungkin dari pertanyaan siswa tersebut.

31. Suatu teknik dimana siswa diterangkan dan diceritakan melalui berbagai cerita-cerita. Contoh : Guru di kelas menerangkan tentang sejarah Jenderal Sudirman dalam bergerilya di medan perang, kemudian siswa disuruh untuk menentukan dan menganalisis, apakah taktik tersebut cocok untuk diterapakn.

\section{PENGORGANISASIAN PESERTA DIDIK/MAHASISWA}

Dalam dunia pendidikan, peran pengorganisasian mahasiswa dalam halnya untuk mencapai kemaksimalan dalam pembelajaran juga diperluakan. Dalam hal ini management dari seorang guru dan kebijakannya dalam mengambil keputusan setelah melihat keadaan anak didiknya sangat diperlukan. Dengan dukungan penjiwaan serta niatan yang baik dari seorang guru, tentu dalam halmanagement di dalam kelas untuk menentukan cara pembelajaran mana yang paling tepat untuk siswa yang dihadapinya bukanlah menjadi suatu hal yang sulit.

Definisi organisasi yang dikemukakan oleh Oteng Sutisna (dalam Suhardan, dkk, 2009) yaitu mekanisme yang mempersatukan kegiatan-kegiatan yang untuk menyelesaikan pemkerjaan-pekerjaan. Definisi ini menekankan pada mekanisme kerja dalam organisasi untuk mencapai tujuan organisasi. Atau dengan kata lain organisasi adalah suatu system interaksi antarorang yang ditujukan untuk mencapai tujuan organisasi dimana system tersebut memberikan arahan perilaku bagi anggota organisasi. Definisi ini menekankan pada keharusannya sebuah organisasi didasarkan pada interaksi social diantara anggotanya dan anggota dengan lingkungannya supaya tujuan organisasi dapat dicapai secara efektif dan efisien.

Pengertian Peserta Didik menurut ketentuan umum UU No. 20 Tahun 2003 tentang Sistem Pendidikan Nasional adalah anggota masyarakat yang berusaha mengembangkan potensi diri melalui proses pembelajaran yang tersedia pada jalur, jenjang, dan jenis pendidikan tertentu. Dari pengertian beberapa ahli, bisa dikatakan 
bahwa peserta didik adalah orang/individu yang mendapat pelayanan pendidikan sesuai dengan bakat, minat, dan kemampuan agar tumbuh dan berkembang dengan baik serta mempunyai kepuasan dalam menerima pelajaran yang diberikan oleh pendidiknya.

Sehingga organisasi peserta didik adalah suatu system interaksi antara guru dengan murid yang ditujukan mencapai tujuan pembelajaran yaitu mengembangkan bakat, minat, dan kemampuan agar tumbuh dan berkembang dengan baik dimana system tersebut memberikan arahan perilaku dalam proses pembelajaran di kelas.

Dapat diibaratkan sebagai potongan puzzle, pengorganisasian dalam kelas juga memerlukan suatu kecocokan dengan keadaan dalam kelas. Yang mana dalam hal ini perlu diperhatikan situasi serta kondisi ruangan maupun siswa yang ada di dalamnya. Jika keserasian dalam kelas cocok dengan cara pengorganisasian yang diterapkan, tentunya dapat mengurangi kejenuhan siswa dalam belajar dan kemudian yang akan berdampak pada hasil belajarnya. Dalam pengorganisasian siswa terdapat beberapa metode yang dapat diterapkan guru yaitu pembeajaran secara individual, kelompok, dan klasikal.

\section{PENDEKATAN QUANTUM TEACHING}

Quantum Teaching berasal dari dua kata yaitu "Quantum” yang berarti interaksi yang mengubah energi menjadi cahaya dan "Teaching" yang berarti mengajar. Dengan demikian makaQuantum Teaching adalah orkestrasi bermacam-macam interaksi yang ada didalam dan disekitar momen belajar. Interaksi-interaksi ini mencakup unsur-unsur belajar yang efektif yang dapat mempengaruhi kesuksesan siswa. Abuddin Nata, dengan mengutip pendapatnya De Porter mengatakan bahwa Quantum Teaching adalah badan ilmu pengetahuan dan metodologi yang digunakan dalam rancangan, penyajian dan fasilitasi Super Camp. Diciptakan berdasarkan teoriteori pendidikan seperti Accelerated Learning (Lozanov), Multiple Intellegence Gardner), Neuro-Linguistic Programing (Ginder \& Bandler), Eksperiental Learning (Hahn), Socratic Incuiry, 
Cooperative Learning (Jhonson \& Jhonson), dan Element of Effective Intruction (Hunter).

Quantum Teaching merangkaikan yang paling baik dari yang terbaik menjadi paket multisensori, multikecerdasan, dan kompatibel dengan otak, yang pada akhirnya akan melejitkan kemampuan guru untuk mengilhami, dan kemampuan murid untuk berprestasi. Sebagai sebuah pendekatan belajar yang segar, mengalir, praktis dan mudah diterapkan.

Model pembelajaran Quantum Teaching mulai dikembangkan di Amerika sekitar tahun 1999, yang dipelopori oleh Bobbi DePorter dan Mark Reardon (Suyitno, 2004:34). Quantum Teaching dimulai di Super Camp, sebuah program percepatan Quantum Learning yang ditawarkan oleh Learning Forum. Dalam program menginap selama dua belas hari ini siswa memperoleh kiat-kiat yang membantu mereka dalam mencatat, menghafal, membaca, menulis, berkreatifitas, berkomunikasi serta membina hubungan. Adapun hasil-hasil yang dicapai dalam Super Camp: 68\% meningkatkan motivasi, 73\% meningkatkan nilai, $81 \%$ meningkatkan rasa percaya diri, $84 \%$ meningkatkan harga diri, dan $98 \%$ melanjutkan penggunaan keterampilan, (DePorter, 2004:4).

Porter (2000:3) menyatakan bahwa, "Quantum Teaching menunjukan kepada anda menjadi guru yang baik. Quantum Teaching cara-cara yang baru yang memudahkan proses belajar lewat pemanduan unsur seni dan pencapaian-pencapaian yang terarah, apapun mata pelajaran yang anda ajarkan. Dan dengan menggunakan metode Quantum Teaching anda akan dapat menggabungkan keistimewaan-keistimewaan belajar menuju bentuk perencanaan pelajaran yang akan melejitkan prestasi siswa".

Quantum Teaching merupakan suatu proses pembelajaran dengan menyediakan latar belakang dan strategi untuk meningkatkan proses belajar mengajar dan membuat proses tersebut menjadi lebih menyenangkan. Cara ini memberikan sebuah gaya mengajar yang memberdayakan siswa untuk berprestasi lebih dari yang dianggap 
mungkin. Juga membantu guru memperluas keterampilan siswa dan motivasi siswa, sehingga guru akan memperoleh kepuasan yang lebih besar dari pekerjaannya.

Dalam Quantum Teaching terdapat tiga hal yang harus dipahami yaitu, Quantum, Pemercepatan belajar, dan fasilitasi. Quantum artinya adalah interaksi yang mengubah energi menjadi cahaya. Sehingga Quantum Teaching adalah upaya guru mengorkestrasikan berbagai interaksi yang berada di dalam dan di sekitar momen belajar, sehingga kemampuan dan bakat alamiah siswa menjadi cahaya. Interaksi-interaksi mencakup unsur-unsur untuk belajar efektif yang mempengaruhi kesuksesan siswa, sekaligus mengubah kemampuan dan bakat alamiah siswa menjadi cahaya yang bermanfaat bagi mereka sendiri dan orang lain, (DePorter, 2004:5).

Pemercepatan belajar berarti menyingkirkan hambatan yang menghalangi proses belajar alamiah dengan sengaja menggunakan musik, mewarnai lingkungan sekeliling, menyusun bahan pengajaran yang sesuai, dan keterlibatan aktif, (DePorter, 2004:5). Fasilitasi, artinya memudahkan segala hal. Fasilitasi dalam konteks ini merujuk pada implementasi strategi menyingkirkan hambatan belajar, mengembalikan proses belajar ke keadaan yang mudah dan alami. Fasilitasi ini juga termasuk penyediaan alat-alat bantu yang memudahkan siswa belajar, (DePorter, 2004:6).

Dengan Quantum teaching guru dapat mengajar dengan memfungsikan kedua belahan otak kiri dan otak kanan pada fungsinya masing-masing. Penelitian di Universitas California mengungkapkan bahwa masing-masing otak tersebut mengendalikan aktivitas intelektual yang berbeda. Otak kiri menangani angka, susunan, logika, organisasi, dan hal lain yang memerlukan pemikiran rasional, beralasan dengan pertimbangan yang deduktif dan analitis. Bagian otak ini yang digunakan berpikir mengenai hal-hal yang bersifat matematis dan ilmiah. Kita dapat memfokuskan diri pada garis dan rumus, dengan mengabaikan kepelikan tentang warna dan irama. 
Otak kanan mengurusi masalah pemikiran yang abstrak dengan penuh imajinasi. Misalnya warna, ritme, musik, dan proses pemikiran lain yang memerlukan kreativitas, orisinalitas, daya cipta dan bakat artistik. Pemikiran otak kanan lebih santai, kurang terikat oleh parameter ilmiah dan matematis. Kita dapat melibatkan diri dengan segala rupa dan bentuk, warna-warni dan kelembutan, dan mengabaikan segala ukuran dan dimensi yang mengikat.

\section{E. PENDEKATAN MULTIPLE INTEGENCES}

Pendekatan pembelajaran multiple intelligence yang dalam bahasa asingnya di singkat dengan MITA (Multiple Intelligence Teaching Approach), meliputi lima fase yaitu: Question Possibilities, Target Improvement, Expect Quality, Move Resources ,dan Reflect for Growth Possibilities. Pada tahap Question Possibilities, siswa diberikan pertanyaan berdasarkan topik pelajaran sesuai dengan minat dan kemampuan siswa misalkan mengaitkan dengan kehidupan sehari-hari mereka sehingga mereka dapat lebih tertarik dan mengetahui apa yang mereka pelajari. Pada tahap ini dapat dimunculkan kecerdasan naturalis siswa. Pada tahap Target Improvement, siswa diberikan target yang harus dikuasai siswa dalam pembelajaran seperti standar kompetensi, kompetensi dasar dan indikator yang harus dicapai siswa.

Pada tahap Expect Quality, siswa diberikan bentuk evaluasi dan tahapan-tahapan dalam pembelajaran untuk memotivasi siswa dalam pembelajaran. Pada tahap Move Resources, siswa memecahkan permasalahan yang telah diberikan pada fase pertama misalkan melakukan eksperimen kemudian menganalisisnya. Pada tahap ini dapat dimunculkan kecerdasan logika matematika dari menganalisis hasil yang didapat dalam eksperimen, kecerdasan linguistik yaitu berupa presentasi dan mengemukakan pendapat, kecerdasan visual yakni membuat grafik dan kecermatan dalam mengamati percobaan yang telah dilakukan, kecerdasan kinestetik siswa yakni dengan 
memainkan peran (role play) dan kecerdasan interpersonal yaitu dalam berkelompok dan bekerja sama.

Pada tahap Reflect for Growth Possibilities, siswa merefleksikan diri dengan mengerjakan pertanyaan secara individu sehingga pendidik dapat mengetahui pemahaman masing-masing siswa tentang konsep yang diajarkan sehingga pada tahap ini dapat dimunculkan kecerdasan intrapersonal siswa.

Pada MITA, diciptakan tempat untuk siswa menggambarkan pengetahuan awal dan untuk memecahkan permasalahan dalam kehidupan sehari-hari. Melalui pertanyaan yang relevan akan menyebabkan siswa berpikir, kemudian mempersiapkan dan menggunakan pikiran mereka pada suatu pembelajaran. Tahap untuk hasil pembelajaran yang spesifik menunjukkan siswa menghasilkan pengetahuan yang kita harapkan dengan tepat. Rubrik mengidentifikasi dan memastikan siswa mencapai hasil yang lebih baik. Tugas Penilaian menciptakan pertukaran interaktif di mana semua siswa menggambar pengetahuan mereka sendiri dari sesuatu yang unik dan akhirnya mereka merefleksi pengetahuan mereka untuk mempertimbangkan strategi dan gagasan baru yang mengilhami pengertian yang mendalam untuk memecahkan pertanyaan sehari-hari (Weber, 2001).।

\section{F. PENDEKATAN E-LEARNING}

Pendekatan e-learning atau electronic learning merupakan salah satu pendekatan pembelajaran dengan menggunakan jasa bantuan perangkat elektronik, khususnya perangkat komputer. Karena itu maka e-learning sering disebut juga 'online course'. Soekartawi (dalam Dewi Salma P dan Eveline Siregar, 2004) mengemukakan bahwa dalam berbagai literatur, e-learningdidefinisikan sebagai $a$ generic term for all technologically supported learning using an array of teaching and learning tools as phone bridging, audio and videotapes, teleconferencing, satellite tranmissions, and the more recognized web-based training or computer aided instruction also commonly referred to as online course (Soekartawi, Haryono dan 
Libero, 2002). Merujuk literatur ini maka e-learning dapat diartikan sebagai pembelajaran yang pelaksanaannya di dukung oleh jasa teknologi seperti telpon, audio, videotape, transmisi satelit, atau komputer.

Menurut Soekartawi (2004), dalam perkembangannya komputer dipakai sebagai alat bantu pembelajaran, karena itu dikenal dengan istilah computer based learning (CBL) atau Computer assisted learning(CAL). Ketika pertama-tama komputer mulai diperkenalkan khususnya di pembelajaran, maka ia menjadi populer di kalangan anak didik. Bisa dimengerti karena berbagai variasi teknik mengajar bisa dikelompokkan menjadi dua, yaitu (1)Technology-based learning, dan (2) Technology-based Weblearning.

Soekartawi (2004) mencatat bahwa terdapat sejumlah manfaat dan kelebihan pendekatan e-learning ini yang dapat dirasakan oleh para pembelajar, namun sejumlah kelemahan juga ditemukan antara lain (1) kurangnya interaksi antara guru dengan siswa atau bahkan antar siswa itu sendiri, (2) adanya kecenderungan mengutamakan aspek bisnis dan mengabaikan aspek sosial, (3) proses pembelajaran lebih cenderung ke arah pelatihan, (4) siswa yang tidak mempunyai motivasi yang tinggi cenderung gagal, (5) tidak semua tempat dan siswa memiliki internet.

\section{G. PENDEKATAN BELAJAR AKTIF (ACTIVELEARNING)}

Model pembelajaran aktif (active earning model) merupakan model pembelajaran yang mengutamakan aktivitas belajar siswa melalui diskusi kelompok, diskusi kelas, eksperimen dan demonstrasi dalam menemukan konsep baru. Hal ini mengakibatkan aktivitas siswa lebih dominan selama proses pembelajaran. Hal ini sesuai dengan kesimpulan dari Yerigan (dalam Hartono, 2010) dalam penelitiannya yang berjudul Getting Active In The Classroom. Ia menyimpulkan bahwa pembelajaran aktif dapat meningkatkan interaksi antar siswa dan taraf bepikir tingkat tinggi siswa. 
Menurut Wibowo (2007) pembelajaran aktif secara pedagogis adalah proses pembelajaran yang tidak hanya mendengarkan dan mencatat. Pembelajaran aktif adalah proses pembelajaran yang melibatkan siswa dalam melakukan sesuatu dan berpikir tentang apa yang akan mereka lakukan. Pembelajaran aktif mendasarkan pada asumsi bahwa pembelajaran pada dasarnya adalah pencarian secara aktif pengetahuan dan setiap orang belajar dengan cara yang berbeda. Pembelajaran aktif pada dasarnya memberikan kesempatan kepada siswa untuk melakukan aktivitas belajar berupa hubungan interaktif dengan materi pelajaran, sehingga siswa terdorong menyimpulkan dan merefleksikan pemahaman (Ramdani, 2010). Proses belajar aktif mengarahkan siswa dalam kegiatan membaca, menulis, mendiskusikan, atau terlibat dalam memecahkan masalah. Siswa dilibatkan secara aktif dalam kegiatan berpikir analisis, sintesis, dan evaluasi.

Kegiatan belajar aktif diartikan sebagai instruktur kegiatan yang melibatkan siswa dalam melakukan sesuatu dan berpikir tentang apa yang mereka kerjakan. Siswa dilibatkan dalam proses pengumpulan informasi dan mengkonstruksinya, sehingga pembelajaran menjadi menyenangkan. Proses belajar dengan model pembelajaran aktif (active learning) adalah sebuah proses di mana siswa mengambil tanggung jawab diri dan diberikan kesempatan untuk membuat keputusan tentang berbagai kegiatan belajar yang dilakukan. Siswa dipersiapkan untuk menghadapi masalah nyata di lingkungan mereka dan mampu memecahkan masalah sesuai solusi yang didapatkan dari pengalaman belajar (Kuwadekar \& Neville, 2011).

Pembelajaran aktif memberikan kesempatan pada siswa untuk berpatisipasi aktif dalam pembelajaran. Guru hanya berperan sebagai fasilitator yang memastikan bahwa proses pembelajaran sesuai dengan rencana yang diharapkan. Pada bagian akhir guru melakukan tanya jawab untuk memastikan materi yang diterima benar dan tidak menyimpang dari konsep yang seharusnya (Kuwadekar \& Neville, 
2011). Pembelajaran aktif (active learning) dimaksudkan untuk mengoptimalkan penggunaan semua potensi yang dimiliki oleh anak didik, sehingga anak didik dapat mencapai hasil belajar yang memuaskan sesuai karakteristik pribadi yang mereka miliki. Pembelajaran aktif juga dimaksudkan untuk menjaga perhatian siswa agar tetap tertuju pada proses pembelajaran (Morgado, 2010). Pembelajaran aktif melihat proses belajar adalah produk dari berpikir dan berpikir adalah produk dari sebuah proses belajar (Narli, 2011).

\section{HP PENDEKATAN KONSTEKTUAL}

Contextual Teaching and Learning (CTL) adalah suatu pendekatan pembelajaran yang menekankan kepada proses keterlibatan siswa secara penuh untuk dapat menemukan materi yang dipelajari dan menghubungkannya dengan situasi kehidupan nyata sehingga mendorong siswa untuk dapat menerapkannya dalam kehidupan mereka.Dari konsep tersebut ada tiga hal yang harus dipahami.Pertama, CTL menekankan kepada proses keterlibatan siswa untuk menemukan materi, artinya proses belajar diorientasikan pada proses pengalaman secara langsung dan siswa diharapkan dapat mencari dan menemukan sendiri materi pelajaran. Kedua, CTL mendorong agar siswa dapat menemukan hubungan antara materi yang dipelajari dengan situasi kehidupan nyata. Hal ini sangat penting bagi siswa karena materi akan menjadi bermakna dan tertanam erat dalam memori siswa, sehingga tidak akan mudah dilupakan. Ketiga, CTL mendorong siswa untuk dapat menerapkannya dalam kehidupan, artinya CTL bukan hanya mengharapkan siswa dapat memahami materi yang dipelajarinya, akan tetapi bagaimana materi pelajaran itu dapat mewarnai perilakunya dalam kehidupan sehari-hari (Sanjaya, 2008).

Kontekstualitas merupakan fenomena yang bersifat alamiah, tumbuh dan terus berkembang, serta beragam karena berkaitan dengan fenomena kehidupan sosial masyarakat. Dalam kaitannya dengan ini, maka pembelajaran pada dasarnya merupakan aktivitas 
mengaktifkan, menyentuhkan, mempertautkan; menumbuhkan, mengembangkan, dan membentuk pemahaman melalui penciptaan kegiatan, pembangkitan penghayatan, internalisasi, proses penemuan jawaban pertanyaan, dan rekonstruksi pemahaman melalui refleksi yang berlangsung secara dinamis.

Sementara itu, belajar pada dasarnya merupakan proses menyadari sesuatu, memahami permasalahan, proses adaptasi dan organisasi, proses asimilasi dan akomodasi, proses menghayati dan memikirkan, proses mengalami dan merefleksikan,dan proses membuat komposisi dan membuka ulang secara terbuka dan dinamis. Itulah sebabnya landasan pembelajaran kontekstual adalah konsep konstruktivisme (Aryans, 2007).

Program pembelajaran kontekstual memiliki prinsip dasar sebagai berikut:

1. Belajar berbasis masalah (Problem Based Learning). Belajar bukanlah sekedar drill informasi tetapi bagaimana menggunakan informasi dan berpikir kritis dalam memecahkan masalah yang ada di dunia nyata.

2. Pengajaran autentik (Authentic Instruction). Pendekatan pengajaran yang memperkenankan siswa untuk mempelajari konteks bermakna, sesuai dengan kehidupan nyata.

3. Belajar berbasis inquiri (Inquiry-Based Learning). Belajar bukanlah kegiatan mengkonsumsi melainkan kegiatan memproduksi dengan mengetahui apa yang menjadi kebutuhan, keinginan dan mencari tahu sendiri jawabannya.

4. Belajar berbasis proyek / tugas terstruktur (Proyect-Based Learning). Belajar bukan sekedar menyerap hal kecil sedikit demi sedikit dalam waktu yang panjang, tetapi secara komprehensif/terpadu untuk mendapatkan banyak hal.

5. Belajar berbasis kerja (Work-Based Learning). Belajar harus didasarkan pada pengalaman dan bukan kata-kata semata. Belajar adalah bekerja dan ketika orang bekerja, maka ia belajar banyak hal. 
6. Belajar jasa layanan (Service Learning). Belajar dengan menumbuhkan rasa percaya diri, merasa dibutuhkan, bekerja sama/menolong orang lain, dan akrab pada kegiatan di luar maupun di dalam kelas.

7. Belajar kooperatif (Cooperatif Learning). Belajar melalui interaksi dengan teman-teman, belajar bersama akan menghasilkan prestasi lebih baik daripada setiap individu belajar sendiri-sendiri.

\section{PENDEKATAN BELAJAR BERBASIS SEKOLAH}

Pendekatan pembelajaran berdasarkan sekolah adalah pendekatan pembelajaran yang menggunakan masalah sebagai langkah awal untuk mendapatkan pengetahuan baru. Seperti yang diungkapkan oleh Suyatno (2009 : 58) bahwa :

"Pendekatan pembelajaran berdasarkan sekolah adalah proses pembelajaran yang titik awal pembelajaran dimulai berdasarkan masalah dalam kehidupan nyata siswa dirangsang untuk mempelajari masalah berdasarkan pengetahuan dan pengalaman telah mereka miliki sebelumnya (prior knowledge) untuk membentuk pengetahuan dan pengalaman baru".

Jadi pembelajaran ini menggunakan masalah sebagai langkah awal dalam mengumpulkan dan mengintregasikan pengetahuan baru. Hal serupa juga dikemukakan oleh Nurhadi (2004 :109) :" Pendekatan pembelajaran berdasarkan sekolah adalah suatu pembelajaran yang menggunakan masalah dunia nyata sebagai suatu konteks bagi siswa untuk belajar tentang cara berfikir kritis dan keterampilan pemecahan masah serta untuk memperoleh pengetahuan dan konsep yang esensial dari materi pelajaran". Dalam hal ini pengajaran berbasis sekolah digunakan untuk merangsang berpikir tingkat tinggi dalam situasi berorientasi masalah.

Dari pendapat-pendapat para ahli diambil kesimpulan pendekatan pembelajaran berbasis sekolah merupakan suatu pendekatan pembelajaran yang menggunakan masalah sebagai titik tolak (starting point) pembelajaran. Masalah-masalah yang dapat 
dijadikan sebagai sarana belajar adalah masalah yang memenuhi konteks dunia nyata (real world), yang akrab dengan kehidupan sehari-hari para siswa. Melalui masalah-masalah kontekstual ini para siswa menemukan kembali pengetahuan konsep-konsep dan ide-ide yang esensial dari materi pelajaran dan membangunnya ke dalam stuktur kognitif.

\section{J. PENDEKATAN BELAJAR KOOPERATIF}

Menurut Zaini model pembelajaran adalah "pedoman berupa program atau petunjuk strategi mengajar yang dirancang untuk mencapai suatu tujuan pembelajaran. Pedoman itu memuat tanggung jawab guru dalam merencanakan, melaksanakan, dan mengevaluasi kegiatan pembelajaran. Salah satu tujuan dari penggunaan model pembelajaran adalah untuk meningkatkan kemampuan siswa selama belajar."

Dengan pemilihan metode, strategi, pendekatan, serta teknik pembelajaran, diharapkan adanya perubahan dari mengingat (memorizing) atau menghafal (rote learning) ke arah berpikir (thinking) dan pemahaman (understanding), dari model ceramah ke pendekatan discovery learning atau inquiry learning, dari belajar individual ke kooperatif, serta dari subject centered ke learner centered atau terkonstruksinya pengetahuan siswa.

Model pembelajaran kooperatif merupakan suatu model pembelajaran yang mengutamakan adanya kelompok-kelompok. Setiap siswa yang ada dalam kelompok mempunyai tingkat kemampuan yang berbeda-beda (tinggi, sedang, rendah). Model pembelajaran kooperatif mengutamakan kerja sama dalam menyelesaikan permasalahan untuk menerapkan pengetahuan dan keterampilan dalam rangka mencapai tujuan pembelajaran .

Holubec dalam Nurhadi mengemukakan belajar kooperatif "merupakan pendekatan pembelajaran melalui kelompok kecil siswa untuk bekerja sama dalam memaksimalkan kondisi belajar dalam mencapai tujuan belajar. Pembelajaran kooperatif adalah 
pembelajaran yang secara sadar dan sistematis mengembangkan interaksi yang saling asah, silih asih, dan silih asuh."

Sementara itu, Bruner dalam Siberman menjelaskan bahwa belajar secara bersama merupakan kebutuhan manusia yang mendasar untuk merespons manusia lain dalam mencapai suatu tujuan.

Menurut Nur (2000), semua model pembelajaran ditandai dengan adanya struktur tugas, struktur tujuan, dan struktur penghargaan. Struktur tugas, struktur tujuan, dan struktur penghargaan pada model pembelajaran kooperatif berbeda dengan struktur tugas, struktur tujuan, dan struktur penghargaan pada model pembelajaran yang lain. Dalam proses pembelajaran dengan model pembelajaran kooperatif, siswa didorong untuk bekerja sama pada suatu tugas bersama dan mereka harus mengkoordinasikan usahanya untuk menyelesaikan tugas yang diberikan guru. Tujuan model pembelajaran kooperatif adalah hasil belajar akademik siswa meningkat dan siswa dapat menerima berbagai keragaman dari temannya, serta berkembangnya keterampilan sosial.

Pembelajaran kooperatif adalah khas di antara model-model pembelajaran karena menggunakan suatu struktur tugas dan penghargaan yang berbeda untuk meningkatkan pembelajaran siswa. Struktur tugas memaksa siswa untuk bekerja sama dalam kelompok kecil. Sistem penghargaan mengakui usaha bersama, sama baiknya seperti usaha individual.

Model pembelajaran kooperatif berkembang dari kebiasaan pendidikan yang menekankan pada pemikiran demokratis dan latihan atau praktek, pembelajaran aktif, lingkungan pembelajaran yang kooperatif dan menghormati adanya perbedaan budaya masyarakat yang bermacam-macam.

Model pembelajaran kooperatif bertumpu pada kerja kelompok kecil, berlawanan dengan pembelajaran klasikal (satu kelas penuh), dan terdiri 6 (enam) tahapan pokok: menentukan tujuan dan pengaturan, memberi informasi kepada siswa melalui presentasi atau teks, menyusun siswa dalam kelompok belajar, menentukan 
kelompok dan membantu kelompok belajar, menguji atau melakukan tes untuk mengetahui keberhasilan dari tugas-tugas kelompok, penghargaan baik terhadap prestasi individu maupun kelompok. Diperlukan lingkungan pembelajaran yang kooperatif dari pada kompetitif dalam hal tugas-tugas dan penghargaan. 


\section{BAB VIII \\ MODEL DAN METODE PEMBELAJARAN}

\section{A. PENGERTIAN MODEL}

Model adalah representasi dari suatu objek, benda, atau ide-ide dalam bentuk yang disederhanakan dari kondisi atau fenomena alam. Model berisi informasi- informasi tentang suatu fenomena yang dibuat dengan tujuan untuk mempelajari fenomena sistem yang sebenarnya. Model dapat merupakan tiruan dari suatu benda, sistem atau kejadian yang sesungguhnya yang hanya berisi informasiinformasi yang dianggap penting untuk ditelaah. (Mahmud Achmad, 2008: 1).

Model pembelajaran adalah seluruh rangkaian penyajian materi ajar yang meliputi segala aspek sebelum sedang dan sesudah pembelajaran yang dilakukan guru serta segala fasilitas yang terkait yang digunakan secara langsung atau tidak langsung dalam proses belajar mengajar.

Pengertian model pembelajaran adalah kerangka konseptual dan operasional pembelajaran yang memiliki nama, ciri, urutan logis, pengaturan, dan budaya. Hal ini sesuai dengan Permendikbud No.103 Tahun 2014 tentang Pembelajaran pada Pendidikan Dasar dan Pendidikan Menengah, Pasal 2.

Secara umumnya, model pembelajaran adalah cara atau teknik penyajian sistematis yang digunakan oleh guru dalam mengorganisasikan pengalaman proses pembelajaran agar tercapai tujuan dari sebuah pembelajaran. Definisi singkat lainnya yaitu suatu pendekatan yang digunakan dalam kegiatan pembelajaran.

Model pembelajaran bisa juga diartikan sebagai seluruh rangkaian penyajian materi yang meliputi segala aspek sebelum, sedang dan sesudah pembelajaran yang dilakukan guru serta segala fasilitas yang terkait yang digunakan secara langsung atau tidak langsung dalam proses belajar mengajar. Model pembelajan sendiri 
memiliki makna yang lebih luas dari pada strategi, metode atau sekedar prosedur pembelajaran.

Model pembelajaran adalah rencana atau pola yang digunakan dalam menyusun kurikulum, mengatur materi pengajaran dan memberi petunjuk pada pengajar di kelas dalam setting pengajaran atau setting lainnya. Tiap model mengajar yang dipilih haruslah mengungkapkan berbagai realitas yang sesuai dengan situasi kelas dan macam pandangan hidup, yang dihasilkan dari kerjasama guru dan murid.

\section{B. MODEL PEMBELAJARAN}

\section{1) Fungsi Model Pembelajaran}

Fungsi Model Pembelajaran adalah sebagai pedoman bagi pengajar dan para guru dalam melaksanakan pembelajaran. Hal ini menunjukkan bahwa setiap model yang akan digunakan dalam pembelajaran menentukan perangkat yang dipakai dalam pembelajaran tersebut. Selain itu, model pembelajaran juga berfungsi sebagai pedoman bagi para perancang pembelajaran dan para pengajar dalam merencanakan dan melaksanakan aktivitas belajar mengajar sehingga tujuan pembelajaran dapat tercapai.

2) Ciri-ciri Model Pembelajaran

Istilah model Pembelajaran mempunyai makna yang lebih luas daripada strategi, metode, atau prosedur. Model pembelajaran mempunyai empat ciri khusus yang tidak dimiliki oleh strategi, metode, atau prosedur. Ciri-ciri tersebut antara lain:

a) Rasional teoritik yang logis, disusun oleh para pencipta atau pengembangnya;

b) Landasan pemikiran tentang apa dan bagaimana siswa belajar (tujuan pembelajaran yang akan dicapai);

c) Tingkah laku mengajar yang diperlukan agar model tersebut dapat dilaksanakan dengan berhasil;

d) Lingkungan belajar yang diperlukan agar tujuan pembelajaran itu dapat tercapai (Kadir dan Nur, 2009:0) 
3) Macam-macam Model Pembelajaran

a) Examples Non Examples

Langkah-langkah:

- Guru mempersiapkan gambar-gambar sesuai dengan tujuan pembelajaran.

- Guru menempelkan gambar di papan atau ditayangkan melalui OHP.

- Guru memberi petunjuk dan memberi kesempatan pada siswa untuk memperhati $\neg$ kan/menganalisa gambar.

- Melalui diskusi kelompok 2-3 orang siswa, hasil diskusi dari analisa gambar tersebut dicatat pada kertas.

- Tiap kelompok diberi kesempatan membacakan hasil diskusinya.

- Mulai dari komentar/hasil diskusi siswa, guru mulai menjelaskan materi sesuai tujuan yang ingin dicapai.

- Kesimpulan

\section{b) Numbered Heads Together}

Langkah-langkah:

- Siswa dibagi dalam kelompok, setiap siswa dalam setiap kelompok mendapat nomor.

- Guru memberikan tugas dan masing-masing kelompok mengerjakannya.

- Kelompok mendiskusikan jawaban yang benar dan memastikan tiap anggota kelompok dapat mengerjakannya/mengetahui jawabannya.

- Guru memanggil salah satu nomor siswa dengan nomor yang dipanggil melaporkanhasil kerjasama mereka.

- Tanggapan dari teman yang lain, kemudian guru menunjuk nomor yang lain.

- Kesimpulan.

\section{c) Cooperative Script}

Langkah-langkah: 
- Guru membagi siswa untuk berpasangan.

- Guru membagikan wacana/materi tiap siswa untuk dibaca dan membuat ringkasan.

- Guru dan siswa menetapkan siapa yang pertama berperan sebagai pembicara dan siapa yang berperan sebagai pendengar.

- Pembicara membacakan ringkasannya selengkap mungkin, dengan memasukkan ide-ide pokok dalam ringkasannya. Sementara pendengar:

- Menyimak/mengoreksi/menunjukkan ide-ide pokok yang kurang lengkap.

- Membantu mengingat/menghafal ide-ide pokok dengan menghubungkan materi sebelumnya atau dengan materi lainnya

- Bertukar peran, semula sebagai pembicara ditukar menjadi pendengar dan sebaliknya. Serta lakukan seperti diatas.

- Kesimpulan Siswa bersama-sama dengan Guru.

- Penutup.

\section{d) Kepala Bernomor Struktur}

Langkah-langkah:

- Siswa dibagi dalam kelompok, setiap siswa dalam setiap kelompok mendapat nomor.

- Penugasan diberikan kepada setiap siswa berdasarkan nomor terhadap tugas yang berangkai. Misalnya: siswa nomor satu bertugas mencatat soal. Siswa nomor dua mengerjakan soal dan siswa nomor tiga melaporkan hasil pekerjaan dan seterusnya.

- Jika perlu, guru bisa menyuruh kerja sama antar kelompok. Siswa disuruh keluar dari kelompoknya dan bergabung bersama beberapa siswa bernomor sama dari kelompok lain. Dalam kesempatan ini siswa dengan tugas yang sama bisa saling membantu atau mencocokkan hasil kerja sama mereka. 
- Laporkan hasil dan tanggapan dari kelompok yang lain.

- Kesimpulan.

\section{e) Student Teams Achievement - Divisions (STAD)}

Langkah-langkah:

- Membentuk kelompok yang anggotanya $=4$ orang secara heterogen (campuran menurut prestasi, jenis kelamin, suku, dll).

- Guru menyajikan pelajaran.

- Guru memberi tugas kepada kelompok untuk dikerjakan oleh anggota-anggota kelompok. Anggotanya yang sudah mengerti dapat menjelaskan pada anggota lainnya sampai semua anggota dalam kelompok itu mengerti.

- Guru memberi kuis/pertanyaan kepada seluruh siswa. Pada saat menjawab kuis tidak boleh saling membantu.

- Memberi evaluasi.

- Kesimpulan

\section{f) Jigsaw}

Langkah-langkah:

- Siswa dikelompokkan ke dalam $=4$ anggota tim.

- Tiap orang dalam tim diberi bagian materi yang berbeda.

- Tiap orang dalam tim diberi bagian materi yang ditugaskan.

- Anggota dari tim yang berbeda yang telah mempelajari bagian/sub bab yang sama bertemu dalam kelompok baru (kelompok ahli) untuk mendiskusikan sub bab mereka.

- Setelah selesai diskusi sebagai tim ahli tiap anggota kembali ke kelompok asal dan bergantian mengajar teman satu tim mereka tentang sub bab yang mereka kuasai dan tiap anggota lainnya mendengarkan dengan sungguh-sungguh.

- Tiap tim ahli mempresentasikan hasil diskusi.

- Guru memberi evaluasi.

- Penutup. 


\section{g) Problem Based Indtroduction (PBI)}

Langkah-Langkah:

- Guru menjelaskan kompetensi yang ingin dicapai dan menyebutkan sarana atau alat pendukung yang dibutuhkan. Memotivasi siswa untuk terlibat dalam aktivitas pemecahan masalah yang dipilih.

- Guru membantu siswa mendefinisikan dan mengorganisasikan tugas belajar yang berhubungan dengan masalah tersebut (menetapkan topik, tugas, jadwal, dll.)

- Guru mendorong siswa untuk mengumpulkan informasi yang sesuai, eksperimen untuk mendapatkan penjelasan dan pemecahan masalah, pengumpulan data, hipotesis, pemecahan masalah.

- Guru membantu siswa dalam merencanakan menyiapkan karya yang sesuai seperti laporan dan membantu mereka berbagi tugas dengan temannya.

- Guru membantu siswa untuk melakukan refleksi atau evaluasi terhadap eksperimen mereka dan proses-proses yang mereka gunakan.

\section{h) Artikulasi}

Langkah-langkah:

- Guru menyampaikan kompetensi yang ingin dicapai.

- Guru menyajikan materi sebagaimana biasa.

- Untuk mengetahui daya serap siswa, bentuklah kelompok berpasangan dua orang.

- Menugaskan salah satu siswa dari pasangan itu menceritakan materi yang baru diterima dari guru dan pasangannya mendengar sambil membuat catatan-catatan kecil, kemudian berganti peran. Begitu juga kelompok lainnya.

- Menugaskan siswa secara bergiliran/diacak menyampaikan hasil wawancaranya dengan teman pasangannya. Sampai sebagian siswa sudah menyampaikan hasil wawancaranya. 
- Guru mengulangi/menjelaskan kembali materi yang sekiranya belum dipahami siswa.

- Kesimpulan/penutup.

\section{i) Mind Mapping}

Langkah-langkah:

- Guru menyampaikan kompetensi yang ingin dicapai.

- Guru mengemukakan konsep/permasalahan yang akan ditanggapi oleh siswa dan sebaiknya permasalahan yang mempunyai alternatif jawaban.

- Membentuk kelompok yang anggotanya 2-3 orang.

- Tiap kelompok menginventarisasi/mencatat alternatif jawaban hasil diskusi.

- Tiap kelompok (atau diacak kelompok tertentu) membaca hasil diskusinya dan guru mencatat di papan dan mengelompokkan sesuai kebutuhan guru.

- Dari data-data di papan siswa diminta membuat kesimpulan atau guru memberi perbandingan sesuai konsep yang disediakan guru.

\section{j) Make a Match}

Langkah-langkah:

- Guru menyiapkan beberapa kartu yang berisi beberapa konsep atau topik yang cocok untuk sesi review, sebaliknya satu bagian kartu soal dan bagian lainnya kartu jawaban.

- Setiap siswa mendapat satu buah kartu.

- Tiap siswa memikirkan jawaban/soal dari kartu yang dipegang.

- Setiap siswa mencari pasangan yang mempunyai kartu yang cocok dengan kartunya (soal jawaban).

- Setiap siswa yang dapat mencocokkan kartunya sebelum batas waktu diberi poin.

- Setelah satu babak kartu dikocok lagi agar tiap siswa mendapat kartu yang berbeda dari sebelumnya 
- Demikian seterusnya.

- Kesimpulan/penutup.

\section{k) Think Pair and Share (Frank Lyman, 1985)}

Langkah-langkah:

- Guru menyampaikan inti materi dan kompetensi yang ingin dicapai

- Siswa diminta untuk berfikir tentang materi/permasalahan yang disampaikan guru.

- Siswa diminta berpasangan dengan teman sebelahnya (kelompok 2 orang) dan mengutarakan hasil pemikiran masing-masing.

- Guru memimpin pleno kecil diskusi, tiap kelompok mengemukakan hasil diskusinya.

- Berawal dari kegiatan tersebut, Guru mengarahkan pembicaraan pada pokok permasalahan dan menambah materi yang belum diungkapkan para siswa.

- Guru memberi kesimpulan.

- Penutup.

\section{l) Debate}

Langkah-langkah:

- Guru membagi dua kelompok peserta debat yang satu pro dan yang lainnya kontra.

- Guru memberikan tugas untuk membaca materi yang akan didebatkan oleh kedua kelompok diatas.

- Setelah selesai membaca materi, Guru menunjuk salah satu anggota kelompok pro untuk berbicara saat itu, kemudian ditanggapi oleh kelompok kontra. Demikian seterusnya sampai sebagian besar siswa bisa mengemukakan pendapatnya.

- Sementara siswa menyampaikan gagasannya, guru menulis inti/ide-ide dari setiap pembicaraan sampai mendapatkan sejumlah ide diharapkan. 
- Guru menambahkan konsep/ide yang belum terungkap.

- Dari data-data yang diungkapkan tersebut, guru mengajak siswa membuat kesimpulan/rangkuman yang mengacu pada topik yang ingin dicapai.

m) Role Playing

Langkah-langkah:

- Guru menyusun/menyiapkan skenario yang akan ditampilkan.

- Menunjuk beberapa siswa untuk mempelajari skenario dalam waktu beberapa hari sebelum KBM.

- Guru membentuk kelompok siswa yang anggotanya 5 orang.

- Memberikan penjelasan tentang kompetensi yang ingin dicapai.

- Memanggil para siswa yang sudah ditunjuk untuk melakonkan skenario yang sudah dipersiapkan.

- Masing-masing siswa berada di kelompoknya sambil mengamati skenario yang sedang diperagakan.

- Setelah selesai ditampilkan, masing-masing siswa diberikan lembar kerja untuk membahas penampilan masing-masing kelompok.

- Masing-masing kelompok menyampaikan hasil kesimpulannya.

- Guru memberikan kesimpulan secara umum.

- Evaluasi.

- Penutup.

n) Group Investigation (Sharan, 1992)

Langkah-langkah:

- Guru membagi kelas dalam beberapa kelompok heterogen.

- Guru menjelaskan maksud pembelajaran dan tugas kelompok. 
- Guru memanggil ketua kelompok dan setiap kelompok mendapat tugas satu materi/tugas yang berbeda dari kelompok lain.

- Masing-masing kelompok membahas materi yang sudah ada secarakooperatif yang bersifat penemuan.

- Setelah selesai diskusi, juru bicara kelompok menyampaikan hasil pembahasan kelompok.

- Guru memberikan penjelasan singkat sekaligus memberi kesimpulan

- Evaluasi

- Penutup.

\section{o) Talking Stick}

Langkah-langkah:

- Guru menyiapkan sebuah tongkat.

- Guru menyampaikan materi pokok yang akan dipelajari, kemudian memberikan kesempatan kepada siswa untuk membaca dan mempelajari materi.

- Setelah selesai membaca materi/buku pelajaran dan mempelajarinya, siswa menutup bukunya.

- Guru mengambil tongkat dan memberikan kepada siswa, setelah itu guru memberikan pertanyaan dan siswa yang memegang tongkat tersebut harus menjawabnya, demikian seterusnya sampai sebagian besar siswa mendapat bagian untuk menjawab setiap pertanyaan dari guru.

- Guru memberikan kesimpulan.

- Evaluasi.

- Penutup.

\section{p) Bertukar Pasangan}

Langkah-langkah:

- Setiap siswa mendapat satu pasangan (guru bisa menunjuk pasangannya atau siswa memilih sendiri pasangannya). 
- Guru memberikan tugas dan siswa mengerjakan tugas dengan pasangannya.

- Setelah selesai setiap pasangan bergabung dengan satu pasangan yang lain.

- Kedua pasangan tersebut bertukar pasangan, kemudian pasangan yang baru ini saling menanyakan dan mencari kepastian jawaban mereka.

- Temuan baru yang didapat dari pertukaran pasangan kemudian dibagikan kepada pasangan semula.

\section{q) Snowball Throwing}

Langkah-langkah:

- Guru menyampaikan materi yang akan disajikan.

- Guru membentuk kelompok-kelompok dan memanggil masing-masing ketua kelompok untuk memberikan penjelasan tentang materi.

- Masing-masing ketua kelompok kembali ke kelompoknya masing-masing, kemudian menjelaskan materi yang disampaikan oleh guru kepada temannya

- Kemudian masing-masing siswa diberikan satu lembar kertas kerja, untuk menuliskan satu pertanyaan apa saja yang menyangkut materi yang sudah dijelaskan oleh ketua kelompok.

- Kemudian kertas yang berisi pertanyaan tersebut dibuat seperti bola dan dilempar dari satu siswa ke siswa yang lain selama \pm 15 menit.

- Setelah siswa dapat satu bola/satu pertanyaan diberikan kesempatan kepada siswa untuk menjawab pertanyaan yang tertulis dalam kertas berbentuk bola tersebut secara bergantian.

- Evaluasi.

- Penutup

r) Student Facilitator and Explaining 
Langkah-langkah:

- Guru menyampaikan kompetensi yang ingin dicapai.

- Guru mendemonstrasikan/menyajikan materi.

- Memberikan kesempatan siswa untuk menjelaskan kepada siswa lainnya misalnya melalui bagan/peta konsep.

- Guru menyimpulkan ide/pendapat dari siswa

- Guru menerangkan semua materi yang disajikan saat itu

- Penutup.

\section{s) Demonstration}

Langkah-langkah

- Guru menyampaikan kompetensi yang ingin dicapai

- Guru menyajikan gambaran sekilas materi yang akan disampaikan

- Menyiapkan bahan atau alat yang diperlukan.

- Menunjuk salah seorang siswa untuk mendemontrasikan sesuai skenario yang telah disiapkan.

- Seluruh siswa memperhatikan demontrasi dan menganalisanya.

- Tiap siswa mengemukakan hasil analisanya dan juga pengalaman siswa didemontrasikan.

- Guru membuat kesimpulan.

\section{t) Mind Mapping}

Langkah-langkah:

- Guru menyampaikan kompetensi yang ingin dicapai.

- Guru mengemukakan konsep/permasalahan yang akan ditanggapi oleh siswa dan sebaiknya permasalahan yang mempunyai alternatif jawaban

- Membentuk kelompok yang anggotanya 2-3 orang.

- Tiap kelompok menginventarisasi/mencatat alternatif jawaban hasil diskusi. 
- Tiap kelompok (atau diacak kelompok tertentu) membaca hasil diskusinya dan guru mencatat di papan dan mengelompokkan sesuai kebutuhan guru.

- Dari data-data di papan siswa diminta membuat kesimpulan atau guru memberi perbandingan sesuai konsep yang disediakan guru.

\section{u) Tebak Kata}

Langkah-langkah :

- Guru menjelaskan kompetensi yang ingin dicapai atau materi \pm 45 menit.

- Guru menyuruh peserta didik berdiri berpasangan di depan kelas

- Seorang peserta didik diberi kartu yang berukuran 10 x 10 $\mathrm{cm}$ yang nanti dibacakan pada pasangannya. Seorang peserta didik yang lainnya diberi kartu yang berukuran $5 \times 2 \mathrm{~cm}$ yang isinya tidak boleh dibaca (dilipat) kemudian ditempelkan di dahi atau diselipkan ditelinga. Peserta didik yang membawa kartu $10 \times 10 \mathrm{~cm}$ membacakan kata-kata yang tertulis didalamnya sementara pasangannya menebak apa yang dimaksud dalam kartu 10 x $10 \mathrm{~cm}$. Jawaban tepat bila sesuai dengan isi kartu yang ditempelkan tsb.

- Apabila jawabannya tepat (sesuai yang tertulis di kartu) maka pasangan itu boleh duduk. Bila belum tepat pada waktu yang telah ditetapkan, peserta didik boleh mengarahkan dengan kata-kata lain asal jangan langsung memberi jawabannya.

- Dan seterusnya

\section{v) Koperatif (CL, Cooperative Learning)}

Pembelajaran koperatif sesuai dengan fitrah manusis sebagai makhluk sosial yang penuh ketergantungan dengan orang lain, mempunyai tujuan dan tanggung jawab bersama, pembagian tugas, dan rasa senasib. Dengan memanfaatkan kenyatan itu, 
belajar berkelompok secara koperatif, siswa dilatih dan dibiasakan untuk saling berbagi (sharing) pengetahuan, pengalaman, tugas, tanggung jawab. Saling membantu dan berlatih beinteraksi-komunikasi-sosialisasi karena koperatif adalah miniature dari hidup bermasyarakat, dan belajar menyadari kekurangan dan kelebihan masing-masing.Jadi model pembelajaran koperatif adalah kegiatan pembelajaran dengan cara berkelompok untuk bekerja sama saling membantu mengkontruksi konsep, menyelesaikan persoalan, atau inkuiri. Menurut teori dan pengalaman agar kelompok kohesif (kompak-partisipatif), tiap anggota kelompok terdiri dari 4-5 orang, siswa heterogen (kemampuan, gender, karekter), ada control dan fasilitasi, dan meminta tanggung jawab hasil kelompok berupa laporan atau presentasi.Sintaks pembelajaran koperatif adalah informasi, pengarahan-strategi, membentuk kelompok heterogen, kerja kelompok, presentasi hasil kelompok, dan pelaporan.

\section{w) Kontekstual (CTL, Contextual Teaching and Learning)}

Pembelajaran kontekstual adalah pembelajaran yang dimulai dengan sajian atau tanya jawab lisan (ramah, terbuka, negosiasi) yang terkait dengan dunia nyata kehidupan siswa (daily life modeling), sehingga akan terasa manfaat dari materi yang akan disajkan, motivasi belajar muncul, dunia pikiran siswa menjadi konkret, dan suasana menjadi kondusif nyaman dan menyenangkan. Pensip pembelajaran kontekstual adalah aktivitas siswa, siswa melakukan dan mengalami, tidak hanya menonton dan mencatat, dan pengembangan kemampuan sosialisasi. Ada tujuh indokator pembelajarn kontekstual sehingga bisa dibedakan dengan model lainnya, yaitu modeling (pemusatan perhatian, motivasi, penyampaian kompetensi-tujuan, pengarahan-petunjuk, rambu-rambu, contoh), questioning (eksplorasi, membimbing, menuntun, mengarahkan, mengembangkan, evaluasi, inkuiri, 
generalisasi), learning community (seluruh siswa partisipatif dalam belajar kelompok atau individual, minds-on, hands-on, mencoba, mengerjakan), inquiry (identifikasi, investigasi, hipotesis, konjektur, generalisasi, menemukan), constructivism (membangun pemahaman sendiri, mengkonstruksi konsepaturan, analisis-sintesis), reflection (reviu, rangkuman, tindak lanjut), authentic assessment (penilaian selama proses dan sesudah pembelajaran, penilaian terhadap setiap aktvitas-usaha siswa, penilaian portofolio, penilaian seobjektif-objektifnya darei berbagai aspek dengan berbagai cara).

\section{x) Keliling Kelompok}

Maksudnya agar masing-masing anggota kelompok mendapat kesempatan untuk memberikan kontribusi mereka dan mendengarkan pandangan dan pemikiran anggota lainnya

Caranya:

- Salah satu peserta didik dalam masing-masing kelompok menilai dengan memberikan pandangan dan pemikirannya mengenai tugas yang sedang mereka kerjakan

- Peserta didik berikutnya juga ikut memberikan kontribusinya

- Demikian seterusnya giliran bicara bisa dilaksanakan arah perputaran jarum jam atau dari kiri ke kanan

\section{y) Inside Outside Circle (IOC)}

\section{- Pengertian IOC}

Pembelajaran Inside Outside Circle adalah model pembelajaran yang dikembangkan oleh Spencer Kagan untuk memberikan kesempatan pada peserta didik agar saling berbagi informasi pada saat yang bersamaan. Pembelajaran Inside Outside Circle mengembangkan sebuah pembelajaran yang inovatif dan variatif, Lie (2008:65). Inside Outside Circle merupakan pembelajaran yang menepatkan mahasiswa saling membagi informasi dan berinteraksi pada saat yang bersamaan dengan pasangan yang berbeda secara singkat dan teratur 
dengan pola lingkaran dalam dan lingkaran luar. Dari penjelasan diatas bahwa model pembelajaran Inside Outside Circle yang berbentuk kelompok lingkaran dalam dan luar yang menekankan aktivitas mahasiswa untuk aktif dalam berbagi informasi serta saling berinteraksi dengan temanya dan menggunakan rentangan waktu setiap kali terjadi perputaran lingkaran.

\section{- Langkah-langkah Model Pembelajaran IOC ( Inside- outside circle)}

Langkah-langkah Pembelajaran Inside-Outside-Circle menurut Huda (2011:145) adalah sebagai berikut:

\section{Lingkaran Individu}

1) Separuh kelas (atau seperempat jika jumlah Mahasiswa terlalu banyak) berdiri membentuk lingkaran kecil; mereka berdiri menghadap kedalam. Pola bentukan dari kedua lingkaran ini adalah: mahasiswa-mahasiswa dalam lingkaran kecil akan berada di dalam lingkaran mahasiswa-mahasiswa yang membentuk lingkaran besar, sehingga setiap mahasiswa dalam lingkaran kecil nantinya akan berhadapan dengan mahasiswa yang berada di lingkaran besar. Masingmasing akan menjadi pasangan.

2) Misalnya, anggap saja dalam satu ruang kelas terdapat 30 mahasiswa. Mahasiswa 1-15 membentuk lingkaran dalam, sedangkan mahasiswa 16-30 membentuk lingkaran luar. Mahasiswa 1 akan berhadapan dengan mahasiswamahasiswa 16; mahasiswa 2 akan berhadapan dengan mahasiswa 17; mahasiswa 3 akan berhadapan dengan mahasiswa 18; begitu seterusnya dalam bentuk lingkaran.

3) Setiap pasangan mahasiswa dari lingkaran kecil dan besar saling berbagi informasi. Mahasiswa yang berada di lingkaran kecil (lingkaran dalam) dipersilahkan memulai terlebih dahulu. Pertukaran informasi ini bisa dilakukan oleh semua pasangan dalam waktu yang bersamaan, namun tetap 
dengan nada bicara tenang (tidak terlalu keras). Setelah itu, mahasiswa yang berada di lingkaran besar (lingkaran luar) di persilahkan untuk berbagi informasi.

4) Kemudian, mahasiswa yang berada di lingkaran kecil diam di tempat, sementara mahasiswa yang berada di lingkaran besar bergeser satu atau dua langkah searah perputaran jarum jam. Dengan cara ini masing-masing mahasiswa mendapatkan pasangan yang baru untuk berbagi informasi lagi.

5) Sekarang, giliran mahasiswa yang berada di lingkaran besar yang membagikan informasi. Demikian seterusnya.

\section{Lingkaran Kelompok}

1) Satu kelompok berdiri di lingkaran kecil menghadap keluar. Kelompok lain berdiri di lingkaran besar.

2) Setiap kelompok berputar seperti prosedur lingkaran individu yang di jelaskan di atas sambil saling berbagi informasi. (Informasi ini bergantung bagi dosen: apakah mereka diminta untuk bertanya beberapa hal penting terkait dengan hobi, citacita, atau hal-hal lain berhubungan dengan tugas pembelajaran).

\section{- Manfaat Model Pembelajaran IOC} Manfaat bagi mahasiswa, antara lain;

1) Membantu peserta didik meningkatkan pemahaman materi pembelajaran,

2) Meningkatkan rasa percaya diri peserta didik

3) Mengaktifkan peserta didik dalam pembelajaran sehingga memperoleh hasil maksimal,

4) Menumbuhkan motivasi belajar peserta didik.

Manfaat bagi dosen, antara lain;

1) Membantu dosen memperbaiki metode pembelajaran,

2) Membantu dosen berkembang secara profesional,

3) Menumbuhkan rasa peraya diri dosen, 
4) Memungkinkan dosen secara aktif mengembangkan pengetahuan dan ketrampilan.

- Kekurangan dan Kelebihan Model Pembelajaran IOC Kelebihan penggunaan Model IOC , antara lain;

1) Siswa akan mudah mendapatkan informasi yang berbedabeda dan beragam dalam waktu bersamaan,

2) Tidak ada bahan spesifikasi yang dibutuhkan untuk strategi, sehingga dapat dengan mudah di masukkan ke dalam pelajaran,

3) Kegiatan ini dapat membangun sifat kerjasama antar mahasiswa.

Kekurangan penerapan Model IOC, antara lain;

1) Membutuhkan ruang kelas yang besar,

2) Terlalu lama sehingga tidak konsentrasi dan disalah gunakan untuk bergurau,

3) Rumit untuk dilakukan.

\section{Contoh Penerapan Model IOC (Inside-Outside Circle) Dalam mata kuliah Belajar dan Pembelajaran}

Pada penerapan Model IOC ini, sebagai contoh akan diterapkan pada mata kuliah belajar dan pembelajaran, berikut rangkaian pelaksanaan pembelajaran sebagai berikut;

1) Dosen memberikan salam dan menanyakan kabar untuk membuka pelajaran.

2) Mengkondisikan serta memeriksa kehadiran mahasiswa dan memastikan mahasiswa siap menerima pelajaran.

3) Dosen mengajak mahasiswa untuk berdoa sebelum memulai pembelajaran.

4) Dosen mengulang pelajaran sebelumnya dan memberikan pertanyaan pancingan sebagai pembuka pelajaran

5) Menyampaikan kompetensi yang akan dicapai mahasiswa

6) Menyampaikan tahapan kegiatan pembelajaran

7) Dosen menampilkan gambar, mahasiswa diminta mengamati gambar. 
8) Dosen memberikan kertas yang berisi informasi tentang pelajaran pada pertemuan ini

9) Setelah selesai dosen membentuk mahasiswa menjadi beberapa kelompok.

10) Separuh kelas (atau seperempat jika jumlah mahasiswa terlalu banyak) berdiri membentuk lingkaran kecil; mereka berdiri menghadap kedalam. Pola bentukan dari kedua lingkaran ini adalah: mahasiswa-mahasiswa dalam lingkaran kecil akan berada di dalam lingkaran mahasiswa-mahasiswa yang membentuk lingkaran besar, sehingga setiap mahasiswa dalam lingkaran kecil nantinya akan berhadapan dengan mahasiswa yang berada di lingkaran besar. Masing-masing akan menjadi pasangan.

11) Misalnya, anggap saja dalam satu ruang kelas terdapat 30 mahasiswa. Mahasiswa 1-15 membentuk lingkaran dalam, sedangkan mahasiswa 16-30 membentuk lingkaran luar. Mahasiswa 1 akan

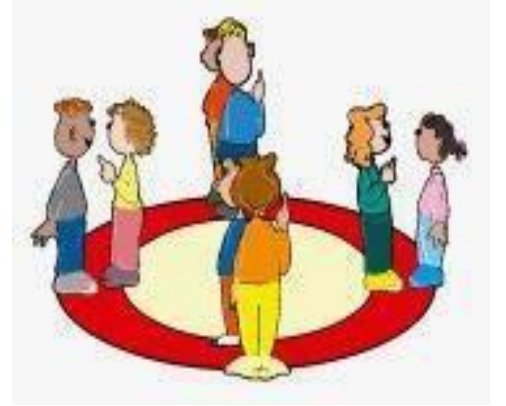
berhadapan dengan mahasiswa 16; mahasiswa 2 akan berhadapan dengan mahasiswa 17; mahasiswa 3 akan berhadapan dengan mahasiswa 18; begitu seterusnya dalam bentuk lingkaran.

12) Setiap pasangan mahasiswa dari lingkaran kecil dan besar saling berbagi informasi. Mahasiswa yang berada di lingkaran kecil (lingkaran dalam) dipersilahkan memulai terlebih dahulu. Pertukaran informasi ini bisa dilakukan oleh semua pasangan dalam waktu yang bersamaan, namun tetap dengan nada bicara tenang (tidak terlalu keras). Setelah itu, mahasiswa yang berada di lingkaran besar (lingkaran luar) di persilahkan untuk berbagi informasi.

13) Kemudian, mahasiswa yang berada di lingkaran kecil diam di tempat, sementara mahasiswa yang berada di lingkaran besar 
bergeser satu atau dua langkah searah perputaran jarum jam.

Dengan cara ini masing-masing mahasiswa mendapatkan pasangan yang baru untuk berbagi informasi lagi.

14) Sekarang, giliran mahasiswa yang berada di lingkaran besar yang membagikan informasi. Demikian seterusnya.

15) Kemudian setelah semua mahasiswa mendapatkan informasi, mahasiswa kembali ke kelompoknya untuk mendiskusikan hasil informasi yang didapat.

16) Selanjutnya perwakilan kelompok (kelompok besar dan kelompok kecil menyampaikan hasil diskusinya di depan kelas.

17) Dosen menyimpulkan dan mengulang materi pembelajaran yang sudah disampaikan.

18) Dosen memberikan soal PR kepada mahasiswa.

19) Dosen menutup pelajaran dengan membaca do'a bersama.

\section{PENGERTIAN METODE}

Metode berasal dari Bahasa Yunani methodos yang berarti cara atau jalan yang ditempuh. Sehubungan dengan upaya ilmiah, maka, metode menyangkut masalah cara kerja untuk dapat memahami objek yang menjadi sasaran ilmu yang bersangkutan. Fungsi metode berarti sebagai alat untuk mencapai tujuan, atau bagaimana cara melakukan atau membuat sesuatu.

Pengertian metode adalah suatu proses atau cara sistematis yang digunakan untuk mencapai tujuan tertentu dengan efisiensi, biasanya dalam urutan langkah-langkah tetap yang teratur. Kata metode (method) berasal dari bahasa Latin dan juga Yunani, methodus yang berasal dari kata meta yang berarti sesudah atau di atas, dan katahodos, yang berarti suatu jalan atau suatu cara.

Metode pembelajaran adalah suatu proses penyampaian materi pendidikan kepada peserta didik yang dilakukan secara sistematis dan teratur oleh tenaga pengajar atau guru.

\section{METODE PEMBELAJARAN}

Proses belajar memerlukan metode-metode khusus yang jelas untuk mencapai tujuan pembelajaran yang efektif dan efisien. Metode 
pembelajaran merupakan cara-cara dalam melakukan aktivitas antara pendidik dan peserta didik ketika berinteraksi dalam proses belajar. Pendidik perlu mengetahui dan mempelajari metode pengajaran agar dapat menyampaian materi dan dimengerti dengan baik oleh peserta didik. Metode pengajaran dipraktekkan pada saat mengajar dan dibuat semenarik mungkin agar peserta didik mendapat pengetahuan dengan efektif dan efisien. Adapun definisi Metode Pembelajaran menurut beberapa para ahli sebagai berikut;

1. Hasby Ashydiqih, metode pembelajaran adalah seperangkat cara yang dilakukan guna mencapai tujuan tertentu dalam proses pembelajaran.

2. Abdurrahman Ginting, metode pembelajaran adalah cara atau pola yang khas dalam memanfaatkan berbagai prinsip dasar pendidikan serta berbagai teknik dan sumber daya terkait lainnya supaya terjadi proses pembelajaran pada diri siswa.

3. Ahmadi, metode pembelajaran adalah suatu pengetahuan tentang beberapa cara mengajar yang dipergunakan oleh guru atau instruktur.

4. Nana Sudjana, metode pembelajaran adalah cara yang dipergunakan guru dalam mengadakan hubungan dengan siswa pada saat berlangsungnya proses belajar dan mengajar.

5. Sobri Sutikno, metode pembelajaran adalah cara-cara dalam menyajikan materi pelajaran yang diberikan kepada murid agar terjadi proses pembelajaran pada diri siswa dalam upaya untuk mencapai tujuan.

Berdasarkan uraian di atas dapat disimpulkan bahwa yang dimaksud metode pembelajaran adalah cara atau jalan yang ditempuh oleh guru untuk menyampaikan materi pembelajaran sehingga tujuan pembelajaran dapat dicapai.Dapat juga disimpulkan bahwa metode pembelajaran adalah strategi pembelajaran yang digunakan oleh guru sebagai media untuk mencapai tujuan pembelajaran yang telah ditetapkan. Hal ini mendorong seorang guru untuk mencari metode yang tepat dalam menyampaian materinya agar dapat diserap dengan 
baik oleh siswa. Mengajar secara efektif sangat bergantung pada pemilihan dan penggunaan metode mengajar. Adapun metode-metode pengajaran dalam proses belajar sebagai berikut; (Filediamant, 2012).

\section{Metode Konvensional/metode ceramah}

Metode pengajaran dengan cara berceramah atau menyampaikan informasi secara lisan kepada siswa. Metode ini merupakan metode yang paling praktis dan ekonomis, tidak membutuhkan banyak alat bantu. Metode ini mampu digunakan untuk mengatasi kelangkaan literatur atau sumber rujukan informasi karena daya beli siswa yang diluar jangkauan. Namun metode ini juga memiliki beberapa kelemahan dan kelebihan.

\section{Kekurangan metode ceramah yaitu:}

a) Siswa menjadi pasif.

b) Proses belajar membosankan dan siswa mengantuk.

c) Terdapat unsur paksaan untuk mendengarkan.

d) Siswa dengan gaya belajar visual akan bosan dan tidak dapat menerima informasia tau pengetahuan, pada anak dengan gaya belajar auditori hal ini mungkin cukup menarik.

e) Evaluasi proses belajar sulit dikontrol, karena tidak ada poin pencapaian yang jelas.

f) Proses pengajaran menjadi verbalisme atau berfokus pada pengertian kata- kata saja.

Kelebihan dari metode ini juga ada, antara lain:

a) Mendorong siswa untuk menjadi lebih fokus.

b) Guru dapat mengendalikan kelas secara penuh.

c) Guru dapat menyampaikan pelajaran yang luas.

d) Dapat diikuti oleh jumlah anak didik yang banyak.

e) Mudah dilaksanakan.

\section{Metode Diskusi}

Metode diskusi merupakan metode pengajaran yang erat hubungannya dengan belajar pemecahan masalah. Metode ini juga biasa dilakukan secara berkelompok atau diskusi kelompok.

Kelebihan metode diskusi kelompok ini, sebagai berikut: 
a) Memberikan pemahaman pada anak didik bahwa setiap permasalahan pasti ada penyelesaiannya.

b) Siswa mampu berfikir kritis.

c) Mendorong siswa untuk dapat menyampaikan pendapatnya.

d) Mengambil satu atau lebih alternatif pemecahan masalah.

e) Mendorong siswa memberikan masukan untuk pemecahan masalah.

f) Siswa menjadi paham tentang toleransi pendapat dan juga mendengarkan orang lain.

Kekurangan dari metode diskusi ini yaitu sebagai berikut:

a) Cocok digunakan untuk kelompok kecil.

b) Tema diskusi terbatas.

c) Dikuasai oleh orang orang yang suka berbicara.

d) Dibutuhkan penyampaian secara formal dalam berpendapat.

\section{Metode Demostrasi}

Metode demonstrasi digunakan pada pengajaran dengan proses yaitu menggunakan benda atau bahan ajar pada saat pengajaran. Bahan ajar akan memberikan pandangan secara nyata terhadap apa yang akan dipelajari, bisa juga melalui bentuk praktikum. Metode demonstrasi ini memiliki manfaat antara lain siswa jadi lebih tertarik dengan apa yang diajarkan, siswa lebih fokus dan terarah pada materi, pengalaman terhadap pengajaran lebih diingat dengan baik oleh siswa.

\section{Kelebihan metode demonstrasi ini, antara lain:}

a) Siswa bisa memahami secara lebih jelas tentang suatu proses atau cara kerja.

b) Penjelasan menjadi lebih mudah dimengerti.

c) Meminimalisir kesalahan dalam menyampaikan materi lisan, karena bukti konkret bisa dilihat.

\section{Kekurangan dari metode demonstrasi ini, yaitu:}

a) Apabila benda yang didemonstrasikan terlalu kecil, siswa kesulitan dalam mengamati. 
b) Jumlah siswa yang terlalu banyak dapat menghalangi pandangan siswa secara merata.

c) Tidak semua materi bisa didemonstrasikan.

d) Memerlukan guru yang benar- benar paham, agar bisa mendemonstrasikan dengan baik.

\section{Metode Ceramah Plus}

Metode ceramah plus yaitu sistem pengajaran dengan menggunakan ceramah lisan dan disertai metode lainnya. Metode mengajar ini menggunakan lebih dari satu metode. Misalnya:

a) Metode ceramah plus tanya jawab: Metode ini secara ideal disertai dengan penyampaian materi dari guru, pemberian peluang pada siswa untuk bertanya apa yang tidak dimengerti, dan pemberian tugas di akhir pengajaran.

b) Metode ceramah plus diskusi dan tugas: Metode ini dilakukan dengan memberikan materi secara lisan kemudian disertai dengan diskusi dan pemberian tugas di akhir sesi.

c) Metode ceramah plus demonstrasikan dan latihan: Metode ini merupakan gabungan dari penyampaian materi dengan memperagakan atau latihan atau percobaan.

\section{Metode Resitasi}

Metode resitasi merupakan metode mengajar dengan siswa diharuskan membuat resume tentang materi yang sudah disampaiakan guru, dengan menuliskannya pada kertas dan menggunakan bahasa sendiri.

\section{Kelebihan metode resitasi, sebagai berikut:}

a) Siswa menjadi lebih ingat dengan materi, karena telah menuliskannya dengan resume.

b) Menurut Sayiful Bahri, 2000 siswa menjadi lebih berasi dalam mengambil inisiatif dan mampu bertanggungjawab.

\section{Kekurangan metode resitasi, yaitu:}

a) Hasil resume yang dilakukan terkadang hanya mencontek pada teman dan bukan hasil pikirannya sendiri.

b) Tugas bisa jadi dikerjakan oleh orang lain. 

c) Susah mengevaluasi apakah siswa benar- benar memahami hasil tulisan resumenya sendiri.

\section{Metode Percobaan}

Metode percobaan merupakan metode pengajaran dengan menggunakan action berupa praktikum atau percobaan lab. Masing masing siswa dengan ini mampu melihat proses dengan nyata dan belajar secara langsung.

\section{Kelebihan dari metode percobaan ini, yaitu:}

a) Metode ini membuat siswa merasa bahwa materi yang dipelajari benar adanya dengan dibuktikan melalui percobaan.

b) Siswa dapat mengembangkan diri dengan mengadakan eksplorasi dengan percobaan percobaan.

c) Metode ini akan menghasilkan siswa dengan jiwa peneliti dan suka mencaritahu dan pengembangan keilmuan dan memberikan kesejahteraan pada masyarakat.

\section{Kekurangan dari metode percobaan ini, yaitu:}

a) Kekurangan alat seringkali menghambat siswa untuk dapat bereksperimen lebih.

b) Eksperimen dilakukan pada jam kelas yang terbatas, sehingga percobaan yang dapat dilakukan terbatas

c) Metode ini cocok untuk beberapa tipe pelajaran saja, seperti biologi, teknologi, dan lainnya.

\section{Metode Karya Wisata}

Metode karya wisata adalah suatu metode mengajar dengan memanfaatkan lingkungan, lokasi, atau tempat- tempat yang memiliki sumber pengetahuan bagi siswa. Metode mengajar ini dilakukan dengan pendampingan oleh guru ataupun orang tua jika usianya masih terlalu muda. Pendampingan dilakukan untuk menunjukkan sumber pengetahuan yang perlu dipahami oleh siswa. Metode karya wisata ini bisa dilakukan di tempat tempat sejarah, di alam, atau lainnya.

Kelebihan metode karya wisata, antara lain: 
a) Metode ini merupakan metode modern yang memanfaatkan interaksi dengan lingkungan nyata.

b) Bahan yang dipelajari ketika sekolah, bisa langsung dilihat secara nyata misalnya bangunan bersejarah.

c) Pengajaran dengan metode ini bisa merangsang siswa untuk lebih kreatif.

d) Metode pengajan ini sangat menyenangkan dan tidak jenuh.

Kekurangan metode karya wisata, antara lain:

a) Memerlukan perencanaan yang matang.

b) Memerlukan persiapan yang disetujui oleh banyak pihak.

c) Seringkali metode belajar ini lebih mengutamakan tujuan rekreasi daripada tujuan pembelajarannya.

d) Membutuhkan biaya yang cukup mahal.

e) Memerlukan pengawasan dari pihak guru dan orang tua.

f) Keselamatan dan perlindungan menjadi faktor penting.

\section{Metode Latihan Keterampilan}

Metode latihan keterampilan ini merupakan metode mengajar dengan melatih keterampilan siswa atau soft skill dengan cara membuat, merancang, atau memanfaatkan sesuatu. Metode ini membutuhkan kreativitas siswa yang tinggi denganmemanfaatkan suatu bahan menjadi barang yang lebih berguna dan bermanfaat.

Kelebihan metode latihan ketrampilan ini, yaitu:

a) Metode ini melatih kecakapan motorik dan kognitif anak dengan menggunakan alat alat dan kemampuan mengolah bahan menjadi ide yang lebih kreatif.

b) Melatih kreativitas seni siswa.

c) Melatih fokus, ketelitian, kecepatan dan ketepatan.

Kekurangan metode latihan ketrampilan, yaitu:

a) Siswa yang tidak memiliki minat akan kesulitan untuk menyesuaikan diri.

b) Menghambat bakat siswa yang lainnya, sehingga lebih baik disesuaikan dengan bakat masing- masing. 
c) Waktu yang terlalu lama dalam melaksanalan latihan bisa menimbulkan kebosanan dan kehilangan minat dari siswa.

\section{Metode Pemecahan Masalah (Problem Based Learning)}

Metode PBL ini dilakukan dalam kelas kecil, siswa diberikan kasus untuk menstimulasi diskusi kelompok. Kemudian siswa mengutarakan hasil pencarian materi terkait kasus dan didiskusikan dalam kelompok.

\section{Kelebihan metode problem based learning adalah:}

a) Siswa menjadi lebih aktif dalam mencari materi atau informasi terkait kasus.

b) Siswa aktif dalam menyampaikan pendapat dan berdiskusi.

c) Suasana kelas tidak membosankan dan menyita fokus siswa.

Kekurangan metode problem based learning, yaitu:

a) Metode ini lebih tepat dilakukan dalam kelas kecil dengan jumlah siswa yang tidak terlalu banyak.

b) Perlu adanya trigger atau kasus pemicu yang baik agar diskusi dapat terarah sesuai tujuan pembelajaran.

c) Perlu adanya mentor atau pembimbing yang bertugas meluruskan alur diskusi.

d) Diskusi bisa berjalan terlalu panjang lebar pada satu topik bahasan dan memakan waktu apabila semua siswa berpendapat pada satu topik.

e) Pendapat siswa mungkin sama atau mirip yang seharusnya sudah tidak perlu disampaikan lagi.

\section{Metode Perancangan}

Metode perancangan merupakan metode mengajar dengan merangsang siswa untuk mampu menciptakan atau membuat suatu proyek ayang akan dipraktekkan atau akan diteliti.

Kelebihan metode ini yaitu:

a) Membangun pola pikir kritis dan kreatif siswa sehingga lebih luas dan mampu memecahkan masalah. 
b) Metode ini mengasah siswa untuk dapat mengintegrasikan pengetahuan, sikap, dan ketrampilan secara terpadu dan berguna nyata dalam kehidupan sehari hari.

\section{Kekurangan metode perancangan ini yaitu:}

a) Kurikulum yang ada belum menunjang metode pengajaran ini. Metode ini hanya bisa dipelajari atau diperoleh ketika ada event perlombaan.

b) Dibutuhkan bimbingan dari guru yang khusus dalam melakukan perencanaan dan pelaksanaan

c) Membutuhkan fasilitas dan sumber yang mendukung pelaksanaan.

\section{Metode Discovery}

Metode discovery merupakan metode pengajaran modern yang dilakukan dengan cara mengembangkan cara belajar siswa menjadi lebih aktif, mandiri, dan pemahaman yang lebih baik. Siswa mencari jawaban atas pertanyaannya sendiri, sehingga dapat diingat lebih baik. Strategi ini dinamakan strategi penemuan. Siswa menjadi lebih aktif mencari, memahami, dan menemukan jawaban atau materi terkait. Siswa juga mampu menganalisa pengetahuan yang diperolehnya kemudian ditransfer kepada masyarakat.

\section{Kelebihan metode discovery, yaitu:}

a) Mengembangkan kognitif siswa dan memperbanyak penguasaan ketrampilan.

b) Pengetahuan diperoleh dengan caranya sendiri sehingga menjadi lebih mandiri dan berfikir lebih luas

c) Dapat menyesuaikan kemampuan siswa itu sendiri.

d) Mengarahkan siswa untuk dapat bergerak maju dan meningkatkan motivasi diri dalam belajar.

e) Meningkatkan rasa percaya diri melalui penemuan penemuannya.

f) Meningkatkan interaksi antara siswa dengan guru.

Kekurangan metode discovery, antara lain:

a) Diperlukan persiapan mental dalam proses belajar ini. 
b) Metode ini baik untuk kelas kecil.

c) Mengejarkan tentang penemuan lebih mementingkan tentang pengertian daripada memperhatikan yang diperolehnya dari ketrampilan dan sikap.

d) Ide- ide mungkin sulit ditemukan.

e) Tidak semua penemuan menjelaskan pemecahan terhadap masalah.

\section{Metode Inquiry}

Metode inquiry merupakan metode yang mampu membangun siswa untuk menyadari apa yang dia dapatkan selama belajar. Guru tetap memiliki peranan penting dalam metode ini yaitu dengan membuat design pengalaman belajar. Inquiry memiliki arti memahami apa yang telah dilalui. Metode ini melibatkan intelektual dan menuntut siswa memahami apa yang mereka pelajari sebagai sesuatu yang berharga. Strategi pelaksanaan metode inquiry ini yaitu: guru memberikan penjelasan materi yang diajarkan, kemudian memberikan tugas pada siswa untuk menjawab pertanyaan yang diajukan guru sebagai evaluasi pemahaman siswa. Guru membantu memberikan jawaban yang mungkin sulit dan membingungkan bagi siswa. Resitasi dilakukan pada akhir untuk mengevaluasi pemahaman siswa tentang apa yang sudah dipelajari. Kemudian siswa merangkum apa saja yang sudah dipelajari sebagai kesimpulan yang dapat dipertanggunjawabkan.

\section{Metode Mind Mapping}

Mind mapping adalah metode belajar dengan menerapkan cara berfikir runtun terhadap suatu permasalahan bagaimana bisa terjadi sampai pada penyelesaiannya. Pengajaran melalui mind mapping disajikan dalam bentuk skema yang memiliki hubungan sebab akibat dan saling berpengaruh. Metode belajar dengan mind mapping ini mampu meningkatkan analisis dan berfikir kritis siswa sehingga memahami sesuatu secara keseluruhan dari awal sampai akhir. 


\section{Kelebihan mind mapping, antara lain:}

a) Cara ini lebih efektif dan efisien.

b) Ide ide baru bisa muncul dengan menggambar diagram diagram.

c) Digram yang terbentuk bisa menjadi alur berfikir yang efektif dan bermanfaat untuk hal lain.

Kekurangan dari model mind mapping, adalah:

a) Hanya siswa yang aktif yang mampu terlibat.

b) Memerlukan dasar dengan banyak membaca sebelum membuat mapping.

c) Beberapa detail informasi tidak masuk dalam mapping.

d) Orang lain mungkin tidak dapat memahami mind mapping yang dibuat oleh orang lain karena hanya berupa poin inti saja yang dituliskan.

e) Beberapa orang kesulitan merangkai panah atau alur mind mapping dengan rapi, dan seringkali mind mapping terkesan berantakan dan tidak dapat dipahami.

\section{Metode Role Playing/ Berbagi peran}

Metode pembelajaran dengan role playing yaitu dengan metode drama atau peran. Metode ini dengan melibatkan siswa dalam berakting sebagai suatu karakter dalam suatu situasi tertentu dan menunjukkan respon yang seharusnya dilakukan. Pembelajaran melalui role playing ini melatih interaksi dan mengekspresikan diri secara nyata sebagai contoh atas kejadian yang sebenarnya. Hal ini juga bisa digunakan untuk latihan komunikasi yang baik, atau interaksi dengan orang lain atau klien.

\section{Kelebihan metode role playing:}

a) Siswa mampu mempraktikkan secara langsung.

b) Melatih rasa percaya diri di depan kelas.

c) Lebih memahami materi.

Kekurangan dari metode role playing ini adalah:

a) Tidak semua siswa menyukai metode pembelajaran ini.

b) Metode ini akan sulit diikuti untuk tipe siswa yang introvert.

\section{Metode Cooperative Script}


Skrip kooperatif merupakan metode belajar dengan memasangkan siswa dan secara lisan menuntut siswa untuk mengutarakan intisari dari bagian materi yang disampaikan. Pertama, guru membagi siswa untuk berpasangan, guru membagikan materi pada siswa dan membuat ringkasan, guru menentukan siapa yang akan menjadi pembicara dan pendengar. Pembicara membacarakan ringkasannya sebaik mungkin dengan mengutarakan ide ide pokok materi, kemudian bertukar peran antara pembicara dan pendengar. Guru pada akhir sesi memberikan kesimpulan.

\section{Kelebihan metode ini yaitu:}

a) Melatih kemampuan berbicara siswa dan juga kemampuan untuk mendengarkan.

b) Partisipasi siswa menjadi aktif secara menyeluruh.

c) Meningkatkan keberanian dan rasa percaya diri.

Kekurangan metode ini, yaitu:

a) Hanya bisa digunakan untuk mata pelajaran tertentu.

b) Hanya dapat dilakukan menjadi dua grup dan berpasangan dua orang.

\section{Metode Debat}

Debat merupakan metode pembelajaran dengan mengadu argumentadi antara dua pihak atau lebih baik perorangan maupun kelompok. Argumentasi yang dilakukan membahas tentang penyelesaian suatu permasalahan dan memberi keputusan terhadap masalah. Debat pada umumnya dilakukan secara formal dengan bahasa bahasa formal dan cara cara tertentu yang sopan. Terdapat aturan aturan dalam debat informasikan yang disajikan harus memuat data yang relevan dan berisi.

\section{Kelebihan metode pembelajaran ini, yaitu:}

a) Melatih kemampuan berpendapat dan mempertahankan pendapat siswa.

b) Melatih kerja kelompok.

c) Menuntut siswa untuk mencari informasi yang kuat untuk argumentasinya. 
d) Melatih rasa percaya diri dalam berpendapat.

Kekurangan dalam metode pembelajaran ini, adalah:

a) Seringkali justru berebut dalam memberikan pendapat,

b) Pendapat tidak memiliki intisari yang informatif dan hanya berisi sanggahan,

c) Adu argumen tidak menemukan titik penyelesaian,

d) Siswa yang tidak pandai berargumen akan cenderung pasif dan hanya orang orang tertentu saja yang aktif berbicara.

\section{Metode Mengajar Beregu (Team Teaching Method)}

Metode mengajar ini dilakukan oleh lebih dari satu pengajar, materi diberikan dengan jadwal yang berbeda oleh beberapa pengajar. Soal ujian dibuat oleh beberapa pengajar dan disatukan. Pengajar membuat soal dengan menggunakan poin poin capaian yang sudah dibuat sehingga jelas.

\section{Metode Mengajar Sesama Teman (Peer Teaching Method)}

Metode mengajar ini dilakukan dengan cara berdiskusi, atau juga dengan presentasihasil diskusi. Kelompok menyampaikan materi hasil diskusi dan memberi kesempatan pada teman- temannya untuk bertanya. Kelompok menjawab setiap pertanyaan.

\section{Metode Bagian (Teileren method)}

Metode pengajaran ini dilakukan denganmemberikan materi sebagian sebagian, misalnya belajar ayat. Pengajaran dimulai dari ayat per ayat yang kemudian disambung lagi dengan ayat lain.

\section{Metode Global}

Metode global ini mengajarkan pada siswa keseluruhan materi, kemudian siswa membuat resume tentang materi tersebut yang mereka serap dan diambil intisarinya.

Metode pembelajaran diatas bertujuan untuk menningkatkan pemahaman peserta didik dalam memperoleh indormasi atau pengetahuan dengan efisien dan efektif. Metode pembelajaran masing-masing memiliki kelebihan dan kekurangannya, sehingga tidak semua metode pembelajaran bisa diterapkan pada semua kelas atau semua mata pelajaran. Guru perlu mencocokkan metode 
pembelajaran mana yang sesuai untuk kelasnya dan seusuai dengan materi yang akan dilakukan agar peserta didik merasa tertarik dalam belajar dan memiliki pemahaman yang baik di akhir pembelajaran. 


\section{BAB IX \\ SUMBER BELAJAR DAN MEDIA PEMBELAJARAN}

Pada dasarnya harus menjadi tantangan bagi semua pihak melakukan beberapa persiapan dan pembenahan, diantaranya dalam mempersiapkan desain dan inovasi-inovasi dibidang sumber belajar, media pembelajaran dan alat peraga.

Kecenderungan dunia kreativitas dari para pendidik untuk bidang-bidang ini akan ditantang, sejauhmana mereka mampu mengimbangi peliknya rumusan-rumusan standar kompetensi yang harus dicapai siswa dalam menempuh KBK ini. Atas pemikiran inilah maka penulis merasa perlu untuk menetengahkan kembali bahan diskusi dalam makalah kecil ini, sebagai stimulus bagi kita semua untuk kembali mampu memikirkan, melakukan-memproduksi, mengujicobakan serta menilainya. Dengan demikian apa yang menjadi tujuan dalam KBK ini diantaranya mampu dioptimalkan pencapaiannya melalui penggunaan dan pemanfaatan sumber belajar, media dan alat peraga.

Akan tetapi dalam pelaksanaannya terutama pada tahap pengenalan dan pemetaan dari ketiga konsep ini, yaitu sumber belajar, media pembelajaran dan alat peraga, kadang kali masih simpang siur. Untuk itu pada awal pembicaraan ini penulis akan memulainya dengan salah satu ilustrasi yang mungkin bisa membawa menjadi bahan diskusi kita untuk kembali melakukan analisis secara lebih cermat.

\section{A. SUMBER BELAJAR}

Dalam proses belajar dan pembelajaran, sumber belajar sangatlah dipentingkan. Sumber belajar adalah segala sesuatu yang dapat dimanfaatkan oleh peserta didik untuk mempelajari bahan dan pengalaman belajar sesuai dengan tujuan yang hendak dicapai (Sanjaya, 2006: 172). Menurut Rohani (1997: 102) sumber belajar (learning resources) " sumber belajar adalah segala macam sumber 
yang ada di luar diri seseorang (peserta didik) dan yang memungkinkan (memudahkan) terjadinya proses belajar".

Sumber belajar adalah sebuah daya yang bisa dimanfaatkan guna kepentingan proses belajar mengajar, baik secara langsung maupun secara tidak langsung,sebagian atau secara keseluruhan (Sudjana dan Rivai, 2009: 76). Pada dasarnya sumber belajar secara umum adalah segala sesuatu yang disekitar speserta didik sebagai sarana belajar dengan tujuan tercapainya tujuan pembelajaran. Sumber belajar sangatlah penting keberadaannya untuk pedoman peserta didik dalam mencari materi dan memecahkan masalah. Peran dari sumber belajar dalam kegiatan belajar dan pembelajaran menurut Musfiqon (2012: 128) sumber belajar merupakan kebutuhan penting yang bisa menjadi sumber belajar, sumber alat, sumber peraga, serta kebutuhan lain yang diperlukan dalam pembelajaran.

\section{B. MACAM-MACAM SUMBER BELAJAR}

Sumber belajar bukan berbentuk satu jenis saja, tetapi didalam sumber belajar memiliki macam-macam bentuk. Sumber belajar dapat diklasifikasikan berdasarkan wujudnya antara lain, Sumber belajar tercetak, Sumber belajar noncetak, Sumber belajar yang berbentuk fasilitas, Sumber belajar yang berupa kegiatan, Sumber belajar berupa lingkungan di masyarakat (Sudjana dan rivai, 2009: 80).

Menurut Soeharto (2003) dalam Musfiqon (2012: 131) "sumber belajar dapat dibedakan menjadi dua, yaitu sumber belajar yang dirancang (by designed) dan sumber belajar yang tinggal dipakai atau jadi (by utilization)". Sumber belajar yang dirancang atau by designed merupakan sumber belajar yang dikembangkan dan diproduksi untuk pembelajaran, sedangkan sumber belajar by ulilization merupakan sumber belajar yang sudah ada dan dimanfaatkan untuk pembelajaran. Sumber belajar ini dibedakan berdasarkan tujuan pembuatannya. Sedangkan sumber belajar berdasarkan cara memperoleh informasinya dapat dibedakan menjadi jenis visual, audio dan audiovisual (Sitepu, 2014: 64). 


\section{MEDIA PEMBELAJARAN}

Ketika mengajar kita memerlukan suatu alat atau media pembelajaran untuk mempermudah kita dalam menyampaiakan materi pembelajaran ke peserta didik. selain mempermudah, juga bisa membuat peserta didik termotivasi untuk mengikuti pelajaran. nah, apa sih media pembelajaran?, pengertian media dapat diartikan sebagai perantara atau penghubung antara dua pihak yakni sumber pesan dan penerima pesan, sehingga media pembelajaran dapat diartikan sesuatu yang mengantarkan pesan pembelajaran antara pemberi pesan dan penerima pesan.

Terdapat banyak definisi media oleh ahli-ahli terkemuka seperti Bretz, Gerlach\&Elly, dan AECT (Association for Educational Communication and technology). Berdasarkan dari berbagai definisi yang dikemukakan oleh ahli-ahli tersebut, dapat diakatakan bahwa media pembelajaran adalah setiap orang, bahan, alat, atau peristiwa yang memungkinkan pebelajar menerima pengetahuan, keterampilan, dan sikap, dengan kata lain bahwa guru/dosen, buku ajar, lingkungan adalah media pembelajaran. Setiap media merupakan saran untuk mencapai tujuan. Didalamnya terkandung informasi yang dapat dikomunikasikan kepada orang lain. Informasi ini mungkin didaoatkan melalui nuku, internet, rekaman, film, mikro film,dsb. Media pembelajaran terdapat dua unsur, yakni perangkat keras (hardware) dan perangkat lunak (software). Contoh dari perangkat keras yakni OHP, slide proyekor, opaque proyektor, LCD proyektor, film proyektor, sedangkan contoh dari software yakni transparansi, film slide, Ms. Power Point, film.

\section{MACAM-MACAM MEDIA PEMBELAJARAN}

Media pembelajaran merupakan kumpulan berbagai jenis komponen yang ada di dalam lingkungan peserta didik sehingga mereka lebih terangsang untuk mengikuti pelajaran dengan baik. Media juga dapat dijadikan sebagai cara

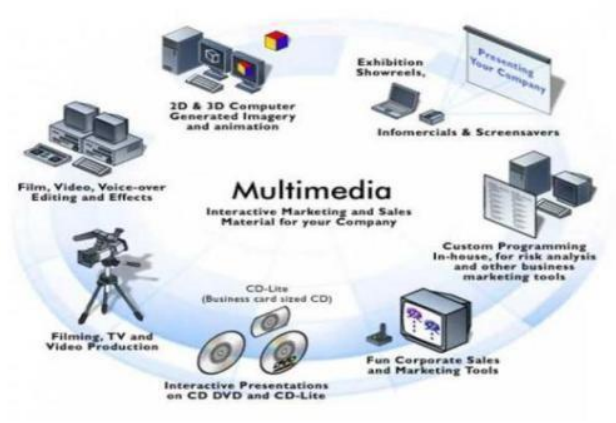


untuk menyalurkan pesan materi kepada peserta didik. Media pembelajaran banyak jenis dan macamnya. Dari yang palng sederhana dan murah hingga yang canggih dan mahal. Ada yang dapat dibuat oleh guru sendiri dan ada yang diproduksi pabrik. Ada yang sudah tersedia di lingkungan untuk langsung dimanfaatkan dan ada yang sengaja dirancang. Berbagai sudut pandang untuk menggolongkan jenis-jenis media. Anderson (1976) menggolongkan menjadi 10 media sebagai berikut;

1. Audio : Kaset audio, siaran radio, $\mathrm{CD}$, telepon

2. Cetak : buku pelajaran, modul, brosur, leaflet, gambar

3. Audio-cetak : kaset audio yang dilengkapi bahan tertulis

4. Proyeksi visual diam : Overhead transparansi (OHT), film bingkai (slide)

5. Proyeksi audio visual diam : film bingkai slide bersuara

6. Visual gerak : film bisu

7. Audio visual gerak : film gerak bersuara, Video/VCD, Televisi

8. Obyek fisik : Benda nyata, model, spesimen

9. Manusia dan lingkungan : guru, pustakawan, laboran

10. Komputer : CAI

Kriteria yang paling utama dalam pemilihan media bahwa media harus disesuaikan dengan tujuan pembelajaran atau kompetensi yang ingin dicapai. Contoh : bila tujuan atau kompetensi peserta didik bersifat menghafalkan kata-kata tentunya media audio yang tepat untuk digunakan. Jika tujuan atau kompetensi yang dicapai bersifat memahami isi bacaan maka media cetak yang lebih tepat digunakan. Kalau tujuan pembelajaran bersifat motorik (gerak dan aktivitas), maka media film dan video bisa digunakan. Di samping itu, terdapat kriteria lainnya yang bersifat melengkapi (komplementer), seperti: biaya, ketepatgunaan; keadaan peserta didik; ketersediaan; dan mutu teknis.

\section{Media Visual}

a) Media yang tidak diproyeksikan 
1) Media realia adalah benda nyata. Benda tersebut tidak harus dihadirkan di ruang kelas, tetapi siswa dapat melihat langsung ke obyek. Kelebihan dari media realia ini adalah dapat memberikan pengalaman nyata kepada siswa. Misal untuk mempelajari keanekaragaman makhluk hidup, klasifikasi makhluk hidup, ekosistem, dan organ tanaman.

2) Model adalah benda tiruan dalam wujud tiga dimensi yang merupakan representasi atau pengganti dari benda yang sesungguhnya. Penggunaan model untuk mengatasi kendala tertentu sebagai pengganti realia. Misal untuk mempelajari sistem gerak, pencernaan, pernafasan, peredaran darah, sistem ekskresi, dan syaraf pada hewan.

3) Media grafis tergolong media visual yang menyalurkan pesan melalui simbol-simbol visual. Fungsi dari media grafis adalah menarik perhatian, memperjelas sajian pelajaran, dan mengilustrasikan suatu fakta atau konsep yang mudah terlupakan jika hanya dilakukan melalui penjelasan verbal.

Jenis-jenis media grafis adalah:

a) Gambar / foto: paling umum digunakan

b) Sketsa: gambar sederhana atau draft kasar yang melukiskan bagian pokok tanpa detail. Dengan sketsa dapat menarik perhatian siswa, menghindarkan verbalisme, dan memperjelas pesan.

c) Diagram / skema: gambar sederhana yang menggunakan garis dan simbol untuk menggambarkan struktur dari obyek tertentu secara garis besar. Misal untuk mempelajari organisasi kehidupan dari sel samapai organisme.

d) Bagan / chart : menyajikan ide atau konsep yang sulit sehingga lebih mudah dicerna siswa. Selain itu bagan mampu memberikan ringkasan butir-butir penting dari penyajian. Dalam bagan sering dijumpai bentuk grafis lain, seperti: gambar, diagram, kartun, atau lambang verbal. 
e) Grafik: gambar sederhana yang menggunakan garis, titik, simbol verbal atau bentuk tertentu yang menggambarkan data kuantitatif. Misal untuk mempelajari pertumbuhan.

b) Media proyeksi

1) Transparansi OHP merupakan alat bantu mengajar tatap muka sejati, sebab tata letak ruang kelas tetap seperti biasa, guru dapat bertatap muka dengan siswa (tanpa harus membelakangi siswa). Perangkat media transparansi meliputi perangkat lunak (Overhead transparancy / OHT) dan perangkat keras (Overhead projector / OHP). Teknik pembuatan media transparansi, yaitu: (a) Mengambil dari bahan cetak dengan teknik tertentu, (b) Membuat sendiri secara manual

2) Film bingkai / slide adalah film transparan yang umumnya berukuran $35 \mathrm{~mm}$ dan diberi bingkai 2X2 inci. Dalam satu paket berisi beberapa film bingkai yang terpisah satu sama lain. Manfaat film bingkai hampir sama dengan transparansi OHP, hanya kualitas visual yang dihasilkan lebih bagus. Sedangkan kelemahannya adalah beaya produksi dan peralatan lebih mahal serta kurang praktis. Untuk menyajikan dibutuhkan proyektor slide.

\section{Media Audio}

a) Radio

Radio merupakan perlengkapan elektronik yang dapat digunakan untuk mendengarkan berita yang bagus dan aktual, dapat mengetahui beberapa kejadian dan peristiwa-peristiwa penting dan baru, masalah-masalah kehidupan dan sebagainya. Radio dapat digunakan sebagai media pembelajaran yang cukup efektif.

b) Kaset-audio

Yang dibahas disini khusus kaset audio yang sering digunakan di sekolah. Keuntungannya adalah merupakan media yang ekonomis karena biaya pengadaan dan perawatan murah. 


\section{Media Audio-Visual}

a) Media video; Merupakan salah satu jenis media audio visual, selain film. Yang banyak dikembangkan untuk keperluan pembelajaran, biasa dikemas dalam bentuk VCD.

b) Media komputer; Media ini memiliki semua kelebihan yang dimiliki oleh media lain. Selain mampu menampilkan teks, gerak, suara dan gambar, komputer juga dapat digunakan secara interaktif, bukan hanya searah. Bahkan komputer yang disambung dengan internet dapat memberikan keleluasaan belajar menembus ruang dan waktu serta menyediakan sumber belajar yang hampir tanpa batas

\section{E. PEMETAAN ANTARA SUMBER BELAJAR, MEDIA DAN ALAT PERAGA}

Berikut ini penulis mencoba mendiskusikan kembali pemikiran-pemikiran pokok mengenai ketiga konsep di atas baik antara sumber belajar, media pembelajaran maupun alat peraga.

\section{Sumber Belajar}

Suatu pandangan yang keliru jika sumber belajar berarti di luar apa yang dimiliki guru, atau siswa. Guru merupakan sumber belajar yang utama, yaitu dengan segala kemampuan, wawasan keilmuan, keterampilan dan pengetahuan yang luas, maka segala informasi pembelajaran dapat diperoleh dari guru tersebut. Siswa, siswa memiliki sejumlah variasi aktivitas belajar, pengalaman belajar, pengetahuan dan keterampilan, maka dalam konteks tertentu apa yang terdapat pada diri siswa apat dijadikan sebagai sumber belajar dalam mempelajari suatu pengalamanpengalaman belajar yang baru. Sumber belajar pada dasarnya banyak sekali baik yang terdapat di lingkungan kelas, sekolah, sekitar sekolah bahkan di masyarakat, keluarga, di pasar, kota,desa, hutan dan sebagainya. Yang perlu dipahami dalam hal ini adalah masalah pemanfaatannya yang akan tergantung kepada kreativitas dan budaya mengajar guru atau pendidika itu sendiri. Vernon S. Gerlach \& Donald P. Ely (1971) menegaskan pada 
awalnya terdapat jenis sumber belajar yaitu manusia, bahan, lingkungan, alat dan perlengkapan, serta aktivitas.

a) Manusia

Manusia dapat dijadikan sebagai sumber belajar, peranannya sebagai sumber belajar dapat dibagi ke dalam dua kelompok. Kelompok pertama adalah manusia atau orang yang sudah dipersiapkan khusus sebagai sumber belajar melalui pendidikan yang khusus pula, seperti guru, konselor, administrator pendidikan, tutor dan sebagainya. Kelompok Kedua yaitu manusia atau orang yang tidak dipersiapkan secara khusus untuk menjadi seorang nara sumber akan tetapi memiliki keahlian yang mempunyai kaitan erat dengan program pembelajaran yang akan disampaikan, misalnya dokter, penyuluh kesehatan, petani, polisi dan sebagainya.

b) Bahan

Bahan yang dimaksud adalah segala sesuatu yang membawa pesan/ informasi untuk pembelajaran. Baik pesan itu dikemas dalam bentuk buku paket, video, film, bola dunia, grafik, CD interaktif dan sebagainya. Kelompok ini biasany disebut dengan media pembelajaran. Demikian halnya dengan bahan ini, bahwa dalam penggunaannya untuk suatu proses pembelajaran dapat dibedakan menjadi du akelompok yaitu bahan yang didesain khusus untuk pembelajaran, dan ada juga bahan/media yang dimanfaatkan untuk memberikan penjelasan materi pembelajaran yang relevan.

c) Lingkungan

Lingkungan yang dimaksud adalah lingkungan yang mampu memberikan pengkondisian belajar. Lingkungan ini juga di bagi dua kelompok yaitu lingkungan yang didesain khusus untuk pembelajaran, seperti laboratorium, kelas dan sejenisnya. Sedangkan lingkungan yang dimanfaatkan untuk mendukung keberhasilan penyampaian materi pembelajaran, 
di antaranyai lingkungan museum, kebun binatang dan sejenisnya.

d) Alat dan perlengkapan

Sumber belajar dalam bentuk alat atau perlengkapan adalah alat dan perlengkapan yang dimanfaatkan untuk produksi atau menampilkan sumber-sumber belajar lainnya. Seperti TV untuk membuat program belajar jarak jauh, komputer untuk membuat pembelajaran berbasis komputer, tape recorder untuk membuat program pembelajaran audio dalam pelajaran bahasa Inggris, terutama untuk menyampaikan informasi pembelajaran mengenai listening (mendengarkan), dan sejenisnya.

e) Aktivitas

Biasanya aktivitas yang dapat diajdikan sumber belajar adalah aktivitas yang mendukung pencapaian tujuan pembelajaran, di mana didalamnya terdapat perpaduan antara teknik penyajian dengan sumber belajar lainnya yang memudahkan siswa belajar. Seperti aktivitas dalam bentuk diskusi, mengamati, belajar tutorial, dan sejenisnya.

\section{Media Pembelajaran}

Dalam media pembelajaran terdapat dua unsur yang terkandung , yaitu (a) pesan atau bahan pengajaran yang akan disampaikan atau perangkat lunak, dan (b) alat penampil atau perangkat keras. Sebagai contoh guru akan mengajarkan bagaimana urutan gerakan melakukan sholat. Kemudian guru tersebut menuangkan ide-idenya dalam bentuk gambar ke dalam selembar kertas, ia menggambarkan setiap gerakan sholat tersebut dalam kertas tersebut, saat di kelas ia menjelaskannya kepada siswa bagaimana gerakan sholat tersebut dengan cara memperlihatkan poster yang bergambarkan gerakan-gerakan yang telah ia buat sebelumnya. Kemudian siswapun melakukan gerakan sholati dengan apa yang terdapat dalam poster tersebut. Dalam perkembangan selanjutnya poster ini termasuk ke dalam media 
sederhana. Dalam perkembangannya dan pemanfaatannya media pembelajaran ini dapat dibagi berdasarkan jenisnya, daya liputnya, bahan pembuatannya, yaitu sebagai berikut :

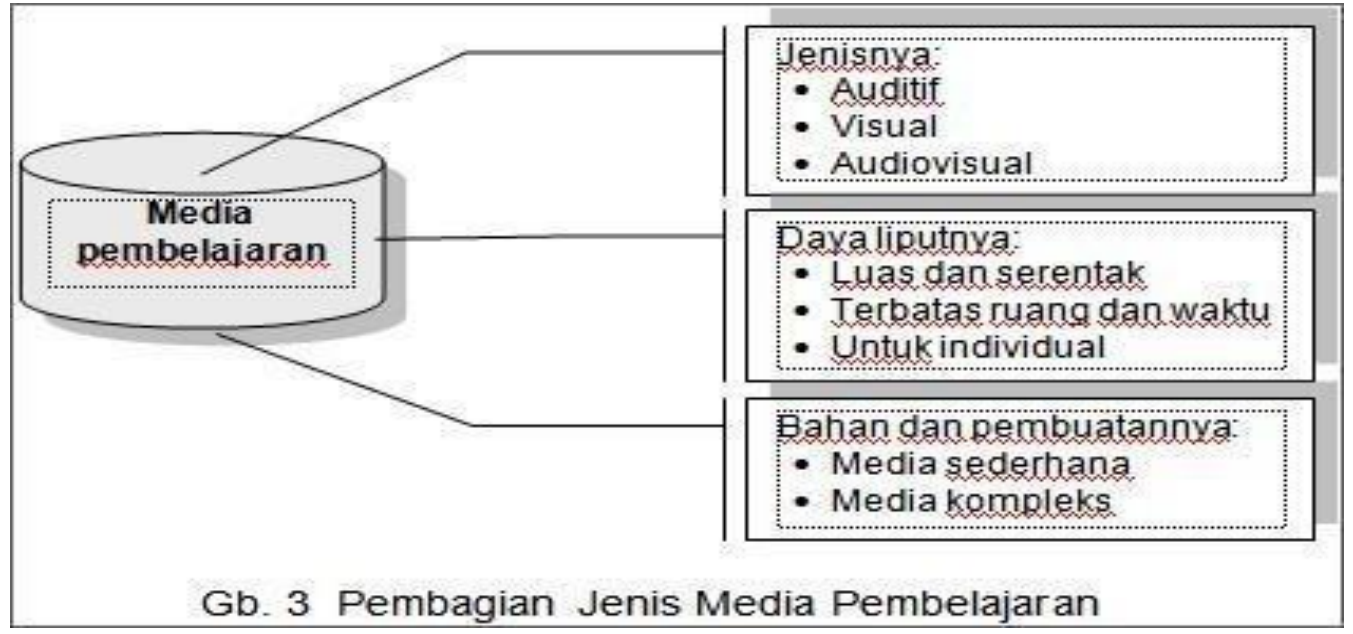

\section{Alat Peraga}

Kata kunci dalam memahami alat peraga dalam konteks pembelajaran adalah Nilai Manfaat, dalam arti segala sesuatu alat yang dapat menunjang keefektifan dan efesiensi penyampaian, pengembangan dan pemahaman informasi atau pesan pembelajaran. Ada istilah lain dari alat peraga ini, diantaranya sering disebut sebagai sarana belajar.

Sebagai ilustrasi, misalnya Pak Budi akan mengajarkan bagaimana gambar dalam televisi bisa terlihat di layar, maka Pak Budi membawa televisi ke kelas, kemudian ia membukanya di depan kelas, kemudian menjelaskan satu-persatu fungsi dari masing-masing komponen televisi tersebut kepada siswa sehingga siswa memahami kenapa gambar terlihat pad alayar televisi. Dalam ilustrasi tersebut kedudukan televisi adalah sebagai alat peraga, bukan sebagai media.

\section{F. PEMILIHAN DAN PEMBERDAYAAN SUMBER BELAJAR, MEDIA DAN ALAT PERAGA}

Agar sumber belajar, media dan alat peraga yang digunakan dalam proses pembelajaran dapat mendukung pencapaian kualitas pembelajaran, maka perlu diketahui beberapa patokan, acuan, kriteria atau prinsip masing-masing. Demikian juga dalam melakukan 
pemberdayaannya maka seorang guru harus memperhitungkan aspekaspek yang mendukungnya dalam Pemilihan Sumber Belajar, Meida dan Alat Peraga antara lain;

\section{Pemilihan Sumber Belajar}

Dalam pemilihan sumber belajar tergantung kepada (a) motivasi;

(a) kemampuan guru dalam penggunaannya. Selanjutnya akan ditentukan berdasarkan : (a) Program Pengajaran, (b) Kondisi Lingkungan, (c) Karakteristik siswa dan (d) Karakteristik sumber belajar. Kelima hal tersebut harus menjadi patokan dalam memilih sumber belajar yang akan dimanfaatkan dalam proses pembelajaran.

\section{Pemilihan Media Pembelajaran}

Dalam pemilihan media pembelajaran harus dikaitkan dengan : (1) kompetensi dasar; (2) strategi pembelajaran; (3) sistem evaluasi yang digunakan. Prinsip Pemilihan media: a) Tujuan Pemilihan; b)karakteristik media; 3)alternatif pemilihan. Faktor yang perlu diperhatikan : 1) objektivitas; 2) program pengajaran; 3) Sasaran program (siswa); 4) situasi dan kondisi; 5) kualitas teknis; 6) keefektifan dan efesiensi penggunaan.

Kriteria Pemilihan, mencakup:

a) Topik menarik minat siswa.

b) Materi dalam media penting bagi siswa.

c) Relevan dengan kurikulum yang berlaku.

d) Apakah materinya autentik dan aktual.

e) Apakah fakta atau konsepnya benar.

f) Format sistematis dan logis.

g) Objektif orientasi kebutuhan siswa.

h) Narasi, gambar, efek, warna dan sebagainya memenuhi syarat kualitas.

i) Bahasa, simbol dan ilustrasi cukup komunikatif.

j) Sudah teruji daya dukungnya.

\section{Pemilihan Alat Peraga}


Terdapat kriteria yang perlu diperhatikan dalam pemilihan alat peraga untuk pembelajaran masa kini terutama jika melihat karakteristik KBK, yaitu mencakup:

a) kesesuaian alat pengajaran yang dipilih dengan materi pengajaran atau jenis kegiatan yang akan dilakukan oleh siswa;

b) kemudahan dalam memperoleh alatnya dan kemudian dalam perancangannya;

c) kemudahan dalam penggunaannya;

d) terjamin keamanan dalam penggunaannya;

e) kemampuan dana;

f) kemudahan dalam penyimpanan, pemeliharaan dan sebagainya.

\section{Pemberdayaan Sumber Belajar, Media dan Alat Peraga}

Dengan ketersediaan ataupun hasil produksi, maka penggunaan sumber belajar, media dna alat peraga tidak hanya dilakukan begitu saja dari waktu ke waktu. Untuk itu perlu upaya pihak guru, sekolah, siswa, orang tua, komiter sekolah dan dewan sekolah untuk melakukan upaya-upaya pemberdayaan kearah yang lebih optimal. Hal ini sangat penting agar penggunaannya tidak monoton.

Asep Herry (2002), mengemukakan beberapa contoh upaya pemberdayaan sumber belajar yang mudah, murah dan efektif terhadap pencapaian tujuan pembelajaran, diantaranya :

a) Barang Bekas (Babe), seperti bekas, bungkus rokok, korek api, kertas, kotak bungkus, dan sebagainya dapat dimanfaatkan dalam proses pembelajaran seperti dalam melakukan pembekalan keterampilan dalam menghias, menggunting, dan kerjasama.

b) Realitas (sekolah, rumah, pemukiman), misalnya akan efektif dalam memberikan pengalaman tentang perjalanan siswa dari rumah smapai ke sekolah. 
c) Benda yang mempunyai nilai khusus, dapat digunakan untuk menyampaikan materi tentang perilaku, sikap dan moral peserta didik yang nilai-nilainya diambil dari perlakukan mereka terhadap benda-benda terebut.

Pemberdayaan sumber belajar, media dan alat peraga dapat dilakukan pada tahapan : (a) diawal pembelajaran, (b) selama proses pembelajaran, (c) akhir proses pembelajaran, (d) di luar waktu pembelajaran. Dalam hubungannya dengan upaya memelihara sumber belajar, media dan alat peraga di sekolah, maka perlu dilakukan kerjasama antara, guru dengan Kepala Sekolah dan tenaga kependidikan lainnya, pengawas akademis, supervisor, orang tua, dewan sekolah, bahkan siswa itu sendiri.

Pada dasarnya uraian informasi pelatihan dalam makalah kecil ini semata-mata hanya merupakan rethinking (relaksasi pemikiran kembali) pada diri kita semua terhadap apa yang telah biasa dilakukan. Akan tetapi dari apa yang sudah didiskusikan akan mampu memberikan dorongan bagi kita semua untuk lebih mampu meningkatkan kualitas pembelajaran di era modern ini melalui penggunaan dan pemanfaatan sumber belajar, media dan alat peraga secara lebih tepat dan optimal. 


\section{BAB X \\ KURIKULUM PENDIDIKAN}

Kurikulum adalah perangkat mata pelajaran dan program pendidikan yang diberikan oleh suatu lembaga penyelenggara pendidikan yang berisi rancangan pelajaran yang akan diberikan kepada peserta pelajaran dalam satu periode jenjang pendidikan. Penyusunan perangkat mata pelajaran ini disesuaikan dengan keadaan dan kemampuan setiap jenjang pendidikan dalam penyelenggaraan pendidikan tersebut serta kebutuhan lapangan kerja.

Perubahan kurikulum dari waktu ke waktu bukan tanpa alasan dan landasan yang jelas, sebab perubahan ini disemangati oleh keinginan untuk terus memperbaiki, mengembangkan, dan meningkatkan kualitas sistem pendidikan nasional. Persekolahan sebagai ujung tombak dalam implementasi kurikulum dituntut untuk memahami dan mengaplikasikannya secara optimal dan penuh kesungguhan, sebab mutu penyelenggaraan proses pendidikan salah satunya dilihat dari hal tersebut. Namun di lapangan, perubahan kurikulum seringkali menimbulkan persoalan baru, sehingga pada tahap awal implementasinya memiliki kendala teknis. Sehingga sekolah sebagai penyelenggara proses pendidikan formal sedikit banyaknya pada tahap awal ini membutuhkan energi yang besar hanya untuk mengetahui dan memahami isi dan tujuan kurikulum baru. Dalam teknis pelaksanaannya pun sedikit terkendala disebabkan perlu adaptasi terhadap perubahan atas kurikulum terdahulu yang sudah biasa diterapkannya.

\section{A. PENGERTIAN KURIKULUM}

Pada awal mulanya istilah Kurikulum dalam dunia olah raga khususnya atletik pada zaman Yunani kuno. Curriculum berasal dari bahasa Yunani Curier atau kurir (dalam bahasa Indonesia) yang berarti seseorang yang bertugas menyampaikan sesuatu kepada orang lain di lain tempat. Kurikulum diartikan suatu jarak yang ditempuh oleh pelari. Tapi juga suatu chariot kereta pacu pada zaman dulu, 
suatu alat yang membawa seseorang dari tempat start ke tempat finish.

Secara terminologi, istilah kurikulum digunakan dalam dunia pendidikan, yaitu sejumlah pengetahuan atau kemampuan yang harus ditempuh atau diselesaikan siswa guna mencapai tingkatan tertentu secara formal dan dapat dipertanggung jawabkan. Adapun defenisi menurut para ahli tentang kurikulum sebagai berikut:

\section{Prof. Dr. S. Nasution, M. A.}

Menjelaskan kurikulum sebagai suatu rencana yang disusun untuk melancarkan proses kegiatan belajar mengajar di bawah naungan, bimbingan \& tanggunga jawab sekolah / lembaga pendidikan.

\section{Kerr, J. F (1968)}

Pengertian kurikulum ialah sebuah pembelajaran yang dirancang dan juga dilaksanakan dengan individu serta juga berkelompok baik itu di luar ataupun di dalam sekolah.

\section{Murray Print}

Pengertian kurikulum ialah sebuah ruang pembelajaran yang sudah terencana diberikan secara langsung kepada siswa oleh sebuah lembaga pendidikan dan juga pengalaman yang dapat dinikmati oleh semua siswa pada saat kurikulum tersebut diterapkan.

\section{UU. No. 20 Tahun 2003}

Pengertian kurikulum ialah suatu perangkat rencana dan juga pengaturan tentang tujuan, isi, dan juga bahan pengajaran dan cara yang digunakan ialah sebagai suatu pedoman didalam suatu penyelenggaraan kegiatan dalam pembelajaran untuk dapat mencapai suatu tujuan pendidikan nasional.

\section{Dr. H. Nana Sudjana Tahun (2005)}

Kurikulum merupakan niat \& harapan yang dituangkan kedalam bentuk rencana maupun program pendidikan yang dilaksanakan oleh para pendidik di sekolah. Kurikulum sebagai niat \& rencana, sedangkan pelaksaannya adalah proses belajar mengajar.

Dapat disimpulkan bahwa kurikulum merupakan suatu perangkat pendidikan yang menjadi jawaban terhadap berbagai kebutuhan dan 
tantangan di dalam masyarakat, atau Kurikulum dapat di artikan sebagai suatu perangkat mata pelajaran maupun program pendidikan yang memuat rancangan berbagai jenis pelajaran di sekolah. Dengan adanya kurikulum maka proses belajar-mengajar di sekolah dapat berjalan dengan baik dan teratur. Kurikulum tentunya wajib di terapkan di setiap sekolah yang ada di Indonesia sesuai dengan ketentuan dan kebijakan yang berlaku. Dengan adanya kurikulum maka aktivitas dalam belajar-mengajar yang dilakukan di sekolah mampu memenuhi standar pendidikan.

\section{B. KOMPONEN KURIKULUM}

Kurikulum merupakan suatu sistem yang memiliki komponen komponen tertentu. Sistem kurikulum terbentuk oleh empat komponen, yaitu : komponen tujuan, isi kurikulum, komponen metode atau strategi pencapaian tujuan, dan komponen evaluasi. Sebagai suatu sistem, setiap komponen harus saling berkaitan satu sama lain. Manakala salah satu komponen yang membentuk sistem kurikulum terganggu atau tidak berkaitan dengan komponen lainnya, maka sistem kurikulum secara keseluruhan juga akan tergganggu.

\section{Komponen Tujuan}

Komponen tujuan berhubungan dengan arah atau hasil yang diharapkan. Dalam skala makro, rumusan tujuan kurikulum erat kaitannya dengan filsafat atau sistem nilai yang dianut masyarakat. Bahkan, rumusan tujuan yang menggambarkan suatu masyarakat yang di cita - citakan, misalkan, filsafat atau sistem nilai yang dianut masyarakat Indonesia adalah pancasila, maka tujuan yang diharapkan tercapai oleh suatu kurikulum adalah terbentuknya masyarakat yang pancasilais. Dalam skala mikro, tujuan kurikulum berhubungan dengan misi dan visi sekolah serta tujuan yang lebih sempit, seperti tujuan setiap mata pelajaran dan tujuan proses pembelajaran.

\section{Komponen Isi/ Materi Pelajaran}

Isi kurikulum merupakan komponen yang berhubungan dengan pengalaman belajar yang harus dimiliki siswa. Isi kurikulum itu 
menyangkut semua aspek baik yang berhubungan dengan pengetahuan atau materi pelajaran yang biasanya tergambarkan pada isi setiap materi pelajaran yang diberikan maupun aktivitas dan kegiatan siswa. Baik materi maupun aktivitas itu seluruhnya diarahkan untuk mencapai tujuan yang ditentukan.

\section{Komponen Metode/ Strategi}

Strategi dan metode merupakan komponen ketiga dalam pengembangan kurikulum. Komponen ini merupakan komponen yang memiliki peran yang sangat penting, sebab berhubungan dengan implementasi kurikulum. Bagaimana bagus dan idealnya tujuan yang harus dicapai tanpa strategi yang tepat untuk mencapainya, maka maka tujuan itu tidak mungkin dapat tercapai. Strategi meliputi rencana, metode dan perangkat kegiatan yang direncanakan untuk mencapai tujuan tertentu. Sejalan dengan pendapat diatas, T. Rajakoni mengartikan strategi pembelajaran sebagai pola dan urutan umum perbuatan guru-siswa dalam mewujudkan kegiatan belajar mengajar untuk mencapai tujuan yang telah ditentukan.

Dari kedua pengertian diatas, ada dua hal yang patut kita cermati. Pertama, strategi pembelajaran merupakan rencana tindakan (rangkaian kegiatan) termasuk penggunaan metode dan pemanfaatan berbagai sumber daya/kekuatan dalam pembelajaran. Ini berarti penyusunan atau strategi baru sampai pada proses penyusunan rencana kerja, belum sampai pada tindakan. Kedua, strategi disusun untuk mencapai tujuan tertentu. artinya, arah dari semua keputusan penyusunan strategi adalah pencapaian tujuan.

Upaya untuk mengimplementasikan rencana yang sudah disusun dalam kegiatan nyata agar tujuan yang telah disusun tercapai secara optimal, dinamakan metode. Ini berarti metode digunakan untuk merealisasikan strategi yang telah ditetapkan. Dengan demikian, bisa jadi satu strategi pembelajaran digunakan beberapa metode. Misalnya untuk melaksanakan strategi ekspositori bisa digunakan metode ceramah sekaligus metode tanya jawab atau bahkan diskusi 
dengan pemanfaatan sumber daya yang tersedia termasuk menggunakan media pembelajaran. Oleh karena itu, strategi berbeda dengan metode. Strategi menunjuk pada a plan of operation achieving something, sedangkan metode adalah a way in achieving something.

\section{Komponen Evaluasi}

Evaluasi merupakan bagian yang tak terpisahkan dari kurikulum. Melalui evaluasi, dapat ditentukan nilai dan arti kurikulum sehingga dapat dijadikan bahan pertimbangan apakah suatu kurikulum perlu dipertahankan atau tidak, dan bagian bagian mana yang harus disempurnakan. Evaluasi merupakan komponen untuk melihat efektivitas pencapaian tujuan. Dalam konteks kurikulum, evaluasi dapat berfungsi untuk mengetahui apakah tujuan yang telah ditetapkan telah tercapai atau belum, atau evaluasi digunakan sebagai umpan balik dalam perbaikan strategi yang ditetapkan. Kedua fungsi tersebut menurut Scriven (1967) adalah evaluasi sebagai fungsi sumatif dan evaluasi sebagai fungsi formatif. Evaluasi sebagai alat untuk melihat keberhasilan pencapaian tujuan dapat dikelompokkan kedalam dua jenis, yaitu tes dan nontes.

\section{PRINSIP KURIKULUM}

Sejumlah prinsip yang dianggap penting dan menjadi pedoman pada saat ini pada umumnya.

\section{Prinsip Relevansi}

Kurikulum merupakan rel-nya pendidikan untuk membawa siswa agar dapat hidup sesuai dengan nilai-nilai yang ada di masyarakat serta membekali siswa baik dalam bidang pengetahuan, sikap maupun keterampilan sesuai dengan tuntutan dan harapa masyarakat. Oleh sebab itu, pengalaman-pengalaman belajar yang disusun dalam kurikulum harus relevan dengan kebutuhan masyarakat. 


\section{a) Relevansi Internal}

Relevansi internal adalah bahwa setiap kurikulum harus memiliki keserasian antara komponen-komponennya, yaitu keserasian yang harus dicapai, isi, materi atau pengalaman belajar yang harus dimiliki siswa, strategi atau metode yang digunakan serta alat penilaian untuk melihat ketercapaian tujuan. Relevansi ini menunjukkan keutuhan suatu kurikulum.

\section{b) Relevansi Eksternal}

Relevansi Eksternal, berkaitan dengan keserasian antara tujuan, isi dan proses belajar siswa yang tercakup dalam kurikulum dengan kebutuhan dan tuntutan masyarakat. Ada tiga macam relevansi eksternal yaitu :

1) Relevan dengan lingkungan hidup peserta didik. Artinya, bahwa proses pengembangan dan penetapan isi kurikulum hendaknya disesuaikan dengan kondisi lingkungan sekitar siswa. Contohnya untuk siswa yang ada di perkotaan perlu diperkenalkan kehidupan di lingkungan kota, seperti keramaian dan rambu-rambu lalu lintas, tata cara dan pelayan jasa bank, kantor pos dsb. Begitu juga untuk sekolah yang berada di lingkungan pantai, seperti mengenai tambak, kehidupan nelayan, koperasi, pembibitan udang, dsb.

2) Relevan dengan perkembangan zaman baik sekarang maupun dengan yang akan datang. Artinya, isi kurikulum harus sesuai dengan situasi dan kondisi yang sedang berkembang. Selain itu juga apa yang diajarkan kepada siswa harus bermanfaat untuk kehidupan siswa pada waktu yang akan datang. Misalkan untuk kehidupan yang akan datang, penggunaan computer dan internet menjadi salah satu kebutuhan, maka dengan demikian bagaimana cara memanfaatkan computer dan bagaimana cara mendapatkan informasi dari internet sudah harus diperkenalkan kepada siswa. Demikian juga dengan kemapuan berbahasa. Pada masa yang akan datang ketika pasar bebas seperti persetujuan APEC mulai berlaku, maka masyarakat akan 
dihadapkan kepada persaingan merebut pasar kerja dengan orang-orang asing. Oleh karenanya keterampilan berbahasa asing sudah harus mulai dipupuk sejak sekarang.

3) Relevan dengan tuntutan dunia pekerjaan. Artinya, bahwa apa yang diajarkan di sekolah harus mampu memenuhi dunia kerja. Untuk sekolah kejuruan contohnya, kalau dahulu di Sekolah Kejuruan Ekonomi dilatih bagaimana agar siswa mampu menggunakan mesin tik sudah tidak banyak digunakan, akan tetapi yang lebih banyak digunakan computer. Dengan demikian, keterampilan mengoperasikan computer harus diajarkan. Demikian jugahalnya dengan tuntutan dunia kerja kepariwisataan, perbankan, asuransi, perhotelan $\mathrm{dsb}$, isi kurikulum harus menyesuaikan dengan tuntutan pekerjaan pekerjaan di setiap bidang.

\section{Prinsip Fleksibilitas}

Apa yang diharapkan dalam kurikulum ideal kadan-kadang tidak sesuai dengan kondisi kenyataanyang ada. Bisa saja ketiksesuaian itu ditunjukkan oleh kemampuan guru yang kurang,latar belakang atau kemampuan dasar siswa yang rendah, atau mungkin sarana dan prasarana yang ada di sekolah tidak memadai. Maka kurikulum harus bersifat lentur dan fleksibel. Artinya, kurikulum itu harus bisa dilaksanakan sesuai dengan kondisi yang ada. Kurikulum yang kaku atau tidak fleksibel akan sulit diterapkan. Prinsip fleksibilitas memiliki dua sisi :

a) Fleksibel bagi guru, artinya kurikulum harus memberikan ruang gerak bagu guru untuk mengembangkan program pengajarannya sesuai dengan kondisi yang ada.

b) Fleksibel bagi siswa, artinya kurikulum harus menyediakan berbagai kemungkinan program pilihan sesuai dengan bakat dan minat siswa.

\section{Prinsip Kontinuitas}

Prinsip ini mengandung pengertian bahwa perlu dijaga saling keterkaitan dan kesinambungan antara materi pelajaran pada berbagai 
jenjang dan jenis program pendidikan. Dalam penyusunan materi pelajaran

\section{Efektifitas}

Prinsip efektifitas berkenaan dengan rencana dalam suatu kurikulum dapat dilaksanakan dan dapat dicapai dalam kegiatan belajar mengajar. Terdapat dua sisi efektifitas dalam suatu pengembangan kurikulum yaitu :

a) Efektifitas berhubungan dengan kegiatan guru dalam melaksanakan tugas mengimplementasikan kurikulum di dalam kelas. Contoh, apabila guru menetapkan dalam satu senmester harus menyelesaikan 12 program pembelajaran sesuai dengan pedoman kurikulum, ternyata dalam jangka waktu tersebut hanya dapat menyelesaikan 4 atau 5 program saja, berarti dapat dikatakan bahwa pelaksanaan program itu tidak efektif.

b) Efektifitas kegiatan siswa dalam melaksanakan kegiatan belajar. Maksudnya sejauh mana siswa dapat mencapai tujuan yang telah ditentukan sesuai dengan jangka waktu tertentu. Contoh, apabila ditetapkan dalam satu semester siswa harus dapat mencapai sejumlah tujuan pembelajaran, ternyata hanya sebagian saja dapat dicapai siswa, maka dapat dikatakan bahwa proses pembelejaran siswa tidak efektif.

\section{Efisiensi}

Prinsip efisiensi berhubungan dengan pernbandingan antara tenaga, waktu, suara, dan biaya yang dikeluarkan dengan hasil yang diperoleh. Kurikulum dikatakan memiliki tingkat efisiensi yang tinggi apabila dengan sarana, biaya yang minimal dan waktu yang terbatas dapat memperoleh hasil yang maksimal. Betapa pun bagus dan idealnya suatu kurikulum, manakala menuntut peralatan, sarana dan prasarana yang sangat khusus serta mahal pula harganya, maka kurikulum itu tidak praktis dan sukar untuk dilaksanakan. Kurikulum harus dirancang untuk dapat digunakan dalam segala keterbatasan. Pengembangan kurikulum sekolah di Indonesia mengikuti prinsipprinsip pengembangan kurikulum yang berbeda, namun sasaran yang 
hendak dicapai adalah sama, yaitu dalam rangka mewujudkan citacita pembangunan nasional pada umumnya dan tujuan pendidikan nasional pada khususnya dengan berdasarkan Pancasila dan UUD 1945.

\section{FUNGSI KURIKULUM}

Secara umum fungsi kurikulum adalah sebagai alat untuk membantu peserta didik untuk mengembangkan pribadinya ke arah tujuan pendidikan. Kurikulum itu segala aspek yang mempengaruhi peserta didik di sekolah, termasuk guru dan sarana serta prasarana lainnya. Kurikulum sebagai program belajar bagi siswa, disusun secara sistematis dan logis, diberikan oleh sekolah untuk mencapai tujuan pendidikan. Sebagai program belajar, kurikulum adalah niat, rencana dan harapan.Menurut Alexander Inglis, fungsi kurikulum meliputi :

1. Fungsi Penyesuaian, karena individu hidup dalam lingkungan, sedangkan lingkungan tersebut senantiasa berubah dan dinamis, maka setiap individu harus mampu menyesuaikan diri secara dinamis. Dan di balik lingkungan pun harus disesuaikan dengan kondisi perorangan, disinilah letak fungsi kurikulum sebagai alat pendidikan menuju individu yang well adjusted.

2. Fungsi Integrasi, kurikulum berfungsi mendidik pribadi-pribadi yang terintegrasi. Oleh karena individu itu sendiri merupakan bagian integral dari masyarakat, maka pribadi yang terintegrasi itu akan memberikan sumbangan dalam rangka pembentukan atau pengintegrasian masyarakat.

3. Fungsi Deferensiasi, kurikulum perlu memberikan pelayanan terhadap perbedaan- perbedaan perorangan dalam masyarakat. Pada dasarnya deferensiasi akan mendorong orang berpikir kritis dankreatif, dan ini akan mendorong kemajuan sosial dalam masyarakat.

4. Fungsi Persiapan, kurikulum berfungsi mempersiapkan siswa agar mampu melanjutkan studi lebih lanjut untuk jangkauan yang lebih jauh atau terjun ke masyarakat. Mempersiapkan kemampuan 
sangat perlu, karena sekolah tidak mungkin memberikan semua apa yang diperlukan atau semua apa yang menarik minat mereka.

5. Fungsi Pemilihan, antara keperbedaan dan pemilihan mempunyai hubungan yang erat.Pengakuan atas perbedaan berarti pula diberikan kesempatan bagi seseorang untuk memilih apa yang dinginkan dan menarik minatnya. Ini merupakan kebutuhan yang sangat ideal bagi masyarakat yang demokratis, sehingga kurikulum perlu diprogram secara fleksibel.

6. Fungsi Diagnostik, salah satu segi pelayanan pendidikan adalah membantu dan mengarahkan para siswa agar mereka mampu memahami dan menerima dirinya sehingga dapat mengembangkan semua potensi yang dimiliki.Ini dapat dilakukan bila mereka menyadari semua kelemahan dan kekuatan yang dimiliki melalui eksplorasi dan prognosa. Fungsi kurikulum dalam mendiagnosa dan membimbing siswa agar dapat mengembangkan potensi siswa secara optimal.

Sedangkan fungsi praksis dari kurikulum adalah meliputi :

1. Fungsi bagi sekolah yang bersangkutan yakni sebagai alat untuk mencapai tujuan-tujuan pendidikan yang diinginkan dan sebagai pedoman dalam mengatur kegiatan pendidikan sehari-hari.

2. Fungsi bagi sekolah yang diatasnya adalah untuk menjamin adanya pemeliharaan keseimbangan proses pendidikan.

3. Fungsi bagi masyarakat dan pemakai lulusan.

\section{E. PERANAN KURIKULUM}

Kurikulum bagi program pendidikan dimana sekolah sebagai institusi social melaksanakan oprerasinya, paling tidak dapat ditentukan 3 jenis kurikulum :

1. Peranan Konservatif Menekankan bahwa kurikulum itu dapat dijadikan sebagai sarana untuk mentramisikan nilai-nilai warisan budaya masa lalu yang dianggap masih relevan dengan masa kini bagi generasi muda.

2. Peranan Kritis dan evaluative Perkembangan ilmu pengetahuan dan aspek-aspek lainnya senantiasa terjadi setiap saat. Peranan 
kreatif menekankan bahwa kurikulum harus mampu mengembangkan sesuatu yang baru sesuai dengan perkembangan.

3. Peranan Aktif Peranan ini dilatar belakangi oleh adanya kenyataan bahwa nilai-nilai dan budaya yang hidup dalam masyarakat senantiasa mengalami perubahan. Sehingga pewarisan dan nilai-nilai budaya masa lalu.kepada siswa perlu disesuaikan dengan masa sekarang.

\section{F. MACAM-MACAM KURIKULUM}

Ditinjau dari konsep dan pelaksanaannya, kita mengenal beberapa istilah kurikulum sebagai berikut:

1. Kurikulum ideal yaitu kurikulum yang berisi sesuatu yang ideal, sesuatu yang dicita-citakan sebagaimana yang tertuang di dalam dokumen kurikulum.

2. Kurikulum aktual yaitu kurikulum yang dilaksanakan dalam proses pengajaran dan pembelajaran. Kenyataan pada umumnya memang jauh berbeda dengan harapan. Namun demikian, kurikulum aktual seharusnya mendekati dengan kurikulum ideal. Kurikulum dan pengajaran merupakan dua istilah yang tidak dapat dipisahkan. Kurikulum merujuk kepada bahan ajar yang telah direncanakan yang akan dilaksanakan dalam jangka panjang. Sedang pengajaran merujuk kepada pelaksanaan kurikulum tersebut secara bertahap dalam belajar mengajar.

3. Kurikulum tersembunyi (hidden curriculum) yaitu segala sesuatu yang terjadi pada saat pelaksanaan kurikulum ideal menjadi kurikulum faktual. Segala sesuatu itu bisa berupa pengaruh guru, kepala sekolah, tenaga administrasi, atau bahkan dari peserta didik itu sendiri. Kebiasaan guru datang tepat waktu ketika mengajar di kelas, sebagai contoh, akan menjadi kurikulum tersembunyi yang akan berpengaruh kepada pembentukan kepribadian peserta didik. Berdasarkan struktur dan materi mata pelajaran yang diajarkan, kita dapat membedakan: 


\section{Kurikulum terpisah-pisah (separated curriculum);}

Kurikulum ini menyajikan segala bahan pelajaran dalam berbagai macam mata pelajaran yang terpisah-pisah satu sama lain, seakan-akan ada batas pemisah antara mata pelajaran satu dengan yang lain, juga antara kelas yang satu dengan kelas yang lain. Beberapa hal positif dari separated curriculum ini adalah : Bahan pelajaran disajikan secara sistematis dan logis dapat dilaksanakan untuk mewariskan nilai-nilai budaya terdahulu. Kurikulum ini mudah diubah dan dikembangkan. Bentuk kurikulum ini mudah dipola, dibentuk, didesain bahkan mudah untuk diperluas dan dipersempit sehingga mudah disesuaikan dengan waktu yang ada. Sedangkan beberapa kritik terhadap kurikulum ini antara lain: Mata pelajaran terlepas-lepas satu sama lain. Tidak atau kurang memperhatikan masalah yang dihadapi dalam kehidupan sehari-hari. Dari sudut psikologis, kurikulum demikian mengandung kelemahan: banyak terjadi verbalitas dan menghafal serta makna tujuan pelajaran kurang dihayati oleh anak didik. Kurikulum ini cenderung statis dan ketinggalan dari perkembangan zaman

\section{Kurikulum terpadu (integrated curriculum); Dalam}

kurikulum terpadu atau terintergrasi, batas-batas diantara mata pelajaran sudah tidak terlihat sama sekali, karena semua mata pelajaran sudah dirumuskan dalam bentuk masalah atau unit. Ciri-ciri kurikulum terintegrasi ini antara lain: Berdasarkan filsafat pendidikan demokrasi, berdasarkan psikologi belajar gestalt dan organismik, berdasarkan landasan sosiologis dan sosiokultural, berdasarkan kebutuhan, minat dan tingkat perkembangan atau pertumbuhan siswa. Bentuk kurikulum ini tidak hanya ditunjang oleh semua mata pelajaran atau bidang studi yang ada, tetapi lebih luas. Bahkan mata pelajaran baru dapat saja muncul dan dimanfaatkan guna pemecahan masalah. Sistem penyampaian menggunakan sistem pengajaran unit, baik pengalaman (experience) atau pelajaran (subject matter unit). 
Peran guru sama aktifnya dengan peran murid. Guru selaku pembimbing.

6. Kurikulum terkorelasi (corelated curriculum); Yaitu kurikulum yang menekankan perlunya hubungan diantara dua atau lebih mata pelajaran tanpa menghilangkan batas-batas setiap mata pelajaran. Misalnya Sejarah dan Ilmu Bumi dapat diajarkan untuk saling memperkuat.Ada tiga jenis korelasi yang sifatnya bergantung dari jenis mata pelajaran. Korelasi faktual, misalnya sejarah dan kesusastraan. Fakta-fakta sejarah disajikan melalui penulisan karangan sehingga menambah kemungkinan menikmati bacaannya oleh siswa. Korelasi deskriptif, korelasi ini dapat dilihat pada penggunaan generalisasi yang berlaku untuk dua atau lebih mata pelajaran. Misal psikologi dapat berkorelasi dengan sejarah atau Ilmu Pengetahuan Sosial dengan menggunakan prinsip-prinsip yang ada dalam psikologi untuk menerangkan kejadian-kejadian sosial. Korelasi normatif, hampir sama denagan korelasi deskriptif, perbedaannya terletak pada prinsipnya yang bersifat moral sosial. Sejarah dan kesusastraan dapat dikorelasikan berdasarkan prinsip-prinsip moral sosial dan etika. Berdasarkan pengembangnya dan penggunaannya, kurikulum dapat dibedakan menjadi:

a) Kurikulum nasional (national curriculum); yakni kurikulum yang disusun oleh tim pengembang tingkat nasional dan digunakan secara nasional.

b) Kurikulum negara bagian (state curriculum): yakni kurikulum yang disusun oleh masing-masing negara bagian, misalnya di masing-masing negara bagian di Amerika Serikat.

c) Kurikulum sekolah (school curriculum); yakni kurikulum yang disusun oleh satuan pendidikan sekolah. Kurikulum Tingkat Satuan Pendidikan (KTSP) merupakan kurikulum sekolah. Kurikulum sekolah lahir dari keinginan untuk melakukan diferensiasi dalam kurikulum. 


\section{G. TUJUAN KURIKULUM}

Tujuan kurikulum pada dasarnya merupakan tujuan setiap program pendidikan yang diberikan kepada anak didik, Karena kurikulum merupakan alat antuk mencapai tujuan, maka kurikulum harus dijabarkan dari tujuan umum pendidikan. Dalam sistem pendidikan di Indonesia tujuan pendidikan bersumber kepada falsafah Bangsa Indonesia. Di Indonesia ada 4 tujuan utama yang secara hirarki sebagai baerikut:

\section{Tujuan Nasional}

Dalam Undang-undang No. 2 tahun 1980 tentang sistem Pendidikan Nasional rumusan tujuan pendidikan nasional disebutkan Pendidikan Nasional bertujuan mencerdaskan kehidupan bangsa dan mengembangkan manusia indonesia seutuhnya yaitu manusia yang beriman dan bertaqwa terhadap Tuhan Yang Maha Esa dan berbudi pekerti luhur, memiliki pengetahuan dan keterampilan. Kesehatan asmani dan rohani, kepribadian yang mantap dan mandiri serta rasa tariggung jawab kemasyarakatan dan kebangsaan. Dari tujuan nasional kemudian dijabarkan ke dalam tujuan insitusional/ lembaga, tujuan kurikuler, sampai kepada tujuan insfruksional dengan penjabaran sebagai berikut:

\section{Tujuan Intitusional}

Tujuan institusional adalah tujuan yang harus dicapai oleh suatu lembaga pendidikan, umpamanya MI. MTs, MA, SD, SMP, SMA, dan sebagainya. Artinya apa yang harus dimiliki anak didik setelah menamatkan lembaga pendidikan tersebut, Sebagai contoh, kemampuan apa yang harus dimiliki anak didik setelah menamatkan lembaga pendidikan iersebut. Sebagai contoh, kemampuan apa yang diharapkan dimiliki oleh anak yang tamat MI, MTs, atau Madrasah Aliyah. Rumusan tujuan institusional harus merupakan penjabaran dan tujuan umum (riasional), harus memiliki kesinambungan antara satu jenjang pendidikan tinggi dengan jenjang Iainnya (MI, MTs, dan MA sampal ke IAIN/ 
perguruan tinggi). Tujuan institusional juga harus memperhatikan fungsi dan karakter dari lembaga pendidikannya, seperti lembaga pendidikan umum, pendidikan guru dan sebagainya.

\section{Tujuan Kurikuler}

Tujuan kurikuler adalah penjabaran dan tujuan kelembagaan pendidikan (tujuan institusiorial). Tujuan kurikuler adalah tujuan di bidang studi atau mata pelajaran sehingga mencerminkan hakikat keilmuan yang ada di dalamnya. Secara oerasional adalah rumusan kemampuan yang diharapkan dapat dimiliki anak didik setelah mempelajari suatu mata pelajaran atau bidang studi tersebut.

\section{Tujuan Instruksional}

Tujuan instruksional dijabarkan dari tujuan kurikuler. Tujuan ini adalah tujuan yang langsung dihadapkan kepada anak didik sebab hrus dicapai oIeh mereka setelah menempuh proses belajar-mengajar. Oleh karena itu tujuan instruksional dirumuskan sebagai kemampuan-kemampuan yang diharapkan dapat dimiliki oleh anak didik setelah mereka menyelesaikan proses belajar-mengajar. Ada dua jenis tujuan institusional, yaitu tujuan instruksional umum (TIU) dan tujuan instruksional khusus (TIK). Perbedaan kedua tujuan tersebut terletak dalam hal kemampuan yang diharapkan dikuasai anak didik. Pada TIU sifatnya lebih luas dan mendalam, sedangkan TIK lebih terbatas dan harus dapat diukur pada saat berlangsungnya proses belajarmengajar. Dengan demikian TIK harus lebih operasional dan mudah dilakukan pengukuran.

Meskipun banyak definisi kurikulum yang satu dengan yang lain saling berbeda, dikarenakan dasar filsafat yang dianut oleh para penulis berbeda-beda. Walaupun demikian ada kesamaan satu fungsi, yaitu bahwa kurikulum adalah alat untuk mencapai tujuan pendidikan. Kurikulum mengandung sekian banyak unsur konstruktif supaya pembelajaran berjalan dengan optimal. Sejumlah pakar kurikulum 
berpendapat bahwa jantung pendidikan berada pada kurikulum. Baik dan buruknya hasil pendidikan ditentukan oleh kurikulum, apakah mampu membangun kesadaran kritis terhadap peserta didik ataukah tidak. Dengan demikian, kurikulum memegang peran penting bagi keberhasilan sebuah pendidikan dan bagi peserta didik.

\section{H. MANFAAT KURIKULUM}

Dari penjelasan di atas dapat diambil kesimpulan beberapa manfaat dari kurikulum diantaranya seperti:

1. Manfaat bagi guru

a) Dapat menjadi pedoman untuk merancang, melaksanakan dan mengevaluasi hasil kegiatan pembelajaran.

b) Dapat memberikan pemahaman kepada pengajar atau guru dalam menjalankan tugasnya.

c) Dapat mendorong untuk lebih kreatif dalam penyelenggaraan program pendidikan.

d) Dapat membantu dalam menunjang pengajaran supaya lebih baik.

2. Manfaat bagi sekolah

a) Dapat mendorong sekolah untuk menyukseskan penyelenggaraan pendidikan KTSP (Kurikulum Tingkat Satuan Pendidikan).

b) Dapat memberikan peluang bagi sekolah plus untuk mengembangkan kurikulum yang sesuai dengan kebutuhan.

c) Sebagai alat untuk mencapai tujuan program pendidikan.

3. Manfaat bagi Masyarakat

a) Dapat menjadi acuan standar bagi orang tua untuk ikut serta dalam membimbing anaknya dalam belajar.

b) Dengan kurikulum, masyarakat dapat ikut berpartisipasi dalam rangka mengembangkan program pendidikan melalui kritik dan juga saran yang membangun yang menyempurnakan program pendidikan. 


\section{BAB XI \\ KONDISI MASALAH BELAJAR DAN PEMBELAJARAN}

Dalam masalah-masalah belajar dalam pembelajaran pada siswa-guru atau calon guru harus dapat memahami bahwa kondisi lingkungan siswa juga dapat menjadi sumber timbulnya masalahmasalah belajar. Guru atau calon guru dapat memotivasi belajar siswa dengan menjadi tenaga pendorong bagi siswa untuk mendayagunakan potensi-potensi yang ada pada dirinya dan potensi di luar dirinya untuk mewujudkan tujuan belajar dan hasil belajar yang diharapkan.

\section{A. PENGERTIAN MASALAH}

Masalah adalah sesuatu yang tidak disukai adanya, menimbulkan masalah bagi diri sendiri dan atau orang lain, ingin atau perlu dihilangkan. Belajar juga diartikan sebagai sesuatu proses yang dilakukan individu untuk memperoleh suatu perubahan tingkah laku yang baru secara keseluruhan, sebagai hasil pengalaman individu itu sendiri dalam interaksi dengan lingkungannya. Jadi masalah belajar adalah suatu kondisi tertentu yang dialami oleh murid dan menghambat kelancaran proses yang dilakukan individu untuk memperoleh suatu perubahan tingkah laku yang baru secara keseluruhan. Kondisi tertentu itu dapat berkenaan dengan keadaan dirinya yaitu berupa kelemahan-kelemahan dan dapat juga berkenaan dengan lingkungan yang tidak menguntungkan bagi dirinya. Masalahmasalah belajar ini tidak hanya dialami oleh murid-murid yang lambat saja dalam belajarnya, tetapi juga dapat menimpa murid-murid yang pandai atau cerdas.

\section{B. JENIS JENIS MASALAH BELAJAR}

Jenis-jenis masalah belajar Di Sekolah dapat dikelompokkan kepada murid-murid yang mengalami.

1. Keterlambatan akademik, yaitu keadaan murid yang diperkirakan memiliki intelegensi yang cukup tinggi, tetapi tidak dapat memanfaatkan secara optimal. 
2. Kecepatan dalam belajar, yaitu keadaan murid yang memiliki bakat akademik yang cukup tinggi atau memilki IQ 130 atau lebih, tetapi masih memerlukan tugas-tugas khusus untukmemenuhi kebutuhan dan kemampuan belajarnya yang amat tinggi.

3. Sangat lambat dalam belajar, yaitu keadaan murid yang memilki bakat akademik yang kurang memadai dan perlu dipertimbangkan untuk mendapatkan pendidikan atau pengajaran khusus.

4. Kurang motivasi belajar, yaitu keadaan murid yang kurang bersemangat dalam belajar, mereka seolah-olah tampak jera dan malas.

5. Bersikap dan kebiasaan buruk dalam belajar, yaitu kondisi murid yang kegiatannya tau perbuatan belajarnya sehari-hari antagonistik dengan seharusnya, seperti suka menunda-nunda tugas, mengulur-ulur waktu, membenci guru, tidak mau bertanya untuk hal-hal yang tidak diketahui dan sebagainya.

6. Sering tidak sekolah, yaitu murid-murid yang sering tidak hadir atau menderita sakit dalam jangka waktu yang cukup lama sehingga kehilanggan sebagian besar kegiatan belajarnya.

Menurut Modul Diagnostik Kesulitan Belajar Dan Pengajaran Remedial, beberapa ciri-ciri tingkah laku yang merupakan pernyataan manifestasi gejala kesulitan belajar antara lain :

1. Menunjukan hasil belajar yang rendah di bawah rata-rata nilai yang dicapai oleh kelompoknya atau dibawah potensi yang dimilikinya.

2. Hasil yang dicapai tidak seimbang dengan usaha yang telah dilakukan. Mungkin ada murid yang selalu berusaha untuk belajar dengan giat tetapi nilai yang dicapainya selalu rendah

3. Lambat dalam melakukan tugas-tugas kegiatan belajar. Ia selalu tertinggal dari teman-temannya dalam menyelesaikan tugastugas sesuai dengan waktu yang tersedia. 
4. Menunjukkan sikap yang kurang wajar, seperti acuh tak acuh, menentang,berpura-pura, dusta dan sebagainya.

5. Menunjukkan tingkah laku yang berkelainan, seperti membolos, datang terlambat, tidak mengerjakan pekerjaan rumah, menganggu dalam atau di luar kelas, tidak mau mencatat pelajaran, tidak teratur dalam kegiatan belajar, mengasingkan diri, tersisihkan, tidak mau bekerja sama dan sebagainya.

6. Menunjukkan gejala emosional yang kurang wajar, seperti : pemurung, mudah tersinggung, pemarah, tidak atau kurang gembira dalam menghadapi situasi tertentu misalnya dalam menghadapi nilai rendah tidak menunjukkan adanya perasaan sedih atau menyesal, dan lain sebagainya.

\section{C.FAKTOR-FAKTOR PENYEBAB TIMBULNYA MASALAH BELAJAR}

\section{Faktor yang Bersumber dari Diri Pribadi (Internal)}

Faktor yang bersumber dari diri pribadi sendiri yaitu :

\section{a. Faktor Psikologis}

1) Intelegensi; Siswa yang mempunyai intelegensi tinggi akan lebih mudah dalam memahami pelajaran yang diberikan guru atau lebih berhasil dibandingkan dengan siswa-siswa yang berintelegensi rendah.

2) Bakat; Apabila bahan yang dipelajari oleh siswa tidak sesuai dengan bakatnya maka siswa akan mengalami kesulitan dalam belajar.

3) Motivasi; Prestasi belajar siswa bisa menurun apabila siswa tersebut tidak mempunyai motivasi dalam belajar.

\section{b. Faktor Fisiologis}

Gangguan-gangguan fisik dapat berupa gangguan pada alat-alat penglihatan dan pendengaran yang dapat menimbulkan kesulitan belajar. Seperti gangguan visual yang sering disertai dengan gejala pusing, mual, sakit kepala, malas, dan kehilangan konsentrasi pada pelajaran.

\section{Faktor Eksternal}




\section{a. Faktor yang Bersumber dari Lingkungan Sekolah :}

1) Metode mengajar; Apabila guru menggunakan metode yang sama untuk semua bidang studi dan pada setiap pertemuan akan membosankan siswa dalam belajar.

2) Hubungan guru dengan guru, guru dengan siswa, dan siswa dengan siswa; Dalam proses pendidikan, antar guru, guru dengan siswa, dan antar siswa tidak terjalin hubungan yang baik dan harmonis untuk bekerja sama, maka siswa akan mengalami kesulitan dalam belajar.

3) Sarana dan prasarana; Alat-alat belajar yang kurang atau tidak lengkap, buku-buku sumber yang diperlukan sulit didapatkan, ruang kelas, ruang kelas tidak mencukupi syarat seperti terlalu panas, pengap, dan ruang kecil yang tidak sesuai dengan jumlah siswa.

\section{b. Faktor Keluarga}

1) Keadaan ekonomi keluarga; Apabila anak hidup dalam keluarga yang miskin dan harus bekerja membantu mencari tambahan ekonomi keluarga akan menimbulkan kesulitan bagi anak, mungkin akan terlambat datang, tidak dapat membeli peralatan sekolah yang dibutuhkan, tidak dapat memusatkan perhatian karena sudah lelah dan sebagainya.

2) Hubungan antar sesama anggota keluarga; Apabila hubungan antar keluarga tidak harmonis, seperti orang tua sering bertengkar, orang tua otoriter, peraturan yang ketat, dan sebagainya, maka anak tidak bisa berkonsentrasi dalam belajar.

3) Tuntutan orang tua; Tuntutan orang tua dapat menimbulkan kesulitan belajar bagi anak apabila tuntutan itu tidak sesuai dengan kemampuan, minat, dan bakat anak.

\section{c. Faktor Lingkungan Masyarakat}

Faktor yang bersumber dari lingkungan masyarakat yang dapat menimbulkan kesulitan belajar adalah media cetak, komik, 
buku-buku pornografi, media elektronik, TV, VCD, video, play station, dan sebagainya.

\section{FAKTOR-FAKTOR}

PENYEBAB

MUNCULNYA

\section{MASALAH-MASALAH DALAM PEMBELAJARAN}

Para ahli seperti Cooney, Davis \& Henderson (1975) telah mengidentifikasikan beberapa faktor penyebab masalah pembelajaran, di antaranya:

\section{Faktor Fisiologis}

Faktor-faktor yang menjadi penyebab masalah belajar peserta didik ini berkait dengan kurang berfungsinya otak, susunan syaraf ataupun bagian-bagian tubuh lain. Para guru harus menyadari bahwa hal yang paling berperan pada waktu belajar adalah kesiapan otak dan sistem syaraf dalam menerima, memproses, menyimpan, ataupun memunculkan kembali informasi yang sudah disimpan. Kalau ada bagian yang tidak sesuai pada bagian tertentu dari otak seorang peserta didik, maka dengan sendirinya peserta didik akan mengalami masalah belajar. Seandainya sistem syaraf atau otak peserta didik karena sesuatu dan lain hal kurang berfungsi secara sempurna akibatnya akan mengalami hambatan ketika belajar.

\section{Faktor Sosial}

Merupakan suatu kenyataan yang tidak dapat dibantah jika orang tua dan masyarakat sekeliling sedikit banyak akan berpengaruh terhadap kegiatan belajar dan kecerdasan peserta didik sebagaimana ada yang menyatakan bahwa sekolah adalah cerminan masyarakat dan anak adalah gambaran orang tuanya. Oleh karena itu ada beberapa faktor penyebab masalah belajar yang berkait dengan sikap dan keadaan keluarga serta masyarakat sekeliling yang kurang mendukung peserta didik tersebut untuk belajar sepenuh hati. Tetangga yang mengatakan sekolah tidak penting karena banyak sarjana menganggur, masyarakat yang selalu minum-minuman keras dan melawan hukum, ada orang tua yang selalu marah bila menonton TV setiap saat, ada juga yang tidak 
terbuka ataupun kurang menyayangi anaknya dengan sepenuh hati dapat merupakan contoh dari beberapa faktor sosial yang menjadi penyebab masalah belajar peserta didik.

\section{Faktor Kejiwaan}

Faktor-faktor yang menjadi penyebab masalah belajar peserta didik ini berkait dengan kurang mendukungnya perasaan hati (emosi) peserta didik unutuk belajar secara sungguh-sungguh. Sebagai contoh, ada peserta didik yang tidak suka mata pelajaran tertentu karena ia selalu gagal mempelajari mata pelajaran itu. Jika hal ini terjadi, peserta didik tersebut akan mengalami masalah belajar yang sangat berat. Hal ini merupakan contoh dari faktor emosi yang menyebabkan masalah belajar.

\section{Faktor Intelektual}

Faktor-faktor yang menjadi penyebab masalah belajar peserta didik ini berkait dengan kurang sempurna atau kurang normalnya tingkat kecerdasan peserta didik. Para guru harus meyakini bahwa setiap peserta didik mempunyai tingkat kecerdasan berbeda. Ada peserta didik yang sangat sulit menghafal sesuatu, ada yang sangat lamban menguasai materi tertentu, ada yang tidak memiliki pengetahuan prasyarat dan juga ada yang sangat sulit membayangkan dan bernalar.

\section{Faktor Kependidikan}

Faktor-faktor yang menjadi penyebab masalah belajar peserta didik ini berkait dengan belum mantapnya lembaga pendidikan secara umum. Guru yang selalu meremehkan peserta didik, guru yang tidak bisa memotivasi peserta didik untuk belajar lebih giat, guru yang membiarkan peserta didiknya melakukan hal-hal yang salah, guru yang tidak pernah memeriksa pekerjaan peserta didik, sekolah yang membiarkan para peserta didik bolos tanpa ada sanksi tertentu, adalah contoh dari faktor-faktor penyebab masalah dan pada akhirnya akan menyebabkan ketidak berhasilan peserta didik tersebut. 


\section{E. MASALAH-MASALAH DALAM PEMBELAJARAN}

Masalah-masalah yang muncul dalam pembelajaran dapat dibedakan sebagai berikut:

\section{Dari segi guru}

a. Guru mendapat kesulitan menerapkan metode pembelajaran yang tepat dan bervariasi.

b. Kepribadian guru secara keseluruhan belum bisa diteladani peserta didik.

c. Penerapan tugas sebagai pengajar, pendidik, pelatih belum dapat berjalan optimal.

d. Guru mendapat kesulitan dalam menentukan dan mengidentifikasi materi esensial dan materi sulit.

e. Komitmen, kinerja, dan keikhlasan guru dalam merencanakan dan melaksanakan pembelajaran belum sesuai harapan.

f. Guru masih mengandalkan Lembaran Kegiatan Peserta didik (LKS) yang dijual penerbit untuk pekerjaan rumah peserta didik karena kesulitan dalam mengembangkan LKS sendiri.

g. Guru kesulitan menerapkan disiplin bagi peserta didik dalam belajar.

h. Kemampuan guru masih kurang dalam mengelola laboratorium, sehingga kesulitan menyajikan materi sains secara praktek.

i. Guru kesulitan dalam mengembangkan media pembelajaran yang sesuai.

j. Guru kesulitan membuat alat evaluasi belajar dan mengembangkan Emosional Spiritual Question (ESQ).

\section{Dari segi kurikulum}

a) Isi kurikulum yang padat menyulitkan guru untuk mencapai target yang hendak dicapai dan menerapkan pendidikan pada peserta didik sehingga menghambat kemampuan peserta didik berpikir tingkat tinggi. 
b) Pelaksanaan kurikulum dan evaluasi hasil belajar cenderung pada ranah kognitif, sehingga ranah afektif dan psikomotor cenderung tidak diterapkan.

c) Materi cenderung lebih tinggi untuk tingkat kemampuan peserta didik.

d) Kurikulum yang sering berubah membuat guru sulit menjalankannya di sekolah.

\section{Dari segi peserta didik}

a) Minat baca, motivasi belajar, dan daya nalar peserta didik relatif rendah.

b) Kemandirian dan strategi belajar kurang baik.

c) Kurang efektif memanfaatkan waktu dan sumber belajar.

d) Aktivitas bertanya di kelas rendah.

e) Mudah terpengaruh oleh dampak negatif teknologi.

\section{Dari segi manajerial}

a) Kurangnya perhatian pimpinan terhadap sarana dan prasarana sains baik laboratorium maupun media.

b) Pelatihan meningkatkan mutu guru belum merata.

c) Supervisi oleh kepala sekolah dan pengawas belum optimal.

d) Kurangnya reward bagi guru yang kinerja baik, dan sebaliknya.

\section{Dari segi orang tua}

a) Kurangnya perhatian orang tua, disiplin, kepedulian, bimbingan belajar, dan fasilitas belajar di rumah.

b) Kuatnya pengaruh televisi di rumah sedangkan orang tua tidak dapat mencegahnya.

c) Banyaknya orang tua yang tidak mengenali bakat anaknya.

d) Tingginya harapan orang tua dibandingkan kemampuan anaknya. 


\section{Dari segi pemerintah}

a) Kurang optimalnya perhatian pemerintah dalam pengadaan sarana, fasilitas laboratorium, dan buku-buku perpustakaan sekolah.

b) Adanya intervensi birokrat yang terlalu jauh terhadap kebijakan pendidikan. Misalnya pengangkatan kepala sekolah.

\section{Dari segi lingkungan atau masyarakat}

a) Lingkungan masyarakat kurang kondusif mendukung suasana belajar.

b) Kemajuan teknologi berpengaruh negatif terhadap konsentrasi belajar peserta didik.

c) Pendidikan agama kurang memadai.

d) Tidak aktifnya kegiatan organisasi di masyarakat yang dapat membangun kreativitas peserta didik.

\section{F. UPAYA PENGENTASAN MASALAH BELAJAR}

Murid yang mengalami masalah belajar perlu mendapat bantuan agar masalahnya tidak berlarut-larut nantinya dan siswa yang mengalami masalah belajar ini dapat berkembang secara optimal. Beberapa upaya yang dapat dilakukan menurut Prayitno ( 1994 ; 9499) sebagai berikut :

\section{Pengajaran perbaikan}

Pengajaran perbaikan merupakan suatu bentuk layanan yang diberikan kepada seseorang atau sekelompok siswa yang menghadapi masalah-masalah belajar dengan maksud untuk memperbaiki kesalahkelasalahan dalam proses dan hasil belajar siswa. Bentuk kesalahan yang paling pokok berupa salah pengertian, salah pemahaman, salah menafsirkan dan tidak menguasai konsep-konsep dasar. Dengan memperbaiki kesalahan-kesalahan itu maka siswa mempunyai kesempatan untuk mencapai hasil belajar yang optimal.

\section{Kegiatan pengayaan}

Kegiatan pengayaan merupakan suatu bentuk layanan yang diberikan kepada seseorang atau beberapa orang siswa yang sangat 
cepat dalam belajar. Siswa yang cepat dalam belajar mempunyai sisa waktu yang berlebih dalam belajar, untuk itu mereka memerlukan tugas-tugas tambahan yang terencana untuk menambah atau memperluas pengetahuan dan keterampilan yang telah dimilikinya dalam kegiatan belajar sebelumnya.

\section{Peningkatan motivasi belajar}

Di sekolah sebagian siswa mungkin, telah memiliki motif yang kuat, untuk belajar, tetapi sebagian lain mungkin belum. Disisi lain, mungkin juga ada siswa yang semula motifnya amat kuat, tetapi menjadi pudar. Tingkah laku seperti kurang bersemangat, jera, malas, bosan dan sebagainya dapat dijadikan indikator kurang kuatnya motif (motivasi) dalam belajar.

Guru bidang studi, guru pembimbing dan staf sekolah lainnya berkewajiban membantu siswa meningkatkan motivasi siswa dalam belajar. Prosedur-prosedur yang dapat dilakukan menurut Prayitno (1994) adalah :

a) Memperjelas tujuan-tujuan belajar, siswa akan didorong untuk lebih giat belajar apabila ia mengetahui tujuan-tujuan atau sasaran yang hendak dicapai

b) Menyesuaikan pengajaran dengan bakat, kemampuan dan minat siswa

c) Menciptakan suasana pembelajaran yang menantang, merangsang dan menyenangkan

d) Memberikan hadiah ( penguatan dan hukuman bila perlu)

e) Menciptakan suasana hubungan yang hangat dan dinamis antara guru dan murid, serta antara murid dengan murid.

f) Menghindari tekanan-tekanan dan suasana yang tidak menentu (seperti suasana yang menakutkan, mengecewakan, membingungkan, menjengkelkan)

g) Melengkapi sumber dan peralatan mengajar.

\section{Pengembangan sikap dan kebiasaan belajar yang baik}

Setiap siswa diharapkan menerapkan sikap dan kebiasaan yang belajar yang efektif. Tetapi masih ada siswa yang yang mengamalkan 
sikap dan kebiasaan belajar yang tidak diharapkan dan tidak efektif. Bila siswa tidak memiliki sikap dan kebiasaan belajar yang baik maka dikhwatirkan siswa tersebut tidak akan mencapai hasil belajar yang baik. Prestasi belajar yang baik itu diperoleh melalui usaha atau bahkan kerja keras.

\section{Layanan konseling individual}

Konseling dimaksud sebagai pelayanan khusus dalam hubungan langsung tatap muka antara konselor dan klien. Dalam hubungan tata muka ini klien dapat menyampaikan masalah-masalah yang dirasakan pada konselor dan masalah itu bisa dicermati dan diupayakan pengentasannya melalui pembahasan dengan konselor.

\section{G.UPAYA MENGATASI MASALAH-MASALAH DALAM PEMBELAJARAN}

Untuk mencegah dan mengatasi masalah-masalah yang dapat muncul dalam pembelajaran dapat dapat dilakukan berbagai upaya sebagai berikut:

\section{Dari segi guru}

a) Guru harus menguasai kompetensi guru yang meliputi kompetensi pedagogik, kepribadian, sosial, dan profesional (sesuai U No. 14 Tahun 2005) atau kompetensi profesional, sosial dan personal (sesuai Depdikbud 1990).

b) Guru harus menguasai 10 kompetensi dasar guru yang meliputi penguasaan bahan pelajaran beserta konsep-konsep dasar keilmuannya, pengelolaan program belajar mengajar, pengelolaan kelas, pengelolaan dan penggunaan media dan sumber pembelajaran, penguasaan landasan-landasan kependidikan, pengelolaan interaksi belajar mengajar, penilaian prestasi belajar siswa, pengenalan fungsi dan program bimbingan dan penyuluhan, pengenalan administrasi sekolah dan pemahaman prinsip-prinsip dan melakukan penelitian serta pemanfaatan hasil penelitian pendidikan untuk kepentingan peningkatan mutu pembelajaran. 
c) Guru harus menguasai 10 keterampilan dasar guru yang meliputi keterampilan bertanya, memberi penguatan, mengadakan variasi, menjelaskan, membuka dan menutup pelajaran, membimbing diskusi kelompok kecil, mengelola kelas, mengajar kelompok kecil dan perorangan, mengembangkan dan menggunakan media serta mengembangkan ESQ.

d) Guru harus menguasai 10 prinsip dalam pembelajaran.

\section{Dari segi siswa}

a) Siswa harus meningkatkan minat baca dengan memotivasi diri belajar dari hal yang dianggap mudah.

b) Siswa harus berusaha membagi waktu seefisien mungkin.

c) Selektif dalam menggunakan teknologi.

3. Dari segi kurikulum: Merevisi kurikulum yang ada agar dapat diterapkan dalam tiga ranah pembelajaran (kognitif, afektif, psikomotor), bukan melakukan penggantian kurikulum tersebut.

4. Dari segi manejerial: Peningkatan kinerja manejerial dari segi sarana dan prasarana serta kualitas guru untuk perbaikan proses pembelajaran.

5. Dari segi orang tua: Orang tua perlu meningkatkan kepedulian terhadap prestasi belajar anaknya dengan mengontrol penggunaan teknologi dan mengenali bakat anak sehingga dapat mengarahkan untuk menekuni bidang yang tepat.

6. Dari segi pemerintah: Perlunya optimalisasi perhatian pemerintah dalam pengadaan sarana dan prasarana dalam pengadaan sarana, fasilitas laboratorium, dan buku-buku perpustakaan sekolah dan minimalisasi intervensi birokrat yang terlalu jauh terhadap kebijakan pendidikan.

7. Dari segi masyarakat: Menciptakan lingkungan yang kondusif untuk mendukung suasana belajar seperti mengontrol penggunaan internet untuk pelajar, mengaktifkan kegiatan organisasi yag dapat membangun kreativitas peserta didik. 
Oleh karena itu, perilaku siswa dan lingkungan kelas memengaruhi satu sama lain dalam berbagai hal cara. Pertimbangkan urutan instruksi tipikal di mana guru menyajikan informasi dan meminta siswa untuk mengarahkan perhatian mereka ke papan tulis. Pengaruh lingkungan terhadap perilaku terjadi ketika siswa melihat papan tulis tanpa banyak pertimbangan sadar (lingkungan-perilaku). Perilaku siswa sering mengubah lingkungan pengajaran. Jika guru mengajukan pertanyaan dan siswa memberikan jawaban yang salah, guru dapat melakukan penelitian kembali beberapa poin daripada melanjutkan pelajaran (perilaku $\rightarrow$ lingkungan) (Dale $\mathrm{H}$. Schunk,2012).

Dapat disimpulakan dari penjelasan di atas bahwa problematika pendidikan merupakan persoalan-persoalan yang di hadapi oleh dunia pendidikan, khususnya Negara Indonesia. Dunia pendidikan kita masih menghadapi berbagai masalah internal yang cukup mendasar dan bersifat kompleks. Kita masih menghadapi sejumlah masalah yang sifatnya berantai sejak jenjang pendidikan dasar sampai pendidikan tinggi. Rendahnya kualitas pada jenjang sekolah dasar sangat penting untuk segera diatasi karena sangat berpengaruh terhadap pendidikan selanjutnya. 


\section{BAB XII \\ KONSEP DASAR EVALUASI BELAJAR DAN \\ PEMBELAJARAN}

Pembelajaran di Perguruan Tinggi maupun di sekolah adalah sebuah interaksi antara peserta didik dalam mempelajari suatu materi pelajaran yang telah tersusun dalam suatu kurikulum yang telah dibuat oleh pemerintah. Dalam pelaksanaannya perlu dilakukan evaluasi atau upaya perbaikan pembelajaran. Evaluasi masukan pembelajaran menekankan pada evaluasi karakteristik peserta didik, kelengkapan dan keadaan sarana dan prasarana pembelajaran dan lain-lain.

Evaluasi hasil pembelajaran atau evaluasi hasil belajar antara lain menggunakan tes untuk melakukan pengukuran hasil belajar sebagai prestasi belajar, dalam hal ini adalah penguasaan kompetensi oleh setiap siswa. Terkait dengan ketiga jenis evaluasi pembelajaran tersebut, dalam praktek pembelajaran secara umum pelaksanaan evaluasi pembelajaran menekankan pada evaluasi proses pembelajaran atau evaluasi manajerial, dan evaluasi hasil belajar atau evaluasi substansial. Hal ini didasarkan pada pemikiran bahwa dalam pelaksanaan pembelajaran kedua jenis evaluasi tersebut merupakan komponen sistem pembelajaran yang sangat penting. Evaluasi kedua jenis komponen yang dapat dipergunakan untuk mengetahui kekuatan dan kelemahan pelaksanaan dan hasil pembelajaran. Selanjutnya masukan tersebut pada gilirannya dipergunakan sebagai bahan dan dasar memperbaiki kualitas proses pembelajaran menuju ke perbaikan kualitas hasil pembelajaran.

Mengingat pentingnya seorang guru mengetahui mengenai pelaksanaan evaluasi ini, perlulah disusun makalah yang membahas mengenai konsep dasar evaluasi belajar dan pembelajaran dengan harapan agar evaluasi dapat dilaksanaan dengan sebagaimana mestinya. 


\section{A. PENGERTIAN, KEDUDUKAN \& SYARAT-SYARAT UMUM EVALUASI}

\section{Pengertian evaluasi}

Evaluasi secara umum dapat diartikan sebagai proses sitematis untuk menentukan nilai sesuatu (tujuan, kegiatan, keputusan, unjukkerja, proses, orang, objek, dan yang lain) berdasarkan kriteria tertentu melalui penilaian. Beberapa pengertian evaluasi menurut para ahli:

a) Davies mengemukakan bahwa evaluasi merupakan proses sederhana memberikan/menetapkan nilai kepada sejumlah tujuan, kegiatan, keputusan, unjuk-kerja, proses, orang, objek, dan masih banyak yang lain.

b) Wand dan Brown mengemukakan evaluasi merupakan suatu proses untuk menentukan nilai dari sesuatu.

Dapat disimpulkan bahwa evaluasi hasil belajar merupakan proses untuk menentukan nilai belajar siswa melalui kegiatan penilaian dan/atau pengukuran hasil belajar. Untuk menentukan nilai sesuatu dengan cara membandingkan dengan kriteria, evaluator dapat langsung membandingkan dengan kriteria namun dapat pula melakukan pengukuran terhadap sesuatu yang dievaluasi kemudian baru membandingkan dengan kriteria. Dengan begitu evaluasi tidak selalui melalui proses mengukur (pengukuran) baru melakukan prose menilai (penilaian) tetapi dapat pula evaluasi langsung melalui penilaian saja.

Pengukuran lebih menekankan kepada proses penentuan kuantitas sesuatu melalui membandingkan dengan satuan ukuran tertentu. Sedangkan penilaian meekankan kepada proses pembuatan keputusan terhadap sesuatu ukuran baik-buruk yang bersifat kualitatif. Dari batasan pengukuran dan penilaian, dapat ditadai adanya perbedaan yang nyata antara keduanya.

Dengan kata lain evaluasi belajar dan pembelajaran adalah proses untuk menentukan nilai belajar dan pembelajaran yang dilaksanakan, dengan melalui kegiatan penilaian atau pengukuran 
belajar dan pembelajaran. Sedangkan pengertian pengukuran dalam kegiatan belajar dan pembelajaran adalah proses membandingkan tingkat keberhasilan belajar dan pembelajaran dengan ukuran keberhasilan belajar dan pe,belajaran yang telah ditentukan secara kuantitatif. Pengertian penilaian belajar dan pembelajaran adalah proses pembuatan kepurusan nilai keberhasilan belajar dan pembelajaran secara kualitatif.

\section{Kedudukan Evaluasi dalam Proses Pendidikan}

Proses pendidikan merupakan proses pemanusian manusia, di mana di dalamnya terjadi proses membudayakan dan meradabkan manusia. Agar terbentuk manusia yang berbudaya dan beradab, maka diperlukan transformasi kebudayaan dan perdaban.

Tranformasi dalam proses pendidikan dalah proses untuk membudayakan dan memberdabkan siswa. Lembaga pendidikan merupakan tempat terjadinya tranformasi. Keberhasilan transformasi untuk menghasilkan keluaran seperti yang diharapkan dipengaruhi atau ditentukan oleh bekerjanya kompinen atau unsur yang ada dalam lembaga pendidikan. Unsur-unsur transformasi dalam proses pendidikan, meliputi:

a. Pendidik dan personal lainnya,

b. Isi pendidikan,

c. Teknik,

d. Sistem evaluasi,

e. Sarana pendidikan,

f. Sitem administrasi.

Untuk mengetahui efisisensi dan efektivitas transformasi dalam proses pendidikan perlu dilasanakan evaluasi terhadap bekerjanya unsur-unsur transformasi. Umpan balik dalam proses pendidikan adalah segala informasi yang berhasil diperoleh selama proses pendidikan yang digunakan sebagai bahan pertimbangan untuk perbaikan masukan dan transformasi yang ada dalam proses. Adanya umpan balik yag akurat sebagai hasil evaluasi yang akurat pula, akan memudahkan kegiatan perbaikan proses penddikan. 
Dapat kita lihat bahwa setiap unsur yang ada pada proses tranformasi pendidikan membutuhkan kegiatan evaluasi. Dengan demikian jelaslah bahwa kedudukan evaluasi dalam proses pendidikan bersifat integratif, artinya setiap ada proses pendidikan pasti ada evaluasi. Seperti kita ketahui juga bahwamengadakan kegiatan evaluasi mulai sejak siswa akan memasuki proses pendidikan, selama proses pendidikan, dan berakhir pada satu tahap proses pendidikan.

\section{Syarat-Syarat Umum Evaluasi}

Syarat-syarat umum yang harus dipenuhi dalam mengadakan kegiatan evaluasi dalam proses pendidikan terurai sebagai berikut:

\section{a. Kesahihan}

Kesahihan diartikan sebagai ketepatan evaluasi mengevaluasi apa yang seharusnya dievaluasi. Kesahihan dapat diterjemahkan pulai sebagai kelayakan interpretasi terhadap hasil dari suatu instrimen evaluasi atau tes, dan tidak terhadap instrumen itu sendiri. Untuk memperoleh hasil evaluasi yang sahih, dibutuhkan instrumen yang memiliki/memenuhi syarat-syarat kesahihan suatu instrumen evaluasi. Kesahihan instrumen evaluasi diperoleh melalui hasil pemikiran dan hasil pemglaman. Faktorfaktor yang mempengaruhi kesahihan hasil evaluasi meliputi:

1) Faktor instrumen evaluasi itu sendiri. Adapun hal-hal yang menyebabkan atau mempengaruhi hasil evaluasi yang ada dalam intrumen evaluasi, diantaranya ketidak-jelasan petunjuk, tingkat kesulitan kosa kata dan struktur kalimat instrumen evaluasi, ketidaklayakan tingkat kesulitan item evaluasi, susunan item evaluasi yang kurang baik, item evaluasi yang terlalu pendek, dan dapat dikebalinya pola jawaban instrumen evaluasi.

2) Faktor-faktor administrasi evalluasi dan penskoran,juga merupakan faktor-faktor yang mempunyai suatu pengaruh yang mengganggu kesahihan interpretasi hasil evaluasi. Dalam kasus intrumen evaluasi guru, faktor-faktor tersebut 
diantaranya berupa waktu yang tidak cukup untuk menyelesaikan evaluasi, bantuan secara tak wajar kepada individu siswa yang meminta pertolongan, mencontek saat ujian, dan penskoran jawaban esai yang tidak dapat diperoleh karena cenderung ke arah kesahihan yang rendah.

3) Faktor-faktor dalam respons-respons siswa merupakan faktorfaktor yang lebih banyak mempengaruhi kesahihan dari pada faktor yang ada dalam instrumen evaluasi atau pengadministrasiannya.

Dari uraian jelaslah bahwa faktor-faktor yang mempengaruhi kesahihan adalah faktor-faktor dalam instrumen evaluasi, faktorfaktor dalam pengadministrasian dan penskoran evaluasi, dan faktorfaktor dalam respons-respons siswa.

\section{b. Keterandalan}

Keterlandalan evaluasi berhubungan dengan masalah kepercayaan, yakni tingkat kepercayaan bahwa suatu instrumen evaluasi mampu memberikan hasil yang tepat. Gronlund juga mengemukakan bahwa keterlandalan menunjuk kepada konsistensi (keajegan) pengukuran yakni bagaimanakah keajegan skor tes atau hasil evaluasi lain yang berasal dari pengukuran yang satu ke pengukuran yang lain. Dengan kata lain, keterandalan dapat kita artikan sebagai tingkat kepercayaan keajegan hasil evaluasi yang diperoleh dari suatu instrumen evaluasi. Keterandalan berhubungan erat dengan kesahihan, karena keterandalan menyediakan keajegan yang memungkinkan terjadinya kesahihan. Sedangkan grounlund mengemukakan adanya 4 (empat) faktor yang mempengaruhi keterandalan, yakni:

1) Panjang tes (length of test). Panjang tes berhubungan dengan banyaknya butir tes, pada umumnya lebih banyak butir tes lebih tinggi keterandalan evaluasi. Hal ini terjadi karena makin banyak soal tes makin banyak sampel yang diukur, proporsi jawaban benar makin banyak 
2) Sebaran skor (spread of scores). Koefisien keterandalan secara langsung dipengaruhi oleh sebaran skor dalam kelompok tercoba. Karena koefisien keterandalan yang lebih besar dihasilkan pada saat orang perorang tetap pada posisi yang relatif sama dalam satu kelompok dari satu pengujian ke pengujian lainnya.

3) Tingkat kesulitan tes (difficulty of tes). Tes acuan norma (norm referenced test) yang paling mudah atau paling sukar untuk anggota-anggota kelompok yang mengerjakan, cenderung menghasilkan skor tes keterandalan yang rendah. Ini disebabkan antara hasil tes yang mudah dan yang sulit keduanya dalam satu sebara skor yang terbatas. Untuk kedua tes (mudah dan sukar), perbedaan antarorang perorang kecil sekali dan cenderung tidak dapat dipercaya.

4) Objektivitas (objectivity). Objektivitas suatu tes menunjuk kepada tingkat skor kemampuan yang sama (yang dimiliki oleh siswa satu dengan yang lain) memperoleh hasil yang sama dalam mengerjakan tes. Dengan kata lain, apabila ada siswa yang memiliki tingkat kemampuan yang sama dengan tingkat kemampuan siswa yang lain maka dapat dipastikan akan memperoleh hasil tes yang sama pada saat mengerjakan tes yang sama.

Uraian faktor-faktor yang mempengaruhi keterandalan yang disadur dari Gronlund mencakup faktor-faktor yang mempengaruhi keterandalan yang dikemukakan oleh Arikunto.

\section{c. Kepraktisan}

Kepraktisan evaluasi dapat diartikan sebagai kemudahankemudahan yang ada pada instrumen evaluasi baik dalam mempersiapkan, menggunakan, menginterpretasi / memperoleh hasil, maupun kemudahan dalam menyimpannya. Faktor-faktor yang mempengaruhi kepraktisan instrumen evaluasi meliputi:

1) Kemudahan mengadministrasi, untuk memberikan kemudahan pengadministrasian instrument evaluasi dapat dilakukan 
dengan jalan memberikan petunjuk yang sederhana dan jelas, subtes sebaiknya relative sedikit dan pengaturan tempo tes sebaiknya tidak menimbulkan kesulitan;

2) Waktu yang disediakan untuk melancarkan evaluasi, kepraktisan dipengaruhi pula oleh waktu yang disediakan untuk melancarkan evaluasi;

3) Kemudahan menskor, untuk memberikan kemudahan penskoran diperlukan pengembangan berupa perbaikan petunjuk untuk penskoran dan lebih memudahkan kunci penskoran;

4) Kemudahan interpretasi dan aplikasi, untuk memudahkan interpretasi dan aplikasi hasil evaluasi diperlukan petunjuk yang jelas. Semakin mudah interpretasi dan aplikasi hasil evaluasi, semakin meningkatkan kepraktisan evaluasi;

5) Tersedianya bentuk instrument evaluasi yang ekuivalen atau sebanding,

\section{B. FUNGSI, TUJUAN DAN SASARAN EVALUASI HASIL}

BELAJAR

\section{Fungsi dan Tujuan Evaluasi Hasil Belajar}

Evaluasi hasil belajar merupakan proses untuk menentukan nilai belajar siswa melalui kegiatan penilaian dan/atau pengukuran hasil belajar. Tujuan utamanya adalah untuk mengetahui tingkat keberhasilan yang dicapai oleh siswa setelah mengikuti suatu kegiatan pembelajaran, dimana tingkat keberhasilan tersebut kemudian ditandai dengan skala nilai berupa huruf atau kata atau simbol. Hasil dari kegiatan evaluasi hasi belajar pada akhirnya difungsikan dan ditujukan untuk keperluan berikut ini:

a) Untuk diagnostic dan pengembangan, artinya penggunaan hasil dari kegiatan evaluasi hasil belajar sebagai dasar pengdiagnosisan kwlwmahan dan keunggulan siswa beserta sebab-sebabnya, berdasarkan pengdiagnosisan inilah guru mengadakan pengembangan kegiatan pembelajaran untuk meningkatkan hasi belajar siswa. 
b) Untuk seleksi, hasil dari kegiatan evaluasi seringkali digunakan sebagai dasar untuk menentukan siswa-siswa yang paling cocok untuk jenis jabatan atau jenis pendidikan tertentu.

c) Untuk kenaikan kelas, berdasarkan hasil dari kegiatan evaluasi hasil belajar siswamengenai sejumlah isi pelajaran yang telah disajikan dalam pembelajaran, maka guru dapat dengan mudah membuat keputusan kenaikan keas berdasarkan ketentuan yang berlaku.

d) Untuk penempatan, agar siswa dapat berkembang sesuai dnegan tingkat kemampuan dan potensi yang mereka miliki, maka perlu dipikirkan ketepatan penempatan siswa pada kelompok yang sesuai.

\section{Sasaran Evaluasi Hasil Belajar}

Evaluasi hasil belajar memiliki ssasaran berupa ranah-ranah yang terkandung dalam tujuan. Ranah tujuan pendidikan berdasarkan hasil beajar siswa secara umum diklasifikasikan menjadi tiga yakni: ranah kognitif, ranah afektif dan ranah psikomotorik. Taksonomi tujuan ranah kognitif dikemukakan oleh Bloom (1956). Selain itu, pada tahun 1964, Krathwohl, Bloom, dan Masia mengemukakan ranah afektif dari taksonomi tujuan pendidikan. Sedangkan taksonomi tujuan ranah psikomotorik dikemukakan oleh Harrow pada tahun 1972.

Tujuan ranah kognitif berhubungan dengan ingatan atau pengenalan terhadap pengetahuan dan informasi serta pengembangan keterampilan intelektual. Taksonomi tujuan ranah kognitif oleh Bloom mengemukakan adanya 6 kelas yaitu:

a) Pengetahuan, merupakan tingkat terendah tujuan ranah kognitif berupa pengenalan dan pengingatan kembali terhadap pengetahuan tentang fakta, istilah, dan prinsip-prinsip dalam bentuk seperti mempelajari. Dalam pengenalasn siswa diminta untuk memilih salah satu dari dua atau lebih pilihan jawaban;

b) Pemahaman, berupa kemampuan memahami/mengerti tentang isi pelajaran yang dipelajari tanpa perlu menghubungkannya 
dengan isi pelajaran lainnya. Dalam pemahaman siswa diminta untuk memmbuktikan bahwa ia memahami hubungan yang sederhana diantara fakta-fakta atau konsep;

c) Penggunaan/Penerapan, merupakan kemampuan menggunakan generalisasi atau abstraksi lainnya yang sesuai dalam situasi konkret dan atausituasi baru. Siswa dituntut memiliki kemampuan untuk menyeleksi atau memilih generalisasi/abstraksi tertentu secara tepat untuk diterapkan dalam suatu situasi baru dan menerapkannya secara benar;

d) Analisis, merupakan kemampuan menjabarkan isi pelajaran ke bagian-bagian yang menjadi unsur pokok. Siswa diminta untuk menganalisis hubungan atau situasi yang kompleks atau konsepkonsep dasar;

e) Sintesis, merupakan kemampuan menggabungkan unsur-unsur pokok ke dalam struktur yang baru. Dalam sintesis siswa diminta untuk melakukan generalisasi;

f) Evaluasi, merupakan kemampuan untuk menerapkan pengetahuan dan kemampuan yang telah dimiliki untuk menilai suatu kasus.

Tujuan ranah afektif berhubungan dengan hierarki perhatian, sikap, penghargaan, nilai, perasaan dan emosi. Taksonomi tujuan ranah afektif sebagai berikut:

a) Menerima, berupa perhatian terhadap simuasi secara pasif yang meningkat secara lebih aktif. Siswa diminta menunjukkan kesadaran, kesediaan untuk menerima dan perhatian terkontrol/terpilih;

b) Merespons, merupakan kesempatan untuk menanggapi stimulan dan merasa terukat serta secara aktif memperhatikan. Siswa diminta untuk menunjukkan persetujuan, kesediaan dan kepuasan dalam merespons;

c) Menilai, merupakan kemampuan menilai gejala atau kegiatan sehingga dengan sengaja merespon lebih lanjut untuk mencari jalan bagaimana dapat mengambil bagian atas apa yang terjadi. 
Siswa dituntut menunjukkan penerimaan terhadap nilai, kesuakaran terhadap nilai, dan ketertarikan terhadap nilai;

d) Mengorganisasi, merupakan kemampuan untuk membentuk suatu sistem nilai bagi dirinya berdasarkan nilai-nilai yang dipercaya. Siswa diminta untuk mengorganisasi nilai-nilai ke suatu organisasi ynag ebih besar.

e) Karakterisasi, merupakan kemampuan untuk mengkonseptualisasikan masing-masing nilai pada waktu merespons, dengan jalan mengidentifikasi karakteristik nilai atau membuat pertimbangan-pertimbangan. Siswa diminta untuk menunjukkan kemampuannya dalam menjelaskan, memberi batasandan mempertimbangkan nilai-nilai yang direspons;

Tujuan ranah psikomotorik berhubungan dengan keterampilan motoric, manipulasi benda atau kegiatan yang memerlukan koordinasi saraf dan koordinasi badan. Taksonomi ranah tujuan psikomotorik sebagai berikut:

a) Gerakan tubuh yang mencolok, merupakan kemampuan gerakan tubuh yang menekankan kepada kekuatan, kecepatan dan ketepatan tubuh yang mencolok. Siswa harus mampu menunjukkan gerakan yang menggunakan kekuatan tubuh, kecepatan tubuh, ketepatan posisi tubuhatau gerakan yang memerlukan kekuatan, kecepatan dan ketepatan gerak tubuh;

b) Ketepatan gerakan yang dikoordinasikan, merupakan keterampilan yang berhubungan dengan urutan atau pola dari gerakan yang dikoordinasikan biasanya berhubungan dengan gerakan mata, telinga dan badan. Siswa harus mampu menunjukkan gerakan-gerakan berdasarkan gerakan yang dicontohkandan/atau gerakan yang diperintahkan secara lisan;

c) Perangkat komunikais nonverbal, merupakan kemampuan mengadakan komunikasi tanpa kata. Siswa diminta untuk menunjukkan kemampuan berkomunikasi menggunakan bantuan gerakan tubuh dengan atau tanpa menggunakan alat bantu. 
Komunikasi dilakukan dengan benar-benar tidak menggunakan bantuan kemampuan verbal;

d) Kemampuan berbicara, merupakan kemampuan yang berhubungan dengan komunikasi secara lisan. Siswa harus mempu menunjukkan kemahirannya memilih dan menggunakan kata atau kalimat sehingga informasi, ide atau yang dikominikasikannya dapat diterima secara mudah oleh pendengarnya.

Harrow (1972) mengatakan penetuan kriteria untuk mengukur keterampilan siswa harus dilakukan dalam jangkan waktu 30 menit. Kurang dari waktu tersebut diperkirakan penilai belum dapat menangkap gambaran tentang pola keterampilan yang mencerminkan kemampuan siswa.

Tiga ranah tujuan yang menjdi sasaran evaluasi harus dijabarkan dulu ke dalam tujuan instruksional. Adapun tujuan instruksional sendiri terjabar menjadi Tujuan Instruksional Umum (TIU) dan Tujuan Instruksional Khusus (TIK). Untuk mengevaluasi yang terutama diperhatikan adalah ranah-ranah yang terkandung dalam rumusan TIK. Ranah-ranah yang terdapat dalam TIK inilah yang kemudian diukur dan dinilai untuk memperoleh kesimpulan hasil evaluasi yakni berupa nilai.

\section{PROSEDUR EVALUASI HASIL BELAJAR}

Evaluasi hasil belajar merupakan suatu proses yang sistematis. Tahapan prosedur evaluasi hasil belajar yang perlu dilalui seorang menilai meliputi: persiapan, penyusunanan alat ukur, pelaksanaan pengukur, pengelolaan hasil pengukuran, penafsiran hasil pengukuran, pelaporan dan penggunaan hasil evaluasi. Berikut ini merupakan penjelasan dari masing- masing tahapan prosedur evaluasi hasil belajar.

\section{Persiapan}

Evaluasi merupakan suatu tindakan kependidikan selalu diawali dengan perencanaan atau persiapan. Pada tahapan persiapan ini terdapat tiga kegiatan yang harus dilakukan evaluator, yakni: 
a) Menetapkan pertimbangan dan keputusan yang dibutuhkan,

b) Menggambarkan informasi yang dibutuhkan dan,

c) Menetapkan informasi yang sudah tersedia.

Menetapkan pertimbangan dan keputuskan yang akan dibuat, yanki suatu kegiatan yang dilakukan oleh seorang evaluator untuk mendeskripsikan pertimbangan dan keputusan yang sekiranya akan dibuat dari hasil evaluasi. Kegiatan ini dapat pula di sebut dengan langkah merumuskan tujuan, seperti dikemukakan oleh Nurkancana (1986:18-19). Seorang evaluator harus mampu menjabarkan sasaran dari evaluasi hasil belajar yang akan dilakukannya.

Pada tahapan menggambarkan informasi yang dibutuhkan evaluator mendeskrifsikan secara rinci segala informasi yang dibutuhkan untuk mencapai tujun atau sasaran evaluasi hasil belajar. Perincian informasi yang dibutuhkan tersebut merupakan aspek-aspek yang terkandung dalam sasaran evaluasi hasil belajar.

Langkah terakhir dari persiapan evaluasi hasil belajar adalah menetapkan informasi yang sudah tersedia pada sumbe-sumber informasi yang digunakan. Kegiatan ini dimaksudkan agar tidak terjadi pengulangan pengumpulan informasi pada tahapan berikutnya sekaligus memudahkan penyusunan instrumen evalusi hasil belajar baik tes maupun non tes.

\section{Penyusunan instrument evaluasi}

Instrumen evaluasi hasil belajar yang disebut juga alat penilaian yang akan digunakan, tergantung dari metode atau teknik evaluasi yang. Apabila menggunakan teknik tes maka alat penilaiannya berupa tes, sedangkan non tes alat penilaiannya berupa macam- macam alat penilaian non tes. Setelah jelas tentang teknik evaluasi hasil belajar dan penilaiannya, maka seorang evaluator dapat melaksanakan penyusunana alat penilaian. Berikut ini akan diuraikan prosedor penyusunan alat penilaian secara gari besar:

a) Menentukan bentuk tes yang akan disusun, yakni kegiatan yang dilaksanakan evaluator untuk memilih dan menentukan bentuk 
tes yang akan disusun dan digunakan sesuai kebutuhan. Bentuk tes ada dua yakni, tes objektif, dan tes esai (tes subjektif)

b) Membuat kisi-kisi butir soal yakni, kegiatan yang dilaksanakan evaluator untuk membuat suatu table yang memuat tentang perincian aspek isi dan aspek perilaku beserta imbangan atau proporsi yang dikehendakinya. Kiki-kisi butir soal atu tabel spesifikasi atau layout butir soal terdiri dari ruang lingkup isi pelajaran, proporsi jumlah intem dari tiap- tiap sub- isi pelajaran, aspek intelekual, dan bentuk soal.

c) Menulis butir soal, yakni kegiatan yang dilaksanakan evaluator setelah membuat kisi- kisi soal. Berdasarkan kisi- kisi soal inilah evaluator menulis soal dengan menggunakan bahasa yang sederhana, tidak mengendung penafsiran ganda, menyediakan petunjuk pengerjaan butir soal dan ditulis berdasarkan kaidah Bahasa Indonesia .

d) Empat hal yang perlu diperhatikan dalam penulisan soal seperti diuraikan di atas merupakan kaidah penulisan soal secara umum.

Kaidah-kaidah peulisan butir soal benar-salah meliputi:

- Meyakinkan sepenuhnya bahwah butir soal tersebut dapat dipastikan benar atau salah.

- Menghindari pernyataan negative

- Menghindari pernyataan berarti ganda.

- Menggunakan suatu bentuk yang tepat. Sedangan kaidah yang harus diperhatikan dalam penulisa soal pilihan ganda meliputi:

- Pokok soal (stem) yang merupakan permasalahan harus dirumuskan secara jelas.

- Perumusan pokok soal dan alternative jawaban hendakannya merupakan pertanyaan yang diperlukan saja.

- Untuk satu soal hanya ada satu jawaban yang benar atau paling benar.

- Pada pokok soal (stem) sedapat mungkin dihindarkan perumusan pernyataan yang bersifat negative. 
- Alternative jawaban (option) sebaikanya logis dan pengecoh harus berfungsi (menarik).

- Diusahakan tidak ada petunjuk untuk jawaban yang benar.

- Diusahakan agar pilihan jawaban homogen, baik dari segi isi maupun panjang pendeknya pernyataan.

- Di usahakan agar jawaban butir soal yang satu tidak bergantung dari jawaban butir soal yang lain.

- Dalam merakit soal diusahakan agar jawaban yang benar (kunci jawaban ) lataknya tersebar diantara a, b, c, dan/atau yang lain ditentukan secara acak, sehingga tidak terjadi pola jawaban tertentu. (Depdikbut, 1985: 21-28; Bloom, 1981: 196198).

Adapun kaidah penulisan bentuk soal menjodohkan meliputi:

- Meyakinkan bahwa antara premis dan pilihan yang dijodohkan kedussnys homogen.

- Munggunakan bentuk yang cocok.

- Dasar untuk menjodohkan setiap premis dan pilihan dibuat secara jelas.

Kaidah penulisan untuk bentuk soal melengkapi meliputi:

- Meyakinkan bahwa pernyataan dapat dijawab dengan kata atau penggalan kalimat yang mudah atau khusus, dan hanya ada satu jawaban yang benar.

- Menggunakan bentuk yang cocok.

- Menghindari pemberian petunjuk kearah jawaban yang benar.

- Menunjukan bagaimana seharusnya jabawan yang benar.

Untuk penulisan bentuk soal esai perlu diperhatikan kaidah sebagai beikut:

- Meyakinkan bahwa pertanyaan telah terarah.

- Jangan memberikan izin atau memerintah peserta ujian untuk memilih antara beberapa peryataan esai yang akan mereka jawab. 
- Terlebih dahulu memutuskan cara memberi skor pada pertanyaan esai.

e) Menata soal yakni, berupa pengelompokan butir-butir soal berdasarkan bentuk soal dan sekaligus melengkapi petunjuk pengerjaannya.

Prosedur yang dapat ditempuh untuk alat penialain non tes adalah sebagai berikut:

- Menetepkan bentuk non tes yang akan dilaksanakan, yakni kegiatan evaluator untuk menentukan bentuk non tes evaluasi hasil belajar yang akan dilaksanakan. Bentuk non tes evaluasi hasil belajar meliputi observasi, daftar cocok (check list), dan wawancara.

- Menetapkan aspek- aspek sasaran evaluari hasil belajar yang akan di nilai.

- Menulis alat penilaian non tes yang dibutuhkan sesuai dengan aspek- aspek sasaran evaluasi hasil belajar, yakni: lembar observsi, daftar cocok, dan pedoman atau lembar wawan cara.

\section{Pelaksanaan pengukuran}

Prosedur pelaksaan pengukuran adalah sebagai berikut:

a. Persiapan tempat pelaksaan pengukuran, yakni suatu kegiatan untuk mempersiapkan ruang yang memenuhi syarat- syarat pelaksaan pengukuran yang meliputi syarat penerangan, luas ruangan,dan tingkat kebisingan. Sedangkan persyaratan luas ruangan diperlukan agar ada jarak yang cukup antara siswa yang satu dengan yang lainnya, sehingga tak memancing terjadinya kecurangan.

b. Melancarkan pengukuran yakni kegiatan yang melaksanakan pengukuran terhadap siswa degan bentuk kegiatan sebagai berikut:

- Memberitahukan peraturan pelaksaan pengukuran,

- Membagikan lembar soal dan lembar jawaban, atau melakukan pengamatan, atau melakukan wawancara, atau membagikan daftar cocok, 
- Menguasai kedisiplinan siswa dalam mematuhi peraturan pelaksaan pengukuran, dan

- Mengumpulkan lembar jawaban dan lembar soal.

c. Menata dan mengadministrasikan lembar soal dan lembar jawaban siswa untuk memudahkan penskoran.

\section{Pengolahan Hasil Penilaian}

Data yang terkumpul dari penilaian dengan teknik tes akan berupa data kuantitatif, sedangkan teknik nontes akan menjaring data kualitatif maupun kuantitatif sekaligus. Mengolah data yang berhasil dikumpulkan melalui kegiatan penilaian inilah yang disebut kegiatan pengolahan hasil penilaian. Prosedur pelaksanaan pengolahan hasil penilaian adalah sebagai berikut.

1) Menskor, yakni kegiatan memberikan skor pada hasil penilaian yang dapat dicapai oleh siswa. Untuk menskor atau memberikab angka diperlukan tiga macam alat bantu yaitu: kunci jawaban, kunci skoring, dan pedoman pengangkatan. (arikunto, 1990:226)

2) Mengubah skor mentah menjadi skor standar, yakni kegitan evaluator menghitung untuk mengubah skor yang diperoleh siswa yang mengerjakan alat penilain disesuaikan dengan norma yang dipakai.

3) Mengkonversikan skor standard ke dalam nilai, yakni kegiatan akhir dari pengolahan hasil penilaian ang berupa pengubah skor skor kenilai, baik berupa huruf atau kata-kata.

\section{Penafsiran Hasil Penilaian}

Pengolahan hasil penilaian memberikan kepada kita sejumlah skor standard dan nilai bagi setiap siswa, maka kita harus mampu menafsirknanya, penafsiran terhadap hasil penilaian dapat kita bedakan menjadi dua, yakni penafsiran bersifat individual dan penafsiran yang bersifat klasikal.

Penafsiran hasil penilaian yang bersifst individual yakni penafsiran terhadap keadaan seorang siswa berdasarkan perolehan 
penilaian hasil belajarnya. Ada tga jenis penafsiran penilaian yang bersifat individual.

a. Penafsiran tentang tingkat kesiapan siswa untuk mengkuti pelajaran yang ebrikutnya, untuk naik kelas atau untuk lulus.

b. Penafsiran tentang kelemahan individual siswa pada sub-tes tertentu, pada satu mata pelajaran, atau pada keseluruhan mata pelajaran.

c. Penafsiran tentang kemajuan belajar individual siswa pada satu periode pembelajaran atau satu periode kelas, atau pada saut periode sekolah

\section{Pelaporan Dan Penggunaan Hasil Evaluasi}

Tahap akhir dari rosedur evaluasi hasil belajar adalah penyusunan/pembuatan laporan dan penggunaan hasil belajar. Pelaporan yang dimaksudkan untuk memberikan umpan balik kepada sEmua pihak yang terlibat dalam pembelajaran secara langsung maupun tidak langsung. Pihak-pihak yang perlu memperoleh laporan tentang hasil belajar siswa adalah: siswa, guru, orang tua siswa, dan pemakai lulusan. (Arikunto,1990:289)

\section{FUNGSI, TUJUAN DAN SASARAN EVALUASI PEMBELAJARAN}

Evaluasi pembelajaran merupakan proses untuk menentukan jasa, nilai atau manfaat kegiatan pembeajaran melalui kegiatan penilaian dan/atau pengukuran.

\section{Fungsi dan Tujuan Evaluasi Pembelajaran}

Tujuan utama evaluasi pembelajran adalah sejumlah informasi atau data tentang jasa, nilai atau manfaat kegiatan pembelajaran. Informasi inilah yang difungsikan untuk pengembangan pembelajaran dan akreditasi.

Fungsi dan tujuan evaluasi pembelajaran untuk pengembangan, maka evaluasi pembelajran sedang menjalankan fungsi formatif yaitu hasil yang diperoleh dari kegiatan evaluasi diarahkan untuk memperbaiki bagian tertentu atau sebagian bear kurikulum (pembelajran) yang sedang dikembangkan (Hassan,1998:39). 
Fungsi dan tujuan evaluasi pembelajran untuk Akreditasi. Akreditasi adalah suatu penilaian yang dilakukan oleh pemerintah terhadap sekolah swasta untuk menentukan peringkat pengakuan pemerintah terhadap sekolah tersebut. Akreditasi ditetapkan atau diputuskan setelah dilaksanakan evaluasi terlebih dahulu terhadap lembaga pendidikan baik TK, SD, SLTP, SLTA swasta maupun perguruan tinggi swasta

\section{Sasaran Evaluasi Pembelajaran}

Sasaran evaluasi pembelajaran adalah aspek-aspek yang terkandung dalam kegiatan pembelajaran. Dengan demikian sasaran evaluasi pembelajaran meliputi:tujuan pembelajaran, unsur dinamis pembelajaran, pelaksanaan pembelajaran dan kurikulum.

a) Tujuan Pembelajaran Hal-hal yang harus dievaluasi adalah tujaun pembelajaran meliputi : penjabaran tujuan pembelajaran, rumusan tujuan pengajaran dan unsur-unsur pengajaran. Penjabaran tujuan pembelajaran dimulai dari tujuan pengajaran tertinggi sampai tujuan pengajaran terendah, disebut hierarki tujuan. Tujuan pengajaran tertinggi adalah tujuan pendidikan nasional. Tujuan kelembagaan, tujuan kulikuler, tujuan umum pegajaran, dan terakhir tujuan khusus pengajaran.

b) Unsur Dinamis Pembelajaran, yang dimaksud unsur dinamis adalah sumber belajar atau komponen system instruksional yang terlibat dalam kegiatan pembelajaran. Sumber belajar meliputi: pesan, orang bahan, alat teknik, dan latar. Sumber belajar dibedakan menjadi dua jenis yaitu:

1) Sumber belajar yang dirancang (by design) yakni sumber belajar secara khusus telah dikembangkan sebagai komponen pembelajaran untuk memberikan kemudahan/fasilitas belajar yang terarah dan bersifat formal..

2) Sumber belajar karena dimanfaatkan (by utilization) yakni sumber belajar yang tidak secara khusus dirancang untuk keperluan pembelajaran namun dapat ditemukan, diterapkan dan digunakan untuk keperluan belajar. 
c) Sasaran Evaluasi Pembelajaran lainnya adalah pelaksanaan pembelajaran. Dalam hal ini pelaksanaan pembelajaran diartikan sebagai interaksi antara sumber belajar dengan siswa. Sasaran evaluasi pembeajaran dalam pelaksanaan pembelajaran secara lebih terperinci diantaranya adalah:

1) Kesesuaian pesan dengan tujuan pengajaran

2) Kesesuaian sekuensi penyajian pesan kepada siswa.

3) Kesesuaian bahan dan alat dengan pesan dan tujuan pengajaran.

4) Kemampuan guru menggunakan bahan dan alat dalam pembelajaran.

5) Kemampuan guru menggunakan teknik pembeajaran.

6) Kesesuaian teknik pepembelajaran dengan pesan dan tujuan pengajaran.

7) Interaksi siswa dengan siswa lainnya.

8) Interaksi guru dengan siswa.

d) Sasaran evaluasi pembelajran berikutnya adalah kurikulum. Dalam hal ini kurikulum dipandang sebagai rencana tertulis yakni seperangkat komponen pembelajran yang diuraikan secara tertulis pada bahan tercetak atau buku. Kurikulum sebagai sasaran evaluasi pembelajran akan meliputi:

1) Tersedianya sekaligus kelengkapanya komponen kurikulum.

2) Pemahaman terhadap prinsip-prinsip pengembangan dan pelaksanaan kurikulum.

3) Pemahaman terhadap tujuan kelembagaan atau tujuan instrusional sekolah

4) Pemahaman terhadap struktur program kurikulum

5) Pemahaman terhadap teknik pembelajaran

6) Pemahaman terhadap system evaluasi.

7) Pemahaman terhadap pembinaan guru.

8) Pemahaman terhadap bimbingan siswa. 


\section{E. PROSEDUR EVALUASI PEMBELAJARAN}

Prosedur evaluasi pembelajran terdiri dari lima tahapan, yakni penyusunan rancangan (design), penyusunan instrument, pengumpulan data, analisis data, dan penyusunan laporan evaluasi pembeajaran

\section{Penyusunan Rancangan}

Langkah-langkah kegiatan dalam penyusunan rancangan:

a) Menyusun latar belakang yang berisikan dasar pemikiran dan/atau rasional penyelenggaraan evaluasi.

b) Problematika yang berisikan rumusan permasalahan yang akan dicari jawabannya baik secara umum maupun secara terperinci.

c) Tujuan evaluasi merupakan rumuasan yangs sesuai dengan problematika evaluasi pembelajaran, yakni perumusan tujuan umum dan tujuan khusus.

d) Populasi dan sampel, yakni sejumlah komponen pembelajaran yang dikenai evaluasi dan/atau yang dimintai informasi dalam kegiatan evaluasi pembelajaran.

e) Instrument adalah semua jenis alat pengumpulan informasi yang diperlukan sesuai dengan teknik pengumpulan data yang diterapkan dalam evaluasi pembelajaran.

f) Teknik analisa data, yakni cara/teknik yang digunakan untuk menganalisis data yang sesuai dengan bentuk problematika dan jenis data.

\section{Penyusunan Instrumen}

Setelah seorang evaluator yang menyusun rancangan evaluasi pembelajaran, maka tahapan selanjutnya adalah penyusunan instrument evaluasi pembelajaran. Langkah-langkah penyusunan instrument adalah:

a) Merumuskan tujuan yang akan dicapai dengan instrument yang akan disusun.

b) Membuat kisi-kisi yang merencanakan tentang perincian variable dari jenis instrument yang digunakan untuk mengukur bagian variable yang bersangkutan. 
c) Membuat butir-butir instrument evaluasi pembelajaran yang dibuat berdasarkan kisi-kisi.

d) Menyunting instrument evaluasi pembelajaran yang meliputi: mengurutkan butir menurut sistematika yang dikehendaki evaluator untuk mempermudah pengolahan data, menulis petunjuk pengisian dan identitas serta yang lain, dan membuat pengantar pengisian instrumen.

\section{Pengumpulan Data}

Dalam pengumpulan data dapat diterapkan berbagai teknik pengumpulan data diantaranya adalah

a) Kuesioner, yakni seperangkat pertanyaan tertulis yang diberikan kepada seseorang untuk mendapatkan pendapat, keadaan, kesan yang ada pada diri orang tersebutmaupun diluar dirinya.

1) Mengujicobakan kuesioner kepada sejumlah orang yang memiliki karakteristik yang sama dengan yang akan mengisi angket.

2) Melancarkan penyebaran kuesioner kepada oaring yang dituju.

3) Mengumpulkan dan mengadministrasikan kuesioner.

4) Mengumpulkan data yang berhasil dikumpulkan.

b) Wawancara, yaitu teknik pengumpulan data yang menuntut adanya komunikasi langsung antar evaluator dengan sumber data. Langkah kegiatan yang dilakukan evaluator:

1) Menyusun pedoman wawancara atau daftar cocok (check-list) sesuai dengan data yang akan dikumpulakan.

2) Memahami tujuan dan petunjuk penggunaan wawancara.

3) Melaksanakan wawancara.

4) Menyusun sesegera mungkin jawaban hasil wawancara.

5) Mengolah data/informasi hasil wawancara.

c) Pengamatan, merupakan teknik pengumpulan data melalui kegiatan mengamati yang dilakukan oleh evaluator terhadap kegiatan pembelajaran. Langkah kegiatan yang dilakukan evaluator: 
1) Menyusun instrument pengamatan sesuai dengan informasi yang ingin dikumpulkan.

2) Meaksanakan pengamatan terhadap kegiatan pembelajaran dengan menggunakan instrument yang ada.

3) Mengolah data yang berhasil dikumpulkan.

d) Studi kasus adalah teknik pengumpulan data berdasarkan kasuskasus yang ada dan didokumentasikan. Langkah kegiatan yang dilakukan evaluator:

1) Menyusun instrument studi kasus.

2) Melaksanakan kegiatan lapangan.

3) Mengolah data yang diperoleh.

\section{Analisis Data}

Data atau informasi yang berhasil dikumpulkan selanjutnya diolah dan dianalisis. Data dapat diolah secara individual dan secara kelompok.

\section{Penyusunan Laporan.}

Setelah melakukan analisis data evaluator masih harus menyusun laporan tentang evaluasi pembelajaran yang telah mereka laksanakan. Dalam laporan evaluasi pembelajran harus berisikan pokok-pokok berikut

a) Tujuan Evaluasi, yang didahului dengan latar belakang dan alasan dilaksanakan evaluasi.

b) Problematika, berupa pertanyaan-pertanyaan yang telah dicari jawabannya melalui pengetahuan evalusi pembelajaran.

c) Lingkup dan metodologi evaluasi pembelajaran, yaitu unsurunsur yang dinilai dan hubungan antar variable, metode pengumpulan data, instrument pengumpulan data, teknik analisa data.

d) Pelaksanaan evaluasi pembelajaran, meliputi:

1) Siapa tim evaluator selengkapnya dan jika perlu dengan pembagian tanggung jawab.

2) Penjadwalan pelaksanaan evaluasi.

3) Kegiatan penyusunan laporan. 
Hasil evaluasi pembelajaran, yakni berisi tujuan pengajaran, tolak ukur, data yang diperoleh, dan dilengkapi dengan sejumlah informasi yang mendorong penemuan evaluasi pembelajaran sehinga engan mudah membuat keputusan dapat memahami tinkat keberhasilan pembelajaran 


\section{DAFTAR PUSTAKA}

\section{BUKU}

1. Akhiruddin, Rosnatang. 2017. Strategi Pembelajaran Sosiologi. Samudra Biru: Yogyakarta

2. - 2018. Strategi Pembelaran Sosiologi (Dilengkapi dengan 60 Model-model dan 20 Metode Pembelajaran). Rizky Artha Mulia: Makassar.

3. Akbar, Sa'dun. 2016. Instrumen Perangkat Pembelajaran. PT Remaja Rosdakarya: Bandung

4. Amiruddin. 2016. Perencanaan Pembelajaran (Konsep dan Implementasi). Parama Ilmu. Yogyakarta

5. Aunurrahman. 2016. Belajar dan Pembelajaran. Alfabeta: Bandung

6. Ase S. Muchyidin, 2001. Analisis Kebutuhan Sumber Informasi dan Sumber Belajar. Bahan Diklat E- Learning Propinsi Baten tahun 2001. Dinas Pendidikan Propinsi Banten

7. Andhika, Edi 2013. Pengaruh Model Pembelajaran Kooperatif tipe Inside Outside Circle Berbasis Media Audio Visual Animation Terhadap Hasil Belajar IPS. Jurnal Ilmiah. Universitas Pendidikan Ganesha.

8. Arsyad, S. 2011. Media Pembelajaran . Jakarta . Rajawali Pers.

9. Aunurahman. 2010. Belajar dan Pembelajaran. Bandung: Penerbit. Alfabeta Slameto.

10. Baharuddin, Wahyuni. 2010. Teori belajar dan Pembelajaran. Jogjakarta: Ar-Ruzz Media.

11. Djamarah, Syaiful Bahri. 1999. Psikologi Belajar. Jakarta: Rineka Cipta

12. Dimyati. 2013. Belajar dan Pembelajaran. Jakarta : Rineka Cipta

13. Daryanto \& Syaiful K. 2017. Pembelajaran ABAD 21. Gava Media: Yogyakarta

14. Darsono, Max, dkk. 2000. Belajar dan Pembelajaran. Semarang: IKIP Semarang Press. 
15. Fathurrohman, Pupuh dan Sutikno, Sobry. 2007. Strategi Belajar Mengajar melalui Penanaman Konsep Umum \& Konsep Islam. Cet. II, Bandung: Refika Aditama.

16. Gerlach S. Vernon \& Donald P. Ely, 1971, Teaching \& Media : A Systematic Approach. New Jersey: Prentice hal- Company.

17. Gulö, W. 2002. Strategi Belajar Mengajar. Jakarta: Grasindo.

18. German. 2013. Teori-Teori Pembelajaran. Wikibooks.org.

19. Hamzah, Uno. Nurdin, M. 2014. Belajar dengan Pendekatan PAILKEM. PT Bumi Aksara. Jakarta

20. Hariyanti \& Suyono. 2014. Belajar dan Pembelajaran (Teori dan Konsep Dasar). PT Remaja Rosdakarya: Bandung

21. Hayati Sri. 2017. Belajar dan Pembelajaran Berbasis cooperative Learning. Magelang: Graha Cendeka.

22. Hamalik, O. 2007. Kurikulum dan Pembelajaran. Jakarta: PT Bumi Aksara.

23. Knight, George R. 1982. Issues and Alternatives in Educational Philosphy. Cet. XII, Michigan: Andrews University Press.

24. Kuswana, Sunaryo, W. Dr. 2013. Taksonomi Berpikir. PT Remaja Rosdakarya: Bandung

25. Lefudin.2017. Belajar dan Pembelajaran. Yogyakarta:CV Budi Utama.

26. Naim, Ngainun dan Patoni, Achmad. 2007. Materi Penyusunan Desain Pembelajaran Pendidikan Agama Islam (MPDP-PAI). Yogyakarta: Pustaka Pelajar.

27. Riyanto, Yatim H. Dr. 2009. Paradigma Baru Pembelajaran (Sebagai Referensi bagi pendidik dalam implementasi pembelajaran yang efektif dan berkualitas). Kencana Prenadamedia Group: Jakarta.

28. Roziqin, Muhammad Zainur. 2007. Moral Pendidikan di Era Global; Pergeseran Pola Interkasi Guru-Murid di Era Global. Malang: Averroes Press.

29. Suryosubroto, B. 1997. Proses Belajar Mengajar di Sekolah. Jakarta: Rineka Cipta. 
30. Santoso S. Hamidjoyo dalam Deni Darmawan, 2001, Computer Mediated Communication dalam Meningkatkan Kualitas output SDm Divlat PT. Telkom. Bandung : Pascasarjana Unpad.

31. Sudirman, dkk, 1991, I Ilmu Pendidikan. Bandung : Remaja Rosdakarya.

32. Sanjaya, Wina. 2008. Pembelajaran dalam Implementasi Kurikulum Berbasis Kompetensi. Jakarta: Kencana.

33. Sardiman. 2011. Interaksi dan Motivasi Belajar-Mengajar. Jakarta: Rajawali Pers.

34. Sukmadinata, Nana Syaodih. 2007. Landasan Psikologi Proses Pendidikan. Cet. IV, Bandung: Remaja Rosdakarya.

35. Schunk Dale H. 2012. Teori-Teori Pembelajaran "Suatu Perspektif Pendidikan"., Boston: Pearson Education.

36. Tim PEKERTI-AA PPSP LPP. 2007. Panduan Evaluasi Pembelajaran. Surakarta : Universitas Sebelas Maret

37. Tilaar, H.A.R. 2002. Pendidikan. Kebudayaan, dan Masyarakat Madani Indonesia; Strategi Reformasi Pendidikan Nasional. Cet. III, Bandung: Remaja Rosdakarya.

38. Thobroni. M. 2017. Belajar dan Pembelajaran (Teori dan Prakti). Ar-Ruzz Media: Yogyakarta.

39. Trianto. 2009. Mendesain Model Pembelajaran Inovatif Progresif. Surabaya: Kecana.

40. Tatang. 2012. Ilmu Pendidikan. CV.Pustaka Setia: Bandung

41. Wahidmurni. Alfin, M. Ali, R. 2014. Evaluasi Pembelajaran (Kompetensi dan Praktik). Nuha Litera: Yogyakarta

42. Warsono \& Hariyanto. 2017. Pembelajaran Aktif (Teori dan Asesmen). PT Remaja Rosdakarya: Bandung

43. Yaumi M. 2013. Prinsip-Prinsip Desain Pembelajaran. Kencana Prenadamedia Group. Jakarta

44. Zainal, Arifin. 2014. Penelitian Pendidikan (Metode dan Paradigma Baru). PT Remaja Rosdakarya: Bandung 


\section{ONLINE}

1. Kingdom Knowledge. Prinsip-Prinsip Pembelajaran. Diperoleh 8 Juli 2019, Dari http://nhuynhuy1994.blogspot. com/2014/11/ prinsip-prinsip-pembelajaran_11.html

2. Https://ariesupriadi.wordpress.com/2011/11/03/masalah-masalah-belajar-dan-pembelajaran/

3. Http://biosbetter.blogspot.com/2016/04/masalah-masalah-dal-ampembelajaran-di.html

4. Http://yunifirwinda.blogspot.com/2015/06/masalah-masalahbelajar-dan-pembelajaran.html

5. Https://learnmine.blogspot.com/2017/02/makalah-kurikulumpendidikan.html

6. Isnaristiyana. Teori Belajar Deskriptif dan Perspektif Dll. Diperoleh 11 Juli 2019, dari https://isnaristiyana.wordpress.com/2012/10/25/teori-belajar/

7. Selalu Santi. Resume Teori Belajar Kontrukvistik. Diperoleh 12 Juli 2019, dari https://santisusanti1995.wordpress.com/ 2013/11/21/resume-teori-belajar-konstruktivisme/

8. Https://Www.Kajianpustaka.Com/2013/11/Model-Pembelajaran-Lingkaran-Dalam-Dan.Html

9. Http://Abdulgopuroke.Blogspot.Co.Id/2018/03/Model-Pembelajan-Ran-Ioc-Inside-Outside.Html diakses pada tanggal 26 Desember 2018.

10. Http://Srisulistr.Blog.Upi.Edu/2015/11/14/Belajar-Pembelajaran-Dan-Teori-Teori- Belajar/

11. Https://Wyw1d.Wordpress.Com/2009/11/10/Model-Pembelajaran-24-Inside-Outside- Circle-Spencer-Kagan/ (Widodo, Rachmat 2009)

12. Https://Bpa.Uii.Ac.Id/Sumber-Daya/Panduan-Pengisian-Rps/ (Di Akses 28 Agusuts 2018)

13. Watson, John Broadus. 1913. Psychology as the Behaviorist Views It, http://psychclassics.yorku. ca/Watson/views.htm ^\{http://en.wikibooks.org/wiki/\} http://, 


\section{BIODATA PENULIS}

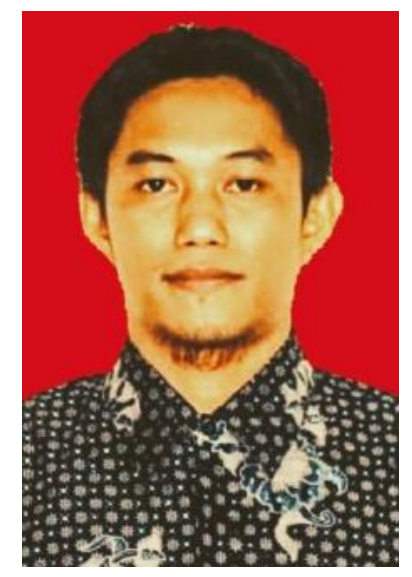

Akhiruddin adalah putra keenam dari pasangan Saleng dan $\mathrm{Hj}$. Nursiah, Lahir di Desa Bune 30 September 1985, Kecamatan Libureng Kabupaten Bone Provinsi Sulawesi Selatan. Penulis pernah menempuh Pendidikan (S1), di Jurusan Pendidikan Sosiologi Fakultas FKIP Universitas Muhammadiyah Makassar (2011), Magister Pendidikan (S2) Pada Jurusan Pendidikan IPS

Kekhususan Pendidikan Sosiologi Universitas Negeri Makassar (2014).

Penulis memiliki pengalaman mengajar di beberapa tempat seperti SMP PGRI 2 Makassar, SMP Tunas Bangsa Makassar, SMP Muhammadiyah 5 Mariso Makassar, Bimbingan Belajar (BIMBEL) QUANTA di SMA Atirah Makassar dan selain itu, penulis memilik pengalaman survei sosial kemasyarakatan seperti Jaringan Isu Publik (JIP), Citra Publik Indonesia (CPI) dan Citra Komunikasi Lingkar Survei Indonesia (CIKOM LSI). Penulis mulai bekerja Tahun 2014 hingga sekarang sebagai Dosen Tetap Yayasan (DTY) Pendidikan Islam Mega Rezky Makassar di Program Studi Sarjana Pendidikan Sosiologi (homebase) Fakultas Keguruan dan Ilmu Pendidikan (FKIP) Universitas Megarezky (UNIMERZ) dan mengajar mata kuliah beberapa seperti Belajar dan Pembelajaran, Strategi Pembelajaran Sosiologi, PPL I, PTK, Sosiologi Politik, Pengembangan Kurikulum dan Pengantar Pendidikan.

Penulis juga memiliki beberapa pengalaman penelitian diantaranya; Pengaruh Kemampuan Berinteraksi Siswa dalam Belajar Kelompok Terhadap Prestasi Belajar Sosiologi Kelas XI SMA Tunas Bangsa Makassar, Penerapan Model Pembelajaran DT2 (Dua Tinggal DUA Tamu) dalam Meningkatkan Hasil Belajar Sosiologi Kelas XI SMA Negeri 12 Makassar dan Pengembangan Perangkat 
Pembelajaran Berbasis Inside-Outside- Circle (IOC) Pada Mahasiswa Angkatan 2017 DI STKIP Mega Rezky Makassar.

Selain itu, juga memiliki publikasi ilmiah diantaranya yaitu Persepsi Masyarakat Terhadap Pernikahan Usia Muda (Studi Kasus Di Desa Mattirowalie Kecamatan Libureng Kabupaten Bone), Pengaruh Kemampuan Berinteraksi Belajar Siswa Terhadap Prestasi Belajar Sosiologi Kelas XI SMA Tunas Bangsa Makassar, Pengaruh Kemampuan Belajar Kelompok Siswa Terhadap Prestasi Belajar Sosiologi Siswa Kelas XI SMA Tunas Bangsa Makassar, Upaya Peningkatan Hasil Belajar Sosiologi Melalui Metode Diskusi Kelompok Siswa Kelas XI SMAN 12 Makassar, Penerapan Model Pembelajaran DT2 (Dua Tinggal Dua Tamu) dalam Meningkatkan Hasil Belajar Sosiologi Kelas XI SMA Negeri 12 Makassar, Application of Invisible Image Watermarking, Security Enhancement With USB Flash Disk As Key Using AES Algorithm, dan The Application of Problem Solving Reasoning (PSR) in Improving Students' Metacognitive at the Twelfth Grade Students of SMAN 19 Makassar.

Sedangkan Buku ajar diantaranya yaitu Strategi Pembelajaran Sosiologi diterbitkan Samudra Biru (2017) dan Strategi Pembelajaran Sosiologi (Dilengkapi dengan 60 Model \& 20 Metode Pembelajaran) diterbitkan Rizky Artha Mulia (2018). 


\section{BIODATA PENULIS}

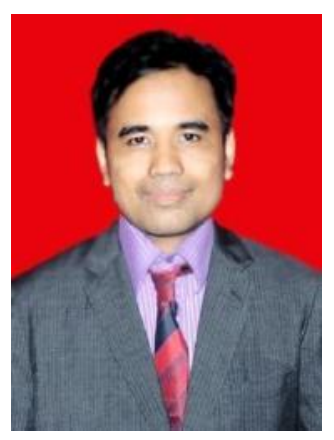

Sujarwo adalah putra kelima dari $\mathrm{H}$. Ibrahim dan $\mathrm{Hj}$. Siti Hamilah, lahir pada tanggal 03 Maret 1984 di Desa Ncera, Kabupaten Bima, Provinsi Nusa Tenggara Barat. Penulis belajar di MIS Ncera (1991 1997), kemudian melanjutkan studinya di MTS Ngali (1997 - 2000), dan melanjutkan studinya di SMA

Negeri 1 Raba (2000 - 2003). Selanjutnya melanjutkan studinya di Universitas Muhammadiyah Makassar (2003 - 2008). Kemudian penulis mendaftarkan studinya dan diterima di Program Pascasarjana di Universitas Negeri Makassar pada 2009-2011 di prodi pendidikan Bahasa Inggris.

Penulis memiliki pengalaman mengajar di beberapa tempat seperti mengajar Bahasa Inggris di LPKN Gowa pada 2006 - 2008, Yayasan Hj.Rini Widodo pada 2007 - 2009, Mengajar di Program PIKIH di Universitas Islam Negeri Makassar (UIN) Alauddin sejak 2010 hingga 2016. Penulis menjadi seorang guru bahasa Inggris di TK Amalia Insani pada tahun 2008-2015. Mengajar di STIKes Mega Rezky Makassar (Sekarang sudah menjadi Universitas Megarezky) sejak 2012 hingga sekarang. Kemudian memiliki homebase di Jurusan Pendidikan Bahasa Inggris STKIP Mega Rezky (Sekarang sudah menjadi Universitas Megarezky) sebagai Dosen Bahasa Inggris sejak 2014 hingga sekarang dan mengajar beberapa matakuliah seperti: Vocabulary, Curriculum and Material Development, Morphology, Semantics, Educational psychology, General English, ESP for Health (Nursing, Midwifery, Pharmacy, Medical Laboratory Technician), dan ESP for Sport di Universitas Megarezky.

Penulis juga mengikuti beberapa konferensi baik Konferensi Nasional maupun Internasional seperti Presenter di Prosiding Nasional Linguistik (SEMIOTIK) di Universitas Hasanuddin pada 2017, Presenter di Konferensi Internasional Pertama tentang Pendidikan Bahasa Inggris (ICONELE) Universitas Islam Negeri 
Alauddin Makassar pada tahun 2018. Selanjunya penulis mempublikasikan beberapa artikel dan jurnal Nasionan dan Internasional di antaranya: The Effect of the Use Grammar Maps In Improving Grammar Mastery (2015). Using Mnemonic Technique in Improving English Vocabulary Achievement of the Twelfth Grade Students of SMA Tut Wuri Handayani of Makassar (2017). Using Grammar Maps In Improving Grammar Mastery Of The Fourth Semester Students At Muhammadiyah University Of Makassar (2017). The Correlation Between Students' Vocabulary Mastery and Fluency in Speaking English at the First Semester Students of English Education Department of STKIP Mega Rezky Makassa (2017). The Implementation Of Hypnoteaching Technique In Enhancing Vocabulary Mastery (2018). Developing Reading Achievement Through Fiction Text (2018). Technique for Order of Preference by Similarity to Ideal Solution (TOPSIS) method for decision support system in top management (Jurnal Internasional, Index Scopus, Int. J. Eng. Technol, 2018). The Application of Problem Solving Reasoning (PSR) in Improving Students' Metacognitive at the Twelfth Grade Students of SMAN 19 Makassar (Jurnal Internasional, International Journal for Educational and Vocational Studies, 2019). Kemudian penulis mengarang buku berjudul: The Principle of English Vocabulary in Language Learning and Teaching (2018). 


\section{BIODATA PENULIS}

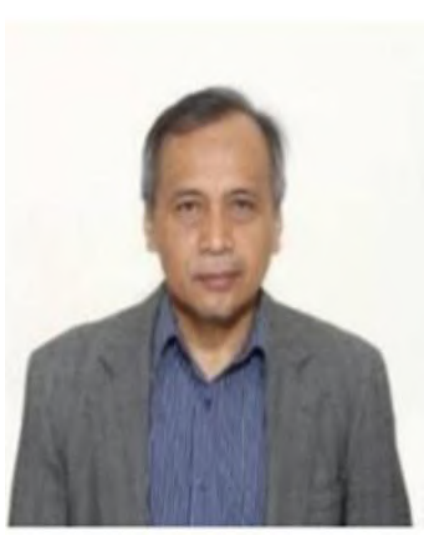

Haryanto Atmowardoyo adalah seorang Profesor pada program studi pendidikan Bahasa Inggris Universitas Negeri Makassar. Beliau dilahirkan pada tanggal 29 Oktober 1959 di Purbalingga, Jawa Tengah, Indonesia. Beliau menyelesaikan studinya di SD Galuh, Purbalingga pada tahun 1971, SMP Borromeus Purbalingga pada tahun 1974, dan SMA Negeri Purbalingga pada tahun 1977. Kemudian melanjutkan pendidikan S1 nya di IKIP Ujung Pandang pada tahun 1985, S2 di IKIP Malang pada tahun 1994 dan menyelesaikan S3 di IKIP Jakarta pada tahun 1999. Beliau ikut Academic research program mulai September 2009 sampai January 2010 di Ohio State University, Columbus, Ohio USA. Beliau sudah mempublikasikan Buku-Buku yang diterbitkan oleh Universitas Negeri Makassar Press di antaranya: Dasar - Dasar Penulisan, Isu Pendidikan Bahasa, Proposal Penelitian (2008), Publikasi Kerjasama dengan Sukandar Rumidi di Universitas Gajah Mada (UGM) yang dipublikasikan oleh Gajah Mada Press (2008), dan Metodologi Penelitian Kualitatif, Teori dan Dasar (2008) yang di publikasikan oleh Universitas Negeri Makassar. Juga beberapa artikel yang sudah dipublikasikan baik pada kora, jurnal online atau jurnal ilmiah, Cara Mudah Belajar Bahasa Inggris, Fleksibilitas Lokalisasi Pengajaran Bahasa Inggris, dan Perlukah Revolusi Pengajaran Bahasa Inggris yang di publikasikan di Fajar dan Pedoman Rakyat pada tahun 1994. Analisis Kritis terhadap Guru dalam Pembuatan Tes (Performance 1995), Laboratorium Bahasa Multimedia dan Fungsinya dalam Dalam Pembelajaran Bahasa Asing (2015, Pendidikan Network), Peranan Pendidikan, Universitas Jember (2017), Kajian Tentang Pembelajaran Bahasa Inggris yang Berhasil (Humaniora, UNHAS), (2007), Kecocokan Ketentuan Komunikasi pada Laboratorium Bahasa Multimedia (2008, Pendidikan Network). 
Haryanto Atmowardoyo telah mempersentasikan beberapa karyanya pada konferensi Internasional, seperti: Kesalahan Tatabahasa pada Pembelajaran Menulis Bahasa Asing pada Pelajar Indonesia (Jakarta, Konferensi Tahunan, Universitas Atmajaya pada Bulan Mei 2007), Metode Penelitian pada pembelajaran TEFL untuk Jurnal Internasional (Hanoi, Vietnam, Agustus 2010, Konferensi kedelapan ASIA TEFL, Agustus 2010 dan Penelitian Kualitatif pada Pembelajaran TEFL, (Makassar, Konferensi ICCOLE kedua 2010). 


\section{BIODATA PENULIS}

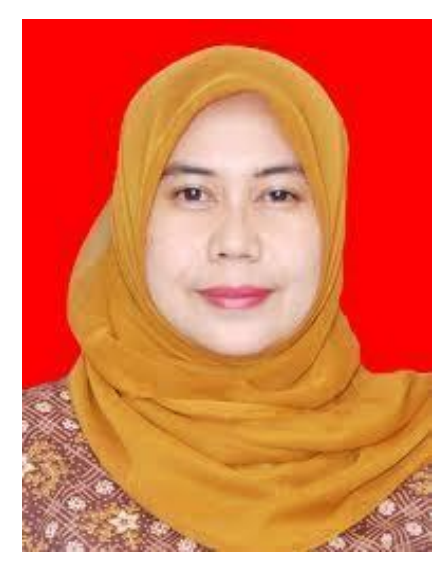

Dr. Nurhikmah H.,S.Pd.,M.Si. meraih gelar sarjana diprogram studi kurikulum dan teknologi pendidikan fakultas ilmu pendidikan institut keguruan dan ilmu pendidikan ujungpandang tahun 1996, meraih gelar magister di program studi sosiologi program pascasarjana universitas hasanuddin tahun 2002. Sejak tahun 2003 mengabdikan diri di UNM dan menjadi CPNS

2005 selanjutnya PNS tahun 2006 sebagai dosen tetap di prodi teknologi pendidikan S1 FIP UNM. Ditahun yang sama melanjutkan pendidikan di program pascasarjana Universitas Negeri Malang Program Studi Teknologi Pembelajaran dan meraih gelar Doktor di tahun 2011. Menjabat sebagai Kepala Laboratorium Teknologi Pendidikan S1 FIP UNM pada tahun 2011, menjabat sebagai sekretaris Program studi Teknologi pendidikan S1 pada tahun 2011 sampai 2016, menjabat sebagai ketua penjamin mutu pascasarjana UNM 2016 sampai 2017, dan ketua program studi magister teknologi pendidikan S2 Program pascasarjana Universitas Negeri Makassar pada tahun 2017 sampai saat ini. 